PATRICK LEMOS CACICEDO

\title{
PENA E FUNCIONALISMO SISTÊMICO: UMA ANÁLISE CRÍTICA DA PREVENÇÃO GERAL POSITIVA
}

\author{
Dissertação de Mestrado
}

Orientadora: Professora Associada Ana Elisa Liberatore Silva Bechara

UNIVERSIDADE DE SÃO PAULO

FACULDADE DE DIREITO

São Paulo-SP

2014 
PATRICK LEMOS CACICEDO

PENA E FUNCIONALISMO SISTÊMICO: UMA ANÁLISE CRÍTICA DA PREVENÇÃO GERAL POSITIVA

Dissertação apresentada à Banca Examinadora do Programa de Pós-graduação em Direito, da Faculdade de Direito da Universidade de São Paulo, como exigência parcial para obtenção do Título de Mestre em Direito, na área de concentração Direito Penal, Medicina Forense e Criminologia, sob orientação da Profa. Associada Ana Elisa Liberatore Silva Bechara.

UNIVERSIDADE DE SÃO PAULO

FACULDADE DE DIREITO

São Paulo-SP

2014 
Pena e funcionalismo sistêmico: uma análise crítica da prevenção geral positiva / Patrick Lemos Cacicedo; orientadora Ana Elisa Liberatore Silva Bechara -- São Paulo, 2014.

179

Dissertação (Mestrado - Programa de Pós-Graduação em Direito Penal, Medicina Forense e Criminologia) Faculdade de Direito, Universidade de São Paulo, 2014 .

1. direito penal. 2. teoria da pena. 3. teoria crítica. 4. funcionalismo. 5. prevenção geral orient. II. Título. 
PATRICK LEMOS CACICEDO

\section{PENA E FUNCIONALISMO SISTÊMICO: UMA ANÁLISE CRÍTICA DA PREVENÇÃO GERAL POSITIVA}

Dissertação apresentada à Banca Examinadora do Programa de Pós-graduação em Direito, da Faculdade de Direito da Universidade de São Paulo, como exigência parcial para obtenção do Título de Mestre em Direito, na área de concentração Direito Penal, Medicina Forense e Criminologia, sob orientação da Profa. Associada Ana Elisa Liberatore Silva Bechara.

BANCA EXAMINADORA

Presidenta:

Profa. Associada Ana Elisa Liberatore Silva Bechara

$1^{\circ}$ Examinador (a):

$2^{\circ}$ Examinador (a): 
À Gabi, com o maior amor do mundo. 


\section{AGRADECIMENTOS}

À Professora Ana Elisa Liberatore Silva Bechara, pela confiança e pelo ensinamento ao longo da orientação, que ultrapassou a barreira das ciências criminais para me apresentar uma práxis democrática de docência e me mostrar que mesmo diante das misérias do sistema penal não podemos perder a ternura.

Ao Professor Juarez Tavares, pela disponibilidade e contribuições no Exame de Qualificação, e por me incentivar desde o primeiro ano da graduação a ser um intransigente defensor da liberdade.

Ao Professor Sérgio Salomão Shecaira, pelas valiosas e estimulantes contribuições no Exame de Qualificação.

Aos amigos e defensores públicos Rafael Folador Strano e Thiago Pedro Pagliuca Santos, pelo constante debate durante toda a pesquisa e pela dedicada leitura deste trabalho.

Aos amigos e defensores públicos Bruno Shimizu, Bruno Girade Parise e Verônica dos Santos Sionti, pelos debates e combates diários diante do doloroso encarceramento em massa da pobreza.

Ao irmão paulista Caio Jesus Granduque José, por me ensinar que o absurdo do sistema penal não é direito, mas diante dele sempre deve permanecer acesa a chama da revolta.

À toda equipe do combativo e divertido Núcleo Especializado de Situação Carcerária da Defensoria Pública de São Paulo.

Aos amigos da pós-graduação Rodrigo José Fuziger e Alexandre Kassama, pela parceria durante o período de pesquisa.

Ao amigo Fernando Ponçano, pela estadia e debates em Barcelona.

À minha mãe Antonia, meu pai Francisco (in memoriam) e meus irmãos Thiago e Nathalia, pelo ambiente rigoroso e animado de estímulo ao estudo em casa.

À Gabi, exemplo de bondade e solidariedade, que, diante das privações provocadas pela pesquisa, me incentivou amorosamente em todos os momentos e tornou tudo possível. 
“Não há justiça se há sofrer Não há justiça se há temor E se a gente sempre se curvar" (Douglas Germano/Metá Metá, Obá Iná) 


\section{RESUMO}

O presente trabalho tem por objetivo analisar criticamente a teoria da prevenção geral positiva da pena construída por Günther Jakobs. Nesse passo, após uma digressão sobre a crise das teorias tradicionais da pena, analisa-se descritivamente o funcionalismo sociológico desde sua inauguração com Durkheim até a moderna versão sistêmica de Niklas Luhmann. Com base no funcionalismo sistêmico, Jakobs elabora a teoria da prevenção geral positiva em um percurso teórico que é apresentado em três diferentes fases. A segunda parte do trabalho analisa criticamente as bases sociológicas e jurídicofilosóficas do pensamento de Jakobs a partir de um viés da sociologia do conflito e da teoria crítica do direito. Por fim, além das críticas enunciadas pela doutrina penal, a teoria da prevenção geral positiva é confrontada com a realidade do processo de criminalização, de modo a revelar seu viés legitimador da seletividade do sistema penal, suas relações com o papel da mídia no incremento do autoritarismo penal, além do significado material da pena como imposição de sofrimento ao ser humano. $\mathrm{O}$ cotejo com a realidade brasileira termina por revelar a inadequação do discurso da pena de Jakobs para sociedades em processo de democratização cuja defesa da liberdade e da dignidade humana assumem um papel de prioritária importância.

Palavras chave: Teoria da pena - Funcionalismo sistêmico - prevenção geral positiva teoria crítica - criminologia crítica 


\begin{abstract}
This research aims to critically analyze Günther Jakobs' theory of the positive general prevention penalty. In this way, after a digression on the crisis of the traditional theories of punishment, the sociological functionalism is analyzed descriptively, from its beginning with Durkheim to the modern systemic version of Niklas Luhmann. Based on the systemic functionalism, Jakobs elaborates the theory of positive general prevention in a theoretical course divided into three different phases. The second part of this paper critically analyzes the sociological and legal-philosophical foundations of the ideas of Jakobs from a bias of sociology of conflict and critical theory of law. At last, in addition to the criticism made by the criminal doctrine, the positive general prevention theory is confronted with the reality of the criminalization process, in a way to reveal its legitimizing inclination to the selectivity of the criminal system, its relations with the media's role in increasing criminal authoritarianism, beyond the material meaning of the penalty how imposing suffering to the human being. The comparison with the Brazilian reality turns out to reveal the inadequacy of the penalty speech by Jakobs for societies under democratization process whose defense of freedom and human dignity assume a role of primary importance.
\end{abstract}

Keywords: Theory of the penalty - systemic functionalism - positive general prevention critical theory - critical criminology 


\section{SUMÁRIO}

INTRODUÇÃO

p. 11

\section{PARTE I - O FUNCIONALISMO PENAL SISTÊMICO E A CONSTRUÇÃO DA PREVENÇÃO GERAL POSITIVA}

CAPÍTULO 1 - AS TEORIAS DA PENA E SUA CRISE.....................................p. 18

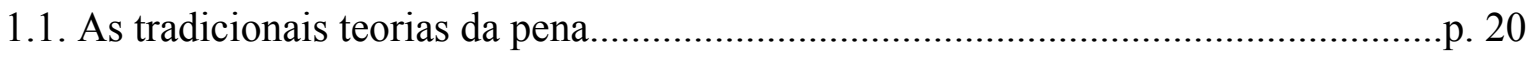

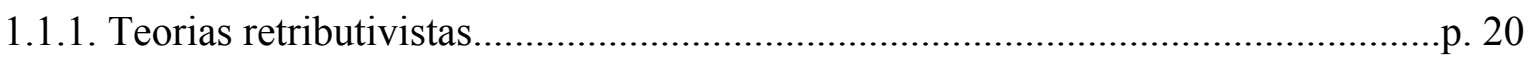

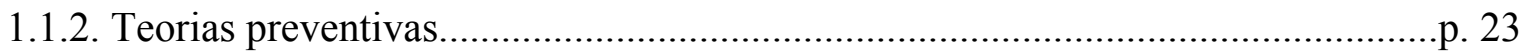

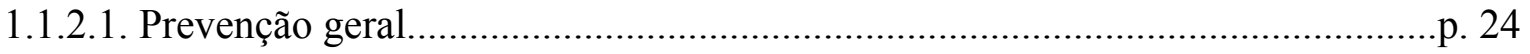

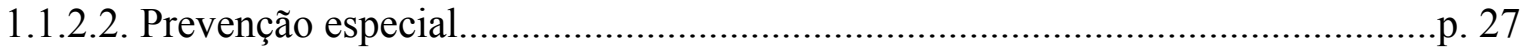

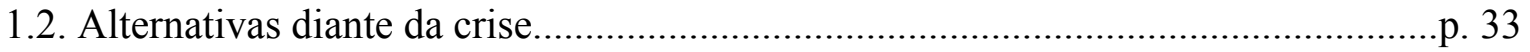

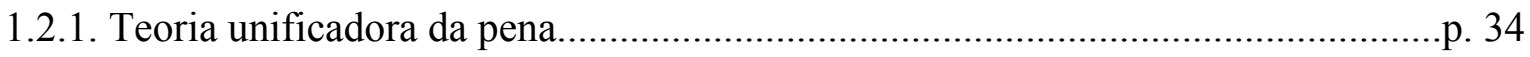

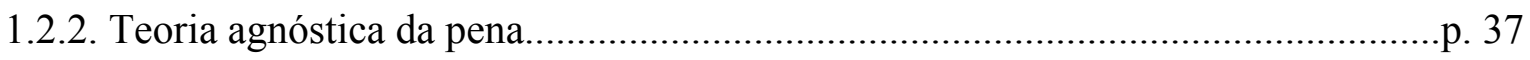

1.2.3. Teoria da prevenção geral positiva..................................................................p. 41

CAPÍTULO 2 - AS RAÍZES SOCIOLÓGICAS DO FUNCIONALISMO

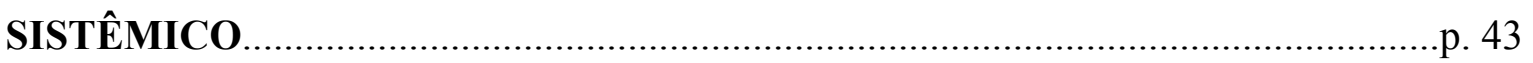

2.1. Émile Durkheim e a fundação do funcionalismo...................................................p. 43

2.1.1. O positivismo e as origens da sociologia ..........................................................p. 43

2.1.2. Émile Durkheim e o funcionalismo na sociologia...............................................p. 47

2.1.3. Émile Durkheim e o direito penal.....................................................................p. 52

2.2. Talcott Parsons e o desenvolvimento do funcionalismo..........................................p. 59

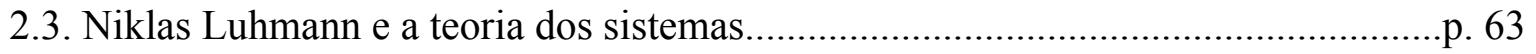

2.3.1. A influência do pensamento de Niklas Luhmann..................................................p. 63

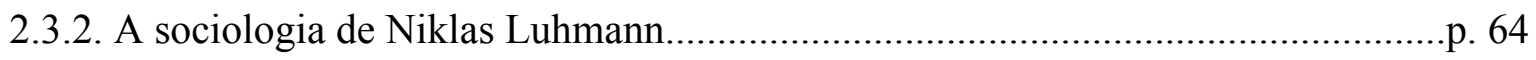

2.3.3. O direito em Niklas Luhmann..........................................................................p. 71

CAPÍtulo 3 - A TEORIA DA PREVENÇÃo GERAL POSITIVA NO PENSAMENTO DE GÜNTHER JAKOBS.........................................................p. 75

3.1. Hans Welzel e a prevenção geral positiva............................................................p. 75 
3.2. Günther Jakobs e a prevenção geral positiva.....

..p. 78

3.2.1. Culpabilidade e Prevenção: a primeira fase do pensamento de Günther Jakobs

3.2.2. Sociedade, norma e pessoa em uma teoria de um direito penal funcional: a segunda fase do pensamento de Günther Jakobs. p. 81

3.2.3. A pena estatal: a consolidação da teoria da pena de Günther Jakobs p. 85

3.3. O nascimento do direito penal do inimigo p. 88

3.4. A prevenção geral positiva limitadora de Winfried Hassemer e Claus Roxin. p. 90

3.5. Prevenção geral positiva em Günther Jakobs: síntese conclusiva. .p. 94

\section{PARTE II - A DESCONSTRUÇÃO DA TEORIA DA PREVENÇÃO GERAL POSITIVA DE GÜNTHER JAKOBS}

\section{CAPÍTULO 4 - ANÁLISE CRÍTICA DOS PRESSUPOSTOS TEÓRICOS DA PREVENÇÃO GERAL POSITIVA

4.1. Crítica aos fundamentos sociológicos. p. 103

4.1.1. Funcionalismo e conservação da ordem. .p. 104

4.1.2. Crítica ao funcionalismo sistêmico de Niklas Luhmann.. .p. 110

4.2. Crítica das bases jurídico-filosóficas do pensamento de Günther Jakobs p. 113

4.2.1. Direito e ausência de suporte material p. 113

4.2.2. Conceito de pessoa e suas consequências.

4.3. Bases para uma análise crítica do direito p. 123

4.4. Teoria crítica e o direito penal: a crítica.criminológica do direito penal. p. 129

\section{CAPÍTULO 5 - CRÍTICA DA TEORIA DA PREVENÇÃO GERAL POSITIVA DE GÜNTHER JAKOBS

5.1. Considerações gerais.

p. 135

5.2. Prevenção geral positiva e o processo de criminalização: a seletividade legitimada. p. 137

5.3. Prevenção geral positiva e processo comunicativo p. 143 
5.4. Prevenção geral positiva e o significado da pena: a dor como

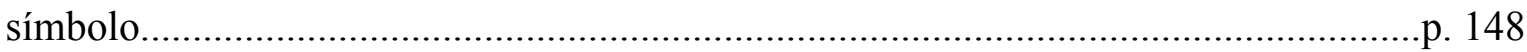

5.5. Prevenção geral positiva e a realidade brasileira. ...............................................p. 151

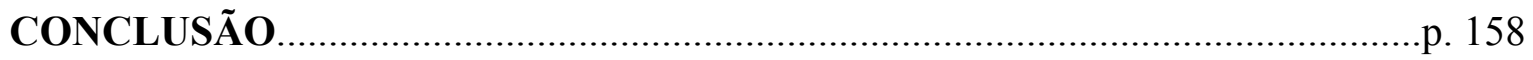

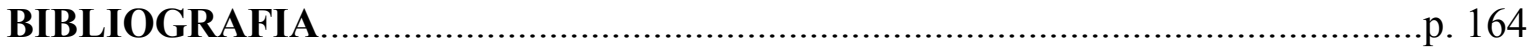




\section{INTRODUÇÃO}

David Garland inicia a introdução de sua obra sobre o castigo na sociedade moderna com a constatação de que a pena imposta aos transgressores representa um aspecto social particularmente inquietante e desalentador, pois como política social é uma decepção perpétua, já que suas metas nunca parecem ser cumpridas, e, além disso, está sempre socavada por crises e contradições de diversas índoles ${ }^{1}$.

De fato, a teoria da pena é um dos temas mais caros às ciências criminais, pois ao mesmo tempo em que possui importância central na tarefa de conferir legitimidade ao próprio poder de punir do Estado, não encontrou, ao longo dos séculos, uma construção suficientemente segura e sólida para justificar a imposição de penas em um regime democrático.

Tradicionalmente, a discussão em torno da legitimação do direito de aplicar sanções penais tem sido capitaneada pela tensão entre o paradigma das teorias absolutas ou retributivistas e o paradigma das teorias relativas ou preventivas da pena, dos quais surgiu, historicamente, o modelo das teorias unificadas ou ecléticas da pena.

Se as teorias preventivas de Feuerbach e Franz von Liszt foram suficientemente desenvolvidas, criticadas e reconstruídas, a teoria cujo desenvolvimento ainda passa por análise inacabada na contemporaneidade é aquela construída por Günther Jakobs, forjada a partir do funcionalismo sistêmico de Niklas Luhmann.

A presente dissertação abordará de forma crítica a teoria da prevenção geral positiva desenvolvida pelo funcionalismo penal sistêmico de Günther Jakobs. Por meio do recurso à sociologia, em especial ao funcionalismo sistêmico de Niklas Luhmann, o autor elabora um importante conjunto teórico que legitima e fundamenta o direito penal. Dentre os autores que se destacam na chamada escola funcionalista do direito penal, Jakobs é aquele que deixa explícita a influência do funcionalismo sociológico, de maneira que permite uma análise mais profunda das relações estabelecidas entre direito penal e sociologia.

\footnotetext{
${ }^{1}$ GARLAND, David. Castigo y Sociedad Moderna: un estudio de teoría social. 2. ed. Madrid: Sigo XXI Editores, 2006, p 13.
} 
Todavia, a despeito das inúmeras decorrências de sua construção teórica em todo o direito penal, especialmente na teoria do delito, o presente trabalho ficará delimitado ao âmbito da teoria da pena denominada de prevenção geral positiva. Embora existam outras versões da teoria da prevenção geral positiva, a presente dissertação abordará a vertente forjada por Jakobs. Assim, quando for mencionada apenas a expressão "prevenção geral positiva", trata-se da versão de Jakobs; as demais serão explicitamente adjetivadas, como, por exemplo, a prevenção geral positiva limitadora de Winfried Hassemer.

No estudo do direito penal, a teoria da pena apresenta uma marca distintiva fundamental em relação à teoria do delito e à teoria da lei penal, pois sua análise transcende de maneira significativa os limites da dogmática ${ }^{2}$. A penologia, por tratar dos fundamentos e da legitimidade do poder de punir do Estado, recebe necessariamente a influência das mais diversas ciências sociais e humanas, como a ciência política, a filosofia e a sociologia.

A despeito das influências filosóficas e jurídicas que se fazem notar em seus estudos sobre o direito penal, o elemento de originalidade da teoria da pena de Jakobs é a sua base sociológica, motivo pelo qual o trabalho se aterá primordialmente às raízes sociológicas de sua teoria. Com efeito, o funcionalismo sociológico de viés sistêmico confere à prevenção geral positiva desenvolvida por Jakobs uma gama de feições que engendram importantes controvérsias em torno dos fundamentos e consequências da sua teoria da pena.

O chamado funcionalismo penal é a principal base teórica dos penalistas contemporâneos. Desde a publicação de "Kriminalpolitik und Strafrechtssystem"33 por Claus Roxin, em 1970, o funcionalismo foi adotado como a fundamento do discurso jurídico penal, primeiramente na doutrina alemã e posteriormente em diversos países da cultura jurídica romano-germânica. Assim, o direito penal é apresentado a partir da função que cumpre no sistema social.

A teoria da pena ganha especial importância a partir de então, pois a doutrina penal passa a considerar que todos os institutos jurídico-penais devem ser interpretados segundo os parâmetros da política criminal, de modo que os conceitos dogmáticos passam a

\footnotetext{
${ }^{2}$ CARVALho, Salo de. Penas e medidas de segurança no direito penal brasileiro: fundamentos e aplicação judicial. São Paulo: Saraiva, 2013, p. 44.

${ }^{3}$ Cf. ROXIN, Claus. Política criminal e sistema jurídico-penal. Trad. Luís Greco. Rio de Janeiro: Renovar, 2002.
} 
depender substancialmente das finalidades atribuídas à pena e ao poder punitivo. Para os fins do presente trabalho, a pena em questão é a privativa de liberdade, em virtude de sua primazia como forma de punição do sistema penal contemporâneo.

A vertente sistêmica do funcionalismo também foi adotada pelo discurso jurídicopenal. Como mecanismo destinado a regular a vida em sociedade, o direito penal deve partir de um determinada compreensão desta sociedade a fim de que não se destine a regular aquilo que não conhece. Em outras palavras, é preciso conhecer o funcionamento daquela sociedade que se pretende regular.

Alessandro Baratta apontou que o florescimento do funcionalismo sistêmico proporcionou uma tentativa de solução aos problemas que tinham resposta insatisfatória no curso do desenvolvimento do direito penal ${ }^{4}$. Nesta seara, o coerente e sistemático aporte dogmático construído por Jakobs trouxe novos questionamentos ao direito penal e apontou soluções, ainda que discutíveis, para questões historicamente problemáticas no âmbito da ciência penal.

O ponto fundamental da teoria da prevenção geral positiva de enfoque sistêmico é a necessidade de garantir a vigência segura da norma. Para Jakobs, a pena tem lugar para exercitar a confiança na norma, a fidelidade ao direito e a aceitação das consequências no plano de uma sociedade harmônica e regida por expectativas de comportamento asseguradas pela norma.

Um dos aspectos centrais da teoria de Jakobs é a mudança do centro de gravidade do direito que passa da subjetividade do indivíduo e do mundo axiológico ao sistema e às expectativas institucionais, com o consequente afastamento de reflexões críticas no que se refere à funcionalidade do direito penal para o sistema. A pessoa cede lugar ao sistema e passa a ter um conceito normativo no plano comunicativo. É a comunicação que passa a definir os indivíduos como pessoas em função do papel social que representam.

Essa teorização sobre o conceito de pessoa permitiu a Jakobs construir a teoria extrema do direito penal do inimigo, culminando no máximo conservadorismo de sua produção teórica. Ao lado do direito penal do cidadão, figura o direito penal do inimigo que deve ser combatido de forma antecipada e sem garantias por sua periculosidade materializada na infidelidade ao direito.

\footnotetext{
${ }^{4}$ BARATTA, Alessandro. Integración-prevención: una "nueva" fundamentación de la pena dentro de la teoría sistémica. In: BARATTA, Alessandro. Criminología y sistema penal. Compilación in memoriam. Buenos Aires: B de F, 2006, p. 1.
} 
A influência do positivismo no campo jurídico fez com que historicamente as construções teórico-jurídicas tenham buscado dentro do próprio direito sua fundamentação, com pouco espaço para a pesquisa transdisciplinar. Todavia, no caso da teoria a ser abordada no presente trabalho, objetiva-se demonstrar que Jakobs busca na sociologia de Luhmann uma forma de abordar o direito de maneira ainda mais fechada em si mesmo.

O presente trabalho também pretende demonstrar como a adoção do funcionalismo sistêmico pelo direito penal reforça o distanciamento entre o direito penal, sua previsão normativa e a sua representação concreta, olvidando-se a complexidade do fenômeno jurídico, que se manifesta em condutas humanas inseridas em circunstâncias históricas permeadas de condicionantes econômicas, políticas, culturais e valorativas.

Para tanto, objetiva-se uma crítica dialética e radical da prevenção geral positiva, que vá de encontro às raízes sociológicas que emprestam a originalidade do pensamento de Jakobs, bem como que confronte seus objetivos e fundamentos com a manifestação concreta dos processos de criminalização.

A recepção da teoria sistêmica da prevenção geral positiva da pena no plano de uma realidade histórica pós-colonial, como a brasileira, também deve ser fruto de preocupação, pois sua adoção ou reprodução acrítica pode constituir verdadeiro conjunto teórico legitimador da pena como representação do poder punitivo causador de práticas violentas e violadoras de direitos humanos.

No presente trabalho, a teoria da prevenção geral positiva da pena será abordada em duas partes: a primeira trata da construção da teoria, desde seu surgimento no seio da crise das teorias da pena, até suas raízes na sociologia e o desenvolvimento impulsionado por Jakobs; a segunda parte pretende desconstruir a teoria da pena do autor alemão, tanto a partir dos seus pressupostos sociológicos e jurídico-filosóficos, quanto de seu confronto com o processo de criminalização levado a cabo pelo sistema penal. A primeira parte da dissertação abordará de forma descritiva a construção da teoria da prevenção geral positiva pelo funcionalismo sistêmico em três capítulos; a segunda consistirá em uma análise crítica que objetiva desconstruir a teoria da pena descrita e suas bases nos dois derradeiros capítulos.

O primeiro capítulo aborda o contexto teórico de nascimento da prevenção geral positiva no seio da crise da penologia moderna. Para tanto, são descritas e criticadas as teorias retributivistas de Kank e Hegel, bem como as teorias da prevenção geral negativa e 
da prevenção especial, que constituem os discursos mais difundidos sobre a pena na modernidade. Por fim, são abordadas as alternativas que surgiram diante da crise das teorias da pena, como a teoria unificadora, a teoria negativa ou agnóstica e o surgimento da prevenção geral positiva.

O segundo capítulo descreve as bases sociológicas do funcionalismo sistêmico com a fundação do funcionalismo por Émile Durkheim, sua evolução com Talcott Parsons e seu desenvolvimento sistêmico com Niklas Luhmann. Ainda neste capítulo serão abordadas as bases metodológicas da sociologia funcionalista dos autores, a forma como compreendem a existência e o funcionamento da sociedade, do fenômeno jurídico e do direito penal especificamente.

Já o terceiro capítulo descreve toda a formação da teoria da prevenção geral positiva por Jakobs, desde a apropriação da sociologia funcionalista até sua concepção de direito e, fundamentalmente, seu discurso legitimador da pena. Neste capítulo aborda-se, ainda, a evolução do pensamento do penalista alemão, a influência da filosofia de Hegel e do penalismo de Welzel, além da consolidação do seu conjunto teórico fundamentador da pena e sua diferenciação com a vertente limitadora da prevenção geral positiva. Por fim, descreve-se como a sua doutrina penal foi capaz de culminar na construção do chamado "Direito Penal do Inimigo".

No quarto capítulo, a crítica se funda nas bases sociológicas do funcionalismo sistêmico e na concepção do direito que sustenta o discurso legitimador do poder de punir em Jakobs. Na crítica sociológica são abordados desde a metodologia funcionalista, até sua concepção de sociedade baseada no consenso e o objetivo de manutenção da ordem. A crítica é realizada a partir da chamada sociologia crítica, principalmente por autores que desenvolveram uma análise sociológica a partir da referência marxista. Por outro lado, a teoria do direito que fundamenta a construção da teoria da prevenção geral positiva sistêmica é analisada a partir da crítica à função que o direito exerce na sociedade, além da própria metodologia utilizada e sua comparação com o positivismo kelseniano. A desconstrução do discurso em análise tem como base a chamada teoria crítica do direito, que no Brasil possui destacado desenvolvimento.

O quinto capítulo aborda a crítica da teoria da pena sistêmica sob o enfoque das ciências criminais. Após a exposição inicial das principais críticas que a teoria da prevenção geral positiva recebe no âmbito do direito penal, elabora-se um confronto da teoria da pena de Jakobs com a manifestação concreta do direito penal na realidade social. 
Assim, as inconsistências da teoria são expostas diante de seu cotejo com o processo de criminalização e sua estrutural seletividade, bem como pelo significado da teoria no aspecto comunicativo, no qual a relação dos meios de comunicação de massa com o sistema penal exerce um papel significativo para a desconstrução levada a efeito no capítulo. Por fim, a questão do significado material da pena e as peculiaridades da realidade brasileira terminam por desvelar o caráter conservador da teoria da prevenção geral positiva e os riscos que representa para sociedades que prezam pela democratização e pela liberdade humana. 
PARTE I - O FUNCIONALISMO PENAL SISTÊMICO E A CONSTRUÇÃO DA PREVENÇÃO GERAL POSITIVA 


\section{CAPÍTULO 1 - AS TEORIAS DA PENA E SUA CRISE}

SUMÁRIO: 1. As teorias da pena e sua crise - 1.1. As tradicionais teorias da pena - 1.1.1. Teorias retributivistas - 1.1.2. Teorias preventivas - 1.1.2.1. Prevenção geral - 1.1.2.2. Prevenção especial - 1.2. Alternativas diante da crise - 1.2.1. Teoria unificadora da pena -1 1.2.2. Teoria agnóstica da pena -1.2 .3 . Teoria da prevenção geral positiva.

É comum a afirmação de que o direito penal se diferencia dos demais ramos do direito pela natureza e intensidade da sanção que o caracteriza. Com efeito, a pena é a mais dura sanção existente no ordenamento jurídico e, desde sua origem, é objeto de estudos e análises por diversos campos do conhecimento humano, sem que isso signifique, todavia, a existência de um consenso sobre seu significado e características.

A aplicação de uma pena é a expressão do exercício de poder soberano do Estado, o poder de punir, que é justificado por uma série de discursos denominados "teorias da pena", que, ao longo da história, serviram de reivindicação, por vias diversas, da legitimidade do uso da força estatal como forma de punição de indivíduos submetidos ao seu controle. Nesse sentido, as teorias da pena constituem discursos de racionalização do ato de violência programado pelo poder político $^{5}$, de modo a conferir legitimidade ao poder punitivo dentro de uma ordem jurídica determinada. No Brasil, com a redução da política criminal à mera política penal ${ }^{6}$, o exercício do poder repressivo estatal necessita da legitimação discursiva oferecida pela teoria da pena.

As teorias da pena foram elaboradas para explicar o significado da punição, o motivo pelo qual o Estado se vale da pena, ou seja, a razão de ser deste fenômeno tão presente no cotidiano da sociedade moderna. A construção dos discursos sobre a pena tangencia necessariamente outros saberes para além do direito penal, como a ciência

\footnotetext{
${ }^{5}$ CARVALHO, Salo de. Penas e medidas de segurança no direito penal brasileiro, cit., p. 41.

${ }^{6}$ DIETER, Maurício Stegemann. O programa de política criminal brasileiro: funções declaradas e reais. Contribuições de Claus Offe para fundamentação da crítica criminológica à teoria jurídica das penas. Revista Eletrônica do CEJUR, v. 1, n. 2, Curitiba, 2007, p. 30.
} 
política, a filosofia, a sociologia e a criminologia, transcendendo a análise meramente normativa do fenômeno, tão comum nas demais teorizações sobre o direito penal, como a teoria da lei penal e a teoria do delito.

Na modernidade, os discursos sobre a pena formaram as grandes narrativas de legitimação do poder punitivo $^{7}$, que foram solidificadas em maior ou menor grau no pensamento penal e no senso comum como representação de um bem para a vida social. As doutrinas retributivistas e preventivas formaram o principal arcabouço teórico de sustentação das práticas punitivas levadas a efeito pelo poder estatal. Os discursos de justificação do castigo criminal na modernidade são reconhecidos como as já clássicas teorias da pena, que ainda são categoricamente predominantes no pensamento penal ocidental e encontram-se até mesmo positivadas no art. 59, do Código Penal Brasileiro ${ }^{8}$ e no art. $1^{\circ}$, da Lei de Execução Penal ${ }^{9}$.

Contudo, a despeito da consolidação e conservação das clássicas teorias da pena, as críticas que sofreram ao longo do tempo, especialmente quando confrontadas com a representação da pena na realidade concreta, demonstraram a fragilidade dos discursos e a necessidade de uma reflexão mais aguda sobre o fenômeno. Com efeito, seja por naturalizarem as consequências dolorosas e negativas da pena como realidade concreta ${ }^{10}$, seja pela escassa solidez fundamentadora dos discursos ${ }^{11}$, as teorias da pena e a própria prisão como prática punitiva da modernidade por excelência encontram-se imersas em uma constante crise.

\footnotetext{
${ }^{7}$ CARVALHO, Salo de. Penas e medidas de segurança no direito penal brasileiro, cit, p. 46.

8 “Art. 59 - O juiz, atendendo à culpabilidade, aos antecedentes, à conduta social, à personalidade do agente, aos motivos, às circunstâncias e consequências do crime, bem como ao comportamento da vítima, estabelecerá, conforme seja necessário e suficiente para reprovação e prevenção do crime."

9 “Art. $1^{\circ}$ - A execução penal tem por objetivo efetivar as disposições de sentença ou decisão criminal e proporcionar condições para a harmônica integração social do condenado e do internado."

${ }^{10}$ CARVALHO, Salo. op. cit., p. 41.

${ }^{11}$ ZAFFARONI, Eugenio Raúl; BATISTA, Nilo; ALAGIA, Alejandro; SLOKAR, Alejandro. Direito Penal Brasileiro I. Rio de Janeiro: Revan, 2003, p. 114.
} 


\section{1 - As tradicionais teorias da pena}

\subsection{1 - Teorias retributivistas}

Para a teoria retributivista, a pena representa uma justa retribuição pelo crime praticado. À violação do direito representada pelo delito deve corresponder uma pena para retribuir o mal causado e realizar a justiça. Fundada na ideia do livre-arbítrio, ou seja, na capacidade de escolha pela vontade humana entre o bem e o mal, a pena serviria para compensar a culpa daquele que escolheu a conduta indevida (o mal) qualificada como criminosa.

Com raízes tanto na religião, com a ideia de castigo divino ${ }^{12}$, quanto no moderno contratualismo do movimento iluminista, que entendia o crime como ruptura da obrigação contratual a merecer justa indenização representada pela pena ${ }^{13}$, a teoria da pena como retribuição desvincula-se de qualquer efeito social, motivo pelo qual também é qualificada como uma teoria absoluta em contraposição às teorias relativas, para as quais a pena deve ter uma utilidade social para além da mera vingança. Neste campo de análise, a teorização mais elaborada do retributivismo penal encontra-se em A Metafisica dos Costumes $(1797)^{14}$ de Immanuel Kant e na Filosofia do Direito $(1820)^{15}$ de Georg W. F. Hegel, obras fundamentais da filosofia do iluminismo.

O direito em Kant é considerado a expressão das obrigações morais dos indivíduos produzidas pela sociedade e exprime uma máxima segundo a qual todos devem atuar de modo que cada conduta valha como uma lei universal. Trata-se de um imperativo categórico, ou seja, um mandamento que representa uma ação em si mesma, objetivamente necessária, que não deve obedecer a nenhum fim específico. Da mesma forma, "a lei da

\footnotetext{
${ }^{12}$ BOZZA, Fábio da Silva. Teorias da pena: do discurso jurídico à crítica criminológica. Rio de Janeiro: Lumen Juris, 2013, p. 9.

${ }^{13}$ CARVALHO, Salo de. Penas e medidas de segurança no direito penal brasileiro, cit., p. 53.

${ }^{14}$ KANT, Immanuel. A metafísica dos costumes. Trad. Edson Bini. Bauru: EDIPRO, 2003.

${ }^{15}$ HEGEL, Georg Whilhelm Friedrich. Filosofia do direito. Trad. Paulo Meneses et al. São Leopoldo: Ed. UNISINOS, 2010.
} 
punição é um imperativo categórico" "16, uma exigência ética irrenunciável, que deve ser aplicada sempre que houver a prática de um crime, como imposição de um mal em virtude do mal representado pela violação ao dever jurídico de não praticar o delito ${ }^{17}$.

Por ser o homem um fim em si mesmo, Kant não considera eticamente justificável castigar alguém por razões utilitárias, mas apenas como uma retribuição pelo mal causado. A pena, portanto, não tem caráter preventivo e deve ser aplicada em qualquer hipótese, ainda que sem qualquer benefício pessoal ou social. De maneira coerente, uma vez que não se almeja qualquer outro fim que não seja a própria retribuição em si mesma, a medida da pena é defendida segundo a lei de talião, pois somente ela "é capaz de especificar definitivamente a qualidade e a quantidade da punição; todos os demais princípios são flutuantes e inadequados a uma sentença de pura e estrita justiça." ${ }^{\prime 18}$

Trata-se, portanto, de uma retribuição eminentemente ética, na qual a pena se justifica pelo valor moral da lei penal violada pelo indivíduo declarado culpado. Cumpre notar que a ideia da pena como um mal justo diante da injustiça do crime medida pela lei de talião encontra-se presente como influência cultural na psicologia popular de maneira significativa até os dias atuais ${ }^{19}$, fazendo parte daquilo que a criminologia denomina de every day theories ${ }^{20}$.

Já em Hegel, a retribuição abandona o caráter de uma necessidade ética para se configurar em uma imposição de caráter jurídico. Trata-se de uma forma de restabelecimento do direito violado pela conduta delitiva a partir do método dialético hegeliano: o crime representa a negação do direito, enquanto a pena significa a negação da negação do direito de maneira a restaurá-lo em uma síntese racional. A pena deixa de

\footnotetext{
${ }^{16}$ KANT, Immanuel, op. cit., p. 175.

${ }^{17} \mathrm{O}$ imperativo categórico da punição engendrava consequências extremas no pensamento kantiano, como se observa da clássica passagem da necessidade de punição mesmo em caso de dissolução da sociedade civil: "Mesmo se uma sociedade civil tivesse que ser dissolvida pelo assentimento de todos os seus membros (por exemplo, se um povo habitante de uma ilha decidisse separar-se e se dispersar pelo mundo), o último assassino restante na prisão teria, primeiro, que ser executado, de modo que cada um a ele fizesse o merecido por suas ações, e a culpa sanguinária não se vinculasse ao povo por ter negligenciado essa punição, uma vez que de outra maneira o povo pode ser considerado como colaborador nessa violação pública da justiça." KANT, Immanuel. A metafísica dos costumes, cit, p. 176.

${ }^{18}$ ibidem, p. 175.

${ }^{19}$ SANTOS, Juarez Cirino dos. Teoria da pena: fundamentos políticos e aplicação judicial. Curitiba: ICPC; Lumen Juris, 2005, p. 4.

${ }^{20}$ Cf. BARATTA, Alessandro. Criminologia crítica e crítica do direito penal: introdução à sociologia do direito penal. 3. ed. Tradução de Juarez Cirino dos Santos. Rio de Janeiro: Revan, 2002, p. 42; ANDRADE, Vera Regina Pereira de. A ilusão da segurança jurídica: do controle da violência à violência do controle penal. 2. ed. Porto Alegre: Livraria do Advogado Editora, 2003, p. 269.
} 
configurar um imperativo categórico para representar uma exigência da razão no restabelecimento do direito ${ }^{21}$.

A retribuição jurídica hegeliana igualmente prescinde de fins utilitaristas como a prevenção do delito, pois o homem pode servir de instrumento para obtenção de fins desejados pelo Estado. Seu caráter de justiça advém do fato de reafirmar o direito negado pela conduta considerada criminosa, e não por seu um mal imposto em virtude de outro mal, o que caracterizaria a pena como mera vingança. Trata-se, pois, de uma oposição racional à irracionalidade do fato representado no delito, configurando mesmo um direito do próprio infrator da normal penal.

As ideias do crime como violação da ordem jurídica, e não como produção de um mal ou violação de imperativo ético, e da pena como restituição da ordem jurídica violada encontram no debate contemporâneo uma nova leitura a partir da teoria penal de Günther Jakobs, que, como será exposto, confunde o conteúdo material do delito com a própria violação da norma penal e também trabalha com a ideia de pena como restabelecimento da ordem jurídica violada.

Em que pese o relevo das teorias absolutas na formulação de uma justificação racional para a pena, as ideias centrais deste conjunto filosófico sofreram severas críticas no âmbito das ciências penais, de modo que, contemporaneamente, restam isoladas posições que comungam de uma justificativa meramente retributivista da sanção penal no plano discursivo.

As teorias absolutas da pena sofreram críticas principalmente dos defensores das vertentes preventivas que não admitem que as sanções prescindam de fins sociais ${ }^{22}$, pois as penas deveriam ter legitimidade para orientar os sistemas punitivos a fim de, por exemplo, prevenir o delito e tutelar subsidiariamente bens jurídicos. Com efeito, a consolidação das teorias da prevenção geral negativa e especial positiva operaram um duro desgaste nas narrativas retributivistas ${ }^{23}$.

O fundamento na ideia do livre-arbítrio, considerada cientificamente como indemonstrável, bem como a ideia de que um mal pode suprimir outro mal realizando justiça ou restabelecendo o direito, fazem com que a teoria retributivista se torne aquilo

\footnotetext{
${ }^{21}$ HEGEL, Georg Whilhelm Friedrich. Filosofia do direito, cit..

${ }^{22}$ Cf. ROXIN, Claus. Derecho penal: parte general. Tomo I. Fundamentos. La estructura de la teoría del delito. Trad. Diego-Manuel Luzón Peña et al. 2. ed. Madrid: Civitas, 2003, p.84.

${ }^{23}$ CARVALHO, Salo. Penas e medidas de segurança no direito penal brasileiro, cit., p. 57.
} 
que Claus Roxin chamou de um mero ato de fé ${ }^{24}$, uma vez que a relação estabelecida entre o crime e o seu castigo como forma de retribuição não constitui um nexo de causalidade necessário em que o segundo mal (pena) compensará o primeiro (delito), o que somente poderia se verificar no plano abstrato de um idealismo.

Todavia, as críticas mais agudas ao modelo retributivista da pena residem no potencial autoritário que o referido discurso é capaz de legitimar ${ }^{25}$, especialmente pela rememoração de sistemas punitivos primitivos baseados na vingança e na lei de talião. Com efeito, em sociedades com predomínio de uma cultura punitivista e penalmente conservadoras, como a brasileira ${ }^{26}$, as teorias absolutas conferem relevante efeito intensificador da produção de dor por meio da aplicação da pena.

Por fim, como se retomará adiante, a estrutura seletiva do sistema penal não permite que se atribua à pena a afirmação da justiça ou reafirmação do direito, como almejam as teorias absolutas da pena, senão apenas a retribuição de alguns poucos casos selecionados no processo de criminalização.

\subsection{2 - Teorias preventivas}

As teorias preventivas da pena constituem o conjunto de discursos de maior amplitude e influência no âmbito da penologia contemporânea. A prevenção do delito representa o elo entre os diferentes discursos sobre a pena, a qual passa a ter necessariamente uma finalidade social, em nítida oposição às ideias meramente retributivistas, motivo pelo qual também são conhecidas como teorias relativas da pena. Neste aspecto, é importante frisar que, a despeito da importância histórica das teorias absolutas na construção de um discurso legitimador da pena e no desenvolvimento do

\footnotetext{
${ }^{24}$ ROXIN, Claus, op. cit., p.84.

${ }^{25}$ Cf. FERRAJOLI, Luigi. Direito e razão: teoria do garantismo penal. Trad. Ana Paula Zomer Sica, Fauzi Hassan Choukr, Juarez Tavares e Luiz Flávio Gomes. 2. ed. São Paulo: Editora Revista dos Tribunais, 2006, p. 240.

${ }^{26}$ Cf. PASTANA, Debora Regina. Justiça penal no Brasil contemporâneo: discurso democrático, prática autoritária. São Paulo: Ed. UNESP, 2010; BATISTA, Nilo. Política criminal com derramamento de sangue. Discursos Sediciosos: crime, direito e sociedade, Rio de Janeiro, v. 5/6, 1998.
} 
princípio da culpabilidade ${ }^{27}$, o debate contemporâneo sobre a punição gravita ao redor das teorias relativas.

No domínio das teorias relativas da pena, destacam-se dois grandes grupos que conferem a racionalização da punição por meio do discurso de prevenção do delito: o das chamadas teorias da prevenção geral, que pretendem que o alegado valor positivo da punição atue sobre as pessoas que não foram criminalizadas, vale dizer, sobre a sociedade em geral; e o das teorias da prevenção especial, que aspiram a prevenção do delito a partir dos efeitos positivos que a pena produziria sobre as pessoas criminalizadas e submetidas à punição pelo sistema de justiça criminal. Os dois grandes grupos de teorias preventivas não são estritamente homogêneos, pois possuem variações e tendências internas, mas que, para os fins do presente trabalho, podem ser descritas em linhas gerais de maneira não exaustiva.

\subsubsection{1 - Prevenção geral}

O ponto central da teoria da prevenção geral da pena é a influência desta na população em geral, naqueles que não foram submetidos à pena criminal no processo de criminalização. Surgiu e ganhou força por meio do modelo de dissuasão e, posteriormente, engendrou-se outra versão, chamada de positiva em oposição à negativa clássica dissuasória, que será analisada posteriormente no presente trabalho, uma vez que constitui seu objeto central.

A prevenção geral negativa é o principal discurso penal do liberalismo contratualista construído no seio do movimento iluminista. Suas bases são encontradas na obra do principal iluminista no que se refere à questão penal, Cesare Bonesana, o Marquês de Beccaria, que rompe com o retributivismo para difundir uma finalidade dissuasória da pena $^{28}$. Com base na teoria contratualista, o iluminista milanês apontou o fundamento do poder punitivo na cessão da liberdade individual em prol do poder soberano que garantiria

${ }^{27}$ Cf. CARVALHO, Salo. Penas e medidas de segurança no direito penal brasileiro, cit., p. 61.

${ }^{28}$ Cf. BECCARIA, Cesare Bonesana. Dos delitos e das penas. Trad. Lucia Guidicini e Alessandro Berti Contessa. São Paulo: Martins Fontes, 1997, p. 62. 
a ordem social em oposição à barbárie ${ }^{29}$. O exercício do poder punitivo, por conseguinte, não poderia ser levado a cabo senão para proporcionar um bem para o corpo social, o que se traduziria na prevenção dos delitos por meio da intimidação dos demais cidadãos. E tal objetivo só seria possível e legítimo se a pena aplicada àquele que rompeu o contrato social por meio da conduta criminosa observasse alguns parâmetros como a proporcionalidade, necessidade e culpabilidade. A utilidade social da pena seria o constrangimento da sociedade diante do exemplo da aplicação da pena, que faria com que seus membros não incidissem no mesmo equívoco.

Todavia, foi com Paul Johann Anselm Ritter von Feuerbach que a teoria da prevenção geral negativa ganhou corpo e densidade ${ }^{30}$. Para o autor alemão, a pena deve exercer um efeito psicológico de intimidação no corpo social para que não ocorra a prática de delitos. Segundo tal concepção, a pena deve dirigir-se unicamente ao conjunto da sociedade, mas não ao indivíduo efetivamente penalizado. Para o autor, o Estado só teria legitimidade para tutelar a liberdade, sem poder interferir, no entanto, em questões morais ou culturais próprias do indivíduo, com uma nítida rejeição de qualquer referencial correcionalista e a consequente separação do direito da moral.

Para Feuerbach, o caráter simbólico da pena responsável pelo efeito psicológico junto ao corpo da sociedade só é possível se o Estado leva a efeito a aplicação das penas a todos os fatos delituosos ocorridos, ou seja, para que a pena cumpra seu papel é necessária a certeza e a efetividade da punição diante dos crimes cometidos ${ }^{31}$. A intimidação que se pretende com a lei penal somente produzirá o efeito pretendido, portanto, com sua efetiva aplicação no mundo dos fatos, com a certeza da punição.

Conforme mencionado, a ideia da coação psicológica é até os dias atuais o mais forte discurso legitimador da pena, seja no âmbito acadêmico, seja no imaginário popular (every day theories). É, com efeito, a principal fonte argumentativa para a criminalização

\footnotetext{
${ }^{29}$ Nascem da mesma construção teórica as modernas ideias de garantia do cidadão frente ao poder punitivo estatal, como a proporcionalidade das penas e a proscrição da pena de morte. Cf. BECCARIA, Cesare Bonesana, op. cit., p. 91 e ss.

${ }^{30}$ Cf. FEUERBACH, Paul Johann Anselm Ritter von. Tratado de derecho penal. Trad. Eugenio Raúl Zaffaroni e Irma Hagemeier. Buenos Aires: Hammurabi, 2007, p. 52 e ss.

31 "I) O objetivo da cominação da pena na lei é a intimidação de todos, como possíveis protagonistas de lesões jurídicas. II) $\mathrm{O}$ objetivo de sua aplicação é o de dar fundamento efetivo à cominação legal, dado que sem a aplicação, a cominação restaria oca (seria ineficaz). Posto que a lei intimida a todos os cidadãos e a execução deve dar efetividade à lei, resulta que o objetivo mediato (ou final) da aplicação é, em qualquer caso, a intimidação dos cidadãos mediante a lei." FEUERBACH, Paul Johann Anselm Ritter von, op. cit., p. 53 , tradução livre.
} 
de condutas ou o agravamento da penalização daquelas já existentes, motivo pelo qual também recebe duras críticas das mais variadas vertentes teóricas.

No plano normativo, a principal crítica sofrida pela teoria da prevenção geral negativa desde seu nascedouro possui relação com a quebra do imperativo categórico kantiano segundo o qual o homem é um fim em si mesmo, pois a partir da teoria da coação psicológica o homem passa a servir como mero instrumento para atingir os fins do Estado, ou seja, deixa de ser um fim em si mesmo para constituir-se em meio para prevenção do delito. A prevenção geral negativa realizaria, então, um processo de coisificação do sujeito, que para realizar os fins preventivos no corpo social seria transformado em mero objeto de exemplaridade da pena.

Não bastassem os problemas éticos da crítica acima exposta, a refutação mais aguda da teoria da coação psicológica reside na sua potencialidade de legitimar modelos de direito penal máximo. Com efeito, se o exemplo da pena tem o positivo efeito de prevenir condutas criminosas, é consequência natural que a criminalização seja utilizada em larga escala para alcançar os objetivos propostos. Se a ameaça da pena atinge o fim da prevenção do delito, é inevitável que o recurso à criação de novos tipos penais e o aumento do rigor na punição dos já existentes seja uma prática fomentada e o direito penal perca sua declarada característica da ultima ratio.

Demais disso, o discurso da dissuasão pela ameaça da pena carece de maior verificação empírica, pois a lógica de seu discurso não realiza na realidade concreta a promessa de prevenção. Com efeito, no plano abstrato a teoria da prevenção geral negativa é aparentemente irrefutável: diante da ameaça da pena, os cidadãos valorariam as consequências da punição e racionalmente decidiriam pela prática do crime ou pela observância das normas jurídicas, bastando que as penas sejam duras o suficiente para que no cálculo entre os custos e os benefícios a observância do direito prevaleça. Todavia, a relação de causa e efeito entre a ameaça da pena e o não cometimento de crimes, baseada na ideia de livre-arbítrio, ignora a complexidade do fenômeno criminal e historicamente não restou comprovada no plano concreto ${ }^{32}$.

Ao ignorar a complexidade das relações sociais, a teoria da prevenção geral negativa identifica o poder punitivo com a totalidade da cultura, pois atribui à pena os

\footnotetext{
${ }^{32}$ Cf. CARVALHO, Salo. Penas e medidas de segurança no direito penal brasileiro, cit., p. 68.
} 
efeitos produzidos por toda a ética social em uma espécie de panpenalismo jurídico ${ }^{33}$. A complexidade do fenômeno criminal é reduzida a um discurso que promete aquilo que desde sua origem não foi capaz de cumprir.

Todavia, se o efeito proclamado não se mostrou efetivo, isso não impediu que a manutenção do discurso fosse uma das principais responsáveis, na prática, pelo endurecimento das leis penais e da sua imposição como forma de exemplo pelo Poder Judiciário $^{34}$ no Brasil. Os perigos da teoria da coação psicológica são retratados até mesmo por autores como Claus Roxin, que a adota de maneira matizada no plano de uma teoria unificadora da pena, ao apontar para os riscos de a teoria da prevenção geral negativa legitimar um verdadeiro mecanismo de terror estatal ${ }^{35}$.

Trata-se, pois, do discurso sobre a pena com maior capacidade de legitimação de um direito penal máximo, além de ser a teoria com maior aceitação doutrinária e no senso comum da sociedade. Sua inaptidão para fundamentar uma prática de garantia da liberdade no plano de um Estado Democrático de Direito ${ }^{36}$ tem no exemplo do Brasil contemporâneo, caracterizado pela inflação legislativa penal e pelo processo de encarceramento em massa, o maior símbolo do seu próprio fracasso como um discurso que possa engendrar qualquer potencial emancipador da pessoa humana diante da irracionalidade do poder punitivo estatal.

\subsubsection{2 - Prevenção especial}

O segundo discurso de grande influência na justificação da pena é a chamada teoria da prevenção especial, cuja característica central reside na defesa da produção dos efeitos

\footnotetext{
${ }^{33}$ ZAFFARONI, Eugenio Raúl; BATISTA, Nilo; ALAGIA, Alejandro; SLOKAR, Alejandro. Direito Penal Brasileiro I, cit., p. 118.

${ }^{34}$ ZAFFARONI, Eugenio Raúl; BATISTA, Nilo; ALAGIA, Alejandro; SLOKAR, Alejandro. Direito Penal Brasileiro I, cit., p.119.

${ }^{35}$ ROXIN, Claus. Problemas fundamentais de Direito Penal. 2. ed. Lisboa: Vega, 1998, p. 23.

${ }^{36}$ Cf. SHECAIRA, Sérgio Salomão; CORRÊA JUNIOR, Alceu. Teoria da pena: finalidades, direito positivo, jurisprudência e outros estudos de ciência criminal. São Paulo: Editora Revista dos Tribunais, 2002, p. 131.
} 
da pena sobre o indivíduo criminalizado, ao contrário dos defensores da teoria da prevenção geral, para quem os efeitos da pena devem incidir sobre a sociedade em geral. A principal vertente da prevenção especial é aquela qualificada como positiva, por observar na pena a função benéfica de melhoramento do sujeito criminalizado e, dessa forma, prevenir que o indivíduo volte a delinquir.

O discurso da segunda fase da modernidade penal $^{37}$, com grande influência ao longo do século XX, se materializou naquilo que Eugenio Raúl Zaffaroni, Nilo Batista, Alejandro Alagia e Alejandro Slokar chamam de ideologias re, consistentes na melhora do sujeito mediante ressocialização, reeducação, reinserção, repersonalização, reindividualização e/ou reincorporação ${ }^{38}$. Sob essa perspectiva, a pena passa a ser um bem para quem a sofre, tanto que se propõe até a modificação das nomenclaturas tradicionalmente utilizadas, substituindo expressões vinculadas ao punitivismo por eufemismos, tais como a aplicação de "medidas" ao invés de penas.

O positivismo criminológico foi a principal fonte teórica para a construção da teoria da prevenção especial positiva. O estudo criminológico empreendido pelos positivistas buscou por meio da pesquisa empírica descobrir as causas do comportamento criminoso com o propósito de solucionar o problema da criminalidade e ordenar o meio social. Para Cesare Lombroso o crime era um fenômeno biológico e não meramente jurídico, de modo que passou a estudar as características biológicas dos encarcerados para elaborar sua ideia central do "homem criminoso",39.

Posteriormente continuada sob aspectos também sociológicos, a criminologia positivista, de um modo geral, reconhece o crime como um fenômeno natural e social cujo estudo exige a adoção de metodologia empírica-experimental no intuito de descobrir as suas causas e orientar os caminhos para a ordenação do problema criminal ${ }^{40}$. Sob tais

\footnotetext{
${ }^{37}$ CARVALHO, Salo. Penas e medidas de segurança no direito penal brasileiro, cit., p. 75.

${ }^{38}$ ZAFFARONI, Eugenio Raúl; BATISTA, Nilo; ALAGIA, Alejandro; SLOKAR, Alejandro, ZAFFARONI, Eugenio Raúl; BATISTA, Nilo; ALAGIA, Alejandro; SLOKAR, Alejandro. Direito Penal Brasileiro I, cit., p. 126 .

${ }^{39}$ Cf. LOMBROSO, Cesare. O homem criminoso. 4 ed. Trad. Maria Carlota Carvalho Gomes. Rio de Janeiro: Editora Rio, 1983.

40 "Na base deste paradigma, a Criminologia (por isso mesmo positivista) é definida como uma Ciência causal-explicativa da criminalidade; ou seja, que tendo por objeto a criminalidade concebida como um fenômeno natural, causalmente determinado, assume a tarefa de explicar as suas causas segundo o método científico ou experimental e o auxílio das estatísticas criminais oficiais e de prever os remédios para combatê-la. Ela indaga, fundamentalmente, o que o homem (criminoso) faz e por que o faz". ANDRADE, Vera Regina Pereira de. Sistema penal máximo x cidadania mínima: códigos da violência na era da globalização. Porto Alegre: Livraria do Advogado, 2003, p. 35.
} 
influxos, o estudo da criminologia continuou seu caminho sob o paradigma etiológico de busca das causas (naturais) do delito para uma correta intervenção corretiva.

A análise central dos estudiosos passa a ser a personalidade do agente criminalizado e as condições que determinaram a prática do delito. A partir da descoberta das causas do crime cumpre realizar um diagnóstico para a intervenção corretiva, ou seja, a pena converte-se em uma espécie de tratamento das causas que determinaram a prática do crime e produz seus efeitos sobre o indivíduo criminalizado. A análise da personalidade do agente e o desenvolvimento do conceito de periculosidade, tão presentes ainda na prática do sistema de justiça criminal brasileiro contemporâneo, conduzem a um modelo punitivo de cunho terapêutico que incorpora tanto um modelo moral como um médico-policial na teoria e prática da pena ${ }^{41}$.

Se até então os discursos sobre a pena recebiam os influxos dos campos do direito e da filosofia política, a partir do modelo positivista da pena como tratamento, incorporamse à temática da pena, com proeminência, os discursos médicos, psicológicos, pedagógicos e do serviço social ${ }^{42}$.

Entre os teóricos do direito penal, foi com a obra de Franz von Liszt que a prevenção especial positiva ganhou força. Em 1882, sob forte influência do positivismo, altamente prestigiado naquele momento histórico, Liszt publica o Programa de Marburgo $^{43}$, texto que se tornou clássico e no qual o autor classifica os delinquentes em corrigíveis, incorrigíveis e aqueles que não necessitam de correção. Para os que "não estão perdidos sem salvação possível (...) poderiam ser postos à salvo em muitos casos, mas só com uma educação severa e prolongada" ${ }^{, 44}$.

Em meados do século passado o discurso da prevenção especial positiva foi revigorado tanto pelos autores da chamada Nova Defesa Social ${ }^{45}$, como pelo advento do Estado de Bem-Estar Social nos países centrais, trazendo aquilo que David Garland chamou de previdenciarismo penal nos países anglo-saxões. Conforme aponta o professor

\footnotetext{
${ }^{41}$ ZAFFARONI, Eugenio Raúl; BATISTA, Nilo; ALAGIA, Alejandro; SLOKAR, Alejandro, ZAFFARONI, Eugenio Raúl; BATISTA, Nilo; ALAGIA, Alejandro; SLOKAR, Alejandro. Direito Penal Brasileiro I, cit., p. 125.

${ }^{42}$ CARVALHO, Salo. Penas e medidas de segurança no direito penal brasileiro, cit., p. 76.

${ }^{43}$ LISZT, Franz von. La idea del fin en el Derecho Penal. Trad. Carlos Pérez del Valle. Granada: Ed. Comares, 1995.

${ }^{44}$ ibidem, p. 88.

${ }^{45}$ Cf. ANCEL, Marc. A nova defesa social: um movimento de política criminal humanista. Trad. Osvaldo Melo. Rio de Janeiro: Forense, 1979.
} 
da Universidade de Nova York, o princípio reitor do enquadramento penal-previdenciário era a reabilitação, que servia como "o substrato intelectual e o valor sistêmico que unia toda a estrutura e que fazia sentido para os operadores do sistema" ${ }^{26}$.

A prevenção especial positiva e o discurso muitas vezes considerado humanista que a sustenta estão ainda muito presentes na prática do sistema penal, especialmente na execução da pena no Brasil contemporâneo. Com efeito, a ideia de ressocialização ou terapêutica penal ainda é verdadeiramente influente no curso da execução da pena, porém mais como forma de limitação de direitos da pessoa condenada do que como um projeto humanista do declarado objetivo de reinserção social.

As críticas à teoria da prevenção especial positiva ganham corpo com a desconstrução do paradigma criminológico positivista e seu viés etiológico e patologizante do fenômeno criminal. A ideia do crime como uma manifestação natural do sujeito criminoso, defendida a partir do erro metodológico ${ }^{47}$ de pesquisa empírica realizada sobre sujeitos já selecionados por todos os filtros do sistema de criminalização secundária, em verdade serviu para mascarar um processo de ordenação de problemas sociais como a pobreza $^{48}$ e seu respectivo processo de controle por meio do sistema penal.

Se a ideia central de identificação do problema criminal no indivíduo criminoso é seguramente negada por estudos criminológicos de cunho crítico, a consequente prática de realização de diagnóstico para a medida corretiva representada pela pena cai por terra igualmente. As interpretações moralizadoras sobre a personalidade do sujeito criminalizado, bem como a elaboração de laudos de aferição de periculosidade, representam resquícios da concepção ressocializadora e de melhoramento do sujeito que, mesmo com a negação do paradigma etiológico, permanecem no cotidiano da execução penal brasileira como práticas autoritárias de limitação da liberdade dos sujeitos por meio de um discurso declaradamente benéfico para o indivíduo ${ }^{49}$.

\footnotetext{
${ }^{46}$ GARLAND, David. A cultura do controle: crime e ordem social na sociedade contemporânea. Trad. André Nascimento. Rio de Janeiro: Revan, 2008, p. 104.

${ }^{47}$ Cf. SHECAIRA, Sérgio Salomão. Criminologia. 2. ed. São Paulo: Editora Revista dos Tribunais, 2009, p. 136; BARATTA, Alessandro. Criminologia crítica e crítica do direito penal, cit., p. 40.

${ }^{48}$ ANDRADE, Vera Regina Pereira de. Sistema penal máximo x cidadania mínima, cit., p. 41.

${ }^{49}$ É o caso, por exemplo, do exame criminológico, sistematicamente utilizado como meio para negar direitos na execução penal para indivíduos "ainda não ressocializados". Cf. CARVALHO, Salo. O (novo) papel dos "criminólogos" na execução penal: as alterações estabelecidas pela Lei 10.792/03. In.: CARVALHO, Salo (org.). Crítica à execução penal. 2. ed. Rio de Janeiro: Lumen Juris, 2007, p. 159 e ss.. De maneira semelhante, o discurso ressocializador impões diversas formas de tratamento diferenciado na execução penal,
} 
Para além das críticas de cunho criminológico, as ideias correcionalistas também sofreram um combate no plano filosófico diante da secularização característica dos Estados ocidentais modernos. O pluralismo político e a secularização no contexto democrático impedem que o Estado possa intervir no âmbito da autonomia da consciência individual, de modo que a interioridade e o modo de ser da pessoa devem ser preservados frente a uma tentativa de torná-la aquilo que ela não é e não deseja ser, ou seja, o Estado não possui legitimidade para transformar pessoas segundo seus modelos.

Mesmo que posteriormente revigorada com um viés humanista de reinserção social, a qual ocorreria através de ações positivas estatais sem o objetivo de interferência direta na autonomia individual pelo melhoramento do sujeito, a teoria da prevenção especial positiva não ficou isenta de severas críticas, principalmente porque seu discurso não foi capaz de impedir, senão que continuou a legitimar práticas autoritárias na execução penal, tais como os laudos e diagnósticos ainda baseados na ideologia "re"

A teoria da prevenção especial positiva também ignora que os destinatários de suas finalidades e práticas constituem um grupo muito pequeno selecionado pelo processo de criminalização. Em países como o Brasil, há a predominância de um grupo social com características específicas que é selecionado pelo sistema punitivo ${ }^{51}$, que de maneira alguma se confunde com o conjunto de pessoas que cometeram delito naquele mesmo período de seleção penal, ou seja, não há justificativa racional para que práticas ressocializadoras ou de reinserção social sejam destinadas apenas a esse determinado grupo, uma vez que a prática de fatos puníveis é comum a todos os grupos sociais. Se a criminalidade e a criminalização não se confundem, parece claro que não se alcançará a prevenção do delito por meio de medidas impostas apenas a um grupo pequeno e determinado de pessoas, ainda que se considere tais medidas como efetivas.

a partir do prisma da "periculosidade". Cf. PAVARINI, Massimo; GIAMBERARDINO, André. Teoria da pena e execução penal: uma introdução crítica. Rio de Janeiro: Lumen Juris, 2011, p. 328 e ss.

${ }^{50}$ Nesta seara, David Garland destaca criticamente o poder conferido aos técnicos na execução da pena: “A natureza individualizante, indeterminada e altamente discricionária das práticas correcionalistas conferiam às autoridades do sistema uma extensa latitude no tratamento de condenados ou de jovens necessitados. Criminosos identificados como perigosos, reincidentes ou incorrigíveis podiam ficar detidos por longos períodos. Aqueles que possuíssem antecedentes respeitáveis ou fortes vínculos com o trabalho e a família eram tratados com mais leniência. As medidas penais podiam ser ajustadas para adaptarem-se ao nível de subserviência ou de risco apresentado pelo criminoso; e criminosos responsáveis por crimes bárbaros podiam ser condenados a penas que correspondessem à sua culpabilidade e que atendessem às expectativas públicas." GARLAND, David. A cultura do controle, cit., p. 105. No Brasil, cf. CARVALHO, Salo. O (novo) papel dos "criminologos" na execução penal, cit., passim.

${ }^{51}$ Cf. PAVARINI, Massimo; GIAMBERARDINO, André. Teoria da pena e execução penal, cit., p. 119 e ss. 
Todavia, a mais contundente crítica da teoria em tela é aquela que se refere à estrutural incapacidade da pena privativa de liberdade de alcançar os fins propostos pela prevenção especial positiva. Com efeito, os deletérios efeitos do encarceramento sobre a vida das pessoas são duradouros e conflitantes com a ideia de um bem para o sujeito. A prisão, como instituição total ${ }^{52}$, carrega consigo uma série de características que contribuem para a deterioração do sujeito preso e configura uma forma de infligir dor e sofrimento, que a torna incompatível com os declarados efeitos de melhora e reinserção social. A ideia de ressocializar um indivíduo retirando-o do convívio social constitui uma contradição insuperável, de modo que se torna "insustentável a pretensão de melhorar mediante um poder que impõe a assunção de papéis conflitivos e que os fixa através de uma instituição deteriorante". 53

Há, contudo, outra versão da prevenção especial que é chamada de negativa e consiste na defesa da mera neutralização do sujeito criminalizado para que sua inocuização impeça a prática de novos delitos. Trata-se de uma finalidade da pena que também tem raízes na criminologia positivista, tendo sido desenvolvida para aqueles indivíduos classificados como irrecuperáveis $^{54}$, cujo destino reservava apenas o seu isolamento no cárcere. Novamente a ideia de contenção de um perigo representado pela pessoa toma conta do discurso sobre a pena em uma ideia mais direta de defesa social. No caso desta versão da prevenção especial, no entanto, não se pretende qualquer objetivo de motivação do comportamento humano, senão sua direta inocuização, o que faz com que o direito penal nem trate seu destinatário como pessoa ${ }^{55}$.

A prevenção especial negativa não costuma ser modernamente sustentada senão em combinação com as demais teorias legitimadoras da pena, especialmente com a versão positiva da prevenção especial, muito embora seja, no plano concreto, o discurso que maior influência exerça sobre os operadores da política criminal brasileira contemporânea de gestão da miséria pela criminalização da pobreza e tenha algum êxito preventivo especial, pois "a morte e os demais impedimentos físicos são eficazes para suprimir

\footnotetext{
52 "Uma instituição total pode ser definida como um local de residência e trabalho onde um grande número de indivíduos com situação semelhante, separados da sociedade mais ampla por considerável período de tempo, levam uma vida fechada e formalmente administrada." GOFFMAN, Erving. Manicômios, prisões e conventos. 8. ed. Trad. Dante Moreira Leite. São Paulo: Perspectiva, 2008, p. 11.

${ }^{53}$ ZAFFARONI, Eugenio Raúl; BATISTA, Nilo; ALAGIA, Alejandro; SLOKAR, Alejandro. Direito Penal Brasileiro I, cit., p. 126.

${ }^{54}$ Cf. LISZT, Franz von. La idea del fin en el Derecho Penal, cit., p. 83 e ss.

${ }^{55}$ ZAFFARONI, Eugenio Raúl; BATISTA, Nilo; ALAGIA, Alejandro; SLOKAR, Alejandro, op. cit., p. 128.
} 
condutas posteriores do mesmo sujeito",56, ainda que somente no ambiente externo à prisão. A neutralização, conforme as palavras de Eugenio Raúl Zaffaroni, Nilo Batista, Alejandro Alagia e Alejandro Slokar "é somente uma pena atroz imposta por seleção arbitrária",57, especialmente utilizada diante do constante fracasso da prevenção especial positiva.

\section{2 - Alternativas diante da crise}

Se por um lado as críticas recebidas pelas teorias da pena no plano teórico foram insuficientemente respondidas no âmbito dos seus discursos legitimadores, por outro lado, no plano concreto as referidas teorias foram incapazes de atingir os fins a que se destinavam. A escassa solidez fundamentadora do conjunto teórico acima descrito acabou por gerar uma permanente crise nos discursos sobre a pena ${ }^{58}$, diante da qual era inevitável que houvesse alguma modificação no estado da arte da teoria da pena, ainda que o tema central de estudo dos penalistas durante o último século tenha sido a chamada teoria do delito.

Diante desse quadro, nas últimas décadas as inovações sobre o tema caminharam principalmente ${ }^{59}$ em três sentidos: a) uma tentativa de conservação das principais teorias da pena em um discurso unificador; b) a negação dos efeitos positivos de todas as teorias justificadoras da pena em uma teoria agnóstica; c) a tentativa de inovação sobre os discursos da pena na moderna teoria da prevenção geral positiva.

Se por um lado as reações à crise das teorias da pena confirmam de alguma forma a existência dessa conjuntura, por outro reavivam a discussão sobre a legitimidade da pena

\footnotetext{
56 ibidem, p. 127.

${ }^{57}$ ZAFFARONI, Eugenio Raúl; BATISTA, Nilo; ALAGIA, Alejandro; SLOKAR, Alejandro. Direito Penal Brasileiro I, cit., p. 127.

58 ibidem, p. 114.

${ }^{59}$ Os três caminhos apontados, evidentemente, não esgotam o conjunto de teorizações sobre a pena, senão que representam aquelas de maior importância ou repercussão no âmbito do direito penal brasileiro. Para uma crítica materialista e dialética da pena, cf. SANTOS, Juarez Cirino dos. Teoria da pena, cit., p. 19 e ss.; para outros modelos contemporâneos de justificação da pena, cf. CARVALHO, Salo. Penas e medidas de segurança no direito penal brasileiro, cit., p. 91 e ss.
} 
e tentam retirar do segundo plano o debate sobre a questão que, na verdade, é central para as ciências criminais. Cumpre ressaltar que os três caminhos teóricos citados igualmente conferiram à questão da pena um papel central no âmbito do direito penal, de modo a modificar os elementos da teoria do delito com base na teoria dos fins da pena.

\subsection{1 - Teoria unificadora da pena}

Contemporaneamente, o pensamento penal majoritário adota aquilo que se convencionou chamar de teoria unificadora da pena. Trata-se de um discurso que reúne em si as teorias legitimadoras da pena e tenta, pelas supostas qualidades de cada uma, superar os defeitos que lhes são inerentes.

Em verdade, há mais de uma vertente unificadora a depender da adoção ou exclusão de determinada vertente legitimadora da pena. A mais conhecida foi elaborada por Claus Roxin e representa a versão exposta neste espaço diante de sua maior influência no penalismo contemporâneo. Com efeito, a teoria unificadora de Roxin reúne as teorias exclusivamente preventivas em uma relação pretensamente dialética entre prevenção geral e especial, sem prejuízo de o próprio autor ter apresentado outras vertentes que englobam também as teorias retributivistas ${ }^{60}$.

A teoria unificadora de Claus Roxin não admite qualquer fim para a pena senão aqueles unicamente preventivos, pois para o autor as normas penais só estão justificadas quando tendem à proteção da liberdade individual e a uma ordem social a seu serviço, o que não é possível através de um discurso retributivo, vale dizer, somente a prevenção seria capaz de representar um bem para a sociedade e para a liberdade individual em um Estado de Democrático de Direito.

Para o professor de Munique, a pena deve ter conjuntamente fins preventivos gerais e especiais, uma vez que os fatos delitivos podem ser evitados tanto por meio da influência sobre o particular como sobre a coletividade, sendo ambos os fins igualmente legítimos para tanto. Segundo a concepção unificadora, a persecução simultânea dos fins preventivos

\footnotetext{
${ }^{60}$ ROXIN, Claus. Derecho penal, cit., p. 93.
} 
especiais e gerais, em regra, não gera problemas do ponto de vista prático, especialmente quando "a pena declarada na sentença concreta é adequada para alcançar ambos os fins tão eficazmente quanto seja possível"61.

Contudo, Claus Roxin admite que há casos em que os fins da pena entram em conflito, especialmente quando os fins preventivos exigem quantidades distintas de pena ${ }^{62}$. Nesses casos, ressalta o autor que a prevenção especial deve prevalecer, desde que se garanta um "mínimo preventivo-geral",63, pois assim a prevenção geral não anularia a especial e ao mesmo tempo garantiria a confiança no ordenamento jurídico.

A servir de medida limitadora da pena em toda a teoria preventiva unificadora, Claus Roxin adiciona o princípio da culpabilidade ao conteúdo do seu discurso sobre a pena. Desta maneira, a duração da reprimenda jamais poderia ultrapassar a medida da culpabilidade, ainda que haja algum interesse de tratamento, segurança ou intimidação a justificar uma penal mais longa ${ }^{64}$.

A despeito de majoritária, as teorias unificadoras da pena sofrem duras críticas, especialmente porque representam verdadeira revitalização e relegitimação do conjunto de teorias cuja escassa solidez fundamentadora impunha a permanente crise da pena. A unificação em torno das supostas qualidades trazidas isoladamente por cada uma das teorias da pena não foi suficiente para tornar o discurso legítimo frente à manifestação concreta do direito penal.

A problemática da unificação do discurso pelas qualidades também é uma questão controversa em virtude daquilo que cada autor adepto da concepção unificadora considera como uma qualidade a unificar. Por exemplo, se Claus Roxin, por um lado, elimina a ideia de uma prevenção especial positiva impositiva, ou seja, uma espécie de ressocialização involuntária e obrigatória, por outro lado trabalha com os conceitos de defeitos de socialização, ressocialização e necessidade da pena como tratamento, ainda que somente voluntário, daquela pessoa ainda não adaptada ao convívio social harmônico. Ao ignorar o processo seletivo de criminalização secundária, o autor relegitima a prevenção especial positiva conforme critérios que, de fato, não podem ser considerados como positivos a partir de uma análise crítica do processo de criminalização.

\footnotetext{
${ }^{61}$ ibidem, p. 95.

${ }^{62}$ ROXIN, Claus. Derecho penal, cit., p. 96.

63 ibidem, p. 97.

64 ibidem, p. 99-100.
} 
Cumpre observar que é comum que se mencione a adoção de uma teoria unificadora da pena pelo art. 59 do Código Penal Brasileiro, que determina a aplicação da pena conforme seja necessária e suficiente para reprovação e prevenção do crime. Ocorre que a enunciação das funções da pena no plano normativo não tem o condão de fazer com que elas tenham a representação declarada no plano da realidade concreta, de modo que pouca ou nenhuma diferença faz o que enuncia a lei nesse sentido, salvo para referendar determinadas práticas punitivas. De fato, não é o que está disposto na lei penal que representa as funções reais da pena, senão a sua própria representação na realidade, incapaz de ser captada em uma formalização jurídica artificial ${ }^{65}$.

Ao final, as teorias unificadoras da pena constituem o maior exercício legitimador da pena, pois ao mesmo tempo revigoram todos os discursos já desconstruídos criticamente e os defendem apenas sob os supostos aspectos positivos que trazem consigo, como se fosse possível eliminar elementos negativos estruturais de determinados conjuntos teóricos apenas a partir da unificação de suas pretensas qualidades em um plano teórico ideal.

Com efeito, Eugênio Raúl Zaffaroni, Nilo Batista, Alejandro Alagia e Alejandro Slokar alertam que a visão conjunta das teorias da pena dão lugar a construções diversas e completamente incompatíveis e tal conjunto "na prática, traduz-se em uma pluralidade de discursos legitimantes que permitem 'racionalizar' qualquer decisão, através tão-somente da escolha do discurso mais apropriado entre os que estão apresentados." ${ }^{~} 66 \mathrm{Na}$ obra de Claus Roxin esta crítica assume uma particular pertinência, pois em mais de uma passagem o autor alemão deixa claro que "não se requer uma prevenção desde todos os pontos de vista ao mesmo tempo." ${ }^{, 67}$ Isso faz com que se possibilite uma prática tópica de decisão para apenas depois encontrar o fundamento da pena adequado ao caso ${ }^{68}$.

Diante das críticas expostas, pode-se concluir que, para além de um discurso unificador, a teoria em tela unifica a dor representada pela pena e reacende o discurso

\footnotetext{
${ }^{65}$ Cf. ZAFFARONI, Eugenio Raúl; BATISTA, Nilo; ALAGIA, Alejandro; SLOKAR, Alejandro. Direito Penal Brasileiro I, cit., p. 98. Mais adiante, apontam os autores que a positivação das funções da pena “conferem à prisão uma função que as ciências sociais comprovadamente declaram ser impossível." ibidem, p. 113.

66 ibidem, p. 114.

${ }^{67}$ ROXIN, Claus. Derecho penal, cit., p. 95. Nas páginas seguintes em mais de uma passagem a escolha se confirma. Por todas, citamos: "Mas os inevitáveis extravios tampouco podem conduzir a um "fiasco da teoria da pena”, porque a função preventiva geral da pena pode fundamentar por si só a pena se for necessário e não se vê menoscabada pelos fracassos preventivos-especiais que se possam produzir aqui ou alí.” ibidem, p. 96, tradução livre.

${ }^{68}$ ZAFFARONI, Eugenio Raúl; BATISTA, Nilo; ALAGIA, Alejandro; SLOKAR, Alejandro, op. cit., p. 114.
} 
legitimador da pena diante da crise permanente em que se encontra. Para além das críticas às teorias da pena isoladamente consideradas, a teoria unificadora tem a marca da renovação dos velhos discursos, em uma espécie de sobrevida, que permita a perpetração das práticas punitivas da sociedade moderna.

\subsection{2 - A teoria agnóstica da pena}

Em caminho diametralmente oposto ao das teorias unificadoras da pena, surge no contexto crítico latino-americano a teoria negativa ou agnóstica da pena, formulada inicialmente por Eugênio Raúl Zaffaroni ${ }^{69}$. Referida teoria não tenta resgatar as teorias positivas clássicas e surge justamente do fracasso das teorias legitimadoras da pena, por serem consideradas falsas ou, ao menos, não generalizáveis, ou seja, seus efeitos positivos, na hipótese de existirem, limitam-se a pouquíssimos casos e não são capazes de validar a pena como prática punitiva dotada de racionalidade positiva para a promoção da liberdade e da dignidade humana.

Para o autor argentino, no âmbito estatal convivem o modelo de Estado de Direito em conjunto com um Estado de Polícia, ambos em verdadeira disputa. Ainda que formalmente tenha se consolidado do contexto ocidental uma concepção de Estado de Direito, coexiste dentro deste um Estado de Polícia, o qual opera em constante tentativa de aniquilação do primeiro.

Uma das manifestações mais marcantes do Estado de Polícia que sobrevive dentro do Estado de Direito é justamente o poder punitivo, em virtude do seu modo irracional e ilegítimo de atuação. Trata-se de um poder exercido de forma autoritária e que conduz a um modelo de sociedade verticalizada e disciplinadora por meio de um processo de criminalização que seleciona de maneira arbitrária a parcela da população mais vulnerável

\footnotetext{
${ }^{69}$ A deslegitimação do sistema penal foi exposta de maneira pioneira em ZAFFARONI, Eugenio Raúl. Em busca das penas perdidas: a perda de legitimidade do sistema penal. Trad. Vânia Romano Pedrosa e Almir Lopes da Conceição. 5.ed. Rio de Janeiro: Revan, 2001; posteriormente sistematizada em ZAFFARONI, Eugenio Raúl; ALAGIA, Alejandro; SLOKAR, Alejandro. Derecho penal: parte general. 2. ed. Buenos Aires: Ediar, 2002. Na literatura brasileira, cf. a adoção também por Nilo Batista em ZAFFARONI, Eugenio Raúl; BATISTA, Nilo; ALAGIA, Alejandro; SLOKAR, Alejandro. Direito Penal Brasileiro I, cit., p. 97 e ss
} 
e acaba por reproduzir antagonismo sociais como resultado desse processo de controle social $^{70}$.

As teorias da pena cumprem um papel fundamental no plano do fomento ou da limitação do poder punitivo, de modo que para a compreensão da teoria negativa da pena é preciso avaliar os discursos sobre a pena a partir das funções por ela exercidas. Eugenio Raúl Zaffaroni diferencia as funções da pena em manifestas (ou declaradas) e reais (ou latentes), pois as penas carregam consigo não só os papéis que as teorias da pena afirmam que elas exercem, senão que é inseparável de sua compreensão igualmente as funções que realizam na sua manifestação concreta para além daquilo que é declarado no plano discursivo ou mesmo legal.

As teorias clássicas da pena acima descritas são consideradas teorias positivas da pena, no sentido de que a defendem como um bem a ser proporcionado pelo Estado para a sociedade ou para determinadas pessoas criminalizadas. Desta forma, se a pena constitui um bem, o Estado tem o dever e o direito de utilizá-la quantas vezes julgar necessário e conveniente ${ }^{71}$.

Todavia, a questão central reside na ignorância pelos defensores das teorias positivas da pena das funções reais exercidas pela punição no plano concreto, o que culmina na legitimação destas por meio das funções declaradas, ou seja, as teorias positivas da pena legitimam o poder real exercido pelo poder punitivo $^{72}$, que é o único realizado na realidade social. As funções declaradas, que em verdade são falsas, constituem um meio de legitimação das funções reais e fomento ao exercício do poder punitivo autoritário e irracional, considerado, todavia, como um bem.

A despeito de reconhecerem o desconhecimento de todas as funções reais exercidas concretamente pelo poder punitivo, os defensores da teoria negativa e agnóstica de pena ressaltam o poder de vigilância e controle social e político de pessoas, ideias e movimentos, além do caráter essencialmente verticalizador das relações sociais, de modo a revelar a configuração essencialmente conservadora e autoritária do poder punitivo estatal $^{73}$. Por outro lado, a pena concretamente considerada como exercício do poder

\footnotetext{
${ }^{70}$ Cf. ZAFFARONI, Eugenio Raúl; BATISTA, Nilo; ALAGIA, Alejandro; SLOKAR, Alejandro. Direito Penal Brasileiro I, cit., p. 96.

71 ibidem, p. 97.

72 ibidem, p. 96.

73 "Pretender isolar as funções reais da pena do poder punitivo é uma formalização jurídica artificial: o maior poder do sistema penal não reside na pena, mas sim no poder de vigiar, observar, controlar movimentos e
} 
punitivo também é exposta em suas estruturas e seus deletérios efeitos de estigmatização, deterioração da pessoa humana e reprodução das desigualdades sociais.

Se as teorias positivas da pena necessariamente legitimam e impulsionam o poder punitivo do Estado com as consequentes funções reais que exerce, Eugenio Raúl Zaffaroni propõe a criação de uma teoria que negue qualquer função positiva à pena (negativa) e admita desconhecer todas as funções que cumpre (agnóstica), muito embora reconheça que aquelas atribuídas pelo direito penal, por meio das teorias positivas, são falsas ou não generalizáveis. Com efeito, defende ser esta concepção a única forma de construir um conjunto teórico capaz de conter o poder punitivo, uma vez que essa tarefa é impossível para qualquer teoria positiva, como restou historicamente demonstrado.

Para além de não reconhecer qualquer função positiva à pena, o penalista argentino a concebe como um exercício de poder que não tem explicação jurídica ou racional, mas somente do ponto de vista político. E como exercício de poder, não podem ficar de fora de seu conceito as reais manifestações que cumpre no plano concreto, como a tortura, as execuções policiais e os agravamentos ilícitos das penas juridicamente postas, pois a qualificação do chamado direito penal subterrâneo ${ }^{74}$ como pena é o que permite apontar para a ilicitude de tais atos. As funções reais da pena, portanto, não podem escapar ao seu conceito e horizonte de projeção do direito penal, caso contrário sua manifestação na realidade continuaria a ser ignorada.

Para a teoria negativa, "a pena é uma coerção, que impõe uma privação de direitos ou uma dor, mas não repara nem restitui, nem tampouco detém as lesões em curso ou neutraliza perigos iminentes." ${ }^{, 75}$ Por não abarcar qualquer função positiva à pena e ampliar seu horizonte de projeção para as reais funções por ela exercidas, a teoria negativa pretende limitar o poder punitivo do Estado.

ideias, obter dados da vida privada e pública, processá-los, arquivá-los, impor penas e privar de liberdade sem controle jurídico, controlar e suprimir dissidências, neutralizar as coalizões entre desfavorecidos etc. Se existe alguma dúvida acerca do enorme poder verticalizador do sistema penal, basta olhar para a experiência histórica: o sindicalismo, o pluralismo democrático, o reconhecimento da dignidade das minorias, a própria república, conseguiram estabelecer-se sempre em luta contra esse poder. Qualquer inovação social que se fizer em prol do desenvolvimento humano deverá enfrentar o sistema penal: todo conhecimento e todo pensamento abriu caminho confrontando-se com o poder punitivo. A história ensina que os avanços da dignidade humana sempre ocorreram em luta contra o poder punitivo”. ZAFFARONI, Eugenio Raúl; BATISTA, Nilo; ALAGIA, Alejandro; SLOKAR, Alejandro. Direito Penal Brasileiro I, cit., p. 98-99.

${ }^{74}$ ibidem, p. 69-70.

75 ibidem, p. 99. 
$\mathrm{O}$ arcabouço jurídico-penal construído a partir da teoria negativa da pena passa a se constituir em uma forma de contenção do poder punitivo do Estado sem legitimá-lo, tal qual restou forjado no âmbito do direito internacional humanitário. Seus teóricos realizam, então, um paralelo entre a pena e a guerra, uma vez que ambas constituem atos políticos de violência ilegítimos ${ }^{76}$ diante dos quais o direito deve exercer um papel unicamente limitador da violência que os caracteriza.

A incidência do direito diante de determinados atos, especialmente aqueles que representem violência e constante violação da dignidade humana, não precisa ser necessariamente fator de sua legitimação, embora historicamente muitas vezes tenha sido. Se ao longo da história o direito tentou encontrar fundamentos legitimadores da guerra e estabelecer os parâmetros de uma "guerra justa", em determinado momento os juristas reconheceram a ilegitimidade deste ato político e, diante da sua inevitabilidade, passaram a direcionar o direito internacional humanitário para a contenção dos seus deletérios efeitos concretos.

A teoria negativa da pena pretende realizar semelhante prática com o saber jurídico-penal diante da pena, vale dizer, negar a legitimidade deste exercício de poder político e, diante de sua permanência na vida social, construir formas de sua contenção e constante limitação. Não é porque a pena existe e determinada lei lhe atribui uma função positiva que o jurista precisa encontrar fundamentos legitimadores (positivos), se o cotejo com a realidade concreta demonstra sua irracionalidade e ilegitimidade com os compromissos democráticos de promoção da liberdade e dignidade da pessoa humana. $\mathrm{O}$ saber penal só se torna legítimo, portanto, ao reconhecer a ilegitimidade da pena e, diante disso, se constitui como um instrumento de sua constante limitação.

Surge, portanto, no contexto latino-americano, em cujo ambiente o poder punitivo se revela de maneira especialmente violenta, uma teoria crítica da pena notadamente forjada para sua própria contenção. A difusão ${ }^{77}$ e crítica $^{78}$ do recente discurso negativo da

\footnotetext{
${ }^{76}$ A analogia é declaradamente inspirada na construção semelhante de Tobias Barreto, que com raro acerto apontava em 1892 que "quem procura o fundamento jurídico da pena deve também procurar, se é que já não encontrou, o fundamento jurídico da guerra”. Cf. BARRETO, Tobias. Fundamentos do direito de punir. Revista dos Tribunais, n. 727, 1996, p. 650, originalmente publicado em Estudos de direito; Rio de Janeiro, Laemmert \& C. Editora, 1. ed., 1892, p. 161-179.

${ }^{77}$ Para além de difusão por Nilo Batista na obra em conjunto com Eugenio Raúl Zaffaroni, Alejandro Alagia e Alejandro Slokar, cf. na literatura jurídica brasileira a referência à teoria agnóstica da pena em CARVAlHO, Salo de. Teoria Agnóstica da Pena: entre os supérfluos fins e a limitação do poder punitivo. In.: CARVALHO, Salo de. (Org.). Crítica à execução penal. Rio de Janeiro: Lumen Juris, 2002; CARVALHO, Salo de. Antimanual de criminologia. 2. ed. Rio de Janeiro: Lumen Juris, 2008, p. 125 e ss.;
} 
pena no Brasil revela, com efeito, a sua importância e consistência teórica em uma temática cuja característica principal não era propriamente a originalidade.

\subsection{3 - Teoria da prevenção geral positiva}

As teorias unificadora e negativa da pena foram forjadas a partir do fracasso das teorias legitimadoras singularmente consideradas e constituem discursos inovadores, mas que se limitam ao âmbito de análise dos discursos clássicos sobre a pena: a teoria unificadora da pena resgata e une as teorias legitimadoras da pena em um discurso fundamentador único, enquanto a teoria negativa da pena rechaça todos esses discursos e constrói um novo aporte teórico crítico sobre a pena.

No entanto, outro caminho foi trilhado pelo professor alemão Günther Jakobs, que igualmente insatisfeito com as respostas dadas pelas teorias tradicionais da pena, resgata as ideais inicialmente esboçadas pelo seu professor Hans Welzel e funda, sob as bases de uma nova concepção de sociedade trazida pelo funcionalismo sociológico, a teoria da prevenção geral positiva da pena ${ }^{79}$.

Se outros autores também inauguraram versões da teoria da prevenção geral positiva da pena, é com Jakobs que esse discurso legitimador da sanção penal recebe feições inovadoras ${ }^{80}$ no domínio das ciências criminais. A característica central e

CARVAlHO, Salo de. Penas e medidas de segurança no direito penal brasileiro, cit, p. 141 e ss; BOZZA, Teorias da pena, cit., p. 103 e ss; BUSATO, Paulo César. Direito penal: parte geral. São Paulo: Atlas, 2013, p. 794 e ss. Para uma abordagem da deslegitimação da pena a partir do abolicionismo e do minimalismo, cf. QUEIROZ, Paulo. Direito penal: parte geral. 5. ed. Rio de Janeiro: Lumen Juris, 2009, p. 104 e ss.

${ }^{78}$ Para uma crítica da teoria agnóstica ou negativa da pena, cf. SANTOS, Juarez Cirino dos. Teoria da pena, cit., p. 17 e ss.

${ }^{79}$ Cf. Cf. JAKOBS, Günther. Derecho penal: parte general. Fundamentos y teoría de la imputación. Trad. Joaquín Cuello Contreras y José Luis Serrano Gonzalez de Murillo. 2. ed. Madrid: Marcial Pons, 2003; JAKOBS, Günther. Culpabilidad y prevención, In: Estudios de Derecho Penal. Trad. de Carlos J. Suárez González. Madrid: Ediciones de la Universidad Autónoma de Madrid y Editorial Civitas, 1997; JAKOBS, Günther. Sociedad, norma y persona en una teoría de un derecho penal funcional. Trad. de Manuel Cancio Meliá y Bernardo Feijoo Sánchez. Madrid: Civitas, 2000; JAKOBS, Günther. La pena estatal: significado y finalidad. Trad. Manuel Cancio Meliá y Bernardo Feijoo Sánchez. Madrid: Civitas, 2006.

${ }^{80}$ Trata-se, contudo, de uma inovação relativa, conforme se demonstrará na exposição das bases e influências buscadas pelo autor nos capítulos seguintes. 
diferenciadora da prevenção geral positiva de Jakobs reside na busca de um referencial externo ao direito para fundar a legitimação da pena e do direito penal de maneira geral. Foi sob a égide do modelo de sociedade compreendido pelo funcionalismo sociológico, especialmente em seu viés sistêmico, que o penalista de Bonn elaborou uma nova fundamentação para o sistema punitivo estatal.

Para Jakobs, a norma penal constitui uma necessidade funcional sistêmica de estabilização das expectativas sociais por intermédio da aplicação da pena ante a frustração que decorre da violação da norma. Considera-se que as interações sociais geram expectativas que devem ser asseguradas como condição de preservação do sistema social. O delito configura uma expressão simbólica de falta de fidelidade ao direito e ameaça a integridade e a estabilidade do sistema social. Por seu turno, a pena protege as condições para as interações interpessoais e tem função preventiva na medida em que assegura a validade da norma, tida como o próprio bem jurídico-penal, e restabelece a confiança para a estabilidade e integração do sistema social ${ }^{81}$.

A teoria da prevenção geral positiva da pena de viés sistêmico despertou grande interesse no campo das ciências criminais, especialmente nos países ocidentais que recebem a influência do direito penal alemão, constituindo-se, com efeito, na versão mais destacada e controversa da teoria da pena nas últimas décadas. De fato, o pensamento de Günther Jakobs não passa despercebido entre os estudiosos do direito penal, especialmente pela inovação que significou. Todavia o conjunto teórico construído não revolve, senão agrava a crise das terias legitimadoras da pena.

A despeito das críticas que recebeu, a teoria da prevenção geral positiva da pena do funcionalismo sistêmico não foi objeto de uma desconstrução verdadeiramente radical entre seus críticos. Diante disso, torna-se ainda necessária uma análise crítica que vá de encontro às raízes do pensamento de Jakobs, aponte para o significado do referencial sociológico e jurídico-filosófico adotado pelo autor e desvele as consequências políticocriminais deste referencial teórico. Para tanto, a descrição dos alicerces fundamentais e da evolução do pensamento do autor constituem uma tarefa necessária para a posterior desconstrução e crítica da prevenção geral positiva de base funcionalista sistêmica.

${ }^{81}$ Cf. JAKOBS, Günther. Derecho penal, cit, p. 9 e ss. 


\section{CAPÍTULO 2 - AS RAÍZES SOCIOLÓGICAS DO FUNCIONALISMO SISTÊMICO}

SUMÁRIO: 2. As raízes sociológicas do funcionalismo sistêmico - 2.1. Émile Durkheim e a fundação do funcionalismo - 2.1.1. O positivismo e as origens da sociologia - 2.1.2. Émile Durkheim e o funcionalismo na sociologia - 2.1.3. Émile Durkheim e o direito penal - 2.2. Talcott Parsons e o desenvolvimento do funcionalismo - 2.3. Niklas Luhmann e a teoria dos sistemas - 2.3.1. A influência do pensamento de Niklas Luhmann - 2.3.2. A sociologia de Niklas Luhmann - 2.3.3. O direito em Niklas Luhmann.

A construção da teoria da prevenção geral positiva por Jakobs teve na sociologia a marca de sua originalidade. Com efeito, foi a partir da particular maneira de entender a sociedade e com a utilização dos conceitos elaborados pelo funcionalismo sociológico, que Jakobs imprimiu um novo debate na penologia contemporânea. Assim, para uma melhor compreensão do significado da prevenção geral positiva, cumpre elaborar um percurso do significado do funcionalismo na sociologia e esclarecer seus principais conceitos, sem os quais a teoria da pena do autor alemão não teria o reconhecido relevo no âmbito do direito penal moderno.

\section{1 - Émile Durkheim e a fundação do funcionalismo}

\subsection{1 - O positivismo e as origens da sociologia}

As transformações na estrutura da sociedade que culminaram na formação do que se entende por modernidade modificaram também a maneira de refletir sobre a realidade 
que se apresentava. Com efeito, as decorrências econômicas da Revolução Industrial, o legado político da Revolução Francesa e o alcance cultural do Renascimento e do Iluminismo moldaram um novo modelo de sociedade, caracterizado por intensas e constantes transformações ${ }^{82}$.

É inerente ao pensamento humano a observação e reflexão sobre o que rodeia os indivíduos, isto é, sobre o seu entorno social. Até o advento da modernidade, todavia, os fenômenos sociais eram objeto de estudo da filosofia ${ }^{83}$, mas a ordem social moderna indicou a insuficiência daquela para explicar o modelo de sociedade que se anunciava. $\mathrm{O}$ surgimento da sociologia coincide, portanto, com a necessidade de compreensão da vida em sociedade de forma global, de modo que a análise dos fenômenos sociais englobe os respectivos processos e estruturas.

Neste caminhar, os insuficientes objetos de estudo da filosofia política e da filosofia da história foram ampliados de modo a abranger a totalidade dos fenômenos sociais. Além do objeto, o método de análise também se altera para abarcar o processo experimental e a observação da realidade empírica ${ }^{84}$. Nasce, assim, um original campo de pensamento social destinado a compreender e explicar o novo modelo de sociedade caracterizado por constantes transformações: a sociologia.

A nova ciência avocou a difícil tarefa de explicar as causas e características das transformações sociais a fim de apontar o caminho a ser enfrentado diante dos problemas que afligiam os homens de seu tempo. Tal aspiração era alimentada pelo desenvolvimento do método científico nas ciências da natureza, que poderia conferir a pretendida confiança para a compreensão não apenas dos fenômenos da natureza, mas também daqueles de caráter social.

O principal embrião teórico da sociologia que se formava era o pensamento do filósofo Augusto Comte. Seu percurso intelectual se desenvolve em meio ao movimento iluminista, tendo como enfoque a crítica às ideias religiosas por meio da valorização da razão e da ciência. Comte buscará na influência direta que recebeu de Saint-Simon e no

\footnotetext{
${ }^{82}$ Cf. SELL, Carlos Eduardo. Sociologia Clássica: Marx, Durkheim e Weber. Petrópolis: Vozes, 2009, p. 16; BITTAR, Eduardo C. B. O direito na pós-modernidade (e reflexões frankfurtianas). 2. ed. Rio de Janeiro: Forense Universitária, 2009, p. 42.

${ }^{83}$ Sobre os antecedentes intelectuais da sociologia, cf. BOTTOMORE, T. B. Introdução à sociologia. Trad. de Waltensir Dutra e Patrick Burglin. 9. ed. Rio de Janeiro: LTC, 2008, p. 16 e ss; COLLINS, Randall. Quatro tradições sociológicas. Trad. de Raquel Weiss. Petrópolis: Vozes, 2009, p. 13 e ss.

${ }^{84}$ SELL, Carlos Eduardo, op. cit., p. 21.
} 
precedente pensamento de Condorcet, a defesa da aplicação do método das ciências naturais na explicação social. Ao mesmo tempo em que se impõe como um pensador iluminista, pretendeu superar o pensamento metafísico característico daquele ideário de valorização da razão separada da realidade com a adoção do método experimental e a compreensão científica do mundo a partir da observação dos fatos.

A partir da Revolução Industrial, segue-se um tempo de otimismo decorrente do progresso da ciência e das técnicas, o qual certamente influenciou o pensamento de Augusto Comte ${ }^{85}$. Distante das crenças religiosas e opositor da especulação metafísica, o filósofo inaugurou o positivismo como sistema de pensamento através do qual o espírito humano chegaria a uma compreensão científica do mundo a partir da observação dos fatos $^{86}$.

O filósofo positivista desenvolveu, então, a "lei dos três estados", em que defendeu a existência de uma lei fundamental segundo a qual o pensamento humano, em qualquer área do conhecimento, passa sucessivamente por três diferentes estados históricos de evolução: o estado teológico, o estado metafísico e o estado positivo ou científico. $\mathrm{O}$ estados de pensamento teológico e metafísico seriam etapas transitórias para o conhecimento verdadeiramente científico, o positivo ${ }^{87}$, única opção válida de explicação da realidade.

Aliado ao sentimento antimetafísico, o método experimental é outro elemento fundamental do pensamento positivista, uma vez que as outras formas de conhecimento humano não seriam passíveis de negação ou confirmação. A partir da compreensão científica do mundo, seria possível descobrir as leis fundamentais que regem os fenômenos sociais, as causas das ações sociais, e, a partir daí, pensar de forma correta os problemas enfrentados pela humanidade em cada período histórico. Assim como nas ciências naturais, a explicação da sociedade far-se-ia a partir das relações causais entre os fenômenos e culminaria na exposição de um sistema integral de leis que explicassem todos os fatos sociais. O conhecimento científico, finalmente, chegaria às ciências humanas e desempenharia o papel de apontar o caminho para o progresso da sociedade.

\footnotetext{
${ }^{85}$ Augusto Comte fora aluno e professor da Escola Politécnica de Paris, criada nesse mesmo contexto de desenvolvimento científico após a Revolução Industrial, o que influenciou diretamente sua formação.

${ }^{86}$ Cf. MASCARO, Alysson Leandro. Lições de Sociologia do Direito. São Paulo: Quartier Latin, 2007, p. 69-70.

${ }^{87}$ Cf. COMTE, Augusto. Discurso sobre o espírito positivo: ordem e progresso. Trad. Renato Barbosa Rodrigues Pereira. Porto Alegre: Globo/EDUSP, 1976.
} 
Ao transplantar o método das ciências naturais para a pesquisa social, o positivismo introduziu o axioma da neutralidade valorativa e da objetividade no estudo da sociedade. Uma análise verdadeiramente científica seria aquela que deriva da observação objetiva dos fenômenos, sem qualquer consideração subjetiva, ética ou política que contaminaria a cientificidade da pesquisa.

Nesse sentido, o positivismo é caracterizado pela existência de três premissas fundamentais em sua figuração "ideal-típica", conforme aponta de maneira percuciente Michel Löwy: a) harmonia natural da sociedade, que é regida por leis invariáveis; b) utilização da metodologia das ciências naturais; c) neutralidade e objetividade do pesquisador $^{88}$. Destaca, ainda, o autor a importante distinção entre o positivismo e o que chama de dimensão positivista, que é a qualificação que caracteriza uma investigação quando encontra-se presente algum dos três axiomas que formam a estrutura descrita do positivismo.

A ciência natural da sociedade, que inicialmente era chamada por Augusto Comte de física social ${ }^{89}$, e somente depois passou a ser denominada pelo neologismo sociologia, nascia com as raízes deitadas em todas as premissas do positivismo, seu embrião ideológico. Em uma sociedade inebriada pela ideia de progresso, desponta um novo campo de estudos que irá, em seu início, preocupar-se essencialmente com a manutenção da ordem estabelecida.

Outro importante precursor da sociologia foi o inglês Herbert Spencer e seu darwinismo social. Inspirado pelo evolucionismo de Charles Darwin, Spencer concebeu uma analogia biológica da sociedade, a qual teria, em muitos aspectos, uma natureza orgânica. Verifica-se, assim, mais uma vez a influência das ciências naturais nas origens da sociologia, mais precisamente, aqui, a biologia. $\mathrm{O}$ recurso às analogias biológicas e sua

\footnotetext{
88 "1. A sociedade é regida por leis naturais, isto é, leis invariáveis, independentes da vontade e da ação humana; na vida social reina uma harmonia natural. 2. A sociedade pode, portanto, ser epistemologicamente assimilada pela natureza (o que classificaremos como "naturalismo positivista") e ser estudada pelos mesmo métodos, démarches e processos empregados pelas ciências da natureza. 3. As ciências da sociedade, assim como as da natureza, devem limitar-se à observação e à explicação causal dos fenômenos, de forma objetiva, neutra, livre de julgamentos de valor ou ideologias, descartando previamente todas as prenoções e preconceitos." LÖWY, Michel. As aventuras de Karl Marx contra o Barão de Münchhausen: marxismo e positivismo na sociologia do conhecimento. Trad. de Juarez Guimarães e Suzane Felicie Léwy. 9. ed. São Paulo: Cortez, 2009, p. 19-20.

89 "Sem admirar nem maldizer os fatos políticos, vendo-os essencialmente, como em qualquer outra ciência, como simples temas de observações, a física social considera, portanto, cada fenômeno sob o duplo ponto de vista elementar de sua harmonia com os fenômenos coexistentes e de seu encadeamento com o estado anterior e posterior do desenvolvimento humano". COMTE, Augusto. Cours de philosophie positive, t. IV, p. 214. Apud, LÖWY, Michel, op. cit., p. 28.
} 
inseparável dimensão positivista encontra-se ainda presente em determinadas correntes sociológicas modernas, como, por exemplo, em algumas construções do funcionalismo sistêmico.

Para Spencer, a sociedade é um organismo sui generis ${ }^{90}$, que apresenta um conjunto de elementos comuns aos organismos biológicos. A sociedade se transforma segundo leis evolutivas inerentes aos organismos naturais, de um conjunto simples e homogêneo até atingir níveis de complexidade características da sociedade moderna. A evolução da sociedade, tal qual nos organismos, aumenta sua complexidade estrutural, bem como a diferenciação de funções entre suas partes constitutivas.

Segundo este evolucionismo organicista de Spencer, os membros da sociedade e suas instituições desempenham funções distintas e coordenadas para o funcionamento do todo social $^{91}$. A análise da sociedade passa, portanto, necessariamente pelo estudo das funções que cada um de seus elementos exerce para o conjunto da sociedade e sua evolução.

As influências do positivismo comtiano e do evolucionismo organicista de Spencer na formação da sociologia foram marcantes, mormente na linha de pensamento desenvolvida pelo francês Émile Durkheim, conhecida como funcionalismo.

\subsection{2 - Émile Durkheim e o funcionalismo na sociologia}

Se por um lado foi por meio do trabalho de Augusto Comte que as premissas fundamentais para a formação da sociologia foram criadas, por outro lado foi a partir da obra de Émile Durkheim que ela atingiu sua afirmação científica e academicamente como disciplina autônoma. Durante seu percurso acadêmico, Durkheim pretendeu dotar a sociologia de um método consistente próprio e consolidá-la como uma ciência

\footnotetext{
${ }^{90}$ GINER, Salvador. Historia del pensamiento social. 12. ed. Ariel: Barcelona, 2008, p. 636.

${ }^{91}$ Conforme o autor, “(...) as relações permanentes, que existem entre as partes de uma sociedade, são análogas às relações permanentes que existem entre as partes de um corpo vivo". SPENCER, Herbert. Principes de Sociologie. Traduzido do inglês por E. Cazelles e J. Gerschel. $6^{\circ}$ ed. Paris: Alcan, 1910, t. 2, p.3. Apud, FERNANDES, Florestan. O método de interpretação funcionalista na sociologia. In.: Fundamentos empíricos da explicação sociológica. Companhia Editora Nacional: São Paulo, 1959, p. 202.
} 
independente. Após sua nomeação como professor da Universidade de Bordeaux em 1887, Durkheim leciona o primeiro curso de sociologia criado em uma universidade ${ }^{92}$.

No aspecto metodológico, a obra de Durkheim é uma continuação dos intentos comtianos de dotar a sociologia de um método sólido de pesquisa da sociedade e seus fenômenos ${ }^{93}$. O positivismo, com efeito, foi a principal influência intelectual de Durkheim $^{94}$ em sua busca pela consolidação da sociologia como ciência capaz de descrever as leis que regem o funcionamento da sociedade. As premissas essenciais que formam o positivismo foram, de fato, assumidas pelo sociólogo francês na formação da nova ciência.

O princípio metodológico fundamental da sociologia em formação consistia na adoção do método das ciências da natureza. Afirmava Durkheim, já no prefácio à edição inaugural de sua primeira grande obra, Da Divisão do Trabalho Social, que seu estudo representava "um esforço para tratar os fatos da vida moral a partir do método das ciências positivas" $"$. A cientificidade buscada naquele momento só seria possível com o emprego dos métodos já aplicados com sucesso nos campos de conhecimento impulsionados e impulsionadores do desenvolvimento tecnológico daquele período histórico.

O caráter científico exigido para a disciplina requeria, por outro lado, uma postura neutra, imparcial e objetiva do pesquisador. Para tanto, o objeto de estudo da sociologia, o fato social ${ }^{96}$, era "coisificado", artifício necessário para ser analisado da mesma maneira

\footnotetext{
92 Também foi em sua cátedra na Universidade de Paris-Sorbonne que o termo sociologia, como denominação da disciplina, aparece pela primeira vez em 1913. Durkheim também foi o fundador da importante revista L'Anné Sociologique, principal instrumento de divulgação dos trabalhos da "Escola Sociológica Francesa" que se formava sob sua liderança. Sobre a importância de Durkheim para a formação da sociologia, cf. GINER, Salvador. Teoría Sociológica Clásica. 3. ed. Barcelona: Ariel, 2011, p. 225 e ss.; SELL, Carlos Eduardo. Sociologia Clássica, cit., p. 77 e ss.

${ }^{93}$ SELL, Carlos Eduardo, op. cit., p. 77. A continuidade metodológica é admitida expressamente pelo próprio Durkheim quando aponta que seus escritos "derivam diretamente de Comte; são momentos diferentes de uma mesma evolução". DURKHEIM, Émile. La sociologie, 1915, em Textes, 1, Élements d'une théorie sociale, Éditions de Minuit, 1975, p. 115. Apud, LÖWY, Michel. As aventuras de Karl Marx contra o Barão de Münchhausen, cit., p. 30.

${ }^{94}$ Carlos Eduardo Sell assinala ainda o evolucionismo, o conservadorismo e o idealismo kantiano como influências importantes no pensamento de Durkheim ao lado do positivismo. Cf. SELL, Carlos Eduardo, op. cit., p. 80 .

${ }^{95}$ DURKHEIM, Émile. Da divisão do trabalho social. Trad. Eduardo Brandão. 2. ed. São Paulo: Martins Fontes, 1999, p. V. No mesmo sentido, continua: "Os fatos morais são fenômenos como os outros; eles consistem em regras de ação que se reconhecem por certas características distintivas; logo, deve ser possível observá-los, descrevê-los, classificá-los e procurar as leis que os explicam. (...) ninguém contesta a possibilidade das ciências físicas e naturais. Reclamamos o mesmo direito para nossa ciência."

96 "É fato social toda maneira de fazer, fixada ou não, suscetível de exercer sobre o indivíduo uma coerção exterior; ou ainda, toda maneira de fazer que é geral na extensão de uma sociedade dada e, ao mesmo tempo,
} 
que a física ou a química analisam seus respectivos objetos. Assim, para Durkheim "a primeira regra e a mais fundamental é a de considerar os fatos sociais como coisas."97 Transformar o fato social em coisa foi o meio pelo qual se buscou a objetividade do pesquisador, pressuposto para que a disciplina apresentasse um caráter universal ${ }^{98}$. Quaisquer considerações de caráter valorativo retirariam o caráter científico do estudo sociológico, que deveria ficar limitado à observação e consequente explicação causal dos fenômenos. Assim, o tratamento do fato social como coisa tem como primeiro corolário a busca pela posição de neutralidade e objetividade do observador, sob o alerta do sociólogo francês: "é preciso descartar sistematicamente todas as prenoções."99

A sociologia de Durkheim perseguirá, por outro lado, a descoberta de leis estáveis que demonstrem as relações existentes entre os fatos sociais e, assim, o funcionamento da sociedade. A tarefa do sociólogo fica limitada a uma explicação causal dos fenômenos, de modo a encontrar as leis naturais que regem a vida em sociedade. Assim como se entendiam os fenômenos físicos naquele período histórico, também os de caráter social seriam submetidos a leis naturais descobertas através de uma cadeia causal de fatos. $\mathrm{O}$ determinismo da regularidade causal dos fatos sociais apontava para a constatação de que a sociedade era regida igualmente por leis naturais ${ }^{100}$.

A utilização do método das ciências naturais, a defesa da neutralidade do sociólogo e o pressuposto de que a sociedade é regida por leis naturais invariáveis demonstram a adoção da epistemologia positivista por Émile Durkheim e a influência direta do pensamento de Augusto Comte na sociologia que se formava como campo de conhecimento autônomo.

\footnotetext{
possui uma existência própria, independente de suas manifestações individuais.” DURKHEIM, Émile. As regras do método sociológico. Trad. Paulo Neves. 3. ed. São Paulo: Martins Fontes, 2007, p. 13.

97 ibidem, p. 15.

${ }^{98}$ MASCARO, Alysson Leandro. Lições de Sociologia do Direito, cit., p. 75.

${ }^{99}$ DURKHEIM, Émile, op. cit., p. 32. A necessidade de extirpar toda as considerações subjetivas da análise sociológica era ressaltada com veemência pelo autor: "Pode-se portanto supor que, expulso de ciência em ciência, esse preconceito acabará por desaparecer da própria sociologia, seu ultimo refúgio, para deixar o terreno livre ao cientista.". ibidem, p. 35.

100 "Pode mesmo dizer-se que, de todas as leis, a melhor estabelecida experimentalmente - porque se lhe não conhece uma única exceção depois de ter sido verificada uma infinidade de vezes, é que proclama que todos os fenômenos naturais evoluem segundo leis. Portanto, se as sociedades estão na natureza, devem obedecer, também elas, a esta lei geral que resulta da ciência e ao mesmo tempo a domina." DURKHEIM, Émile. A ciência social e a ação. Trad. Inês D. Ferreira. São Paulo: Difel, 1975, p. 79.
} 
Além do emprego do método positivista, a sociologia durkheimniana inaugurou um importante paradigma de análise sociológica, o holismo metodológico ${ }^{101}$. O ponto de partida para a explicação dos fenômenos sociais é a sociedade, o coletivo, que não só funciona de maneira independente dos indivíduos, como condiciona sua ações. As estruturas sociais criadas pelos homens assumem uma dinâmica particular de funcionamento que independe da ação humana, de maneira que o ponto de partida para a análise da vida social está na dinâmica da sociedade, e não nas ações dos sujeitos. A sociologia deveria, então, explicar como o funcionamento das estruturas sociais determina o comportamento dos indivíduos em sociedade.

Esta sociedade, que é considerada o ponto de partida para a explicação dos fenômenos sociais, será compreendida, a partir da aplicação do método científico aos estudos sociais, por meio de uma analogia ao organismo biológico. Com efeito, a sociologia organicista de Spencer influenciou a formação do pensamento de Durkheim, principalmente nos temas escolhidos para pesquisa, bem como na maneira como eram $\operatorname{tratados}^{102}$.

Ainda que a analogia adotada entre sociedade e organismo não fosse direta como em Spencer, o sociólogo francês a utilizava como ponto de partida para análise dos fenômenos sociais ${ }^{103}$. Ao lado da explicação causal dos fenômenos, era preciso investigar também a função social que estes realizavam, não com base na utilidade projetada individualmente, o que geraria uma visão finalista da sociologia, mas sim determinar as consequências positivas dos fenômenos sociais para o conjunto da sociedade ${ }^{104}$.

A explicação da sociedade a partir da função social dos fatos remete, pois, à influência organicista na formação da escola sociológica francesa, uma vez que o próprio termo "função" tem origem nas ciências biológicas. A análise das causas e das funções

\footnotetext{
${ }^{101}$ Cf. SELL, Carlos Eduardo. Sociologia Clássica, cit., p. 81.

${ }^{102}$ Cf. FERNANDES, Florestan. O método de interpretação funcionalista na sociologia, cit., p. 205.

103 “A palavra função é empregada de duas maneiras bastante diferentes. Ora designa um sistema de movimentos vitais, fazendo-se abstração das suas consequências, ora exprime a relação de correspondência que existe entre esses movimentos e algumas necessidades do organismo. (...). É nessa segunda acepção que entendemos a palavra.” DURKHEIM, Émile. Da divisão do trabalho social., cit., p. 13.

104 "Preferimos servir-nos do termo função em vez de fim ou objetivo, precisamente porque os fenômenos sociais não existem geralmente com vista aos resultados úteis que produzem. O que é necessário determinar é se existe correspondência entre o fato considerado e as necessidades gerais do organismo social e em que consiste esta correspondência, sem nos preocuparmos em saber se foi ou não intencional." DURKHEIM, Émile. As regras do método sociológico, cit., p. 135.
} 
sociais constituiriam a maneira científica de explicação da realidade social para a corrente funcionalista que se formava ${ }^{105}$.

Há, ainda, um pressuposto de fundamental importância na sociologia funcionalista de Durkheim, que consiste na consideração da sociedade como um todo harmônico e consensual. A preocupação do sociólogo francês era descobrir a funcionalidade dos fenômenos para a manutenção da harmonia social e, por consequência, da ordem existente. Ao contrário das outras duas linhas clássicas de desenvolvimento da sociologia, representadas por Max Weber e Karl Marx, que buscavam identificar as formas de dominação social e os conflitos a ela inerentes, a sociologia de Durkheim buscava entender as causas pelas quais se dá a coesão social e as funções positivas dos fatos sociais para a manutenção dessa coesão ${ }^{106}$. Por isso mesmo, sua sociologia está classificada dentro da categoria das teorias do consenso, ou seja, aquele grupo teórico que considera a sociedade como um sistema harmônico e interpreta conflitos e crises sociais como manifestações de disfuncionalidade e patologia social ${ }^{107}$.

O pressuposto consensual e harmônico da sociedade, por outro lado, influenciou diretamente na eleição dos temas que seriam pesquisados pelo autor, não sendo, portanto, obra do acaso que em sua primeira grande pesquisa publicada, Da Divisão do Trabalho Social, a temática gire em torno da solidariedade como mecanismo de integração dos indivíduos nas diferentes formas de sociedade ${ }^{108}$. É também pelo mesmo motivo que o direito penal foi objeto de constante investigação ao longo da vida acadêmica de Durkheim, que, por sua vez, influenciou de maneira singular as ciências criminais.

\footnotetext{
${ }^{105}$ Nesse sentido, Florestan Fernandes: "A análise das causas e a análise das funções sociais constituiriam os meios de investigação capazes de conduzir, de acôrdo com as propriedades e as condições dos fenômenos considerados, a aplicação daquele ponto de vista à explicação científica da realidade social." FERNANDES, Florestan. O método de interpretação funcionalista na sociologia, cit., p. 210-211.

${ }^{106}$ Nesse sentido aponta Alysson Leandro Mascaro que "Por extensão, Durkheim sempre desenvolve sua reflexão tendo em vista a autoridade, a norma, a coerção, porque sua pesquisa orienta-se para um sentido de compreensão da ordem social.” MASCARO, Alysson Leandro. Lições de Sociologia do Direito, cit.,p. 77.

${ }^{107}$ Cf. SABADELL, Ana Lúcia. Manual de sociologia jurídica: introdução a uma leitura externa do direito. 4. ed. São Paulo: Editora Revista dos Tribunais, 2008, p. 81 e ss; SHECAIRA, Sérgio Salomão. Criminologia, cit., p. 138 e ss.

${ }^{108}$ Pelo mesmo motivo o suicídio também foi objeto de estudo do autor, uma vez que constitui o extremo oposto da solidariedade social: "o suicídio só acontece quando os laços sociais são tão fracos que o indivíduo acha a vida sem sentido, e por isso decide tirar a própria vida. (...) Durkheim não estava interessado no suicídio propriamente dito, mas em mostrar como operam as condições normais de integração social." COLLINS, Randall. Quatro tradições sociológicas, cit., p. 160.
} 


\subsection{3 - Émile Durkheim e o direito penal}

A busca por elementos que possibilitassem a convivência coletiva harmônica e a coesão social levou Durkheim a pesquisar as origens da solidariedade social. Sua principal preocupação era compreender as formas de solidariedade que acompanhavam a evolução da sociedade, com destaque particular para as origens da solidariedade nas sociedades modernas que pareciam constituir um mundo sem categorias compartilhadas em virtude da especialização das funções sociais e do individualismo. Era, pois, na solidariedade que o sociólogo francês pesquisava o fundamento do bem-estar social e das ações necessárias para o funcionamento do organismo social.

Nessa investigação sobre solidariedade e coesão social, o castigo e a punição constituíram o objeto central de sua análise sociológica. Para além de seu estudo como meio de prevenção e controle do crime, a sanção penal era examinada a partir de sua importância funcional para a vida em sociedade e constituiu um elemento chave para a elaboração de uma teoria social própria.

Para Durkheim, a sociedade demanda um padrão moral que reflita as condições vigentes da organização social. A categoria da punição alcançou, então, uma relevância substancial em sua sociologia, pois corresponderia a uma representação dessa ordem moral da sociedade e um fator determinante para aferir como esta se sustenta.

Como consequência da centralidade que a punição recebe na construção da teoria social do autor francês, sua vasta obra perpassará temas muito caros às ciências criminais, de modo que seu pensamento ganha especial relevo na quadra histórica atual em que um dos mais destacados discursos no âmbito do direito penal é identificado como funcionalismo penal.

Em sua principal obra, Da Divisão do Trabalho Social, Durkheim buscará analisar a natureza variável da moralidade e da solidariedade social, além de investigar de que forma tais elementos constituem um fator essencial para a coesão social. Para o autor, a divisão do trabalho social é o fator fundamental de solidariedade social nas sociedades modernas, e empreenderá, a partir dessa "verdade evidente"109, um estudo para determinar

${ }^{109}$ DURKHEIM, Émile. Da divisão do trabalho social, cit., p. 30. 
"em que medida a solidariedade que ela produz contribui para a integração geral da sociedade" $" 110$.

Para explorar sua hipótese, Durkheim utiliza-se de um elemento que simbolizaria externamente a solidariedade social e seus efeitos sensíveis no mundo: o direito. Em sua concepção, o direito é a forma de organização mais estável e assente da vida social, em que podem ser encontradas todas as formas essenciais da solidariedade social ${ }^{111}$. Por outro lado, apesar do caráter variável do direito a depender da evolução social, entende que, com a análise do campo jurídico atingirá a objetividade necessária para sua pesquisa, como sói acontecer nas demais ciências da natureza.

O direito como manifestação das diversas formas de solidariedade social é, portanto, claramente encarado como uma construção social consensual e garantidora da coesão dessa mesma sociedade. O fenômeno jurídico será, por sua vez, analisado em suas manifestações sociais pela sociologia, campo de estudo responsável pela pesquisa da solidariedade na sociedade.

A partir dos preceitos do direito, definidos por Durkheim como regras de conduta sancionadas, o sociólogo francês extrairá a classificação das diferentes espécies de solidariedade social. Conforme os tipos de sanções, o direito fora classificado em repressivo ou restitutivo, o primeiro compreenderia o direito penal, enquanto o último abarcaria os demais ramos do direitos, como o direito civil, o direito processual e o direito constitucional.

Nesta seara, "o vínculo de solidariedade social a que corresponde o direito repressivo é aquele cuja ruptura constitui o crime" $" 112$. Por sua vez, os crimes são aqueles atos universalmente reprovados pelos membros de cada sociedade que são reprimidos por castigos definidos ${ }^{113}$. Assim como sua postura com relação ao direito, o crime também é por ele visto de forma consensual, carregando consigo uma reprovação universal da sociedade, ainda que variável, em razão das transformações sociais.

\footnotetext{
${ }^{110}$ DURKHEIM, Émile. Da divisão do trabalho social, cit., p. 30.

111 "De fato, a vida social, onde quer que exista de maneira duradoura, tende inevitavelmente a tomar uma forma definida e a se organizar, e o direito nada mais é que essa mesma organização no que ele tem de mais estável e de mais preciso. A vida geral da sociedade não pode se estender num ponto sem que a vida jurídica nele se estenda ao mesmo tempo e na mesma proporção. Portanto, podemos estar certos de encontrar refletidas no direito todas as variedades essenciais da solidariedade social.” ibidem, p. 31-32.

112 ibidem, p. 41.

113 Todavia, o próprio autor excepciona seu conceito nos casos de ofensas contra o Estado. Criticamente, cf. GARLAND, David. Castigo y sociedad moderna, cit., p. 46-47.
} 
Para além de um ato que possui uma universal reprovação social, a definição de crime para Durkheim passa pela análise de um conceito caro à sua sociologia: a consciência coletiva ou comum. A consciência coletiva é "o conjunto de crenças e dos sentimentos comuns à média dos membros de uma mesma sociedade (que) constitui um sistema determinado que tem vida própria." 114 Já o crime é todo ato que "ofende os estados fortes e definidos da consciência coletiva"115.

Por constituir o crime uma violação a sentimentos e emoções profundamente arraigados e a valores quase sagrados na sociedade, o direito penal recebe uma autoridade extraordinária e provoca uma forte reação que é justamente a pena. O delito para Durkheim é um ofensa contra a ordem moral sagrada da sociedade, pois golpeia os sentimentos mais profundos de cada um de seus membros. O crime constitui, portanto, uma verdadeira violação à moralidade social e uma afronta pessoal contra qualquer indivíduo "são"116.

Já a pena, ao contrário das tradicionais caracterizações declaradamente racionais, seja de retribuição ou de prevenção do delito, ganha em Durkheim um caráter psicológico de vingança, definida como uma reação passional ${ }^{117}$.

Durkheim realizou um estudo histórico da pena em diversos tipos de sociedade, desde as mais primitivas até as modernas e concluiu que sua essência não se modificou, a despeito das justificativas que se pretendeu dar ao castigo nos diversos períodos históricos. A pena nasce como uma reação ao crime em forma de desejo intenso de vingança, uma fúria indignada que resulta em um inegável ato de violência ${ }^{118}$.

Conforme defende o sociólogo francês, "essa característica é tanto mais aparente quanto menos cultas são as sociedades" "119, mas não deixa de estar presente nos tipos sociais mais avançados, modificando-se, apenas, a qualidade e a quantidade do castigo, que continua a constituir, ao menos em parte, um ato de vingança ${ }^{120}$. Nas sociedades modernas tornou-se necessário avaliar com maior atenção o funcionamento dessa paixão

\footnotetext{
${ }^{114}$ DURKHEIM, Émile. Da divisão do trabalho social, cit., p. 50.

115 ibidem, p. 51.

${ }^{116}$ GARLAND, David. Castigo y sociedad moderna, cit., p. 48.

${ }^{117}$ DURKHEIM, Émile, op. cit., p. 56.

${ }^{118}$ GARLAND, David, op. cit., p. 47.

${ }^{119}$ Nesse sentido, assevera o autor que "os povos primitivos punem por punir, fazem o culpado sofrer unicamente para fazê-lo sofrer e sem esperar, para si, nenhuma vantagem do sofrimento que lhe impõem. Prova-o o fato de não procurarem punir de maneira justa ou útil, mas apenas punir.” DURKHEIM, Émile, op. cit., p. 57.

${ }^{120}$ Cf. SHECAIRA, Sérgio Salomão. Criminologia, cit., p. 222.
} 
vingativa, que oficialmente ganha um caráter racional e utilitário, mas não perde sua essência. A justificação moderna de que a pena teria se transformado em um ato de defesa da sociedade, "um instrumento metódico de proteção", cuja finalidade seria a prevenção das "más vontades malignas" pelo temor da pena, não corresponderia ao seu verdadeiro cerne $^{121}$.

Além de uma reação passional, a pena se revela como um inegável ato de imposição de sofrimento ao ser humano que, todavia, é considerado como justo ante o abalo proporcionado à consciência coletiva pela conduta criminosa. Constitui uma expiação do ato passado e, por essa relação, o sofrimento infligido deve ser proporcional ao mal causado pelo delito. Segundo Durkheim, “o que vingamos, o que o criminoso expia, é o ultraje à moral."122

Com a transformação da sociedade e o advento da modernidade, o que modifica na pena não é propriamente sua essência, que continua a configurar um ato passional de vingança a impor um sofrimento para expiação do passado, mas sim a imposição de limites à sua aplicação, que aumenta conforme a evolução da sociedade, a qual não mais admite e passa a se opor "às violências absurdas, aos estragos sem razão de ser"123.

Por fim, outra característica da pena para Durkheim é a intermediação de um corpo constituído para sua aplicação, mais propriamente um tribunal estabelecido. Assim, define a pena da seguinte maneira: "a pena consiste, pois, essencialmente, numa reação passional, de intensidade graduada, que a sociedade exerce por intermédio de um corpo constituído contra aqueles de seus membros que violaram certas regras de conduta." 124

Expostas as características basilares da pena em Durkheim, resta discorrer sobre sua função, ponto que destaca o pensamento do sociólogo no âmbito das ciências criminais. Para Durkheim, a pena, embora proceda de uma reação passional, mecânica e

\footnotetext{
121 "A natureza de uma prática não muda necessariamente porque as intenções conscientes dos que a aplicam se modificam. Ela já podia, com efeito, desempenhar o mesmo papel outrora, mas sem que isso fosse percebido. Nesse caso, por que se transformaria pelo simples fato de que percebem melhor os efeitos que ela produz? Ela se adapta às novas condições de existência que lhe são assim criadas sem mudanças essenciais. É o que acontece com a pena." DURKHEIM, Émile. Da divisão do trabalho social, cit., p. 58.

${ }^{122}$ ibidem, p. 60.

123 ibidem, p. 62.

124 ibidem, p. 68. Nesse sentido, Rodrigo Ghiringheli de Azevedo aponta a caracterização da pena em Durkheim da seguinte maneira: "a pena é uma reação passional; um ato de defesa da sociedade; um ato de expiação, proporcional à agressão; um ato executado de forma organizada". AZEVEDO, Rodrigo Ghiringheli. Sociologia e Justiça Penal: teoria e prática da pesquisa sociocriminológica. Rio de Janeiro: Lumen Juris, 2010, p. 122.
} 
em grande parte de movimentos irrefletidos, possui, por outro lado, um papel útil e fundamental no desenvolvimento da sociedade. O caráter preventivo, seja intimidador, seja corretivo, não seria um papel desempenhado pela pena, salvo de maneira meramente secundária, cuja eficácia é duvidosa e medíocre. Para o autor, o autêntico sentido da pena seria a manutenção da coesão e harmonia social, a afirmação da consciência comum e a consequente conservação da solidariedade social ${ }^{125}$.

Ao reparar o mal que o crime causa à sociedade, atesta-se que os sentimentos são sempre coletivos e reafirmam-se os valores fundantes da consciência comum. Da punição provém a solidariedade, que cumpre a função de reforçar os laços de integração, coesão e harmonia na sociedade. Mantém-se, assim, o defendido consenso em torno dos valores predominantes na sociedade através da aplicação de uma pena diante de um ato que contrariou a consciência coletiva.

A pena tem caráter dual: é, a um só tempo, uma questão de emoção psicológica individual e de moralidade social coletiva. Ambos aspectos coexistem em uma espiral funcional que ajuda a criar e recriar a coesão social ${ }^{126}$. Este caráter da pena existe em todas as sociedades, desde as mais primitivas às modernas formações sociais, variando, apenas, a intensidade da influência do direito penal na formação da solidariedade, uma vez que nas sociedades modernas a divisão do trabalho social assume um papel predominante, sem, contudo, retirar a importância da punição nesse processo funcional de manutenção da coesão social.

É, com efeito, em Da Divisão do Trabalho Social que Durkheim estabelece as bases do nascente funcionalismo penal. O caráter funcional da pena para a coesão social é reforçado em escritos posteriores em que o sociólogo francês retoma a temática do direito penal. Na virada do século, um trabalho importante sobre o tema vem à lume no Volume IV (1899-1900) da revista L'Anné Sociologique, o destacado ensaio As Duas Leis da Evolução Penal ${ }^{127}$. Se na primeira grande obra o sociólogo abordou com profundidade o

\footnotetext{
125 "Sua verdadeira função é manter intacta a coesão social, mantendo toda a vitalidade da consciência comum. Negada de maneira tão categórica, esta perderia necessariamente parte de sua energia, se uma reação emocional da comunidade não viesse compensar essa perda, e daí resultaria um relaxamento da solidariedade social. Portanto, é necessário que ela se afirme com vigor no momento em que for contradita, e o único meio de se afirmar é exprimir a aversão unânime, que o crime continua a inspira, mediante um ato autêntico que só pode consistir numa dor infligida ao agente". DURKHEIM, Émile. Da divisão do trabalho social, cit., p. 81-82.

${ }^{126}$ GARLAND, David. Castigo y sociedad moderna, cit., p. 51.

${ }^{127}$ DURKHEIM, Émile. Dos Leyes de la Evolución Penal. Trad. Mónica Escayola Lara. Delito y Sociedad. Revista de Ciências Sociales. N 13, 1999.
} 
funcionamento e o sentido social do direito penal, neste ensaio expandirá sua pesquisa para as formas reais de manifestação da pena por meio de uma análise histórica.

O ensaio expõe uma interessante dualidade da teoria penal de Durkheim ${ }^{128}$ : ao mesmo tempo em que constata a historicidade da pena através de sua evolução nas diversas quadras históricas, defende que sua função no processo social não se altera, sendo, portanto, imutável no tempo. O autor trabalha com a distinção entre as formas e as funções da pena, a primeira mutável com a transformações sociais, a segunda constante em seu papel de manutenção da coesão social.

A primeira lei da evolução penal está relacionada à intensidade da sanção penal, às suas variações quantitativas, que tendem a diminuir com o desenvolvimento e o avanço da sociedade $^{129}$. Segundo a perspectiva de Durkheim, as sociedades mais primitivas adotaram formas de punição mais cruéis em razão da maior intensidade dos laços que instituem a consciência coletiva. Por outro lado, nas sociedades mais avançadas os referidos laços ocupam uma influência menor no seio da sociedade, de modo que a intensidade da punição se torna menos severa. A intensidade da aplicação da pena, dessa forma, possui direta relação com a força da consciência coletiva no âmbito das relações sociais. Ao lado dessa primeira lei, o sociólogo destacou, em complemento, a influência dos regimes de governo na intensidade da pena, sendo característico de regimes absolutistas as formas de punição destacadamente draconianas.

A segunda lei da evolução penal, por sua vez, aponta para a adoção nas sociedades modernas da privação de liberdade como modelo padrão de sanção penal ${ }^{130}$. Trata-se, aqui, de uma lei relacionada à qualidade da punição que, mais benevolente frente às penas capitais e corporais, passa a predominar nas sociedades modernas como consequência direta das características da consciência coletiva nesses tipos sociais.

Contudo, conforme exposto, as transformações sociais são capazes de modificar apenas as formas de aplicação concreta da pena qualitativa e quantitativamente, sem alterar

\footnotetext{
${ }^{128}$ Cf. GARLAND, David. Castigo y sociedad moderna, cit., p. 53 e ss.

129 “A intensidade do castigo é maior na medida em que a sociedade pertence a um tipo menos desenvolvido e ao grau no qual o poder central tem um caráter mais absoluto". DURKHEIM, Émile. Dos Leyes de la Evolución Penal, cit., p. 635, tradução livre.

130 “O castigo que implica a privação da liberdade e somente disso por períodos de tempo que variam com a gravidade do crime, tende crescentemente a tornar-se o tipo normal de sanção.” ibidem, p. 642, tradução livre.
} 
a sua função, que permanece a mesma nos diversos modelos de sociedade: um meio de integração social sob os valores dominantes.

A centralidade da questão criminal em grande parte da obra de Émile Durkheim lançou sua influência para além do direito penal propriamente dito e assumiu uma importância extraordinária no âmbito da criminologia, campo de conhecimento em que se estabelece um capítulo necessário e destacado de seu desenvolvimento histórico e científico $^{131}$.

O conhecimento criminológico hegemônico no período histórico que antecedeu à investigação de Durkheim era dominado pelo paradigma etiológico da criminologia positivista. A Escola Positiva, cujos principais representantes eram Cesare Lombroso, Raffaele Garófalo e Enrico Ferri, buscava a explicação da criminalidade na anomalia dos autores de condutas criminalizadas e empenhava sua pesquisa para o combate das causas do fenômeno criminal através do tratamento adequado. Os expoentes do positivismo criminológico tratavam a questão criminal como um dado ontológico, que deveria ser estudado em suas causas como forma de garantia e defesa social.

Os estudos de Émile Durkheim contribuíram para uma verdadeira virada em direção sociológica da criminologia, inaugurando uma alternativa à concepção determinista de orientação biopsicológica e caracterológica que imperava até então. A despeito da forte influência filosófica do positivismo em seu pensamento, Durkheim foi um dos principais responsáveis pelo rompimento da análise feita pela chamada criminologia positivista ao negar o estudo do fenômeno criminal pelas suas causas e empreende-lo a partir do exame das suas consequências exteriores ${ }^{132}$.

\footnotetext{
${ }^{131} \mathrm{O}$ funcionalismo durkheimniano é destacado em capítulo apartado nas principais obras de criminologia. Cf. ANITUA, Gabriel Ignacio. Historias de los pensamientos criminológicos. Buenos Aires: Editores del Puerto, 2010, p. 268 e ss.; BARATTA, Alessandro. Criminologia crítica e crítica do direito penal, cit., p. 59 e ss; DIAS, Jorge Figueiredo; ANDRADE, Manuel da Costa. Criminologia: o homem delinquente e a sociedade criminógena. Coimbra: Coimbra Editora, 1997, p. 311 e ss; LARRAURI, Elena; CID MOLINÉ, José. Teorías Criminológicas: explicación y prevención de la delincuencia. Madrid: Bosch, 2001, p. 125 e ss; MAÍlLO, Alfonso Serrano. Introdução à Criminologia. Trad. de Luiz Regis Prado. São Paulo: Editora Revista dos Tribunais, 2007, p. 212 e ss; GARCIA-PABLOS DE MOLINA, Antonio. Tratado de Criminología. 3. ed. Valencia: Tirant lo Blanch, 2003, p. 787 e ss; MUÑOZ CONDE, Francisco; HASSEMER, Winfried. Introdução à Criminologia. Trad. de Cíntia Toledo Miranda Chaves. Rio de Janeiro: Lumen Juris, 2008, p. 71 e ss; PAVARINI, Massimo. Control y dominación: teorias criminológicas burguesas y proyecto hegemónico. Trad. Ignacio Muñagorri 5. ed. Madrid: Siglo XXI, 1996, p. 108 e ss; SHECAIRA, Sérgio Salomão, Criminologia, cit., p. 213 e ss; TAYLOR, Ian; WALTON, Paul; YOUNG, Jock. La nueva criminología: contribución a una teoría social de la conducta desviada. 3. ed. Trad. Adolfo Crosa. Buenos Aires: Amorrortu, 2007, p. 89 e ss.

${ }^{132}$ Cf. SHECAIRA, Sérgio Salomão, Criminologia, cit., p. 214.
} 
Ao contrário da consideração patológica e anômala da criminalidade defendida até então (paradigma etiológico da criminologia), o sociólogo francês postulará a normalidade do desvio em toda estrutura social, e que, dentro dos limites funcionais, é considerado um fator positivo, indispensável e saudável para o equilíbrio da vida social. O caráter funcional do crime para a integração social é explicitamente destacado pelo autor quando afirma que "o crime aproxima as consciências honestas e as concentra". ${ }^{133}$

Todavia, quando determinados limites são extrapolados, o fenômeno criminal passa a ser negativo para a existência e progresso da sociedade. É o que Durkheim denomina situação de anomia, um estado de desorganização social, de crise e desmoronamento das normas e dos valores vigentes, como um novo sistema de valores ainda não se afirmou.

A influência do pensamento de Durkheim sobre os diversos campos das ciências criminais é profundamente significativa ${ }^{134}$. No âmbito da sociologia, os autores que seguiram o desenvolvimento do paradigma funcionalista abordaram de uma maneira mais ou menos central o fenômeno criminal. A relação da escola funcionalista da sociologia com o direito penal, por sua vez, jamais esteve tão presente quanto no atual período histórico, em que a corrente de pensamento mais influente é conhecida justamente como funcionalismo penal.

\section{2 - Talcott Parsons e o desenvolvimento do funcionalismo}

Talcott Parsons foi um importante nome do funcionalismo sociológico ao longo do século XX. Desenvolveu um conjunto teórico de grande escala e complexidade, no qual

\footnotetext{
${ }^{133}$ DURKHEIM, Émile. Da divisão do trabalho social, cit., p. 75.

${ }^{134}$ Nesse sentido, Alessandro Baratta apontou as principais características da criminologia funcionalista inaugurada por Durkheim e posteriormente desenvolvida por Robert Merton: "1) As causas do desvio não devem ser pesquisadas nem em fatores bioantropológicos e naturais (clima, raça), nem em uma situação patológica da estrutura social. 2) O desvio é um fenômeno normal de toda estrutura social. 3) Somente quando são ultrapassados determinados limites, o fenômeno do desvio é negativo para a existência e o desenvolvimento da estrutura social, seguindo-se um estado de desorganização, no qual todo o sistema de regras de conduta perde valor, enquanto um novo sistema ainda não se afirmou (esta é a situação de "anomia"). Ao contrário, dentro de seus limites funcionais, o comportamento desviante é um fator necessário e útil para o equilíbrio e o desenvolvimento sócio-cultural." BARATTA, Alessandro. Criminologia crítica e crítica do direito penal, cit., p. 59-60.
} 
descreveu inúmeras categorias e imprimiu em sua obra uma ampla quantidade de esquemas e quadros que se subdividem na explicação do funcionamento da sociedade em larga abstração. Sua tarefa era ambiciosa e alimentada pelo otimismo epistemológico que almejava construir uma teoria sociológica capaz de captar toda a realidade mediante a elaboração de categorias analíticas gerais e abstratas ${ }^{135}$.

A sociologia de Parsons inaugura uma análise a partir de sistemas e subsistemas de ação, mas mantém o problema da ordem como questão central de seus estudos. Para o sociólogo estadunidense, a sociedade é uma das espécies de sistema social, que, por sua vez, é um subsistema do sistema geral humano de ação. Os outros subsistemas são o organismo comportamental, o sistema da personalidade do indivíduo e o sistema cultural.

O sistema social é aquele em que se dão as interações interindividuais, enquanto os demais perfazem o papel de ambiência condicionante, como o organismo comportamental que conta com os requisitos básicos da vida orgânica, o sistema cultural com a função de legitimação da ordem normativa, além da personalidade que se relaciona com a aprendizagem e o processo de socialização que motiva a participação social de acordo com os padrões socialmente valorados. Os sistemas têm a característica e uma tendência de manutenção da ordem e da interdependência entre as partes, mantendo fronteiras com seus ambientes.

A unidade básica do sistema social é a ação social, que é analisada dentro de um marco referencial de posições (ou status) e papéis que o ator social mantém no sistema. As análises sociais dependem, portanto, dos papéis desempenhados pelos atores, ou seja, pelas expectativas e pautas de conduta esperadas pelos atores sociais em função do seu status ou posição no sistema social ${ }^{136}$.

A característica central do sistema social descrito por Parsons é a sua estabilidade que se mantém no tempo em virtude do funcionamento dos elementos estruturais do sistema: os atores sociais, os papéis, as normas e os valores. A partir das relações e ajustes entre os componentes do sistema social e o seu entorno se configura a estabilização do sistema.

\footnotetext{
${ }^{135}$ SORIANO, Ramón. Sociología del derecho. Barcelona: Ariel, 1997, p. 142.

${ }^{136}$ Cf. PARSONS, Talcott. El sistema social. 2. ed. Trad. José Jiménez Blanco e José Cazorla Pérez. Madrid: Revista de Occidente, 1976.
} 
Para caracterizar esta relação entre os elementos estruturais do sistema e o seu entorno, Parsons elaborou o paradigma que ficou conhecido como "AGIL", conjunto de quatro imperativos funcionais necessários em todos os sistemas: (A - adaptation) adaptação, segundo o qual todo sistema deve se adaptar ao seu entorno e adaptar o entorno a suas necessidades; ( $\mathrm{G}$ - goal attainment) atingimento de metas, que se traduz na necessidade de todo sistema definir e alcançar suas metas primordiais; (I - integration) integração, pelo qual todo sistema deve regular a inter-relação entre suas partes constituintes e controlar a relação com os demais imperativos funcionais; ( $\mathrm{L}$ - latency) manutenção de padrões ou latência, compreendida como a tarefa de manutenção da motivação dos indivíduos e das pautas culturais que criam e mantém a motivação ${ }^{137}$.

De maneira primordial cada imperativo funcional corresponde a um dos quatro subsistemas: a função integradora cumpre ao sistema social, a adaptação ao organismo comportamental, o atingimento de metas aos sistema da personalidade e a manutenção de padrões ao sistema cultural. Os sistemas se diferenciam de acordo com a relação com o seu entorno.

A sociedade é um tipo de sistema social que atinge o nível mais elevado de autossuficiência como sistema em relação ao seu entorno. Há quatro subsistemas ou estruturas na sociedade que cumprem os imperativos funcionais citados: a economia com função de adaptação, a política como a responsável pelo atingimento de metas, o sistema fiduciário, constituído por processos ou unidade que reproduzem a cultura social (como escola e família), com o papel de latência, além da comunidade social, onde se situa o direito, com o papel de integração de seus componentes.

A preocupação central do funcionalismo de Parsons se centrou nas estruturas básicas da organização do sistema social, como os valores dominantes, a normas que regulam os comportamentos, a coletividade ou formas de agrupamentos e os papéis exercidos por pessoas e instituições na sociedade.

Este complexo e abstrato arcabouço teórico exerceu grande influência e fascínio na sociologia de seu tempo, porém a sociologia parsoniana não se dedicou ao tema do direito com maior atenção e destaque, a despeito da amplitude de sua obra. Ao direito foi reservado um papel desempenhado conjuntamente com outros elementos que contribuem para a integração social, constituindo-se em um subsistema do sistema normativo.

${ }^{137}$ Cf. RITZER, George. Teoría Sociológica Moderna. 5. ed. Tradução de Maria Teresa Casado Rodríguez. Madrid: McGraw-Hill, 2010, p. 118 e ss. 
Como parte do sistema normativo, o direito revela-se como uma estrutura normativa das sociedades mais avançadas em sua complexidade, bem como um código normativo que controla esta complexidade e a contingência das relações sociais, tendo por função a integração e controle social ao lado de outros elementos constitutivos do sistema ${ }^{138}$.

O papel legitimador da ordem e o uso do direito de maneira repressiva para a integração social são marcas que se extraem do funcionalismo de Parsons, que, no entanto, não avança de maneira significativa na análise específica sobre o fenômeno jurídico. $\mathrm{O}$ olhar destinado para o direito pode ser considerado vago, abstrato e essencialmente conservador, pois é visto apenas sob o enfoque integrador da ordem existente. As relações do direito com a transformação social, bem como de sua sociologia de maneira geral com esta temática, é caracterizada por uma "sonora ausência" "139, de modo que o destaque dado à estabilidade e à integração social acabavam por esconder as contradições e conflitos existentes na sociedade na qual o direito está inserido.

$\mathrm{Na}$ sociologia funcionalista de Parsons, a norma jurídica é considerada um instrumento de estabilização social e meio de legitimação do poder constituído. Por sua vez, o injusto penal, como aponta Juarez Tavares, representaria uma forma de oposição ao controle social institucionalizado, uma verdadeira disfuncionalidade do sistema ${ }^{140}$.

O destaque para sua obra coincidiu com o período histórico de crescimento econômico estadunidense em meio à guerra fria, cujo conservadorismo político era patente. A partir dos anos de 1960, com a atmosfera de crítica social e de significativa atuação dos movimentos de contestação da ordem, o funcionalismo de Parsons passa a ser alvo de profundas críticas ${ }^{141}$, especialmente por privilegiar a face estrutural e funcional das relações sociais que viabilizaram a vigência histórica das instituições e a manutenção da ordem conservadora. Apesar das críticas e da perda de prestígio em sua terra natal, serviu de inspiração para a formação do funcionalismo sistêmico de Niklas Luhmann, objeto de constantes debates na contemporaneidade e aporte teórico fundamental para o objeto do presente trabalho.

\footnotetext{
${ }^{138}$ SORIANO, Ramón. Sociología del derecho, cit., p. 147.

${ }^{139}$ ibidem, p. 150.

${ }^{140}$ TAVARES, Juarez. Teoria do Injusto Penal. 3. ed. Belo Horizonte: Del Rey, 2003, p. 59.

${ }^{141}$ SORIANO, Ramón. Sociología del derecho, cit., p. 147.
} 


\section{3 - Niklas Luhmann e a teoria dos sistemas}

\subsection{1 - A influência do pensamento de Niklas Luhmann}

A corrente mais influente do funcionalismo sociológico na contemporaneidade é o intitulado funcionalismo sistêmico ou teoria dos sistemas, cujo principal expoente é o sociólogo alemão Niklas Luhmann.

Luhmann formou-se em direito em Freiburg no ano de 1949 e posteriormente iniciou sua carreira na administração pública alemã, que durou até 1962. No ano anterior iniciou seus estudos de sociologia em Harvard como aluno da figura mais influente do pensamento sociológico do Ocidente daquele momento: o funcionalista Talcott Parsons. Em 1968 se estabelece na cidade alemã de Bielefeld, onde se inaugurava a universidade local, cujo posto de professor catedrático foi por ele exercido até sua aposentadoria em 1993.

Durante todo seu percurso acadêmico, Luhmann dedicou-se a desenvolver uma completa teoria da sociedade ${ }^{142}$, o que foi construído sob a influência do funcionalismo, especialmente sob a vertente estrutural de Parsons, e da teoria geral dos sistemas, além da introdução de conceitos da biologia cognitiva e da cibernética. Sua teoria geral da sociedade foi tão ampla que ultrapassou os limites da sociologia e exerce influência nos mais variados campos do conhecimento humano.

Dentre os diversos subsistemas que compõem a sociedade em sua teoria, o direito foi um dos que encerraram um estudo profundo e específico ${ }^{143}$. A influência de sua obra no

\footnotetext{
${ }^{142}$ Nesse sentido, registra que "a teoria geral dos sistemas sociais pretende abarcar todo o campo da sociologia e, por isso quer ser uma teoria sociológica universal." LUHMANN, Niklas. Sociedad y sistema: la ambición de la teoría. Barcelona: Ediciones Paidós, 1990, p. 47, tradução livre.

${ }^{143}$ Cf. LUHMANN, Niklas. Sociologia do Direito I. Trad. de Gustavo Bayer. Rio de Janeiro: Tempo Universitário, 1983; LUHMANN, Niklas. Sociologia do Direito II. Trad. de Gustavo Bayer. Rio de Janeiro: Tempo Universitário, 1985; LUHMANN, Niklas. El derecho de la sociedade. Trad. de Javier Nafarrete. Cidade do México: Universidad Iberoamericana, 2002; LUHMANN, Niklas. El derecho como un sistema social. In. GÓMEZ-JARA DÍEZ, Carlos(org.). Teoría de sistemas y derecho penal: fundamentos y posibilidades de aplicación. Bogotá: Universidad Externado de Colombia, 2007.
} 
direito brasileiro é crescente ${ }^{144}$, porém é no direito penal que seu alcance está profundamente consolidado, especialmente sob a vertente teórica inaugurada por Günther Jakobs e seguida por diversos penalistas ao largo do Ocidente, conhecida como o funcionalismo penal sistêmico.

\subsection{2 - A sociologia de Niklas Luhmann}

Para Luhmann, a grande questão a ser enfrentada pela sociologia consiste em descobrir o que é a sociedade, ponto de partida necessário para a elaboração de sua teoria dos sistemas. Como ciência da sociedade que é, a sociologia precisa partir de um conceito de sociedade para seu consequente desenvolvimento. Segundo a abordagem luhmanniana, a sociedade é o "sistema social omniabarcador que inclui em si todos os demais sistemas sociais." ${ }^{145}$ Conforme o conceito de sociedade do sociólogo alemão, só pode existir uma sociedade, o que implica que seu conceito de sociedade se identifique com o de sociedade mundial $^{146}$.

Luhmann assume, desde o princípio, uma peculiaridade singular em sua teoria no que se refere à relação entre indivíduo e sociedade. Ao contrário dos pensadores da sociologia tradicional, que assumem como pressuposto, cada um a seu modo, a ligação entre o indivíduo e a sociedade, o sociólogo sistêmico assume uma peculiar posição diante

\footnotetext{
${ }^{144}$ Por exemplo, cf. CAMPILONGO, Celso Fernandes. O direito na sociedade complexa. 2. ed. São Paulo, Saraiva, 2011; CAMPILONGO, Celso Fernandes. Interpretação do direito e movimentos sociais. Rio de Janeiro: Elsevier, 2012; GUERRA FILHO, Willis Santiago. Autopoiese no direito na sociedade pósmoderna. Porto Alegre: Livraria do Advogado, 1997; NEVES, Marcelo. Entre Têmis e Leviatã: uma relação difícil. São Paulo: Martins Fontes, 2006; ROCHA, Leonel Severo; SCHWARTZ, Germano; CLAM, Jean (orgs.). Introdução à teoria do sistema autopoiético do direito. Porto Alegre: Livraria do Advogado, 2005; VILLAS-BÔAS FILHO, Orlando. O direito na teoria dos sistemas de Niklas Luhmann. São Paulo: Max Limonad, 2006; VILLAS-BÔAS FILHO, Orlando. Teoria dos sistemas e o direito brasileiro. São Paulo: Saraiva, 2009.

${ }^{145}$ LUHMANN, Niklas. La sociedad de la sociedad. Trad. de Javier Nafarrete. Cidade do México: Herder, 2007 , p. 55, tradução livre.

${ }^{146}$ Nesse sentido aponta o autor: "A precisão de que a sociedade é um sistema social omniabarcador traz como consequência que para cada comunicação com capacidade de ligação haja apenas um sistema único de sociedade. No plano meramente fático podem existir diversos sistemas de sociedade, da mesma maneira em que antes se falava de um grande número de mundos. Mas se existissem estas sociedades, estariam sem relação comunicativa; ou melhor, na perspectiva de cada uma delas, uma comunicação com as outras sociedades seria impossível ou não teria consequências.” ibidem, p. 108, tradução livre.
} 
da referida relação. A sociedade, para o autor, não seria composta de indivíduos, ou mesmo da soma das manifestações individuais, mas de certas estruturas gerais nas quais os indivíduos são desconectados. Dessa maneira, o autor sustenta que o funcionamento geral da sociedade independe das relações intersubjetivas e se realiza de modo diverso das relações entre os indivíduos ${ }^{147}$. O modelo de sociedade carente de um modelo antropológico levou a que Ignacio Izuzquiza a caracterizasse como "sociedade sem homens" do mundo pós-industrial ${ }^{148}$.

A negação da subjetividade ${ }^{149}$ na formação da sociedade aponta para a sua constituição a partir de outros elementos: os sistemas sociais. A sociedade possui um processo de funcionamento completamente distinto da vida dos indivíduos, de maneira a constituir propriamente um corpo estruturado com uma densa racionalidade interna e lógica particular, de modo a culminar em um verdadeiro sistema social.

A sociedade abarca um conjunto de sistemas sociais específicos, com particularidades, funcionamento e lógicas de reprodução próprias. Luhmann distingue os sistemas em quatro tipos, correspondentes às máquinas, aos seres vivos, aos indivíduos e à sociedade. Os dois últimos são os que mais interessam às ciências sociais, sendo o sistema correspondente aos indivíduos - ou psíquico - vinculado ao pensamento ou consciência, enquanto o sistema social diferencia-se pela comunicação, seu elemento central. Um sistema social é todo sistema que produz comunicação como elemento básico para reproduzir-se a si mesmo ${ }^{150}$. Um sistema social é um sistema funcional de comunicação ${ }^{151}$ que se situa dentro do sistema que a todos abarca: a sociedade. Os sistemas sociais específicos, como o direito, a economia, a religião, a política, a arte e a ciência, por

\footnotetext{
${ }^{147}$ Nesse sentido, cf. MASCARO, Alysson Leandro. Lições de Sociologia do Direito, cit., p. 118.

148 "Se trata do rechaço que Luhmann faz de duas categorias centrais da tradição sociológica: o rechaço do conceito antropológico de homem como componente da sociedade e o rechaço do conceito de ação como elemento central de análise da sociologia. O sujeito humano é, para Luhmann, um sistema que não faz parte da sociedade, senão que se encontra no entorno dos sistemas sociais. E a ação deve ser substituída pelo conceito de comunicação para fundar uma adequada teoria da sociedade." IZUZQUIZA, Ignacio. La sociedad sin hombres. Niklas Luhmann o la teoría como escándalo. 2. ed. Barcelona: Anthropos Editorial, 2008, p. 230, tradução livre.

${ }^{149}$ A afirmação, contudo, deve ser contextualizada, conforme aponta Ana Elisa Liberatore Silva Bechara: "Isso não significa que a sociedade poderia existir mesmo que não existissem indivíduos; esses são seu pressuposto necessário. Mas os indivíduos não formam parte dos sistemas sociais, senão de seu meio (Umwelt). Portanto, nenhum indivíduo pertence por completo, como identidade total, a um sistema. Isso não significa minimizar a importância do homem para a sociedade, já que os sistemas não existem no vazio." BECHARA, Ana Elisa Liberatore Silva. Bem jurídico-penal. São Paulo: Quartier Latin, 2014, p. 289.

${ }^{150}$ RITZER, George. Teoría Sociológica Moderna, cit., p. 241.

${ }^{151}$ Cf. CAMPILONGO, Celso Fernandes. Interpretação do direito e movimentos sociais, cit., p. 43.
} 
exemplo, são o específico objeto de estudo da sociologia, que deve compreender o particular modo de funcionamento dos referidos sistemas autônomos.

A sociologia de Luhmann é fragmentária ${ }^{152}$, no sentido de que sua preocupação principal está na compreensão do funcionamento de cada sistema social autônomo, ao contrário de outras vertentes sociológicas que produzem uma análise social a partir da totalidade. No funcionalismo sistêmico, cada sistema particular deve ser compreendido a partir de seu conteúdo e desenvolvimento próprio, de modo que se torna crucial compreender o que compõe propriamente cada um desses sistemas abarcados pelo todo social.

A chave para compreender o sentido de um sistema social na sociologia de Luhmann está na diferenciação entre um sistema e seu entorno ou ambiente ${ }^{153}$. A diferença entre a sociedade e seu ambiente é, ao mesmo tempo, uma forma de distinção e de definição do que constitui a sociedade. Os sistemas sociais que formam a sociedade estão imersos em um sistema complexo em que se relacionam com diversos outros, como, por exemplo, a relação inegável entre o direito e a política ou a economia. Todavia, os sistemas citados não se confundem e a distinção entre aquilo que os constituem e aquilo com o qual se relacionam e que não são próprios de si, ou seja, entre o sistema propriamente considerado e seu entorno, é fundamental para compreender o particular modo de funcionamento de cada sistema social.

A diferença entre o sistema e seu entorno está no grau de complexidade, uma vez que o sistema é sempre menos complexo do que o ambiente externo. As interferências do entorno devem ser de tal modo provisórias e limitadas para que não supere o sistema social de tal maneira a compor uma nova lógica autônoma e formação de outro sistema. Por isso, ainda que não possam ser tão complexos quanto seu entorno, os sistemas devem desenvolver subsistemas e estruturas para uma melhor relação com o entorno, caso contrário poderão ser superados pela complexidade deste. Um dos grandes objetivos da sociologia luhmanniana foi construir um aporte teórico que reduzisse a complexidade da sociedade contemporânea, entendida como a totalidade de possibilidades de experiência e

\footnotetext{
${ }^{152}$ Nesse sentido, MASCARO, Alysson Leandro. Lições de Sociologia do Direito, cit., p. 120.

${ }^{153}$ Cf. LUHMANN, Niklas. La sociedad de la sociedade, cit., p. 40 e ss.
} 
de ações possíveis na vida social ${ }^{154}$, ante a inviabilidade de atingir tal escopo através do conhecimento desenvolvido pelas escolas sociológicas que o antecederam ${ }^{155}$.

Por outro lado, como sistemas de comunicação que são, a forma de diferenciação entre sistema e entorno se baseia em operações de comunicação, ou seja, os sistemas se diferenciam a partir de suas próprias formas de comunicação ${ }^{156}$. No caso da sociedade, por exemplo, tudo que não é parte da sua comunicação configura seu entorno.

Os sistemas sociais são descritos como estruturas fechadas, ou seja, que não são abertos para o entorno da sociedade. A clausura dos sistemas aponta para a ausência de relação direta entre estes e o seu entorno. O fechamento operativo do sistema e a consequente ausência de relação direta com o ambiente exterior faz com que as relações do sistema se estabeleçam com suas representações do entorno ${ }^{157}$. O sistema comunicativamente fechado produz comunicação mediante comunicação ${ }^{158}$.

A clausura dos sistemas sociais revela uma outra característica da sociologia de Luhmann, qual seja o caráter autorreferencial dos sistemas. É a partir da sua própria formação, funcionamento e instituições que o sistema extrai suas referências e lógica de manifestação e reprodução. Como decorrência das características da sociedade descrita pelo sociólogo alemão, fechada e autorreferencial, ganha destaque seu conceito de autopoiese.

Inspirado no conhecimento construído no âmbito da biologia, especialmente pelos trabalhos dos biólogos chilenos Humberto Maturana e Francisco Varela ${ }^{159}$, Luhmann desenvolveu o conceito de autopoiese para as ciências sociais. A etimologia da palavra

\footnotetext{
${ }^{154}$ Cf. LUHMANN, Niklas. Sociologia do Direito I, cit., p. 45.
}

${ }^{155}$ TRINDADE, André. Para entender Luhmann e o direito como sistema autopoiético. Porto Alegre: Livraria do Advogado, 2007, p. 16.

${ }^{156}$ Nesse sentido, cf. CAMPILONGO, Celso Fernandes. Interpretação do direito e movimentos sociais, cit., p. 44.

${ }^{157} \mathrm{Um}$ exemplo dessa relação é trazida por Ritzer: “(...) o sistema econômico supostamente responde às necessidades materiais e os desejos das pessoas; sem embargo essas necessidades e desejos influem no sistema econômico somente na medida em que podem ser representados em termos de dinheiro Como consequência disso, o sistema econômico responde bem às necessidades materiais e desejos das pessoas ricas, mas não tão bem às necessidades e os desejos das pessoas pobres." RITZER, George. Teoría Sociológica Moderna, cit., p. 230, tradução livre.

158 "A sociedade é um sistema comunicativamente fechado: produz comunicação mediante comunicação. Sua dinâmica consiste em que a comunicação atua sobre a comunicação e, neste sentido: transforma permanentemente as distinções e indicações atuais, mas não configura nunca o entorno exterior: falando não podem se acomodar as coisas, pensando não podem se distanciar nem se modificar." LUHMANN, Niklas, op. cit., p. 68 , tradução livre.

${ }^{159}$ Cf. MATURANA, Humberto; VARELA, Francisco. A árvore do conhecimento: as bases biológicas do conhecimento humano. Trad. Jonas Pereira dos Santos. Editorial Psy II: Campinas, 1995. 
autopoiese leva à noção de autocriação ${ }^{160}$. A teoria desenvolvida pelos mencionados biólogos defende que a estrutura de um ser vivo é um sistema autopoiético, ou seja, que se constitui a partir de um processo mediante o qual seu sistema se reproduz através da relação com seu próprio meio. Os adeptos do funcionalismo sistêmico chegam a assentar que ao ligar o sistema biológico ao sistema social, a teoria sociológica de Luhmann fica quase imune a refutações ${ }^{161}$. Todavia, é preciso observar que a concepção luhmanniana de autopoiese afasta-se do modelo biológico na medida em que separa os sistemas sociais e psíquicos dos orgânicos não constituintes de sentido ${ }^{162}$.

Luhmann importará o conceito de autopoiese para a sociologia para caracterizar os sistemas sociais e sua forma de evolução e reprodução. Para o autor, "os sistema autopoiéticos são aqueles que por si mesmos produzem não só suas estruturas, mas

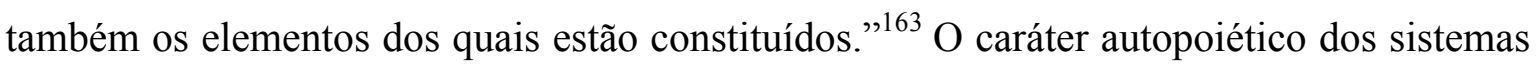
sociais é uma decorrência lógica da constituição fechada e autorreferencial dos mesmos sistemas, de modo a configurar uma estrutura própria dotada de um juízo de autossuficiência.

Os sistemas autopoiéticos estão auto-organizados em dois sentidos fundamentais: organizam seus próprios limites e produzem suas estruturas internas ${ }^{164}$. A partir da distinção entre o que compõe o sistema e o que faz parte do entorno, os sistemas sociais organizam seus próprios limites, que são determinados pela sua auto-organização. E dentro desses limites produz suas próprias estruturas constitutivas. Desta forma, assim como a reprodução dos seres vivos descrita pelos biólogos chilenos, os sistema sociais também se reproduzem e se desenvolvem pelos seus próprios elementos constitutivos e dentro de seus próprios limites. Apesar da sua clausura e da falta de conexão direta com o entorno, os sistemas sociais devem permitir que o entorno perturbe suas representações internas, mas sem que isso possa representar sua modificação ou superação.

A sociedade para Luhmann é, pois, um sistema autopoiético que produz seus próprios elementos básicos, estabelece seus próprios limites e estruturas, além de ser autorreferencial e fechado. O elemento fundamental da sociedade é a comunicação

\footnotetext{
${ }^{160}$ Cf. NEVES, Marcelo. Entre Têmis e Leviatã, cit., p. 60.

${ }^{161}$ Nesse sentido, cf. TRINDADE, André. Para entender Luhmann e o direito como sistema autopoiético, cit., p. 69.

${ }^{162}$ Nesse sentido, cf. NEVES, Marcelo, op. cit., p. 61.

${ }^{163}$ LUHMANN, Niklas. Sociologia do Direito I, cit., p. 44-45, tradução livre.

${ }^{164}$ RITZER, George. Teoría Sociológica Moderna, cit., p. 228.
} 
produzida em seu interior. Os participantes da sociedade a ela se referem através da comunicação, o que faz com que o indivíduo só tenha relevância para a sociedade na medida em que participe desta comunicação, uma vez que para o sociólogo alemão tudo o que não é comunicação faz parte do entorno da sociedade. Nesse sentido, aponta George Ritzer que "o indivíduo como organismo biológico e o indivíduo como consciência não formam parte da sociedade, são externos a ela", o que leva à estranha ideia de que o indivíduo não faz parte da sociedade ${ }^{165}$.

A sociedade fundada em um sistema de comunicação enfrentará o problema descrito por Luhmann como "dupla contingência" e criará estruturas sociais para lidar com essa questão, de modo a prover a manutenção do sistema social. A dupla contingência refere-se ao fato de que toda comunicação deve levar em consideração o modo como é recebida, o que depende, dentre outros fatores, da opinião e formação do receptor da comunicação. Isso forma um "círculo impossível”, uma vez que o receptor depende do comunicador e o comunicador do receptor da comunicação ${ }^{166}$.

Para resolver o problema da dupla contingência, Luhmann aponta para o fato de que, em sociedade, sempre temos informações sobre as expectativas dos demais em virtude das próprias estruturas e funcionamento social. A partir dessas expectativas são desenvolvidas normas e expectativas de rol e papéis sociais para interpretação das comunicações. Pode ocorrer o fato da não observação ou aceitação das normas e papéis sociais, o que eventualmente acarretará a sua mudança ou uma reação. Todavia, a sociedade, de maneira alguma, poderá prescindir das expectativas, justamente por conta do problema da dupla contingência.

As interações do processo de comunicação representam acontecimentos de processos sociais em marcha na evolução da sociedade. A sociedade deve garantir a possibilidade de conexão entre as comunicações passadas e futuras para não deixar de existir. Para tanto deve desenvolver as estruturas que permitam a comunicação social por meio da autopoiese dos sistemas sociais ${ }^{167}$, de modo a superar a dupla contingência e tornar prováveis as comunicações para a evolução desses sistemas.

\footnotetext{
${ }^{165}$ RITZER, George. Teoría Sociológica Moderna, cit., p. 231, tradução livre.

${ }^{166}$ RITZER, George, op. cit., p. 232.

${ }^{167}$ Nesse sentido aponta com clareza George Ritzer: “A comunicação é necessária porque cada um de nós tem um conjunto diferente de normas e desenvolvemos este conjunto próprio de normas porque a comunicação tem o problema da dupla contingência. Isto mostra como funciona a sociedade como um sistema autopoiético: a estrutura (os papéis, as normas institucionais e tradicionais) da sociedade cria os
} 
A evolução da sociedade para Luhmann não possui caráter teleológico, pois não está determinada por metas anteriormente definidas ou fins determinados ${ }^{168}$. Ao contrário, em seu pensamento a evolução apenas torna mais provável a improbabilidade da evolução. Apoiado no modelo neodarwinista de evolução ${ }^{169}$, esta constitui um conjunto de processos com três funções, quais sejam de variação, seleção e estabilização ${ }^{170}$. A variação ${ }^{171}$ é um processo de erros e acertos que implicará em uma comunicação inesperada. Diante de um problema concreto, desenvolvem-se várias soluções para enfrentá-lo, que podem ser eficazes ou não ${ }^{172}$. Diante da variação, é preciso selecionar ${ }^{173}$ a solução que seja capaz de construir e condensar as expectativas sociais. Por fim, o processo de evolução alcança um fim temporal quando se obtém a estabilização ${ }^{174}$ do sistema social de acordo com a nova solução eleita.

Luhmann abandona a explicação da sociedade como um processo linear, no qual esta evoluiria de estágios inferiores a superiores, em uma cadeia historicamente evolutiva de superação de fases menos avançadas ou formas de dominação que seriam substituídas por modelos sociais avançados nos quais vigoraria a liberdade plena dos indivíduos. A sociologia luhmanniana não trabalha com interpretações ou previsões futuras a serem

elementos (a comunicação) de a sociedade e estes elementos criam a estrutura de maneira que, como em todo sistema autopoiético, o sistema constitui seus próprios elementos.” RITZER, George. Teoría Sociológica Moderna, cit., p. 233, tradução livre.

${ }^{168}$ NEVES, Marcelo. Entre Têmis e Leviatã, cit., p. 5.

${ }^{169}$ Cf. LUHMANN, Niklas. Sociologia do Direito I, cit., p. 327.

${ }^{170}$ Cf. NEVES, Marcelo, op. cit., p. 6 e ss.

171 “Através da variação se modificam os elementos do sistema, quer dizer, as comunicações. A variação consiste em uma reprodução desviante de elementos por elementos do sistema. Em outras palavras, consiste em uma comunicação inesperada, surpreendente.” idem, tradução livre.

${ }^{172}$ RITZER, George, op. cit., p. 234.

173 “A seleção se refere às estruturas do sistema, ou seja, às expectativas que guiam à comunicação. Com base na comunicação desviante, a seleção elege as referências de sentido que tenham valor de formar estruturas, idôneas para o uso repetido, capazes de construir e condensar expectativas. A seleção, logo, desfaz, atribuindo o desvio às circunstâncias, ou as abandonando ao esquecimento, ou as rechaçando explicitamente - aquelas novidades que não parecem ser aptas para servir de estruturas ou para dar rumo à comunicação posterior.” LUHMANN, Niklas, op. cit., p. 327, tradução livre.

174 “A estabilização se refere ao estado do sistema que está evoluindo depois de uma seleção que resultou positiva ou negativa. Aqui, sobretudo, se trata do sistema mesmo da sociedade em relação com seu entorno. Pense-se, por exemplo, no primeiro desenvolvimento da economia agrária com consequências que deviam ser 'capazes de formar sistema' no sistema social da sociedade. Ou no afastamento de uma agriculturização — por razões ecológicas ou por outras - que leva logo ao aparecimento de 'povos nômades' à margem de sociedades campesinas já desenvolvidas politicamente. No curso da evolução posterior da sociedade, a função de estabilização se desloca cada vez mais a sistemas parciais da sociedade, que devem se afirmar no entorno interno da sociedade. Se trata, e última instância, do problema da sustentabilidade da diferenciação de sistema da sociedade." idem, tradução livre. 
alcançadas, mas com categorias de probabilidade e improbabilidade, nas quais o acaso possui um papel de destaque ${ }^{175}$.

A busca pela ordem na complexidade é o objetivo central de um sistema social. Os sistemas sociais são estudados a partir de suas funções e na medida em que tais funções contribuem para a conservação da ordem na sociedade.

As características gerais da sociedade em Luhmann moldam também os sistemas que compõem o todo social, como o direito. Assim como diversos outros sistemas sociais, o direito foi objeto de estudos específicos do sociólogo alemão, cuja influência é crescente em diversos ramos do direito.

\subsection{3 - O direito em Niklas Luhmann}

Na sociologia sistêmica de Luhmann, o direito é um dos subsistemas que compõem o todo da sociedade. Como os demais, é igualmente autorreferencial, fechado, autopoiético e composto por um conjunto de comunicações que o caracteriza ${ }^{176}$, cujo referencial é a questão da legalidade. Como sistema social, possui uma racionalidade própria determinada por seus referenciais e elementos constitutivos que manejam operações e esquemas particulares.

O núcleo do sistema jurídico está na diferenciação entre o lícito e o ilícito. O direito produz expectativas e com isso exerce o papel de redutor das complexidades características da sociedade contemporânea. Assim, as expectativas produzidas pelo sistema do direito institucionalizam os comportamentos sociais e são generalizados pela norma jurídica, que, embora seja elaborada em um processo que se inicia fora do direito, adquire o status de norma jurídica após a seleção realizada pelo sistema jurídico próprio ${ }^{177}$.

\footnotetext{
${ }^{175}$ Cf. NEVES, Marcelo. Entre Têmis e Leviatã, cit., p. 5.

${ }^{176}$ Assim como a sociedade, o sistema do direito também não é comporto por indivíduos, senão por comunicações. Por isso, Alysson Leandro Mascaro observa criticamente que sequer "o jurista como pessoa, que é uma das expressões mais típicas da ferramenta do sujeito" faz parte da sociologia do direito de Luhmann. MASCARO, Alysson Leandro. Lições de Sociologia do Direito, cit., p. 124.

${ }^{177}$ Cf. BECHARA, Ana Elisa Liberatore Silva. Bem jurídico-penal, cit., p. 286.
} 
A complexidade do todo social é reduzida pelo sistema jurídico a partir da codificação binária do lícito/ilícito na qual as questões sociais passam a ser submetidas. A partir daí, "na rede de comunicações da sociedade, o direito se especializa na produção de um tipo particular de comunicação que procura garantir expectativas de comportamento assentadas em normas jurídicas." 178 O direito age, desta forma, como um filtro redutor dos conflitos surgidos em outros sistemas sociais com a função de garantir uma ordem social.

O processo social comunicativo acaba por formar, inevitavelmente, expectativas compartilhadas entre os indivíduos, de modo que o direito terá como função primordial o respeito a essas expectativas vigentes na sociedade. Para tanto, a partir das expectativas sociais, o direito regula os padrões de comportamento que possibilite alguma previsibilidade de condutas como maneira de estabelecer a ordem social.

O direito, como sistema social próprio, também segue a lógica dos demais sistema sociais na sociologia de Luhmann, qual seja a de redução da complexidade social. Tal função reservada ao direito desenvolve-se fundamentalmente com a consideração de expectativas comportamentais compartilhadas que reduzem a complexidade do ambiente de maneira a estabelecer a ordem social vigente. A despeito de constituir um sistema fechado e autorreferencial, o direito recebe interferências e irritações do seu entorno, mas as apreende segundo o seu referencial característico e realiza uma operação redutora da complexidade. Do contrário haveria espaço para o caos e a desordem.

As comunicações que compreendem a sociedade estabelecem uma sequência concatenada de expectativas de comportamento que possibilitam o convívio pela existência de alguma previsibilidade dos comportamentos alheios. É em um contexto de incertezas e riscos que o direito exerce a sua função de redução da complexidade mediante a adoção de padrões de comportamentos.

A questão da dupla contingência ganha no direito uma importância capital, já que não basta a existência de expectativas apenas sobre comportamento, mas se torna necessário que se possa ter expectativas sobre as próprias expectativas alheias: expectativas de expectativas.

Para tanto, Luhmann diferencia em termos funcionais as expectativas em cognitivas e normativas. As expectativas cognitivas são aquelas que em caso de desapontamento são adaptadas à realidade, podendo gerar um aprendizado e a modificação da própria

${ }^{178}$ CAMPILONGO, Celso Fernandes. O direito na sociedade complexa, cit., p. 162. 
expectativa. Já as expectativas normativas não são abandonadas em caso de transgressão ${ }^{179}$, uma vez que sua frustração não pode ser assimilada como alternativa de comportamento aceitável, senão que deve ser negada como tal. No primeiro caso surge uma nova realidade sobre o fato, enquanto no segundo surge a necessidade de intervenção da norma jurídica de maneira contrafática ${ }^{180}$. Diante dessa distinção, Luhmann define as normas como "expectativas de comportamento estabilizadas em termos contrafáticos."181

As normas jurídicas representam, portanto, a expressão da confiança depositada em expectativas que, uma vez frustradas, acarretam a coação da norma para sua estabilização. Dessa maneira, cumpre ao direito como sistema social estabilizar as expectativas e as comunicações como maneira de manter a ordem social ${ }^{182}$. Dentro do sistema jurídico, só poderão ser considerados válidos as ações e procedimentos que estejam de acordo com os referenciais normativos. O sistema jurídico está composto de normas jurídicas e em um sistema estruturado hierarquicamente, de modo que aquilo que não puder ser qualificado como lícito ou ilícito não terá sequer relevância para o sistema jurídico.

Por outro lado, são as próprias normas jurídicas que determinarão a forma de sua reprodução, uma vez que o fechamento do sistema do direito determina que ele próprio é o responsável pela sua criação. Como sistema autopoiético, os pressupostos para a mudança do direito serão dados pelo próprio direito, que é estruturado em um sistema hierárquico de normas.

Uma outra decorrência do caráter autopoiético do direito é seu fechamento também na questão da legitimidade. A legitimidade do direito é buscada dentro do próprio sistema jurídico por meio de uma ficção legal da validade de suas normas, sem que para tanto se

\footnotetext{
${ }^{179}$ LUHMANN, Niklas. Sociologia do Direito I, cit., p. 56.

180 "'Dessa forma, as expectativas cognitivas são caracterizadas por uma nem sempre consciente disposição de assimilação em termos de aprendizado, e as expectativas normativas, ao contrário, caracterizam-se pela determinação em não assimilar os desapontamentos. O caso de desapontamento é previsto como possível - é sabido que o mundo é complexo e contingente, e que, portanto, os outros podem agir de forma inesperada mas de antemão isso é considerado irrelevante para a expectativa." ibidem, p. 56.

${ }^{181}$ E continua aduzindo que "seu sentido implica na incondicionalidade de sua vigência na medida em que a vigência é experimentada, e portanto também institucionalizada, independentemente da satisfação fática ou não da norma. O símbolo do "dever ser" expressa principalmente a expectativa dessa vigência contrafática, sem colocar em discussão essa própria qualidade - aí estão o sentido e a função do "dever ser”. ibidem., p. 57.

${ }^{182}$ Nesse sentido, asseveram André-Jean Arnaud e Dalmir Loper Jr que "o sistema estabiliza as expectativas e não o comportamento, logo os sistemas sociais só podem estabilizar comunicações, criar sobre elas expectativas do que pode ou não ser esperado, de tal forma que entre as comunicações aparece uma determinada ordem.” ARNAUD, André-Jean; LOPES JR., Dalmir (orgs.). Niklas Luhmann: do sistema social à sociologia jurídica. Rio de Janeiro: Lumen Juris, 2004, p. 16.
} 
busque um referencial axiológico ou externo ao sistema social representado pelo direito ${ }^{183}$. O referencial de legitimidade do direito é o próprio sistema jurídico, fechado e autorreferencial, que acaba por atribuir uma lógica circular à sua justificação social.

Por outro lado, o papel estabilizador de expectativas para garantir o futuro das comunicações gera a necessidade da simbolização de toda a ordem jurídica, que pode ser compreendida como uma estrutura de expectativas simbolicamente generalizadas ${ }^{184}$. A referida simbolização constitui-se em verdadeira condição para estabilização do sistema, o que pode ser verificado no papel atribuído à pena no contexto da teoria da prevenção geral positiva, cuja influência de Luhmann se faz sentir em uma de suas vertentes mais destacadas.

O direito penal, portanto, segue igualmente a lógica sistêmica descrita, respeitadas as suas peculiaridades como campo do direito caracterizado pela sanção mais grave do sistema jurídico. No que concerne a este ramo do direito, o funcionalismo sistêmico recebe um desenvolvimento próprio e apurado por parte da doutrina, especialmente a partir do estudo desenvolvido por Günther Jakobs.

\footnotetext{
${ }^{183}$ No mesmo caminho é a análise de Jean Clam: "A consequência é a autonomização total da "legitimidade" jurídica (Rechtsgeltung), que não pode, então, ser atribuída a outra coisa que não ao sistema jurídico em si mesmo, tornando-se o único símbolo de sua unidade. Assim estabelece-se para Luhmann um fato de alcance maior: a legitimação do sistema jurídico é adquirida pela ficção legal de uma validade positiva de suas normas - mantidas fora de toda referencia axiológica." CLAM, Jean. A autopoiese no Direito. In. ROCHA, Leonel Severo; SCHWARTZ, Germano; CLAM, Jean (orgs.). Introdução à teoria do sistema autopoiético do direito. Porto Alegre: Livraria do Advogado, 2005, p. 120.

${ }^{184}$ Cf. TAVARES, Juarez. Teoria do Injusto Penal, cit., p. 64.
} 


\section{CAPÍTULO 3 - A TEORIA DA PREVENÇÃO GERAL POSITIVA NO PENSAMENTO DE GÜNTHER JAKOBS}

SUMÁRIO: 3. A teoria da prevenção geral positiva no pensamento de Günther Jakobs - 3.1. Hans Welzel e a prevenção geral positiva - 3.2. Günther Jakobs e a prevenção geral positiva - 3.2.1. Culpabilidade e Prevenção: a primeira fase do pensamento de Günther Jakobs 3.2.2. Sociedade, norma e pessoa em uma teoria de um direito penal funcional: a segunda fase do pensamento de Günther Jakobs - 3.2.3. A pena estatal: a consolidação da teoria da pena de Günther Jakobs - 3.3. O nascimento do direito penal do inimigo - 3.4. A prevenção geral positiva limitadora de Winfried Hassemer e Claus Roxin - 3.5. Prevenção geral positiva em Günther Jakobs: síntese conclusiva.

A teoria da prevenção geral positiva não foi elaborada de maneira definitiva em um único trabalho de Jakobs. Sua construção deu-se em um verdadeiro percurso teórico, no qual, além da marcante influência do funcionalismo sociológico, o autor recebeu o influxo filosófico e jurídico de maneira variada ao longo do tempo, passando pelos ensinamentos de Hans Welzel e pela filosofia hegeliana até conceber o formato contemporâneo da teoria tal qual é difundida no debate das ciências criminais.

\section{1 - Hans Welzel e a prevenção geral positiva}

Após o fim da Segunda Guerra Mundial, o direito penal passou por profundas transformações, principalmente na Alemanha, berço do nazismo e palco de atrocidades que deixaram marcas indeléveis desde aquele período histórico. No contexto de reconstrução teórica do direito penal no âmbito do Estado de Direito que renascia, um dos teóricos de maior importância foi Hans Welzel. 
Elaborado inicialmente nos princípios da década de 1930, o finalismo de Welzel se consolida como a grande referência teórica do direito penal no período posterior à Guerra. A perspectiva ontológica, com a elaboração dogmática a partir da consideração das estruturas lógico-objetivas, possibilitou profundas transformações na teoria do delito. No entanto, suas reflexões sobre o sentido e a missão do direito penal na sociedade, embora não tão exploradas quanto seu aporte à teoria do delito, também revelaram a originalidade do pensamento do professor finalista.

A elaboração teórica de Welzel parte da distinção entre as formas de valoração da conduta humana. Conforme aponta o autor alemão, toda ação humana pode ser valorada conforme o resultado que origina (valor de resultado ou material), ou independentemente dele, conforme o sentido da atividade como tal (valor da ação). Ao direito penal incumbe impedir o desvalor do resultado mediante a punição do desvalor do ato, com o objetivo de assegurar a vigência dos valores de ação ético-sociais de caráter positivo ${ }^{185}$.

A maior relevância atribuída ao conteúdo do desvalor do ato em contraponto ao desvalor do resultado é uma característica do novo sistema de delito estruturado sobre a teoria da ação final, que a partir da consideração da intencionalidade como elemento central da atuação humana, com antecipação de metas e eleição de meios, tem como consequência um juízo de valor mais centrado na ação ${ }^{186}$. A ação que produz a infração a um dever ganha maior relevância jurídico-penal do que o causação de um resultado, motivo pelo qual pode-se dizer que, sob a perspectiva de Welzel, são mais importantes as condutas do que suas consequências ${ }^{187}$.

Para Welzel, a missão central do direito penal é assegurar a vigência inquebrantável dos valores de ação conforme o direito, que constituem o substrato ético-social positivo das normas jurídico-penais ${ }^{188}$. Tal objetivo é alcançado mediante a atuação do direito penal

\footnotetext{
${ }^{185}$ WELZEL, Hans. Derecho Penal Alemán. Parte General. 11. ed. Trad. Juan Bustos Ramírez e Sérgio Yáñez Pérez. Santiago de Chile: Editorial Jurídica de Chile, 1970, p. 11-12.

186 “Assim, o conteúdo material do delito não será a mera tutela de bens jurídicos, e sim a manutenção da atitude ético-social correta, contrariada pelo agente. Sinteticamente, o delito corresponde fundamentalmente ao desvalor da conduta (lesão de dever), e não do desvalor do resultado (lesão de bem jurídico)." BECHARA, Ana Elisa Liberatore Silva. Bem jurídico-penal, cit., p. 283.

${ }^{187}$ SALVADOR NETTO, Alamiro Velludo. Finalidades da pena. Conceito material de delito e sistema penal integral. São Paulo: Quartier Latin, 2009, p. 75.

${ }^{188}$ WELZEL, Hans, op. cit., p. 12.
} 
e a consequente punição das ações desleais à consciência jurídica, de modo a criar uma tendência comportamental constante com a defesa dos referidos valores ético-sociais ${ }^{189}$.

A proteção de bens jurídicos e a prevenção geral negativa seriam apenas consequências secundárias da aplicação do direito penal, uma vez que, em geral, quando este efetivamente atua "já é tarde demais"190, pois os bens jurídicos já foram violados. Desta forma, para além da proteção de bens jurídicos concretos ${ }^{191}$, a função fundamental do direito penal é assegurar a vigência dos valores ético-sociais que formam a consciência jurídica e o sustentáculo do Estado e da sociedade. Trata-se de um função positiva do direito penal, que estimularia o comportamento de fidelidade ao direito e, consequentemente, garantiria a vigência dos valores fundamentais para a vida em sociedade $^{192}$.

Na verdade, para Welzel a única maneira de assegurar a proteção de bens jurídicos de forma permanente e eficaz se dá por meio da garantia dos valores ético-sociais que permeiam a conduta humana. $\mathrm{O}$ direito penal, portanto, desempenha um papel social positivo e permanente, que culminaria na proteção dos bens jurídicos por meio do exercício de fidelidade ao direito ${ }^{193}$.

Por outro lado, as raízes do que se entende hodiernamente por prevenção geral positiva estão indubitavelmente no pensamento original de Hans Welzel ${ }^{194}$, que coloca à frente de qualquer outro objetivo do direito penal a missão de modelar e reforçar eficazmente o juízo ético e a consciência jurídica dos cidadãos ${ }^{195}$. Cumpre ao direito penal

\footnotetext{
${ }^{189}$ SALVADOR NETTO, Alamiro Velludo. Finalidades da pena, cit., p. 77.

${ }^{190}$ WELZEL, Hans. Derecho Penal Alemán, cit., p. 13.

${ }^{191}$ Sobre o valor do bem jurídico na obra de Hans Welzel, cf. BECHARA, Ana Elisa Liberatore Silva. Bem jurídico-penal, cit, p. 114 e ss.

192 "Mais essencial que a proteção de determinados bens jurídicos concretos é a missão de assegurar a real vigência (observância) dos valores de ação da consciência jurídica; estes constituem o fundamento mais sólido que sustenta o Estado e a sociedade. A mera proteção de bens jurídicos tem só um fim preventivo, de caráter policial e negativo. Pelo contrário, a missão mais profunda do Direito Penal é a natureza ético-social e de caráter positivo.” WELZEL, Hans, op. cit., p. 13, tradução livre.

${ }^{193}$ Nesse sentido, aponta o autor que "ante o benefício permanente que significa a consciência do cidadão constantemente fiel ao Direito, o mero proveito ou dano atual passa para o segundo plano com relação aos valores de ação." ibidem, p. 14, tradução livre.

${ }^{194}$ No mesmo sentido, cf. SALVADOR NETTO, Alamiro Velludo, op. cit., p. 78.

195 "Ao tornar patente ante todos a validez inquebrantável dos elementares deveres ético-sociais, proscrevendo e castigando sua lesão, modela e reforça eficazmente o juízo ético e a consciência jurídica dos cidadãos.” WELZEL, Hans, op. cit., p. 17, tradução livre.
} 
orientar os cidadãos para que incorporem em sua consciência os valores ético-sociais e, dessa maneira, orientem seus projetos de ação ${ }^{196}$.

Contudo, as ideias de Welzel sofreram duras críticas. Conforme aponta com razão Juarez Tavares, "sendo imanente à consciência de cada pessoa a obediência a um dever geral de respeito a esses valores ético-sociais, a proteção jurídica se confunde com a proteção moral". Por outro lado, é igualmente pertinente a crítica que recebe Welzel quanto à falta de definição dos aludidos valores ético-sociais, que refletem "um raciocínio vazio e circular" ${ }^{\prime 197}$ por se centralizar em uma categoria puramente formal. A vagueza e abstração do conceito utilizado franqueia uma arriscada possibilidade de utilização do direito penal como instrumento ideológico de opressão, conforme a opção política adotada pelos detentores do $\operatorname{poder}^{198199}$.

\section{2 - Günther Jakobs e a prevenção geral positiva}

A construção da teoria da prevenção geral positiva assume três fases determinantes ao longo da produção teórica de Jakobs. Desde a influência de Hans Welzel até a apropriação da filosofia hegeliana, Jakobs apura sua teoria a partir de influências diversas e respostas a críticas dirigidas pela doutrina penal. Constantemente permeado pelos conceitos do funcionalismo sistêmico, o percurso desenvolvido pelo autor mostra a importância dos influxos teóricos recebidos para forjar a sua teoria da pena, além de permitir a exposição clara do seu atual significado.

\footnotetext{
${ }^{196}$ Cf. TAVARES, Juarez. Teoria do Injusto Penal, cit., p. 192.

${ }^{197}$ BECHARA, Ana Elisa Liberatore Sila. Bem jurídico-penal, cit., p. 283.

${ }^{198}$ Nesse sentido, aponta Juarez Tavares que "basta que se imprima aos valores ético-sociais conteúdos semelhantes ao sadio sentimento do povo, ou à consciência coletiva, ou à vontade geral da nação, ou à moralidade pública, para que se instaure um regime de terror, sem fronteiras e ontologicamente legitimado." TAVARES, Juarez, op. cit., p. 194.

${ }^{199}$ Sobre as origens ideológicas de seu pensamento, cf. FROMMEL, Monika. Los Orígenes ideológicos de la teoría final de la acción de Welzel. Anuario de Derecho Penal y Ciencias Penales. Fascículo II, MayoAgosto 1989, pp. 621-632.
} 


\subsection{1 - Culpabilidade e Prevenção: a primeira fase do pensamento de Günther Jakobs}

Em 1976, Jakobs publica o trabalho que constitui sua primeira abordagem mais profunda sobre a teoria da pena. Intitulado Culpabilidade e Prevenção ${ }^{200}$, o artigo relaciona o conceito de culpabilidade com a ideia de prevenção geral positiva, sendo esta o verdadeiro fundamento da culpabilidade ${ }^{201}$.

Diretamente influenciado pela sociologia de Niklas Luhmann, Jakobs fundamenta a pena estatal na necessidade de confirmação da obrigatoriedade do ordenamento jurídico frente ao cidadão fiel ao direito. A pena deve ser imposta para manutenção do ordenamento com o fim de que se evite a perturbação de expectativas cuja legitimidade se encontra juridicamente garantida ${ }^{202}$.

Utilizando-se da classificação luhmanniana de expectativas cognitivas e normativas $^{203}$, o penalista alemão relaciona a função da pena à manutenção desta última categoria de expectativa social. Com efeito, a reação contrafática à violação da expectativa normativa demonstra a qualidade defeituosa do comportamento e a correção da expectativa que orienta os comportamentos humanos. "Se os fatos não se corresponderam com a expectativa normativa, tanto pior para os fatos" ${ }^{\text {"204 }}$, que são declarados defeituosos para que não sirvam como dados pelos quais as pessoas devam se orientar.

Do ponto de vista jurídico, os fatos defeituosos são imputados ao autor e a pena constitui a resposta estatal que reafirma a expectativa violada. A pena, desta forma, sujeita o comportamento que se imputa com uma consequência penal e "incrementa as possibilidades de que dito comportamento seja em geral aprendido como uma alternativa

\footnotetext{
${ }^{200}$ No original Schuld und Prävention. Tubingen: J. C. B. Mohr (Paul Siebeck), 1976. O presente trabalho utilizou a tradução espanhola Culpabilidad y prevención, In: Estudios de Derecho Penal. Tradução de Carlos J. Suárez González. Madrid: Ediciones de la Universidad Autónoma de Madrid y Editorial Civitas, 1997 , p.73 e ss.

201 ibidem, p. 78.

202 idem.

${ }^{203}$ A adoção da referida classificação, contudo, parece deturpar a proposta original de Luhmann, pois Jakobs considera as ambas as expectativas de maneira apriorística, ou seja, a partir de sua natureza correspondente, e não a partir da reação do indivíduo em relação ao seu desapontamento, como se apresenta na proposição do sociólogo alemão. Cf. BECHARA, Ana Elisa Liberatore Sila. Bem jurídico-penal, cit., p. 295.

${ }^{204}$ JAKOBS, Günther, op. cit., p. 79.
} 
de comportamento inaceitável”205. Acredita o autor que a desvaloração da alternativa de comportamento violador da expectativa normativa pode ser tão evidente que conduza a seu completo abandono como alternativa vivencial.

Assim, o autor emprega à prevenção geral não um sentido intimidatório, senão que a prevê como um exercício de fidelidade ao direito. A intimidação, ainda que desejável, seria apenas um dos possíveis efeitos suplementares do processo de reafirmação de expectativas sociais levada à cabo pela pena.

Jakobs assume o funcionalismo sistêmico luhmanniano de forma clara e explícita: a pena é uma forma de estabilização do sistema social. Através do processo de imputação e imposição de uma pena, o subsistema do direito confirma o ordenamento como aquele que deve ser seguido. A necessidade desta estabilização do ordenamento se verifica sempre que o sistema não consiga, através de medidas apropriadas, reduzir a uma medida irrelevante a possibilidade de ocorrência de comportamentos ilícitos, cujo efeito violador não possa ser compensado por meio de uma reorientação de comportamento, ao menos para o futuro ${ }^{206}$.

Com a imputação do comportamento defeituoso e a consequente imposição da pena, afirma-se a responsabilidade do autor e, ao mesmo tempo, se confirma que é correto confiar na norma. Nas palavras do professor de Bonn, "não se trata de uma intimidação geral, ou de intimidar, ao menos, aos potenciais delinquentes, senão da confirmação de que é correto confiar na correção da norma.”207

Como aponta Feijoo Sánchez, as primeiras aproximações de Jakobs à teoria da pena foram marcadas pela consideração da punição como mecanismo simbólico de influência psicológica nos membros da sociedade ${ }^{208}$ e deixam transparecer a influência do pensamento de Hans Welzel sobre a doutrina de um de seus mais destacados discípulos.

\footnotetext{
${ }^{205}$ JAKOBS, Günther . Culpabilidad y prevención, cit, p. 791

206 ibidem, pp. 81-82.

${ }^{207}$ ibidem, p. 98.

${ }^{208}$ FEIJOO SÁNCHEZ, Bernardo. Retribución y prevención general. Un estudio sobre la teoría de la pena y las funciones del Derecho Penal. Buenos Aires: B de F, 2007, p. 467.
} 


\subsection{2 - Sociedade, norma e pessoa em uma teoria de um direito penal funcional: a segunda fase do pensamento de Günther Jakobs}

Na década de 1990, Jakobs dedica-se a construir efetivamente uma teoria da pena anteriormente apenas esboçada. O núcleo de seu pensamento nesse período encontra-se em Sociedade, norma e pessoa em uma teoria de um direito penal funcional ${ }^{209}$. Neste trabalho, o autor potencializa a adoção do funcionalismo e desenvolve de maneira mais clara a relação entre o direito penal e a suas bases sociológicas e filosóficas. Nesse momento, o seu esboço teórico original ${ }^{210}$ já tinha sido objeto de duras críticas, as quais também foram enfrentadas pelo autor na obra ora mencionada.

A influência da sociologia de Niklas Luhmann perpassa toda a obra, embora o autor ressalte expressamente que sua construção teórica não seja uma adoção direta do sociólogo alemão ${ }^{211}$. Jakobs compreende a sociedade como um sistema social mantido pelas funções desenvolvidas por seus componentes. O sistema jurídico é caracterizado como um sistema autônomo e autossuficiente que exerce uma função absolutamente fundamental para a manutenção do sistema social, porque a constituição da sociedade tem lugar através de normas ${ }^{212}$.

A identidade da sociedade é determinada pelas regras que a configuram, ou seja, por meio de normas. Sob o enfoque funcionalista, o contexto de comunicação deve ser capaz de manter a sua configuração normativa frente a outros modelos divergentes, a fim de evitar que toda divergência seja o começo de um processo de transformação. Por tal motivo, de acordo com Jakobs, sociedade é compreendida como a construção de um contexto de comunicação, que se constitui por meio de um processo de configuração, e não pelo mero reconhecimento de um estado das coisas.

A constituição da sociedade tem lugar por meio de normas que precisam de estabilização, que, para o autor, se apresentam sob duas formas. O primeiro conjunto de normas encontra-se assegurada pela via cognitiva, são aquelas que vêm dadas pelo mundo

\footnotetext{
${ }^{209}$ JAKOBS, Günther. Sociedad, norma y persona en una teoría de un derecho penal funcional, cit., passim.

${ }^{210}$ Como o próprio autor se refere aos estudos sobre a pena até então. Cf. ibidem, p. 12.

${ }^{211}$ Cf. ibidem, p. 16.

${ }^{212}$ ibidem, p. 25.
} 
racional, de comum entendimento, produzidas na era moderna da comunicação e que não precisam de processos especiais de estabilização. Já a outra categoria de normas que configuram a sociedade não tem o condão de realizar sua própria estabilização. Ao contrário das primeiras, estas não são dadas prévia e naturalmente, mas são construídas para moldar a configuração da sociedade a uma determinada forma.

Além dos conceitos de sociedade e norma, bem como da relação entres ambos, Jakobs esclarece o papel da pessoa em sua perspectiva funcional, diante das severas críticas que recebera a partir de seus escritos precedentes, principalmente a de que o funcionalismo busca a estabilização da sociedade sem aludir ao sujeito livre, que seria absolutamente desconsiderado em sua teoria.

Para o autor, o sujeito não se encontra ausente na configuração social funcional, mas sua participação está inserida no processo de comunicação. Se a perspectiva funcional, de fato, está preocupada com a manutenção do sistema social, isso não significa que o sujeito não tem importância. Na medida em que se converte no objeto central da comunicação, o sujeito será um elemento dominante, e, somente nesse processo de comunicação, pode ser gerado o sujeito livre ${ }^{213}$.

Todavia, a despeito de toda a construção no sentido de relacionar a interdependência da subjetividade com a sociabilidade e de defender que o direito penal funcional não é por definição hostil ao sujeito, Jakobs admite que "quando Luhmann afirma que não existe 'exclusão de pessoas da sociedade', isso é correto, mas não implica que todos os seres humanos sejam pessoas."214

Jakobs promove a normatização do conceito de pessoa, que se configura como uma construção social da perspectiva comunicativa, de modo a possibilitar o abandono da ideia do indivíduo como titular de direitos fundamentais e permitir que determinados seres humanos não sejam considerados como pessoas para fins jurídico-penais. Além da influência de Luhmann na construção do conceito de pessoa a partir do processo comunicativo, o normativismo de Hans Kelsen se afigura como uma autêntica base teórica para Jakobs. Com efeito, na teoria pura do direito de Kelsen o conceito de pessoa é artificialmente definido pela ciência jurídica e não corresponde com o indivíduo existente

\footnotetext{
213 "Certamente, se o sujeito livre de fato não aparece na comunicação, efetivamente, carecerá de toda importância; mas também pode acontecer que se converta no objeto central da comunicação, e então será o elemento dominante, acima dos demais." JAKOBS, Günther. Sociedad, norma y persona en una teoría de un derecho penal funcional, cit., p. 29-30, tradução livre.

${ }^{214}$ ibidem, p. 38, nota de rodapé 27.
} 
no mundo, mas com um complexo de direito e deveres, de modo que, para o jurista austríaco, toda pessoa é, antes de tudo, uma pessoa jurídica ${ }^{215}$.

À influência do funcionalismo sistêmico na edificação dos conceitos de sociedade, norma e pessoa, Jakobs adere a dialética hegeliana ${ }^{216}$ para a configuração de sua teoria da pena e defende a compatibilidade entre as duas fontes teóricas, fazendo nascer aquilo que Bernardo Feijoo Sánchez denominou de "Hegel funcionalizado", "neo-hegelianismo funcional" ou "leitura luhmanniana de Hegel"217.

Para Jakobs, se tomada isoladamente, a pena não passa de um mal, e se olhada com relação ao fato punível, seria apenas a irracional sequência de dois males, segundo a formulação original de Hegel. A dialética hegeliana, contudo, engendraria uma relação de racionalidade se compreendida no contexto da complexa relação comunicativa da sociedade contemporânea. Assim, o delito deve ser entendido como afirmação que contradiz a norma e a pena como a resposta que confirma a norma ${ }^{218}$.

Como na concepção funcionalista de Jakobs a norma exerce o papel de constituição da própria sociedade, ao contradizer a contradição às normas determinantes da identidade da sociedade, a pena não realiza outra função senão a de confirmar a identidade do conjunto social. Por sua vez, o delito é compreendido nesse contexto como uma comunicação defeituosa, sendo a culpa imputada ao referido autor.

O direito penal restabelece no plano comunicativo a vigência perturbada da norma cada vez que procede à imputação e aplicação da pena como consequência da sua violação, e com isso mantém inalterada a identidade da sociedade. Para além de um meio utilizado para manter a identidade social, a pena constitui essa própria manutenção, uma verdadeira autocomprovação da referida identidade ${ }^{219}$.

Quanto ao destinatário da punição, esclarece o autor que a pena se impõe a sujeitos refratários, mas não irracionais, cujo projeto de mundo é contraditado pela sanção penal: o infrator "afirma a não vigência da norma para o caso em questão, mas a sanção afirma que

\footnotetext{
${ }^{215}$ KELSEN, Hans. Teoria pura do direito. Trad. João Baptista Machado. 6. ed. São Paulo: Martins Fontes, 1998, p. 194.

${ }^{216}$ JAKOBS, Günther. Sociedad, norma y persona en una teoría de un derecho penal funcional, cit., $p$. 39.

${ }^{217}$ FEIJOO SÁNCHEZ, Bernardo. Retribución y prevención general, cit., p. $473-475$.

218 "Somente sobre a base de uma compreensão comunicativa do delito entendido como afirmação que contradiz a norma e da pena entendida como resposta que confirma a norma pode estabelecer uma relação ineludível entra ambas." JAKOBS, Günther, op. cit., p. 16-17, tradução livre.

${ }^{219}$ Ibidem, p. 18.
} 
essa afirmação é irrelevante", de modo que a pena comunica e mantém, assim, a identidade da sociedade.

Ao contrário do que trouxera nos escritos iniciais, Jakobs abandona qualquer efeito psicológico que a pena possa acarretar, como o exercício de fidelidade ao direito ${ }^{220}$. Com essa modificação trazida pela influência hegeliana, Jakobs reelabora sua teoria da pena funcional como uma teoria retributiva, deixando o exercício de fidelidade ao direito apenas com um valor histórico dentro do desenvolvimento de sua concepção funcional de teoria da prevenção geral positiva ${ }^{221}$.

Por outro lado, o professor de Bonn aprofunda claramente sua concepção funcionalista do direito penal e da sociedade, que estabelece uma relação de estreita dependência, chegando a afirmar metaforicamente que o direito penal constitui um cartão de apresentação da sociedade altamente expressivo ${ }^{222}$. O direito penal se não vai representar o veículo propulsor de uma revolução social, também não pode ficar relegado a segundo plano, pois assume um papel fundamental de enfrentar problemas sociais e manter o funcionamento do sistema como um todo.

A perspectiva funcional se apresenta, portanto, como uma força de autoconservação do sistema social e, nessa medida, o direito penal assume um papel inegavelmente amplo, no qual, por exemplo, uma larga retirada para medidas jurídico-civis representaria uma crise do poder punitivo do Estado ${ }^{223}$.

A principal objeção que recebera até então e que procura responder na aludida obra é aquela realizada por autores como Winfried Hassemer no sentido de que também há proteção de normas em um direito penal aterrorizador, que atua em desrespeito aos direitos de liberdade e à própria pessoa, um direito penal que "serviria a qualquer senhor".

Jakobs aponta, em resposta, que se determinada sociedade está imersa em uma tendência para diminuição das liberdades, esta tendência não é fruto exclusivo do direito

\footnotetext{
220 "Certamente, pode ser que vinculem à pena determinadas esperanças de que se produzam consequências de psicologia social ou individual de muitas variadas características, como, por exemplo, a esperança de que se mantenha ou solidifique a fidelidade ao ordenamento jurídico. Mas a pena já significa algo com independência dessas consequências: significa uma autocomprovação.” JAKOBS, Günther. Sociedad, norma y persona en una teoría de un derecho penal funcional, cit, p. 18, tradução livre.

${ }^{221}$ FEIJOO SÁNCHEZ, Bernardo. Retribución y prevención general, cit., p. 469 e ss.

222 JAKOBS, Günther, op. cit., p. 22.

223 "Nenhum sistema pode renunciar a essa força: uma "crise do ius puniendi público", que, por exemplo, conduza a uma ampla retirada para medidas jurídico-civis, seria uma crise não só do ius puniendi, senão também do público.” ibidem, p. 37, tradução livre.
} 
penal, mas de toda a configuração social. A decisão sobre o incremento ou redução no processo de criminalização primária é, para ele, um problema puramente político, mas não jurídico-penal. O direito penal pode exercer um juízo valorativo positivo ou negativo sobre esse processo, mas é impotente frente às mudanças políticas de valores e não poderia optar em favor das referidas mudanças ${ }^{224}$.

\subsection{3 - A pena estatal: a consolidação da teoria da pena de Günther Jakobs}

Diante dos intensos debates e críticas à sua teoria da pena, que ganhara destacada importância, Günther Jakobs retoma o tema na década seguinte com grande clareza e profundidade, principalmente na obra $A$ pena estatal: significado e finalidade ${ }^{225}$. Seu conceito funcional de retribuição defendido no trabalho anterior não era capaz de responder a uma série de questões fundamentais, tais como critérios para a determinação da pena e a necessidade de vinculação da pena à dor e ao sofrimento humano. Reconheceu o autor, ainda, que sua teoria era destacadamente formal e abstrata, dissociada, portanto, da realidade social, conforme as críticas que recebera, de modo que o trabalho ora mencionado também tenta superar essa questão.

Nesse último período de desenvolvimento da sua teoria da pena, Jakobs retoma elementos de psicologia social para compatibilizar a ideia de retribuição ao aspecto preventivo da pena. Assim, à contradição da vigência da norma como retribuição que sempre caracteriza a pena, soma uma dimensão preventiva compatível com essa concepção: prevenir a erosão geral da vigência da norma ${ }^{226}$. Além disso, para consolidar a teoria da prevenção geral positiva, o autor realiza uma revisão teórica sobre os principais filósofos que se dedicaram à temática, inclusive tecendo profundas críticas a autores iluministas, passando por Kant e Feuerbach até chegar em Hegel, cujo apoio consolida sua própria teoria da pena como prevenção geral positiva.

\footnotetext{
${ }^{224}$ JAKOBS, Günther. Sociedad, norma y persona en una teoría de un derecho penal funcional, cit,, $p$. 41-42.

${ }^{225}$ JAKOBS, Günther. La pena estatal, cit., passim.

${ }^{226}$ FEIJOO SÁNCHEZ, Bernardo. Retribución y prevención general, cit., p. 491.
} 
Jakobs considera a filosofia hegeliana como aquela que teria dado o verdadeiro destaque para o caráter social do delito, o qual exerce papel determinante na teoria da pena. Para o filósofo alemão, o delito não se dirige ao outro no povo, mas atinge a estrutura social e o direito mesmo. O delito é uma coação exercida como violência pelo sujeito livre que lesiona a liberdade em sentido concreto. Ao imiscuir-se em propriedade alheia, por exemplo, o autor lesiona o respeito à esfera de liberdade de outrem e emite um juízo de que não reconhece a propriedade como de outra pessoa. Porém, como a legitimidade do direito de propriedade não está à disposição do autor, Hegel qualifica o delito como "nulo em si mesmo", uma comunicação que não permite invalidar a comunicação social de modo permanente, vez que se trata de uma realidade exclusivamente individual e sem futuro.

A pena, por sua vez, estabelece uma relação comunicativa com o autor do delito, que, em virtude do seu ato, será privado de direitos, notadamente a liberdade, a fim de que seja suspenso de alguma maneira como emissor e destinatário da comunicação ${ }^{227}$.

O delito e a pena, portanto, são compreendidos em um plano comunicativo: o delito como afirmação de que o direito não é vinculante e a pena como contradição, a afirmar que somente o direito pode constituir o ponto de partida da comunicação entre as pessoas. A contradição representada pela pena serve, pois, para confirmar que a estrutura da sociedade se mantém assegurada, que a norma se mantém vigente, mas não para garantir que não ocorram mais delitos.

Hegel não vê, como os iluministas, a dor da pena como um meio para provocar determinadas reações psíquicas de redução da motivação delitiva. Para ele, a dor característica da pena é um elemento simbólico que torna irrelevante a conduta delituosa e relevante o ordenamento jurídico ${ }^{228}$. É uma forma de manter a vigência da norma e garantir que somente o direito possa constituir o ponto de partida da comunicação na sociedade.

O significado de vigência da norma não se confunde com a garantia de segurança absoluta, ou seja, aquilo que o Estado promete manter não é a segurança máxima dos $\operatorname{cidadãos}^{229}$, senão um estado de juridicidade, de vigência do direito. Para Jakobs, o direito está em vigência sempre que constituir o esquema de orientação dominante para a prevenção do injusto ou para a reação frente ao seu acontecimento. A pena, portanto,

\footnotetext{
${ }^{227}$ JAKOBS, Günther. La pena estatal, cit., p. 133.

228 ibidem, p. 134.

${ }^{229}$ Defende o penalista alemão que o Estado não pode ao mesmo tempo perseguir a liberdade e impedir todo o abuso da liberdade, sob pena de se transformar em um Estado de vigilância totalitário. Cf. ibidem, p. 137.
} 
significa a contradição da negação da vigência da norma por parte do autor. Como a pena não é apenas essa contradição, senão que significa concretamente a imposição de dor a seu destinatário, Jakobs traz à lume um debate pouco enfrentado pelos penalistas: por que se elege a dor e não outra coisa como símbolo da pena?

A reação que contraria a negação da vigência da norma identifica o autor como fonte da violação, mas apenas isso não basta para a pena cumprir seu papel. Para a salvaguarda cognitiva da vigência da norma, o autor deve ser realmente tratado como tal, devendo ser eliminado da comunicação na sociedade de modo mais ou menos completo e por um tempo mais ou menos significativo ${ }^{230}$. Para o autor, somente a imposição da dor é capaz de resguardar cognitivamente a vigência da norma, pois ela demonstra o fracasso da conduta delitiva com vistas ao comportamento fiel ao direito dos cidadãos no futuro ${ }^{231}$. Se o delito é uma forma de infidelidade ao Direito, para que sua prática não se converta em um problema geral, é necessário que a pena represente dor e sofrimento ${ }^{232}$.

A despeito de ser aplicada ao autor do fato criminoso, a pena tem como destinatário a massa de cidadãos fiéis ao direito, para que conservem a fidelidade e confiança na norma. A pena é imposta ao autor do crime e destinada aos cidadãos fiéis ao direito, a fim de que as potenciais vítimas possam ter certeza de que têm direitos e podem exercê-los de maneira incólume.

A partir dessa construção teórica, Jakobs objetiva a manutenção da norma como esquema orientação social. Trata-se de uma teoria com fim preventivo e destinado ao conjunto dos cidadãos fiéis ao direito, uma prevenção geral positiva. Como seu objetivo não se relaciona com a motivação ou tendência criminosa, a medida do castigo se relacionará com a perturbação social gerada pelo ato ${ }^{233}$. Para determinar o grau da referida perturbação, o autor utiliza como critérios o peso da norma violada e a medida de sua

\footnotetext{
${ }^{230}$ JAKOBS, Günther. La pena estatal, cit., p. 143.

231 "Se ao autor se lhe impõe uma dor penal de tal intensidade que por causa da dor seu fato é considerado de forma geral um fracasso, com isso fica claro que no futuro o apoio cognitivo da norma ao menos não será pior do que antes do fato; esta manutenção do lado cognitivo da vigência da norma é o fim da pena", e em função de tal fim há de se determinar a pena.” ibidem, p. 142, tradução livre.

${ }^{232}$ FEIJOO SÁNCHEZ, Bernardo. Retribución y prevención general, cit., p. 494. Adverte em seguida o autor que "Se é assim, em sociedades onde a tendência dominante seja a infidelidade, parece que o recurso à dor e ao sofrimento deve ser maior.” Ibidem, p. 495, tradução livre.

${ }^{233} \mathrm{O}$ que dará ao papel dos meios de comunicação de massa um papel central no incremento do poder punitivo, conforme se apontará no capítulo 5 .
} 
violação, a situação de asseguramento cognitivo da norma e a responsabilidade do autor por sua motivação para cometer o delito ${ }^{234}$.

Reconhece o autor, todavia, que o efeito de produzir fidelidade ao direito acaba por também intimidar potenciais autores de delitos, pois "se a pena mantém a confiança na norma, deve produzir medo ou conviç̧ão, e só nesse caso manterá a confiança na norma" ${ }^{, 235}$. Assim, Jakobs admite que a pena também possui como efeito a prevenção geral negativa, ainda que contida e limitada pela prevenção geral positiva. A prevenção geral negativa não é propriamente uma função da pena, mas uma decorrência lógica e necessária da prevenção geral positiva, contida e limitada em seus efeitos para a manutenção da fidelidade ao direito.

\section{3 - O nascimento do direito penal do inimigo}

Com base nos conceitos que avoca da sociologia funcionalista e de ideias anteriormente desenvolvidas tanto no campo da criminologia positivista, quanto no direito penal e na filosofia política sobre a ideia de inimigo social ${ }^{236}$, Jakobs elabora um novo conceito de pessoa, inaugurando uma das construções teóricas mais controversas do direito penal contemporâneo: o direito penal do inimigo.

Para que um sujeito se constitua como pessoa é necessário que tenha o apoio cognitivo necessário para se orientar como destinatário da comunicação social da qual o direito faz parte. Para Jakobs, há pessoas que, com seu comportamento, não prestam a garantia cognitiva mínima necessária para serem tratadas como pessoas ${ }^{237}$. Quando um sujeito demonstra com suas condutas que no futuro não se poderá confiar que cumprirá as normas, ou seja, que não se pode confiar na expectativa comportamental desse sujeito, ele

\footnotetext{
${ }^{234}$ JAKOBS, Günther. La pena estatal, cit., p. 146.

235 ibidem, p. 148.

${ }^{236}$ Sobre os antecedentes teóricos do direito penal do inimigo, cf. BECHARA, Ana Elisa Liberatores Silva. Bem jurídico-penal, cit., p. 301 e ss; ZAFFARONI, Eugenio Raúl. O inimigo no direito penal. Trad. Sérgio Lamarão. 2 ed. Rio de Janeiro: Revan, 2007, p. 29 e ss.

237 "Quem não presta a garantia cognitiva de que se comportará como pessoa no Direito, tampouco deve ser tratada como pessoa no Direito.” JAKOBS, Günther, op. cit., p. 174.
} 
deixa de ser tratado como pessoa e passa a ser considerado um indivíduo perigoso, juridicamente despersonalizado ${ }^{238}$.

A referida despersonalização não se confunde com a perda da personalidade jurídica, mas se trata de uma desconsideração da condição de pessoa para fins penais "exclusivamente no que se refere ao possível uso defeituoso da liberdade"239. Defende o autor se tratar de um asseguramento de relações jurídicas, não da destruição arbitrária do outro. Todavia, admite um incremento da despersonalização na medida em que aumenta a periculosidade do sujeito.

Estabelece-se, assim, uma divisão entre o direito penal do cidadão e o direito penal do inimigo, criando aquilo que Juarez Cirino dos Santos chamou de discurso desigual do direito penal ${ }^{240}$. No primeiro caso fica garantida a aplicação do direito penal tradicional, com todas as garantias historicamente reconhecidas, enquanto no direito penal do inimigo resta estabelecida uma relação de guerra contra o sujeito perigoso. Trata-se, com efeito, de "dois polos de um só mundo ou de mostrar duas tendências opostas em um só contexto jurídico-penal" ${ }^{241}$, sendo possível a superposição entre ambos dada a fluidez dos fenômenos.

Essa guerra que se estabelece contra o inimigo constitui, para o autor, um legítimo direito dos cidadãos ${ }^{242}$. $\mathrm{O}$ direito à segurança do cidadão confere a ele o direito de excluir todo aquele que não ofereça garantia de um comportamento pessoal conforme a pauta normativa vigente na sociedade.

A prevenção geral positiva segue dirigida ao cidadão: a conduta de uma pessoa racional significa uma desautorização da norma e sua vigência, enquanto a pena significa que a afirmação do autor é irrelevante e que a norma segue em vigência e a configuração da sociedade mantida. Para Jakobs, só faz sentido contradizer a conduta do autor se este for considerado uma pessoa, se for capaz de compreender o sentido da comunicação levada a efeito pela pena. Ao indivíduo perigoso, por outro lado, não interessa qualquer comunicação, pois ele está fora do direito. A pena representa somente coação na luta

\footnotetext{
${ }^{238}$ JAKOBS, Günther. La pena estatal, cit., p. 172.

239 ibidem, p. 173.

${ }^{240}$ SANTOS, Juarez Cirino dos. Direito penal do inimigo - ou o discurso do direito penal desigual. Disponível em http://icpc.org.br/artigos/ Acesso em 25/11/2014.

${ }^{241}$ JAKOBS, Günther; CANCIO MELIÁ, Manuel. Derecho penal del enemigo. Trad. Manuel Cancio Meliá. Madrid: Civitas, 2003, p. 22.

${ }^{242}$ ibidem, p. 56.
} 
contra o perigo representado pelo inimigo. Sua função é unicamente a inocuização, devendo ser fisicamente efetiva para assegurar a sociedade dos riscos que são ínsitos ao indivíduo perigoso ${ }^{243}$.

Cumpre destacar que Jakobs não só resgata a teoria da prevenção especial negativa para o controle dos inimigos perigosos, senão que faz uma advertência ao reconhecer que, caso não fossem os efeitos de encerramento que fisicamente produz ao apartar o indivíduo do convívio social, seria improvável que a pena privativa de liberdade tivesse se transformado na reação habitual contra fatos de certa gravidade ${ }^{244}$.

Conforme aponta Feijoo Sánchez, Jakobs retoma as piores versões da prevenção especial, traz de volta à cena os "incorrigíveis" de Franz von Liszt ${ }^{245}$ e utiliza elementos fáticos que rompem com sua pretendida fundamentação normativa da teoria da pena. A retomada da prevenção especial negativa rompe até certo ponto o sistema proposto pelo autor até então $^{246}$.

Por ser um único contexto jurídico em que estão presentes as duas formas de direito penal acima descritas, a teoria da pena de Jakobs ganha novos elementos e uma complexidade ainda maior.

\section{4 - A prevenção geral positiva limitadora de Winfried Hassemer e Claus Roxin}

Ao lado da teoria da prevenção geral positiva desenvolvida por Jakobs, foram fundadas outras propostas semelhantes, mas com fundamentos e objetivos políticocriminais diferentes $^{247}$, que merecem destaque. São as chamadas teorias da prevenção geral

\footnotetext{
243 "No Direito penal do cidadão, a função manifesta da pena é a contradição, no Direito penal do inimigo a eliminação de um perigo. Os correspondentes tipos ideais praticamente nunca aparecerão em uma configuração pura. Ambos tipos podem ser legítimos." JAKOBS, Günther; CANCIO MELIÁ, Manuel. Derecho penal del enemigo, cit., p. 55, tradução livre.

${ }^{244}$ Ibidem, p. 23-24.

${ }^{245}$ Cf. LISZT, Franz von. La idea del fin en el Derecho Penal, cit., p. 83 e ss.

${ }^{246}$ FEIJOO SÁNCHEZ, Bernardo. Retribución y prevención general , cit., p. 498-499.

${ }^{247}$ BOZZA, Fábio da Silva. Teorias da pena, cit., p. 73; SANTOS, Juarez Cirino dos. Teoria da pena, cit., p. 30-31.
} 
positiva limitadoras, que, conforme a classificação difundida por Mir Puig, se contrapõem à prevenção geral positiva fundamentadora ${ }^{248}$. Seus principais representantes são os professores alemães Winfried Hassemer e Claus Roxin.

Winfried Hassemer analisa as finalidades da pena (e o direito penal como um todo) dentro do sistema de controle social necessário para a manutenção da vida em sociedade $^{249}$. Para o autor, o sistema de controle social, formado por norma, sanção e o processo de controle, é o responsável por assegurar as normas e as expectativas de conduta, sem as quais a sociedade não poderia existir. O professor de Frankfurt defende que as normas estabelecidas pelo controle social conferem à sociedade a sua face e sua autocompreensão. $^{250}$

Como parte do sistema de controle social, o direito penal igualmente assegura as normas e as expectativas de conduta, determina os limites da conduta humana e é um meio de desenvolvimento cultural e socialização. Todavia, diferencia-se dos demais mecanismos de controle social pelas características de seus objetos, os conflitos desviantes de maior relevância social, e de seus instrumentos, que são os meios mais rigorosos de intervenção, suas sanções e seus meios de coação formalizados, ou seja, promove "a transformação dos conflitos mais graves com os meios mais rigorosos" ${ }^{251}$. O sistema de controle social do qual o direito penal faz parte deve ser harmônico e integrado, respeitando os limites que cada uma das esferas de controle deve exercer.

Hassemer também desenvolve sua teoria da prevenção geral positiva a partir da constatação da falência das demais teorias até então dominantes. Para ele, a prevenção especial e a prevenção geral por intimidação dependem insistentemente de verificação empírica, mas a realidade demonstrou sua parca eficácia e, consequentemente, a falta de justificação social. Todavia, ao desenvolver a teoria da prevenção geral positiva para assegurar as normas e expectativas sociais, não comunga dos mesmos pressupostos e objetivos político-criminais de Jakobs.

\footnotetext{
${ }^{248}$ MIR PUIG, Santiago. Función fundamentadora y función limitadora de la prevención general positiva. Anuário de Derecho Penal y Ciencias Penales, t. 39, fasc. II, Madrid, p. 49 e ss.

${ }^{249}$ HASSEMER, Winfried. Introdução aos fundamentos do Direito Penal. Trad. de Pablo Rodrigo Alflen da Silva. Porto Alegre: Sergio Antonio Fabris Editor, 2005, p. 414.

${ }^{250}$ HASSEMER, Winfried, op. cit., p. 414-415.

${ }^{251}$ HASSEMER, Winfried, op. cit., p. 415-416. Conforme aponta o autor, "norma penal, sanção penal e processo penal estão relacionados com as normas, sanções e processos dos demais âmbitos de controle social, eles "formam" o sistema completo de transformação social do desvio."
} 
Para Hassemer, os fins da pena podem e devem ser alcançados sem olvidar sua tarefa de proteção dos bens jurídico-penais e devem estar sempre vinculados aos princípios de valor construídos pelo pensamento liberal iluminista, os chamados princípios penais clássicos, tais como o da culpabilidade, legalidade e os demais que formam o arcabouço de garantias do indivíduos frente ao poder punitivo estatal. Ao contrário de Jakobs, não autoriza um tratamento diferenciado por parte do Estado em relação às pessoas, não separa os indivíduos entre bons e maus, tampouco admite qualquer diferenciação com base em conceitos positivistas de inclinação ao crime.

O ponto central que caracteriza a prevenção geral positiva no pensamento de Hassemer é que a tarefa de assegurar as normas e expectativas comportamentais deve ser acompanhada de limites que assegurem a autonomia do sujeito ${ }^{252}$. Para tanto, por exemplo, não deve ser levado em conta apenas o aspecto da criminalização, senão também o da descriminalização de condutas, para que os fins da pena sejam transmitidos não pelo medo, mas pelo conhecimento e aceitação das normas e a pena possa se tornar um exemplo normativamente justificado de relação humana com o desvio ${ }^{253}$.

A teoria da pena de Hassemer tenta colocar os interesses preventivos em uma relação normativa, justificando e, ao mesmo tempo, limitando os referidos interesses ${ }^{254}$. Todavia o autor não abandona aspectos retributivos e de prevenção intimidatória e "ressocializadora" que a pena pode realizar, além de admitir problemas na construção ainda inacabada da prevenção geral positiva, que se sustenta com pressupostos mais debilitados, uma vez que sua natureza normativa não necessitaria como as demais de constante comprovação empírica no mundo concreto.

Por sua vez, Claus Roxin, que inaugurou o chamado funcionalismo penal, propõe o resgate valorativo político-criminal no sistema do direito penal como resposta ao positivismo herdado de Franz von Liszt que banira deste ramo do direito as dimensões

\footnotetext{
${ }^{252}$ HASSEMER, Winfried. Introdução aos fundamentos do Direito Penal, cit., p. 426.

253 “É certo que o Direito Penal e a pena, vistos a partir da ideia de controle social, têm a tarefa de afirmar e assegurar publicamente as normas fundamentais que estão dispostas no Direito Penal Material: de traçar os limites da liberdade que todo cidadão deve respeitar, com isto nós podemos existir em conjunto. Mas também é certo que o Direito Penal, limitado a esta tarefa, transmite-se unilateralmente à população. A prevenção geral positiva se estabelece somente quando ambos os lados da moeda do "controle jurídico-penal do crime" apresentam graves consequências para a formação social da norma. Neste caso o Direito Penal e a pena podem se tornar um exemplo normativamente fundamentado de relação humana com o desvio." Ibidem, p. 425.

${ }^{254}$ COSTA, Helena Regina Lobo da. A dignidade humana: teorias da prevenção geral positiva. São Paulo: Editora Revista dos Tribunais, 2008, p. 82.
} 
sociais e políticas e, consequentemente, a própria relação direta com a política criminal ${ }^{255}$. Roxin conecta todo o sistema de direito penal à política criminal e aos fins da pena, que, por isso mesmo, passa a receber uma importância que até então restava em segundo plano frente ao interesse predominante dos penalistas no estudo da teoria do delito.

$\mathrm{Na}$ teoria da pena de Roxin, a prevenção geral positiva ganha destaque como mecanismo de conservação e reforço da confiança na firmeza e poder de execução do ordenamento jurídico. Para o autor, a prevenção geral em seu aspecto de demonstrar a inviolabilidade do ordenamento jurídico ante a comunidade jurídica e reforçar a confiança jurídica do povo atualmente recebe um significado ainda maior do que a prevenção geral intimidatória ${ }^{256}$.

Roxin atribui três finalidades imbricadas da prevenção geral positiva: o efeito de aprendizagem, de motivação sociopedagógica para o exercício de confiança no direito por parte da população que deriva da atividade judicial; o efeito de reforço da confiança jurídica que surge quando o cidadão percebe que o direito penal é aplicado; e o efeito pacificador, produzido quando a consciência geral se tranquiliza em virtude da sanção aplicada àquele que viola o direito e, assim, considera que o conflito foi solucionado ${ }^{257}$.

A despeito da importância conferida à prevenção geral positiva ${ }^{258}$, na teoria da pena construída por Roxin ela exerce um papel complementar em relação às demais teorias preventivas. A partir das duras críticas que todas as teorias preventivas da pena recebem individualmente, o autor desenvolve a teoria unificadora preventiva dialética da pena, que, para além da simples justaposição, combina as diferentes características positivas das concepções preventivas da pena de modo a superar suas deficiências quando analisadas de forma isolada.

Desta maneira, mesmo apontando críticas a todas as teorias da pena até então desenvolvidas, Roxin elabora uma teoria da pena exclusivamente preventiva, combinando

\footnotetext{
${ }^{255}$ ROXIN, Claus. Política criminal e sistema jurídico-penal, cit., p. 12. "O positivismo como teoria jurídica caracteriza-se por banir da esfera do direito as dimensões do social e do político. Exatamente esse pensamento, por Liszt tomado como um óbvio axioma, fundamenta a oposição entre direito penal e política criminal: o direito penal só será ciência em sentido próprio, enquanto se ocupar da análise conceitual das regulamentações jurídico-positivas e de sua ordenação no sistema. A política criminal, que se importa com os conteúdos sociais e fins do direito penal, encontra-se fora do âmbito do jurídico."

${ }^{256}$ ROXIN, Claus. Derecho penal, cit., p. 91.

${ }^{257}$ ibidem, p. 91-92.; BOZZA, Fábio da Silva. Teorias da pena, cit., p. 73.

${ }^{258}$ Cf. ROXIN, Claus. Prevención y determinación de la pena. Trad. de Francisco Munñoz Conde. Doctrina Penal, Año 3, no 9-12, Buenos Aires: Depalma, 1980.
} 
aspectos de prevenção geral e especial como forma de "proteção da liberdade individual" em uma ordem social que está a seu serviço ${ }^{259}$. O aspecto preventivo da teoria unificadora preventiva dialética da pena não se destina a evitar a erosão da vigência da norma propriamente, senão que se destina a prevenção de delitos entendidos como lesões de bens jurídicos fundamentais.

\section{5 - Prevenção geral positiva em Günther Jakobs: síntese conclusiva}

No plano sociológico, parece manifesta a influência exercida pela sociologia funcionalista para a construção de sua teoria da prevenção geral positiva. A inovação e originalidade pretendida por Jakobs reside primordialmente na adoção do referencial funcionalista para explicação da sociedade na qual o direito penal está inserido. De maneira geral o autor assume alguns pressupostos próprios da sociologia funcionalista inaugurada por Durkheim e se assume nominalmente como um funcionalista.

De fato, Jakobs compreende a sociedade em harmonia e coesão, cujo valor da ordem assume um papel central e norteará o fim da pena. As ideias de coesão, ordem e integração constituem a preocupação central do modo como o autor compreende a sociedade. Nesse sentido, adota o referencial das teorias do consenso social, cujos valores dominantes e determinantes para a vida em sociedade são dados construídos de forma consensual e harmônica.

Como funcionalista, assume a diferenciação entre funções e papéis sociais entre instituições e indivíduos que compõem a sociedade, bem como analisa as consequências positivas dos fenômenos para o seu conjunto. A influência desse conjunto de ideias gerais do funcionalismo constitui a base por meio da qual construirá todo o seu arcabouço teórico do direito penal.

Com efeito, a principal referência funcionalista de Jakobs é aquela exercida por Niklas Luhmann e sua teoria dos sistemas. As concepções do direito como um sistema social fechado e autorreferencial e, principalmente, a noção de expectativas sociais que

${ }^{259}$ ROXIN, Claus. Derecho penal, cit, p. 95. 
devem ser estabilizadas para a manutenção da ordem representaram o substrato daquilo que Jakobs tentou empreender como inovação para superar diversos problemas identificados na ciência penal até então.

Contudo, é preciso consignar que Jakobs não empreende ou mesmo tenta empreender uma transposição da sociologia funcionalista sistêmica para o direito penal, ou seja, não adota de forma pura e direta o funcionalismo sistêmico para, a partir daí, construir sua teoria penal. A adesão ao funcionalismo sistêmico é relativa ${ }^{260}$ e muitas vezes até imprecisa conceitualmente ${ }^{261}$.

Com efeito, o pensamento funcionalista serviu de forte influência para o pensamento de Jakobs, especialmente para a forma como entende a sociedade e, consequentemente, as funções ou papéis que as instituições e os indivíduos devem exercer para a sua coesão. Se por um lado Jakobs é um autor funcionalista, por outro isso não significa que seja rigoroso na abordagem conceitual do referencial sociológico. A adoção das ideias e dos conceitos gerais do funcionalismo sistêmico é de certa forma genérica e relativa, sem um rigor preciso e uma transposição direta na construção de sua teoria do direito penal e da pena.

É possível afirmar, portanto, que Jakobs faz um uso possível dos conceitos e ideias funcionalistas para conformar seu pensamento acerca do direito penal. Assim, se não é possível afirmar que se trate propriamente de um legado fiel do funcionalismo sistêmico, pois em alguns momentos a utilização de conceitos pode ser classificada como vulgar e genérica, não deixa de ser um uso possibilitado por aquele referencial teórico. Se Jakobs não é um discípulo rigoroso do funcionalismo sistêmico, não deixa de ser um funcionalista.

\footnotetext{
${ }^{260}$ Sobre a reatividade da adoção do pensamento de Luhmann por Jakobs, cf. SAAD-DINIZ, Eduardo. Inimigo e pessoa no direito penal. São Paulo: LiberArs, 2012, p. 67 e ss; BECHARA, Ana Elisa Liberatore Silva. Bem jurídico-penal, cit., p. 290.

${ }^{261}$ Nesse sentido, Mariana Thorstensen Possas pondera que "Jakobs transfere para a literatura jurídico-penal algumas ideias e conceitos que ele observa nos trabalhos sociológicos de Niklas Luhmann. Apesar das frequentes referencias à literatura sociológica, o autor constrói a teoria da prevenção geral positiva a partir exclusivamente do direito penal e não, por exemplo, a partir do direito em seu conjunto. Importar algumas ideias da sociologia não significa fazer sociologia. É preciso ter isso em mente para relativizar a influência de Luhmann na obra de Jakobs, e resistir à tendência a interpretá-la como um legado da sociologia do direito luhmaniana. A questão, assim, é observar como foi produzida a transferência dessas ideias e conceitos, ou seja, qual é o (novo) sentido que Jakobs dá às ideias de Luhmann." POSSAS, Mariana Thorstensen. O problema da inovação da teoria da prevenção geral positiva. Revista Brasileira de Ciências Criminais, vol. 56, São Paulo: Editora Revista dos Tribunais, 2005, p. 287-288. Para uma análise da relatividade da adaptação da obra de Niklas Luhman por Günther Jakobs, mas apontando de maneira firme a grande influência exercida, cf. PORTILLA CONTRERAS, Guillermo. Los excesos del formalismo jurídico neofuncionalista en el normativismo del Derecho penal. In.: PORTILLA CONTRERAS, Guillermo (coord.). Mutaciones de Leviatán: legitimación de los nuevos modelos penales. Madrid: Akal, 2005, p. 63.
} 
A relativização da influência de Luhmann é reconhecida pelo próprio autor ${ }^{262}$, mas sua obra não deixa dúvidas de que referida matriz teórica é o que traz a pretensa originalidade do seu pensamento no âmbito do sistema penal.

Do ponto de vista filosófico, a teoria da prevenção geral positiva de Jakobs passou a ser influenciada ao longo do tempo pela dialética hegeliana, especialmente sua teoria da pena como retribuição desenvolvida na Filosofia do Direito de 1820/1821 ${ }^{263}$.

Para Hegel existe uma vontade geral na sociedade que está representada pelo direito abstrato, que é contraposta pela vontade particular de uma pessoa que, com seu comportamento, nega a vontade geral. A finalidade da pena é restabelecer a vontade geral por meio da negação do comportamento individual contrário à vontade geral, ou seja, a pena representa a negação da negação: o crime nega a vontade geral e a pena nega o comportamento delitivo.

Segundo o desenvolvimento da pena de Hegel, quem comete um delito acaba por expressar sua particular concepção de mundo, pois para o autor do fato criminoso o que está em vigência não é o ordenamento jurídico, senão a sua vontade particular, que efetivamente nega aquele ordenamento. Por meio da pena, o Estado nega a negação do autor ao manifestar que sua especial concepção de mundo não é válida e que deve imperar a vontade geral de modo a restabelecer a vigência do direito (síntese) ${ }^{264}$.

O penalista alemão, por sua vez, redefinirá a pena de maneira a não admitir apenas a retribuição de um mal por outro mal que, seria a pena. Para ele, a pena deve ser definida de forma positiva na medida em que deve gerar a estabilização da norma lesionada como consequência positiva da aplicação do mal que, de fato, representa a pena ${ }^{265}$.

Jakobs utilizará a lógica dialética empreendida por Hegel e a cotejará com sua concepção funcionalista de sociedade, a fim de elaborar a teoria da prevenção geral positiva. Seguindo a influência de Luhmann, Jakobs defende que o direito é uma estrutura que permite a orientação social, sendo a norma uma generalização de expectativas comportamentais. As normas formam a própria identidade da sociedade e são

\footnotetext{
${ }^{262}$ JAKOBS, Günther. Sociedad, norma y persona en una teoría de un derecho penal funcional, cit., p. 16.

${ }^{263}$ HEGEL, Georg Whilhelm Friedrich. Filosofia do direito, cit..

${ }^{264}$ MONTEALEGRE LYNETT, Eduardo. Estudio introductorio a la obra de Günther Jakobs. In. MONTEALEGRE LYNETT, Eduardo (coord.). El funcionalismo en Derecho Penal: libro homenaje al Professor Günther Jakobs. Bogotá: Universidad Externado de Colombia, 2003, p. 24.

${ }^{265}$ Cf. JAKOBS, Günther. Derecho penal, cit., p. 9.
} 
compreendidas como expectativas de comportamento estabilizadas em termos contrafáticos. Desta forma, a frustração de uma expectativa comportamental através do comportamento criminoso (negação) deve ser rechaçada pela aplicação da pena (negação da negação) como maneira de estabilizar as expectativas sociais e garantir a vigência da norma e, consequentemente, a configuração fundamental da sociedade (síntese) $)^{266}$.

A utilização de Hegel na construção da teoria de Jakobs, todavia, é limitada basicamente ao que desenvolvera em sua teoria retributiva da pena. De fato, não há significativas apropriações do conjunto filosófico desenvolvido por Hegel para além da lógica dialética empreendida na elaboração da teoria dos fins da pena, de maneira que o sistema de direito penal desenvolvido por Jakobs não avança nessa influência de maneira significativa para a totalidade do conjunto filosófico hegeliano em suas nuances e complexidades.

Diante da consideração da sociedade em um plano harmônico e integrado, a concepção de direito do autor não poderia ser muito distinta daquela que defende seu papel para a manutenção da referida harmonia. No entanto, Jakobs vai além e introduz uma relação particularmente estreita entre direito e sociedade.

O penalista de Bonn compreende o direito como um subsistema social autônomo e autossuficiente, cuja função primordial é a manutenção do sistema social harmônico. Seguindo a influência de Luhmann, defende que o direito regula padrões de comportamento ao criar expectativas de condutas por um lado, e assegurar a vigência delas de outro, com o objetivo de garantir uma previsibilidade nas complexas relações sociais ${ }^{267}$. $\mathrm{O}$ direito atua, portanto, em um processo comunicativo de estabilização de expectativas sociais e consequente redução da complexidade característica da sociedade contemporânea.

\footnotetext{
${ }^{266}$ Sobre a principal diferença entre as concepções de Jakobs e Hegel, afirmam Enrique Peñaranda Ramos, Carlos Suárez González e Manuel Cancio Meliá que "a principal diferença consistiria, propriamente, em que o ponto de referência na fundamentação hegeliana da pena é o conceito abstrato de direito, enquanto em Jakobs, esse ponto de referencia vem construído pelas condições de subsistência da sociedade, de uma determinada sociedade." In. PEÑARANDA RAMOS, Enrique; SUÁREZ GONZÁLEZ, Carlos; CANCIO MELIÁ, Manuel. Um Novo Sistema do Direito Penal. Considerações sobre a teoria da imputação objetiva de Günther Jakobs. Tradução de André Luís Callegari e Nereu José Giacomolli. 2. ed. Porto Alegre: Livraria do Advogado Editora, 2013, p. 25.

267 “Assim como os homens em sua relação com a natureza só se orientam na medida em que podem encontrar regularidades, do mesmo modo nos contatos sociais - os únicos que aqui interessam - só resulta possível a orientação se não há que contar a cada momento com qualquer comportamento imprevisível da outra pessoa. Do contrário cada contato social se converteria em um risco imprevisível.” JAKOBS, Günther. Derecho penal, cit., p.9.
} 
A particularidade atribuída à relação entre direito e sociedade reside na peculiar consideração de que a identidade da sociedade se configura por meio de normas, ou seja, as normas constituem o substrato que determina a identidade da sociedade e ao mesmo tempo são o seu próprio reflexo. As normas são produtos do consenso social vigente e revelam a identidade da sociedade, que deve ser preservada pelo processo de estabilização levada a efeito pelo ordenamento jurídico de maneira a evitar processos de transformação por modelos divergentes. Desta forma, o autor adota a curiosa compreensão segundo a qual a sociedade é constituída por normas que, por sua vez, são o reflexo da própria identidade da sociedade.

Por conseguinte, a aferição da legitimidade do direito é exercida em um plano interno ao sistema jurídico, ou seja, dentro do próprio direito, que é legitimado enquanto se mantém íntegro na tarefa de garantia da harmonia e da ordem social vigente em determinado período histórico, sem a necessidade de utilização de um referencial externo para a realização de tal tarefa, sendo válido notar que o aporte teórico engendrado pelo funcionalismo sistêmico se aproxima do normativismo desenvolvido por Hans Kelsen ${ }^{268}$.

No plano jurídico-penal, embora a teoria da prevenção geral positiva tenha semelhanças remotas com o pensamento desenvolvido por Francesco Carrara no âmbito da escola clássica italiana ${ }^{269}$, a grande influência de Jakobs foi realmente o conjunto teórico sobre os fins da pena desenvolvido pelo seu mestre Hans Welzel.

Com efeito, Welzel destacou de forma inovadora naquele momento histórico que os tradicionais fins atribuídos à pena deveriam ocupar um plano secundário, pois o principal objetivo da punição levada a cabo pelo direito penal deveria ser positivo, com a criação de uma tendência comportamental permanente para a defesa dos valores éticosociais, que para o autor são os valores que constituem a consciência jurídica e a base da vida social.

Os conceitos centrais do que se entende hoje por prevenção geral positiva ganharam relevo na doutrina penal de Welzel. As ideias essenciais utilizadas pelo funcionalismo penal contemporâneo, como a de assegurar a vigência da norma e estimular a fidelidade ao direito pelos cidadãos são primeiramente enfatizadas no finalismo de

\footnotetext{
${ }^{268}$ Nesse sentido, cf. BECHARA, Ana Elisa Liberatore Silva. Bem jurídico-penal, cit., p. 307.

${ }^{269}$ Para a teoria da pena como restabelecimento da ordem externa da sociedade, com semelhanças ao que contemporaneamente é defendido por Jakobs, cf. CARRARA, Francesco. Programa do curso de direito criminal: parte geral. Trad. José Luiz Franceschini e Prestes Barra. São Paulo: Saraiva, 1956, § 615 e ss.
} 
Welzel, cujo influxo certamente se faz sentir na moderna teoria da prevenção geral positiva.

Não obstante a referida influência, Jakobs inaugura um outro sistema de direito penal $^{270}$ sob as novas bases do funcionalismo sistêmico, e neste rumo, além de elaborar uma completa renormativização dos conceitos jurídico-penais, atribui relevância cada vez maior às ideias de manutenção da vigência da norma em detrimento da relação interna entre sujeito e norma, um dos pilares fundamentais do finalismo que abandona ${ }^{271}$.

A teoria da prevenção geral positiva construída sobre essas bases passou por um longo processo de elaboração, muito embora seus pilares fundamentais tenham permanecido pouco alterados durante sua constante elaboração. Com efeito, as ideias expostas já em Culpabilidade e Prevenção são permanentemente debatidas, esclarecidas e reelaboradas, mas ao contrário de qualquer tipo de negação ou abandono, são reforçadas em sua versão contemporaneamente difundida.

Para Jakobs, interessam ao direito penal aquelas normas cuja observância geral não pode ser abandonada sob risco de erosão da configuração fundamental da sociedade. A pena como reação contrafática ao questionamento da norma tem a missão de mantê-las como modelo de orientação para os contatos sociais ${ }^{272}$. A reação à negação de vigência da norma, todavia, não o torna um defensor declarado do retributivismo, sob o argumento de que a pena não pode renunciar ao seu aspecto positivo e preventivo.

A prevenção do delito por meio da pena deve garantir as condições para o convívio social harmônico e exercitar a confiança na norma, a fidelidade ao direito e a aceitação das consequências $^{273}$. A estabilização das expectativas normativas através do processo simbólico e comunicativo levado a efeito pela pena confirmaria a estrutura vigente na sociedade, cujo identidade é constituída pelas normas.

Trata-se inegavelmente de uma teoria fundamentadora do incremento do poder de punir do Estado, ao contrário das outras versões da prevenção geral positiva, que ao menos declaradamente seriam destinadas à limitação do referido poder, embora, sem dúvidas, o legitimem ao conferir um efeito positivo ao seu exercício. E como o autor tentou ao longo

\footnotetext{
${ }^{270}$ MONTEALEGRE LYNETT, Eduardo. Estudio introductorio a la obra de Günther Jakobs, cit., p. 23.

${ }^{271}$ Nesse sentido, cf. PEÑARANDA RAMOS, Enrique; SUÁREZ GONZÁLEZ, Carlos; CANCIO MELIÁ, Manuel. Um Novo Sistema do Direito Penal, p. 13 e 17.

${ }^{272}$ JAKOBS, Günther. Derecho penal, cit., p.14.

${ }^{273}$ ibidem, p. 18.
} 
de seu percurso teórico responder às críticas a ele dirigidas, nesse ponto deixou claro: o incremento da criminalização é um problema político, não jurídico-penal.

Outras críticas realizadas ao sistema de direito penal elaborado por Jakobs também foram fundamentais para que o próprio autor pudesse deixar ainda mais clara sua pretensão teórica. Exemplo disso são as questões relacionadas à prevenção geral positiva e segurança pública, bem como a necessidade de alcançar a estabilização normativa por meio da dor e do sofrimento humano.

No que se refere ao primeiro ponto, esclarece que a confirmação da estrutura da sociedade por meio da estabilização das expectativas normativas não significa uma garantia de segurança absoluta, de prevenção efetiva dos delitos futuros. Para ele basta que vigore um estado de juridicidade, de vigência do direito como esquema de orientação dominante às custas de alguns responsáveis.

Por outro lado, também defende de forma absolutamente clara que a pena deve representar dor e sofrimento do ser humano, tema raramente enfrentado pelos teóricos que legitimam a pena como forma de prevenção criminal. Para Jakobs, somente a imposição da dor é capaz de resguardar cognitivamente a vigência da norma, pois assim ficaria demonstrado o fracasso da conduta delitiva em contraposição ao comportamento fiel ao direito dos cidadãos no futuro.

A despeito de considerar a prevenção geral positiva como o único fim da pena, ao final acaba por admitir que dela decorrem efeitos secundários (ou nela estariam inseridas) outras finalidades como a própria prevenção geral negativa, por ele duramente criticada. Por outra via, ao elaborar a teoria do direito penal do inimigo, versões destacadamente autoritárias da prevenção especial também passam a fazer parte do seu conjunto teórico, ainda que sob o manto de outra espécie de direito penal, o que, todavia, não deixa de se configurar como evidente hipótese de manifestação do poder punitivo do Estado.

Se por um lado as críticas apontavam as incongruências da teoria em tela, por outro contribuíam para que Jakobs as refutasse, reforçando sua própria construção teórica. A teoria da prevenção geral positiva, por fim, foi caracterizada por um viés cada vez mais idealista, abstrato, pretensamente neutro e sistematicamente coerente, exemplo típico do 
que Max Horkheimer qualifica como teoria tradicional ${ }^{274}$ e cuja crítica será exposta nos capítulos que seguem.

${ }^{274}$ Cf. HORKHEIMER, Max. Teoría Tradicional y Teoría Crítica. In: HORKHEIMER, Max. Teoría Crítica. Buenos Aires. Amorrortu, 2003. 
Parte II - A DESCONSTRUÇÃO DA TEORIA DA PREVENÇÃO GERAL POSITIVA DE GÜNTHER JAKOBS 


\section{CAPÍTULO 4 - ANÁLISE CRÍTICA DOS PRESSUPOSTOS TEÓRICOS DA PREVENÇÃO GERAL POSITIVA}

SUMÁRIO: 4. Análise crítica dos pressupostos teóricos da prevenção geral positiva - 4.1. Crítica aos fundamentos sociológicos - 4.1.1. Funcionalismo e conservação da ordem 4.1.2. Crítica ao funcionalismo sistêmico de Niklas Luhmann - 4.2. Crítica das bases jurídico-filosóficas do pensamento de Günther Jakobs - 4.2.1. Direito e ausência de suporte material - 4.2.2. Conceito de pessoa e suas consequências - 4.3. Bases para uma análise crítica do direito - 4.4. Teoria crítica e o direito penal: a crítica criminológica do direito penal

A crítica proposta no presente trabalho demanda uma análise não só das consequências da prevenção geral positiva no âmbito do sistema penal, mas requer uma investigação das raízes sociológicas e jurídico-filosóficas que a fundamentam. Com efeito, Jakobs deixa transparecer suas matrizes teóricas, de maneira a possibilitar uma pesquisa de sua obra de maneira profunda e direta.

\section{1 - Crítica aos fundamentos sociológicos}

A elaboração de um novo sistema jurídico-penal somente foi possível por meio da busca de um referencial externo ao próprio direito penal. Nesse sentido, a originalidade da construção e da fundamentação do direito penal por Günther Jakobs pode ser constatada justamente pela particular concepção de sociedade e pela específica forma de analisá-la na atual conjuntura. Trata-se do funcionalismo sistêmico, referencial teórico da sociologia cujas características centrais foram acima descritas. 
A escolha deste referencial teórico revela em suas raízes não só uma específica forma de analisar a sociedade, como também uma opção política muito clara. A fundamentação que o funcionalismo penal conferiu à pena não foi apenas insatisfatória no plano teórico, como constituiu, em verdade, um conjunto discursivo que serviu muito mais à expansão do poder punitivo do que à garantia da liberdade.

Com efeito, uma análise crítica da teoria da prevenção geral positiva somente se perfaz de maneira consistente caso exceda as fronteiras das manifestações jurídicas e também atinja as raízes dos seus fundamentos sociológicos, os quais constituem, a um só tempo, o alicerce e a marca de originalidade da teoria preventiva em estudo. Pretende-se, pois, o empreendimento de uma crítica radical à prevenção geral positiva cunhada pelo funcionalismo sistêmico de Jakobs.

\subsection{1 - Funcionalismo e conservação da ordem}

A raiz positivista da sociologia funcionalista deixou marcas profundas em todo o seu desenvolvimento como eixo fundamental da teoria social. Mas se o positivismo teve em sua origem um caráter crítico e transformador ${ }^{275}$ para apenas após sua afirmação com Augusto Comte assumir em definitivo seu caráter conservador, o funcionalismo por todo o seu percurso histórico carregou esta qualificação.

A intrínseca relação estabelecida com o positivismo na formação do funcionalismo como corrente da teoria sociológica deixou transparecer os objetivos a que os esforços

\footnotetext{
${ }^{275} \mathrm{Em}$ sua formação embrionária com Condorcet e Saint-Simon no âmbito da filosofia iluminista, o positivismo representou um instrumento crítico em favor dos revolucionários burgueses, mas sua afirmação e desenvolvimento a partir de Augusto Comte constituiu uma ferramenta conservadora da ordem estabelecida, a ordem instituída pela burguesia vitoriosa. Nesse sentido é a precisa análise levada a efeito por Michel Löwy: "Mas, há ainda em Condorcet uma significação crítico-utópica: seu objetivo confesso é o de emancipar o conhecimento social dos "interesses e paixões" das classes dominantes. O cienticismo positivista é aqui um instrumento de luta contra o obscurantismo clerical, as doutrinas teológicas, os argumentos de autoridade, os axiomas a priori da Igreja, os dogmas imutáveis da doutrina social e política feudal. (...) Discípulo de Condorcet e Saint-Simon, Comte irá romper com um discurso cuja carga crítica e "negativa" the parece ultrapassada e perigosa. (...) Representa precisamente o ponto de vista reconhecido da escola positivista moderna nas ciências sociais. Conforme a feliz expressão de George Lichtheim, em Comte 'o otimismo generoso do Iluminismo congelara-se numa inquietude ansiosa para com a estabilidade social"'. LÖWY, Michel. As aventuras de Karl Marx contra o Barão de Münchhausen, cit., p. 22 e 25-26.
} 
científicos se destinavam. Os pressupostos que formam a base do paradigma positivista confundiram-se com a própria metodologia funcionalista em Durkheim, uma vez que este deixou claro considerar que na sociedade reina uma harmonia ou ordem natural e o papel do cientista é a observação dos fenômenos de maneira neutra e objetiva, com a utilização da metodologia das ciências naturais. Com efeito, o método positivista mostrou-se ideal para que a sociologia nascesse com um viés essencialmente conservador.

Se por um lado a defesa da neutralidade do cientista foi vista como uma forma de evitar a contaminação da pesquisa pura, é inegável que também serviu para que o olhar crítico não aflorasse naqueles que tinham por tarefa o estudo da sociedade e das relações que nela se estabeleciam. Se hoje não há como negar que as prenoções e a subjetividade são elementos constitutivos do próprio ponto de vista do cientista, que não é um mero observador de relações causais, naquele momento histórico em que se desenvolvia na França um sindicalismo revolucionário ameaçador ${ }^{276}$, a neutralidade científica cumpria um papel de suporte acrítico da ordem existente.

Ao lado da neutralidade científica havia também o pressuposto da naturalidade da coesão social, ou seja, o ponto de partida da análise social é a consideração de que vigora $a$ priori uma harmonia na sociedade em seu estado normal. E, para caracterizar o funcionamento da sociedade, o organicismo foi o melhor caminho descritivo possível.

A harmonia da sociedade foi descrita como um organismo em que cada instituição desempenharia uma função para a manutenção do todo. Assim como para a manutenção da vida humana cada órgão do corpo desempenha uma função para sua manutenção, na vida social cada instituição exerce uma função para a sustentação da ordem social. Existe uma ordem natural e para sua manutenção papéis são reservados a diferentes formas de manifestação da vida em sociedade.

A análise meramente descritiva e neutra do funcionamento da sociedade aliada à sua pressuposição harmônica e orgânica levou à naturalização das funções ou papéis desempenhados por instituições, indivíduos ou quaisquer outras situações sociologicamente aferíveis como a desigualdade social ou os privilégios sociais. A transposição das leis da seleção natural para as "leis naturais" da sociedade (e dos

${ }^{276}$ LÖWY, Michel. As aventuras de Karl Marx contra o Barão de Münchhausen, cit., p. 32. 
organismos vivos aos “organismos" sociais) ${ }^{277}$ foi a melhor maneira de naturalizar a ordem social existente ${ }^{278}$.

A combinação entre organicismo e neutralidade científica deu ao funcionalismo uma estrutura analítica com limites evidentes: se a função de uma instituição deve corresponder às necessidades do organismo social ${ }^{279}$ e a sociedade deve ser analisada livre de juízos de valor, chega-se à conclusão de que as referidas necessidades correspondem à estrutura social vigente com a desconsideração dos condicionamentos histórico-sociais desta estrutura e do próprio conhecimento científico.

O conservadorismo do funcionalismo é admitido pelo próprio Durkheim no prefácio de As Regras do Método Sociológico ${ }^{280}$, o que certamente está relacionado ao método e às premissas desta corrente da teoria social ${ }^{281}$. Com efeito, as escolhas temáticas e muitas das análises empreendidas pelos funcionalistas deixaram clara esta tendência, que em diversos momentos permaneceu no percurso histórico de seu desenvolvimento na sociologia do século XX.

O traço de maior dificuldade da teoria funcional na sociologia, para os fins do presente trabalho, contudo, é a questão que envolve a ordem e o conflito. O núcleo central do funcionalismo sociológico é a compreensão da ordem ou harmonia social e das funções que cada instituição desempenha para a manutenção dessa ordem estabelecida. Não por acaso, a obra de Émile Durkheim não trabalha com o conceito sociológico de classe social, bem como passa ao largo das principais contradições e dificuldades do capitalismo vigente

\footnotetext{
${ }^{277}$ LÖWY, Michel. As aventuras de Karl Marx contra o Barão de Münchhausen, cit., p. 34.

${ }^{278}$ Nesse sentido é paradigmática a passagem contida na obra de Durkheim quando trata das diferentes posições dos órgãos e seus papéis na sociedade orgânica: "Sem dúvida, ele ainda tem uma situação particular e, se quiserem, privilegiada; mas ela se deve à natureza do papel que desempenha e não a alguma causa alheia a suas funções, a alguma força que lhe é comunicada de fora. (...). Assim, no animal a preeminência do sistema nervoso sobre os outros sistemas se reduz ao direito, se é que se pode falar assim, de receber uma alimentação mais escolhida e apropriar-se da parte que lhe cabe antes dos outros; mas necessita deles, como eles dele necessitam.” DURKHEIM, Émile. Da divisão do trabalho social, cit., p. 165.

${ }^{279} \mathrm{Cf}$. BOTTOMORE, Tom. Introdução à sociologia, cit. p. 65.

280 "Nosso método, portanto, nada tem de revolucionário. Num certo sentido, é até essencialmente conservador, pois considera os fatos sociais como coisas cuja natureza, ainda que dócil e maleável, não é modificável à vontade.” DURKHEIM, Émile. As regras do método sociológico, cit., p. XIII.

${ }^{281}$ Nesse sentido é também a avaliação de Michel Löwy: "o conservadorismo de Durkheim se situa num nível muito mais profundo: na sua própria concepção do método. É seu método positivista que permite legitimar constantemente, através de argumentos científico-naturais, a ordem (burguesa) estabelecida. Este conservadorismo fundamental, inerente a toda démarche metodológica de Durkheim, pode ser conciliado tanto com o "racionalismo individualista" como com o "autoritarismo", tanto com o liberalismo como com o tradicionalismo, ou ainda com uma combinação sui generis dos dois (que é provavelmente a característica central do pensamento de Durkheim).” LÖWY, Michel, op. cit., p. 34.
} 
na sociedade por ele estudada ${ }^{282}$. Com efeito, Randall Collins aponta que a diferenciação entre estados normais e patológicos desenvolvida pelo sociólogo francês muitas vezes serviu para desqualificar os conflitos inerentes à vida em sociedade ao invés de enfrentalos, pois "em vez de tentar compreender realisticamente os conflitos de interesse que constituem uma sociedade real, Durkheim condena alguns deles (aqueles com os quais não concorda) como meramente patológicos

Se com a evolução do funcionalismo algumas características típicas da influência positivista sofreram atenuações e transformações, a base fundamental que caracteriza esta corrente da teoria sociológica, aquilo que a distingue como tradição sociológica original, se manteve como ponto de partida das análises empreendidas pelos seus seguidores: estudo da sociedade como uma ordem harmônica a partir das funções exercidas pelas instituições para a manutenção desta mesma ordem.

Nem mesmo vertentes funcionalistas que instigaram seus seguidores a investigarem para além da superfície ao difundir a diferenciação entre funções manifestas e funções latentes das instituições ${ }^{284}$, foram capazes de imprimir um viés crítico a esta vertente da teoria social. A desconsideração dos conflitos e relações de dominação no seio social não permitiu uma análise crítica da sociedade. Com efeito, as funções latentes das instituições pesquisadas não eram estudadas sob o ponto de vista dos interesses de determinados grupos sociais, senão que os estudos nela baseados em geral desviaram a atenção do conflito para um juízo abstrato, pelo qual o objeto de estudo serviria a alguma função latente. A análise das funções, ainda que diferenciadas em manifestas e latentes, no bojo de um arcabouço teórico que parte do pressuposto da ordem na sociedade não só impede como encobre os reais conflitos existentes na dinâmica social. Conforme aponta Randall Collins, "a terminologia funcionalista impede que esse insight possa ser levado mais adiante, 285 .

\footnotetext{
${ }^{282}$ Nesse sentido, cf. Lições de Sociologia do Direito, cit., p. 78.

${ }^{283}$ COLLINS, Randall. Quatro tradições sociológicas, cit., p. 161.

${ }^{284}$ Cf., MERTON, Robert K.. Teoría y estructura sociales. 4. ed. Trad. Florentino Torner e Rufina Borques. México: Fondo de Cultura Económica, 2010.

285 “Na verdade, nesse sentido é sempre possível encontrar uma função para tudo. Mas falar sobre funções e sobre a manutenção da ordem social é um equívoco, se a discussão parar por aí. Não é a sociedade como um todo que se beneficia de determinado arranjo particular, mas cada grupo tem sua própria visão a respeito da ordem social que se está tentando manter. Nesse sentido, o funcionalismo de Merton contribui para obscurecer os esclarecimentos trazidos pela perspectiva do conflito." COLLINS, Randall, op. cit., p. 172.
} 
Não é por acaso que no auge do funcionalismo estadunidense, quando temas mais relacionados aos conflitos e diferenças sociais foram enfrentados, a ideia era sua legitimação pela função que tais questões exerciam para a manutenção da sociedade. É o caso do clássico estudo sobre a estratificação social levado a efeito por Kingsley Davis e Wilbert Moore com base na ideia de necessidade funcional. Os autores defenderam que os trabalhos mais complexos e difíceis na sociedade são os mais necessários e exigem as maiores retribuições como forma de motivação das pessoas para cumprirem tais tarefas nas diversas áreas. Assim, a estratificação social e a desigualdade são mecanismos cuja função exercida consiste em garantir a máxima eficiência da sociedade ${ }^{286}$.

Por sua vez, o funcionalismo levado a efeito por Talcott Parsons e sua complexa análise do sistema social tampouco foi capaz de empreender uma análise crítica dos conflitos e das relações de poder na sociedade. Ao explorar uma análise mais descritiva e conceitual dos fenômenos e de considerar que o destino de todas as sociedades tende a culminar na democracia, interpretava fenômenos delicados e conflitivos da história como obstáculos temporários de melhorias a longo prazo, mas não em suas raízes de conflitos de interesses $^{287}$.

Com efeito, o funcionalismo na sociologia é considerado por grande parte dos cientistas sociais como uma ideologia conservadora, principalmente por sua preocupação com a ordem e a pouca relevância conferida aos conflitos e relações de poder na sociedade. Nesse sentido, Randall Collins assevera: "não importa quais fossem os acontecimentos, eles sempre concorreriam para o melhor, ou seriam somente um estágio temporário que estaria no meio do caminho para melhorias de longo prazo"288.

Até mesmo autores como George Ritzer, que ressalta mais o uso conservador do que o conservadorismo propriamente dito do funcionalismo estrutural, acaba por admitir que provavelmente exista uma inclinação conservadora nesta corrente sociológica não só pela forma como analisa (quando analisa) as questões como a transformação social, o

\footnotetext{
${ }^{286}$ Cf. DAVIS, Kingsley; MOORE, Wilbert. Some principles of stratification. American Sociological Review, vol. 10, n. 02, 1944, p. 242-249.

${ }^{287}$ Cf. COLLINS, Randall. Quatro tradições sociológicas, cit., p. 175, para quem Parsons e seu colaboradores tendiam a considerar qualquer insatisfação social ou revolta como um tipo de mudança social meramente temporária. Cf. PARSONS, Talcott. El sistema social, p. 332-333.

${ }^{288}$ COLLINS, Randall, op. cit., p. 175.
} 
condicionamento histórico dos acontecimentos e o conflito social, como também pela eleição dos temas de investigação ${ }^{289}$.

Com razão está a precisa análise de Alaôr Caffé Alves quando assinala que ao desconhecer, desvalorizar ou desprezar referências que não contribuam a favor de uma análise da permanência e continuidade das formas sociais básicas, sempre assimiladas a um sistema complexo de papéis diferenciados e integrados, o funcionalismo representa um obstáculo epistemológico à real compreensão dos fatores coletivos determinantes das transformações sociais. Ao dedicar toda sua atenção aos fatores que consolidam a coesão social, o funcionalismo não qualifica a prática social no sentido de apurar efetivamente o beneficiário da reprodução material da sociedade e as consequências dos conflitos a ela inerentes. As questões substantivas de uma análise social crítica são ignoradas por essa vertente sociológica, que acaba por gerar um ocultamento das contradições da estrutura social em benefício da entronização da ordem e da estabilidade institucional ${ }^{290}$.

Embora tenha sido a teoria sociológica dominante nos Estados Unidos desde finais da década de 1930 até o início dos anos de 1960, a partir de então as críticas recebidas fizeram com que o funcionalismo fosse relegado a um segundo plano dentro da sociologia, especialmente pelo surgimento de um ambiente político-social mais progressista que se formava $^{291}$. Coube a Niklas Luhmann, discípulo de Talcott Parsons, reintroduzir sua vertente funcionalista da teoria dos sistemas novamente no debate das ciências sociais.

\footnotetext{
${ }^{289}$ RITZER, George. Teoría Sociológica Moderna, cit., p. 141.

${ }^{290}$ ALVES, Alaôr Caffé. Estado e ideologia: aparência e realidade. São Paulo: Brasiliense, 1987, p. 92-94.

${ }^{291}$ Sua influência na América Latina que era ampla até então também começou a reduzir a partir da década de 1960, como aponta Emilio García Méndez: “A perda de influência das concepções funcionalistas na década de '60 coincide com um duplo processo: a) a mobilização popular em torno de propostas políticoideológicas que questionam os interesses da classe dominante; b) o desenvolvimento, em suas distintas variantes, da "Teoria da Dependência", que se apresentou como ferramenta teórica apta para pôr em evidência a função conservadora e mistificadora das propostas funcionalistas.” GARCÍA MÉNDEZ, Emilio. Autoritarismo y control social: Argentina, Uruguay, Chile. Buenos Aires: Editorial Hammurabi, 1987, p. 118 , nota de rodapé 5 .
} 


\subsection{2 - Crítica ao funcionalismo sistêmico de Niklas Luhmann}

O desenvolvimento que Niklas Luhmann conferiu à obra de Talcott Parsons trouxe inovações e complexidade em termos teóricos. Luhmann tentou responder a diversas críticas que foram lançadas ao funcionalismo e elaborou uma perspectiva sociológica de amplo alcance com a teoria dos sistemas. A diversidade temática das investigações, a abstração de sua produção e a coerência lógica de seus argumentos exerceram curiosa influência no âmbito das ciências sociais, o que fez com que angariasse seguidores das mais diversas inspirações político-ideológicas ${ }^{292}$.

Com efeito, a diversidade conceitual e o alto nível de abstração de sua teoria sociológica permitiram sua utilização como base teórica para diversos campos do conhecimento e por variados pesquisadores nas ciências sociais. Contudo, observa-se que ao invés de tal facilidade de acomodação às distintas circunstâncias constituir um mérito, representa o maior perigo de sua teoria, pois é capaz de prover elementos de legitimação de qualquer tipo de sistema cujo objetivo seja o de alcançar um funcionamento eficiente de sua própria ordem ${ }^{293}$.

O núcleo fundamental dos pressupostos clássicos do funcionalismo não foi revertido por Luhmann e sua tentativa de dar novo formato às críticas que referida teoria sociológica recebera restou ilusória ${ }^{294}$. Sua teoria continua tendo como objetivo e pressuposto fático a estabilidade e conservação do sistema social, bem como a consideração dos conflitos e crises sociais como circunstâncias excepcionais. Parece inegável que o discurso luhmanniano constitui mais uma versão de legitimação das estruturas vigentes na sociedade no plano sociológico ${ }^{295}$.

\footnotetext{
${ }^{292}$ Cf. FERRARI, Vicenzo. Funciones del Derecho. Tradução de Maria José Añon Roig e Javier de Lucas Martin. Madrid: Editorial Debate, 1989, p. 42.

${ }^{293}$ Nesse sentido, cf. GARCÍA MÉNDEZ, Emilio. Autoritarismo y control social, cit., p. 118-119.

${ }^{294}$ FERRARI, Vicenzo, op. cit., p. 46.

${ }^{295}$ No mesmo sentido são as precisas palavras de Pietro Barcellona: "O sistema construído por Luhmann é em realidade uma tentativa sub-reptícia de bloquear o devir, o tempo histórico, e de legitimar as instituições existentes como estruturas imutáveis, como formas últimas e definitivas da experiência vivente. (...) No plano histórico tudo isto assume um significado muito preciso. A estabilização do sistema, sua duração, é a estabilização das regras do jogo, da compatibilidade definida e calculada pelo sujeito histórico que a projetou e produziu: burguesia-capital.” BARCELLONA, Pietro. La teoria de sistemas y el paradigma de la sociedade moderna. Trad. de Mariano Maresca. In. Mutaciones del Leviatán. Legitimación de los nuevos modelos penales. PORTILLA CONTRERAS, Guillermo (coord.). Madrid: Akal, 2005, p. 50-51.
} 
Se a análise do papel de determinada teoria depende menos da vontade do seu autor do que de sua consideração objetiva como mecanismo de ocultamento e mistificação da realidade social ${ }^{296}$, além do uso que pode ser feito nesse sentido, é possível dizer que o viés conservador do funcionalismo sistêmico não foi utilizado por acaso como base teórica para o sistema de direito penal desenvolvido por Günther Jakobs.

Nesse sentido, alguns aspectos específicos do funcionalismo luhmanniano podem ser destacados para os fins que se pretendem atingir no presente trabalho. Primeiramente cumpre destacar que a coerência lógica de um conjunto teórico não constitui por si só uma qualidade se o papel que realmente desempenha pode ser negativo do ponto de vista das possibilidades de transformação social e imobilização de análises críticas dos fenômenos estudados. Essa característica da coerência lógica, que é comum na doutrina penal de Jakobs $^{297}$, associada à abstração com que a sua teoria é apresentada, permitem que se mantenha em baixo nível de visibilidade sua concepção particular de mundo ${ }^{298}$. Assim, a falta de concretude na análise social e de posicionamento real diante dos problemas enfrentados acabam por identificar a defesa de manutenção da ordem uma vez mais com a defesa da ordem social vigente qualquer que ela seja ${ }^{299}$.

As ideias e conceitos cunhados pelo funcionalismo sistêmico, tais como a de estabilização de expectativas e a de manutenção do sistema social mediante a neutralização de comportamentos nocivos à ordem estabelecida fornecem elementos para a construção de teorias autoritárias no que se refere a formas de controle social punitivo ${ }^{300}$, o que de fato foi realizado por Jakobs.

\footnotetext{
${ }^{296}$ Nesse sentido, cf. GARCIA MENDEZ, Emilio, op. cit., p. 119.

${ }^{297}$ Sobre o "falso mérito" da coerência lógica do pensamento de Jakobs, Ana Elisa Liberatore Silva Bechara aponta criticamente: "O conhecimento da realidade jurídica não pode ser limitado à construção de um universo conceitual abstrato no qual cada dispositivo legal ocupe um lugar sistematicamente preciso de contornos definidos. Ao contrário, a norma jurídico-penal necessariamente tem vocação de transcendência, devendo responder a conflitos sociais reais.” BECHARA, Ana Elisa Liberatore Silva. Bem jurídico-penal, cit., p. 298.

${ }^{298}$ Guillermo Portilla Contreras, todavia, se arrisca a desvelar a concepção de mundo de Niklas Luhmann quando assevera: "Uma teoria que se funda na proteção da propriedade privada, a globalização econômica, a liberação dos mercados e que, como é lógico, necessita da abstração do Direito para a conservação desses interesses através de uma autolegitimação normativa.” PORTILLA CONTRERAS, Guillermo. Los excesos del formalismo jurídico neofuncionalista en el normativismo del Derecho penal, cit., p. 58.

${ }^{299}$ GARCÍA MÉNDEZ, Emilio. Autoritarismo y control social, cit., p. 122.

${ }^{300}$ Interessante notar que em importante trabalho sobre autoritarismo e controle social desenvolvido nos primeiros anos da década de 1980, e somente publicado na Argentina em 1987, Emilio García Méndez dedica um capítulo para a análise da obra de Niklas Luhmann e aponta as semelhanças com a doutrina da segurança nacional que sustentou as ditaduras na América Latina, além do risco de sua utilização para construção de teorias de controle social punitivo. Aparentemente o autor ainda desconhecia o sistema de
} 
Por outro lado, a separação radical dos sujeitos dos sistemas sociais ou o que se chamou da elaboração de uma "sociedade sem homens" também possibilitaram um conceito de pessoa no direito penal de Jakobs bastante peculiar a ponto de excluir essa condição de alguns sujeitos na sociedade, conforme exposto acima. Pietro Barcellona chega a qualificar o sociólogo alemão como "o estudioso mais radical em assumir uma perspectiva anti-humanista, onde a ciência se torna um puro cálculo de possibilidades abstratas."301

Outro ponto fundamental da obra de Niklas Luhmann que cumpre analisar criticamente é a continuidade do viés funcionalista no que se refere à análise dos conflitos sociais. Seguindo a tradição funcionalista, os conflitos sociais ou crises não constituem objetos centrais de análise e continuam a ser caracterizadas por Luhmann como circunstâncias excepcionais. Se a descrição se mantém, a prescrição do sociólogo alemão para situações de crise são particularmente delicadas do ponto de vista do Estado de Direito.

Com efeito, em sua obra "Poder" o autor aventa com a possibilidade de enfrentamento de crises na sociedade por meio de legislação de emergência e de programas de exceção ${ }^{302}$. A abertura excepcional de regimes de emergência combinada ao conceito funcionalizado de pessoa serviram de base para a criação do chamado direito penal do inimigo no âmbito da doutrina penal. Os riscos denunciados por Emilio García Méndez e Bernhard Heidtmann ${ }^{303}$ de elaboração de um estado de exceção a partir do funcionalismo sistêmico mediante processos de planificação técnico-jurídica teve, de fato, sua elaboração teórica no âmbito da doutrina penal com a obra de Günther Jakobs.

Se a influência da sociologia funcionalista sistêmica na obra de Günther Jakobs é inegável, também o são seus objetivos com esta base teórica: construir um discurso jurídico penal que contribua para a manutenção da ordem social vigente.

direito penal cunhado por Günther Jakobs, de modo que pode ter cunhado uma curiosa e acertada previsão. Cf. ibidem, p 117 e ss.

${ }^{301}$ BARCELLONA, Pietro. Oltre lo stato sociale: economia e politica nella crisi dello Stato keynesiano. Bari: De Donato, 1980, p. 8.

${ }^{302}$ Cf. LUHMANN, Niklas. Poder. Trad. de Luz Mónica Talbot. Barcelona: Anthropos, 1995, p. 125.

${ }^{303}$ Cf. GARCÍA MÉNDEZ, Emilio. Autoritarismo y control social, cit., p. 126. 


\section{2 - Crítica das bases jurídico-filosóficas do pensamento de Günther Jakobs}

Se no campo sociológico a influência do funcionalismo transparece na obra de Günther Jakobs, não menos importante mostra-se a análise de seu pensamento à luz da filosofia do direito. Com efeito, a adoção do funcionalismo sistêmico faz transparecer a profunda relação existente entre a sociologia de Niklas Luhmann e a doutrina penal de Günther Jakobs com o normativismo positivista de Hans Kelsen ${ }^{304}$. A adoção do funcionalismo sistêmico como base sociológica de construção do direito permite que esta edificação se aproxime em diversos pontos da filosofia jurídica positivista e, por consequência, receba também sob este viés as críticas que se consolidaram sobre o normativismo kelseniano.

Ainda que a relação entre os autores não seja livre de contradições decorrentes das distintas influências científicas que receberam Luhmann e Kelsen, a relação entre estes e o sistema de direito penal de Jakobs é intensa e deve ser destacada especialmente com relação ao pressuposto fundamental da autorreferencialidade do direito e ao conceito de pessoa que adotam os autores, cujas consequências no plano das ideias bem como no plano prático também possuem estreita relação.

\subsection{1 - Direito e ausência de suporte material}

Principal corrente de oposição à doutrina do direito natural no âmbito da filosofia do direito, o positivismo jurídico dominou o cenário jurídico romano-germânico a partir do século XIX com o movimento da codificação e a Escola da Exegese. O positivismo

\footnotetext{
${ }^{304}$ No mesmo sentido é a advertência de Guillermo Portilla Contreras: "Existe uma profunda inter-relação entre o formalismo jurídico, o funcionalismo sociológico e o normativismo de Jakobs. Ainda que essa conexão, como veremos, não esteja isenta de contradições. Os une a consideração do Direito como instrumento para conseguir a estabilização de expectativas normativas, o desaparecimento do sujeito como autonomia consciente e sua substituição pelo indivíduo dependendo do meio (Umwelt): em suma, a permanente autorreferência do Direito". PORTILLA CONTRERAS, Guillermo. Los excesos del formalismo jurídico neofuncionalista en el normativismo del Derecho penal, cit., p. 57.
} 
jurídico solidificou-se cientificamente com o pensamento de Hans Kelsen e até os dias atuais exerce grande influência no cotidiano dos juristas, tanto na academia quanto nos profissionais do sistema de justiça ${ }^{305}$.

Necessidade da burguesia vitoriosa ${ }^{306}$ no contexto histórico da formação do Estado Moderno e do consequente processo de monopolização da produção jurídica, o positivismo jurídico proclama a exclusividade do direito como aquele emanado do poder estatal. $\mathrm{O}$ positivismo jurídico nega o reconhecimento de direitos que não sejam aqueles positivados pelo Estado e confunde o direito com a própria lei.

À monopolização do direito pelo Estado segue um grande movimento codificador destinado a prever todas as situações jurídicas possíveis e criar um grande complexo racional e sistemático de normas. Se o Estado é o criador de todo o direito por meio do legislador, cumpre ao juiz ser um mero aplicador da lei, representando a famosa figura da "boca da lei".

Coube ao austríaco Hans Kelsen, o jurista mais influente do século XX, o trabalho de consolidação científica do positivismo jurídico. Com extrema coerência lógica e a influência metodológica do neokantismo, objetivava purificar o fenômeno jurídico das influências que eram admitidas por outras correntes jusfilosóficas e descrever objetiva e normativamente o direito. Em Kelsen, o objeto da ciência jurídica é identificado com a norma, que se traduz em um juízo hipotético de dever-ser, ou seja, uma proposição, algo que deve ser. A proposta de uma ciência puramente normativa, no entanto, impede que o direito seja analisado no campo de sua manifestação concreta, o que só seria possível a partir de outros campos científicos, como a história e a sociologia ${ }^{307}$.

Se o objeto da ciência pura do direito é a norma, o método é o lógico-formal. A ciência jurídica almejada pelo positivista austríaco utiliza-se do método lógico-formal para

\footnotetext{
${ }^{305}$ Curioso notar que pela influência do positivismo jurídico, os juristas passaram a ser chamados de "operadores do direito", o que denota, conforme demonstrou Caio Jesus Granduque José “a adesão, ainda que inconsciente, ao modelo positivista de juridicidade, segundo o qual o fenômeno jurídico é criado pelo legislador e, por já estar dado, pronto e acabado, aplicado por advogados, defensores públicos, promotores de justiça e juízes de direito.” JOSÉ, Caio Jesus Granduque. A construção existencial dos direitos humanos. Curitiba: CRV, 2012, p. 108

306 “O jusnaturalismo correspondia, sobretudo no fim do século XVIII, à teoria de que necessitava a burguesia ascendente para criticar a feudalidade e transformar a sociedade que se opunha ainda à sua dominação. O positivismo será, a partir da codificação napoleônica (de que é uma manifestação e não uma causa), a teoria de que se tem necessidade uma burguesia que se tornou dominante no sistema sociopolítico. Depois da escola da crítica segue-se a da exegese!” MIAILLE, Michel. Introdução crítica ao direito. Trad. Ana Prata. 3. ed. Lisboa: Estampa, 2005, p. 44.

${ }^{307}$ MASCARO, Alysson Leandro. Filosofia do direito. São Paulo: Atlas, 2010, p. 343.
} 
captar o direito, com objetivo central de ser "capaz de compreender tanto as estruturas lógicas das normas e a concordância entre elas, quando o conjunto de formalidades abstratas por elas enunciadas

Para o normativismo kelseniano, o direito é definido como um sistema de normas que regulam o comportamento humano, enquanto o objeto da ciência do direito são as normas jurídicas propriamente ditas. $\mathrm{O}$ ordenamento jurídico é descrito pelo teórico positivista como uma ordem escalonada de normas ${ }^{309}$, que se autocriam e encontram o fundamento de validade na norma do nível superior num processo de supraordenação e infraordenação ${ }^{310}$. No patamar mais alto da chamada pirâmide escalonada de normas, como fundamento de validade das demais, encontra-se a constituição, que por sua vez retira o seu fundamento de validade da norma hipotética fundamental (Grundnorm), que não é uma norma de direito positivo como as demais, mas uma norma pressuposta cujo sentido revela que devemos conduzir-nos como a primeira constituição histórica prescreve $^{311}$.

O formalismo que caracteriza a teoria pura do direito relega ao jurista a análise das normas jurídicas (estática do direito) e o exame das competências dos órgãos estatais e do procedimento formal de criação das normas (dinâmica do direito). A tarefa do jurista, portanto, é a descrição objetivada do ordenamento jurídico tal qual ele se apresenta, do ordenamento posto pelo Estado, o direito positivo.

É justamente nesta descrição objetivada do ordenamento jurídico que reside a característica marcante do pensamento kelseniano e que o assemelha especialmente aos resultados advindos do funcionalismo sistêmico na sociologia e no direito penal. Com efeito, a pureza buscada para a elaboração de uma ciência do direito consistia na eliminação de juízos de valor por parte do jurista na análise do fenômeno jurídico, ou seja, requeria uma descrição objetiva das normas jurídicas postas, o que confere uma inegável dimensão positivista ao conjunto teórico de Kelsen $^{312}$.

Como a dimensão histórico-social do direito e os efeitos de sua manifestação concreta na vida social estão fora da alçada do jurista, o purismo formalista apregoado por

\footnotetext{
${ }^{308}$ MACHADO, Antônio Alberto. Ensino jurídico e mudança social. 2. ed. São Paulo: Atlas, 2009, p. 24.

${ }^{309}$ KELSEN, Hans. Teoria pura do direito, cit, p. 33.

${ }^{310}$ JOSÉ, Caio Jesus Granduque. A construção existencial dos direitos humanos, cit., p. 114.

${ }^{311}$ KELSEN, Hans, op. cit., p. 224-225.

${ }^{312}$ Cf. LÖWY, Michel. LÖWY, Michel. As aventuras de Karl Marx contra o Barão de Münchhausen, cit., p. 20.
} 
Kelsen conduz a uma identificação da justiça com a ordem jurídica posta ${ }^{313}$. As normas são em si mesmas um valor a ser preservado, sendo vedado ao jurista aferir juízos valorativos acerca de sua justeza ou mesmo efetuar relações do fenômeno jurídico com a sociedade. O juízo a ser feito é de validade, não de justiça, sendo não só possível como devida a aplicação de leis injustas, pouco importando se a norma se materializa ou não em um exercício de liberdade do sujeito por ela afetado, por exemplo.

A teoria pura do direito implica uma relação passiva do jurista com a ordem jurídica vigente, uma relação de objetividade que culmina na sua aceitação. A ausência de referenciais externos para análise da legitimidade do direito, que acaba por se confundir com um juízo de validade interno, resulta em uma posição conservadora diante do fenômeno jurídico, uma vez que o jurista torna-se um sujeito inerte quanto a situações concretas de injustiça que o direito pode legitimar.

O normativismo kelseniano foi duramente criticado não só por restringir o fenômeno jurídico à lei e por ter reduzido a filosofia do direito àquilo que se chamou de teoria geral do direito ${ }^{314}$, como também por sua postura de defesa da norma, da ordem jurídica posta, qualquer que seja ela, sendo, portanto, capaz de legitimar qualquer modelo de Estado ou de política estatal que se manifeste normativamente.

Por sua vez, a sociologia jurídica de Niklas Luhmann também compreende o direito como um sistema de normas que materializam as expectativas comportamentais. $\mathrm{O}$ sociólogo alemão igualmente adota como pressuposto que o direito nas sociedades contemporâneas é o direito positivo hierarquicamente constituído. O sistema jurídico se renova internamente e tem como referencial para tanto o próprio sistema jurídico. Além de autorreferencial e autopoiético ${ }^{315}$, o sistema jurídico na sociologia luhmanniana é também fechado. As referências que recebe de seu entorno são recebidas e apreendidas pelos critérios estabelecidos pelo próprio sistema jurídico segundo o critério da legalidade.

\footnotetext{
${ }^{313}$ JOSÉ, Caio Jesus Granduque. A construção existencial dos direitos humanos, cit., p. 120.

314 "Hans Kelsen, em toda sua obra e, em especial, na Teoria Pura do Direito, pretendeu reduzir a compreensão do direito ao estudo apenas das normas jurídicas. Tal seria, para Kelsen, um fundamento técnico universal para todos os direitos, mas o que se dava era uma grande teoria geral de todos os ferramentais normativos do direito moderno, que é sim essencialmente estatal. Kelsen chamou a isso de ciência do direito quando, na verdade, tratava-se de uma teoria geral sobre as técnicas jurídicas modernas." MASCARO, Alysson Leandro. Introdução ao estudo do direito. São Paulo: Quartier Latin, 2007, p. 61.

${ }^{315}$ Antevendo uma visão autopoiética do direito já no normativismo propugnado por Hans Kelsen, cf. OLIVEIRA JUNIOR, José Alcebíades de. Teoria jurídica e novos direitos. Rio de Janeiro: Lumen Juris, 2000, p. 190.
} 
Além do limite da interferência externa ser determinado pelo sistema jurídico que a recebe, o filtro e a leitura da relação do sistema jurídico com o seu entorno se limitam à questão da legalidade. Legalidade e legitimidade mais uma vez aqui se relacionam de maneira profunda, uma vez que não há referenciais externos para a análise da legitimidade do direito, ou seja, a apreciação do direito não tem qualquer referencial axiológico para além dele mesmo.

Sobre a ausência de consideração de fatores externos ao direito pelo funcionalismo sistêmico, expressiva é a lição de Alaôr Caffé Alves quando assevera que referida vertente teórica é a expressão de uma lógica da circularidade tautológica, de uma lógica da redundância que está condenada a se abrir permanentemente ao entorno, a romper paradoxal e continuamente sua própria circularidade em prol da materialidade de seu meio ambiente, sob pena de não ser útil no mundo dos fatos sociais. ${ }^{316}$

Se o ponto de partida na elaboração do sistema jurídico de cada autor adota um referencial distinto, o ponto de chegada se aproxima profundamente no resultado: o direito como sistema de normas positivadas, neutro, isento de referenciais externos e, inevitavelmente, legitimador da ordem social vigente. A análise do fenômeno jurídico de ambos os autores, por mais complexa que seja do ponto de vista lógico-sistemático, representa uma análise neutra e, portanto, superficial do direito.

Contudo, há uma diferença fundamental no nível de encerramento do sistema jurídico: enquanto a vertente sistêmica do funcionalismo postula a existência de um nível social que seja só jurídico, diferente dos outros níveis, econômicos, morais, políticos e sociais, por exemplo, o positivismo jurídico de Kelsen estabelece uma diferença entre o direito e a ciência do direito. Quando Kelsen elabora a ciência pura do direito como unidade lógica, não deixa de reconhecer que o direito como fenômeno social não é fechado, senão que realiza um corte epistemológico que reserva ao jurista tão somente o estudo objetivo da norma jurídica ${ }^{317}$. Já Luhmann vai além e postula um sistema fechado propriamente jurídico, de modo a radicalizar ainda mais o encerramento do direito ${ }^{318}$.

\footnotetext{
${ }^{316}$ ALVES, Alaôr Caffé. Dialética e direito: linguagem, sentido e realidade. Barueri: Manole, 2010. p. 100.

317 “O Direito pode ser objeto de diversas ciências; a Teoria Pura do Direito nunca pretendeu ser a única ciência do Direito possível ou legítima. A sociologia do Direito e a história do Direito são outras. Elas, juntamente com a análise estrutural do Direito, são necessárias para uma compreensão completa do fenômenos complexo do Direito." KELSEN, Hans. O que é justiça?: a justiça, o direito e a política no espelho da ciência. Tradução de Luís Carlos Borges. 3.ed. São Paulo: Martins Fontes, 2001, p. 291-292.

318 "Luhmann, ao postular uma sociologia do direito dos sistemas, é conservador, e não porque postule o estudo do direito como fechado, mas sim o próprio fenômeno jurídico. Não é a ciência do direito, mas, antes,
} 
A doutrina penal de Günther Jakobs também assume uma relação próxima ao positivismo jurídico de Hans Kelsen em diversos aspectos. Com efeito, em nenhum outro penalista o aspecto da autorreferencialidade do direito é tão marcante quanto em Jakobs. Além de elaborar um sistema de direito penal neutro e coerentemente lógico, o normativismo de Jakobs experimenta níveis extremos em dois pontos fundamentais para a verificação da legitimidade do próprio direito penal: o processo da criminalização primária e a teoria da pena.

Jakobs procede a uma desmaterialização do delito que subsiste pelo simples fato de estar tipificado como tal. Não existe qualquer referencial externo ao direito que possa servir de parâmetro para a incriminação de condutas, de modo que a tipificação passa a depender apenas de aspectos formais. O conteúdo material do delito é insignificante para Jakobs, que procede a um verdadeiro suicídio da teoria do bem jurídico com a sua radical equiparação à própria norma jurídico-penal ${ }^{319}$.

O direito penal protege, segundo tal entendimento, a validade da norma. No caso de crimes contra a propriedade, não é a coisa alheia ou a relação do proprietário com a coisa que é protegida pelo direito penal, mas a própria validade do conteúdo da norma que protege a propriedade ${ }^{320}$. O bem jurídico-penal confunde-se com a própria norma e o delito se configura como uma infidelidade ao ordenamento jurídico.

O papel do jurista na análise do direito penal fica muito claro quando Jakobs passa a responder as críticas que sofrera no sentido de que sua teoria poderia assumir um caráter autoritário e legitimador de um excessivo processo de criminalização e redução de liberdades. Em resposta, o professor alemão deixa claro que "a decisão acerca de se tratar de um processo de criminalização excessivo ou desnecessário, ou, ao contrário, da necessária defesa do nuclear é puramente política, não jurídico-penal"321.

De maneira coerente, funda a teoria da prevenção geral positiva, objeto do presente trabalho, em termos estritamente normativos: a função da pena é a estabilização do sistema

a própria manifestação social do direito que é autopoiética, enclausurada, dotada de lógica autônoma, sem interferências diretas imediatas com a sociedade. Claro está que se trata, em Luhmann, de uma constatação sociológica, e não de um conclame teórico. Kelsen, pelo contrário, fez um conclame teórico, científico, e não uma mera constatação, porque não falava como sociólogo do direito.”. MASCARO, Alysson Leandro. Lições de Sociologia do Direito, cit., p. 125.

${ }^{319}$ Cf. BECHARA, Ana Elisa Liberatore Silva. Bem jurídico-penal, cit., p. 289 e ss.

${ }^{320}$ JAKOBS, Günther. Derecho penal, cit., p. 46- 47.

${ }^{321}$ JAKOBS, Günther. Sociedad, norma y persona en una teoría de un derecho penal funcional, cit, p.4041 . 
social por meio da proteção da norma jurídica. Em última instância, a norma é o epicentro do sistema de direito penal de Jakobs, que se apresenta como um herdeiro tardio e não declarado do positivismo jurídico kelseniano.

As semelhanças entre o normativismo de Hans Kelsen, o funcionalismo sistêmico de Niklas Luhmann e o sistema de direito penal de Günther Jakobs ficam mais claras com a consagração de um modelo de direito que se declara neutro, mas que termina por garantir as relações de dominação sob a aparência de uma ciência objetiva e imparcial ${ }^{322}$. A neutralidade e autorreferencialidade do direito são atributos que inevitavelmente contribuem de maneira decisiva para a manutenção da ordem vigente, seja ela qual for.

Nesse sentido, Guillermo Portilla Contreras destaca aquilo que classifica como uma evidente incongruência, pois "enquanto o direito é o terreno no qual se suscitam os

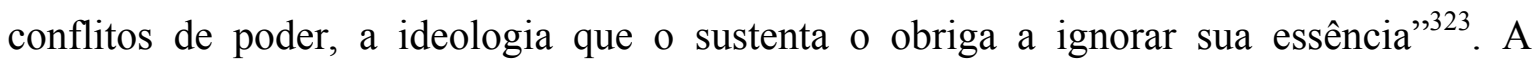
neutralização dos conflitos sociais e das relações de poder que grassam na sociedade só é possível com uma concepção de direito que exclua de sua base de análise critérios externos a ele mesmo, ou seja, quando encontra em si mesmo o fundamento de legitimidade das normas.

Com efeito, a proximidade entre os três autores permite afirmar que suas propostas teóricas culminam em um idealismo abstrato, que, como tal, "sempre acabam por negar o valor reflexivo do discurso jurídico e o seu compromisso com a realização de valores no plano concreto e histórico." 324

A prevenção geral positiva de Jakobs orientada à manutenção do sistema social se configura em uma teoria da pena que impõe o exercício de fidelidade ao direito sem que se possibilite o questionamento dos interesses políticos que subjazem o sistema normativo para o qual se requer a fidelidade. Trata-se, portanto de um discurso penal que perfilha o positivismo de Kelsen e supera os limites da teoria sistêmica para se transfigurar em uma técnica penal que não permite qualquer restrição ao poder punitivo e "facilita o

\footnotetext{
${ }^{322}$ No mesmo sentido é a opinião de PORTILLA CONTRERAS, para quem a associação dos três autores em torno de um direito neutro "perpetua as relações econômicas sob a aparência de uma igualdade formal que coexiste com a desigualdade dos não-possuidores; são teorias, pois, imprescindíveis para a obtenção do consenso que necessita o sistema econômico em seu desenvolvimento." PORTILLA CONTRERAS, Guillermo. Los excesos del formalismo jurídico neofuncionalista en el normativismo del Derecho penal, cit., p. $57-58$

${ }^{323}$ ibidem, p. 58.

${ }^{324}$ MACHADO, Antônio Alberto. Ensino jurídico e mudança social, cit., p. 25.
} 
aprofundamento na consciência social do valor moral mediante a interiorização coletiva da fidelidade normativa ao esquema de reprodução dos valores vigentes"325.

A autorreferencialidade do direito tem consequências concretas absolutamente perigosas do ponto de vista da liberdade humana. Uma das manifestações prático-teóricas do normativismo acima descrito e que assemelha uma vez mais o positivismo jurídico de Kelsen com o funcionalismo penal sistêmico reside no conceito de pessoa adotado pelos autores.

\subsection{2 - Conceito de pessoa e suas consequências}

Outro aspecto que aproxima os pensamentos de Hans Kelsen, Niklas Luhmann e Günther Jakobs é o conceito de pessoa por eles desenvolvido e suas possíveis consequências no plano concreto. As bases teóricas distintas uma vez mais não foram capazes de impedir o resultado semelhante das proposições quanto ao conceito de pessoa em seu ponto de chegada.

$\mathrm{Na}$ teoria pura do direito de Kelsen o conceito de pessoa é normativamente definido como um complexo de deveres jurídicos e direitos subjetivos cuja unidade é personificada no sujeito $^{326}$. O conceito de pessoa é, portanto, artificialmente definido pela ciência jurídica e se equipara a um complexo de direito e deveres, não se confundindo com o indivíduo existente no mundo, com a pessoa natural tal qual se apresenta concretamente na vida, de maneira que no normativismo kelseniano, toda pessoa é, antes de tudo, uma pessoa jurídica $^{327}$.

\footnotetext{
${ }^{325}$ PORTILLA CONTRERAS, Guillermo. Los excesos del formalismo jurídico neofuncionalista en el normativismo del Derecho penal, cit., p. 61.

${ }^{326}$ KELSEN, Hans. Teoria pura do direito, cit., p. 193.

327 "A chamada pessoa física não é, portanto, um indivíduo, mas a unidade personificada das normas jurídicas que obrigam e conferem poderes a um e mesmo indivíduo. Não é uma realidade natural, mas uma construção jurídica criada pela ciência do Direito, um conceito auxiliar na descrição de fatos juridicamente relevantes. Neste sentido, a chamada pessoa física é uma pessoa jurídica (juristische Person)". ibidem., p. 194.
} 
Assim, a pessoa é definida de acordo com os atributos exigidos juridicamente para tanto, de maneira que pode não ser o indivíduo em si a exigência do direito, "pode não ser este o portador em questão, mas algo que o indivíduo possua e que as comunidades a que nos referimos como pessoas jurídicas igualmente possuam" ${ }^{\text {}} 28$, de acordo com o direito vigente. A pessoa em Kelsen, portanto, é desumanizada para ser formalmente constituída pela ciência jurídica.

Como se pode depreender da lógica acima exposta, o direito pode retirar de determinados indivíduos a condição de pessoas a depender da conformação que preveja para tanto e, como consequência, conferir juridicidade a situações abjetas como, por exemplo, a escravidão, uma vez que naquele regime jurídico o escravo não é juridicamente considerado pessoa. Por mais de uma vez o positivista austríaco enfrentou diretamente essa questão sem deixar margem a dúvidas: se o direito não confere aos escravos a condição de pessoas, "os escravos não são pessoas, não têm personalidade jurídica" 329 ; "que um escravo não seja juridicamente uma pessoa, que não tenha personalidade jurídica alguma, significa que não existem quaisquer normas qualificando qualquer conduta desse indivíduo como um dever ou um direito" ${ }^{330}$.

As consequências práticas da normativização do conceito de pessoa encerram uma desarmonia com as exigências de proteção e concretização dos direitos humanos ${ }^{331}$, uma vez que a ciência jurídica fica à mercê de qualquer regime político que se imponha e acaba se constituindo em possível instrumento de opressão daqueles excluídos da condição de pessoa pela ordem estabelecida.

Já a situação da pessoa na sociologia sistêmica de Niklas Luhmann assume aspectos diversos, mas não menos importantes. Na teoria luhmanniana, a sociedade não é composta de indivíduos, mas de estruturas nas quais os indivíduos são desconectados, de maneira que o funcionamento geral da sociedade independe das relações intersubjetivas e se concretiza de modo diverso das relações entre as pessoas. Não são os indivíduos que compõem a sociedade, mas sim os sistemas sociais, que possuem racionalidade interna e lógica particular.

\footnotetext{
${ }^{328}$ KELSEN, Hans. Teoria pura do direito, cit., p. 192.

329 idem.

${ }^{330}$ KELSEN, Hans. Teoria geral do direito e do estado. Trad. Luís Carlos Borges. 4. ed. São Paulo: Martins Fonte, 2005, p. 138.

${ }^{331}$ Nesse sentido, cf. JOSÉ, Caio Jesus Granduque. A construção existencial dos direitos humanos, cit., p. 119.
} 
O indivíduo só tem relevância na sociologia de Luhmann na medida em que participa do processo comunicativo que é realizado no sistema social. O indivíduo como ser biológico existente no mundo é externo à sociedade, fica no seu entorno, e sua relevância fica condicionada à participação no processo comunicativo. A chamada sociedade sem homens, base sociológica da construção de um novo sistema de direito penal possibilitou a elaboração de uma proposição deveras polêmica no penalismo contemporâneo.

Com efeito, Günther Jakobs também compreende o papel do sujeito no processo de comunicação da sociedade, mas deixa claro que nem todo ser humano pode ser considerado uma pessoa para fins penais. Para que um indivíduo seja reconhecido como pessoa é imperioso que tenha o apoio cognitivo necessário para se orientar como um destinatário da comunicação social da qual o direito é parte integrante. Entende o penalista alemão que há pessoas que com seu comportamento não prestam a garantia cognitiva mínima imprescindível para serem tratadas como pessoas, e quando tal situação se verifica, ou seja, quando um indivíduo demonstra com suas condutas que no futuro não se poderá confiar que cumprirá as normas, ele deixa de ser tratado como pessoa e passa a ser considerado um indivíduo perigoso, cujo tratamento já não é o de uma pessoa, mas de um inimigo.

A despersonalização do sujeito a quem se atribui a falta de confiança na expectativa comportamental ocorre para fins penais e se qualifica como um verdadeiro retorno ao perigosismo da criminologia positivista. A partir desta divisão entre pessoas e não pessoas (ou inimigos) no âmbito do direito penal se produz um regime de exceção para os últimos, o chamado direito penal do inimigo.

Constitui-se, desta forma, uma divisão entre o direito penal da pessoa ou cidadão e o direito penal do inimigo, a não-pessoa. No primeiro modelo de direito penal fica garantida a aplicação do ordenamento penal com todas as garantias historicamente reconhecidas, enquanto no direito penal do inimigo instaura-se um regime de exceção, de guerra ao inimigo, sem a aplicação das regras penais ordinárias.

Com efeito, os conceitos normativos de pessoa que encerram sua despersonalização não possuem outro papel objetivo senão o de legitimar regimes de exceção com consequências práticas na vida das não-pessoas, em regra, repletas de dor e sofrimento. Tais construções deixam transparecer o nível de conservadorismo de seus teóricos, incompatíveis com quaisquer projetos de defesa da pessoa humana. 
A abstração, o formalismo e a ausência de referenciais externos ao direito são características comuns ao funcionalismo penal sistêmico e ao positivismo normativista de Hans Kelsen, os quais transformam o discurso sobre a pena e o direito penal em mecanismo de legitimação da ordem social estabelecida, bem como possibilitam a construção de modelos teóricos artificiais, como o modelo de pessoa, para que o direito seja sempre a água suja, turbulenta e corrente, jamais o dique de contenção ${ }^{332}$ do poder punitivo do Estado.

\section{3 - Bases para uma análise crítica do direito}

Após a análise crítica das bases sociológicas e jurídico-filosóficas do pensamento de Günther Jakobs, cumpre estabelecer os alicerces que sustentam a análise crítica do direito penal e possibilitam o enfrentamento da teoria da prevenção geral positiva. Trata-se do referencial de teoria crítica estabelecido por Max Horkheimer e a consequente análise da sociedade e do direito a partir das estruturas sociais e relações de $\operatorname{poder}^{333}$.

No início da década de 1920 um grupo de jovens intelectuais de diferentes áreas do saber uniram-se na cidade alemã de Frankfurt am Main para empreender uma radical crítica da sociedade de seu tempo. Por iniciativa dos economistas Felix Weil e Friedrich Pollock e do filósofo Max Horkheimer, funda-se em 1923 o Institut für Sozialforschung (Instituto de Pesquisa Social), associado à Universidade de Frankfurt, recém fundada em $1914^{334}$.

${ }^{332}$ A metáfora encontra-se em ZAFFARONI, Eugenio Raúl; BATISTA, Nilo; ALAGIA, Alejandro; SLOKAR, Alejandro. Direito Penal Brasileiro II. Rio de Janeiro: Revan, 2010, p. 20.

${ }^{333}$ No seio da Escola de Frankfurt, Otto Kirchheimer publicou em 1939, em conjunto com Georg Rusche, a obra Punição e Estrutura Social, que influenciou diretamente na construção da criminologia crítica a partir da análise elaborada sobre a origem das prisões, forma burguesa de punição na passagem ao sistema capitalista. Cf. RUSCHE, Georg; KIRCHHEIMER, Otto. Punição e estrutura social. 2. ed. Rio de Janeiro: Revan, 2004.

${ }^{334}$ No Instituto de Pesquisa Social se reuniram pesquisadores de distintos campos do conhecimento para um trabalho interdisciplinar: da economia, além do citado Friedrich Pollock, participaram Henryk Grossmann e Arkadij Gurland, da crítica da cultura Theodor W. Adorno, Leo Löwenthal e Walter Benjamin, da psicologia e psicanálise Erich Fromm, do direito e da ciência política Otto Kirchheimer e Franz Neumann, além do campo da filosofia representado por Herbert Marcuse e pelo próprio Max Horkheimer. Sobre as origens do Instituto de Pesquisa Social, v. NOBRE, Marcos. A Teoria Crítica. 2. ed. Rio de Janeiro: Jorge Zahar Ed., 
A pesquisa interdisciplinar do Instituto teve como fonte de referência comum a obra de Karl Marx, que ditou a unidade necessária para as investigações, motivo pelo qual a experiência ficou conhecida como materialismo interdisciplinar. ${ }^{335}$

A Teoria Crítica edifica-se no plano das pesquisas da chamada Escola de Frankfurt $^{336}$, e ganha o sentido que hoje a caracteriza a partir do texto de Max Horkheimer denominado "Teoria Tradicional e Teoria Crítica”, publicado originalmente em 1937 na Zeitschrift für Sozialforschung (Revista de Pesquisa Social), publicação oficial do Instituto de Pesquisa Social ${ }^{337}$.

A concepção tradicional de teoria foi edificada como um conjunto de proposições abstratas acerca de um campo de objetos a partir das quais, segundo uma relação causal, podem ser formuladas regras gerais pare explicar o liame entre os fenômenos naturais ${ }^{338}$. Nesta concepção teórica, a tarefa do cientista é estabelecer conexões objetivas entre os dados que observa e formular hipóteses, de modo a possibilitar a previsão dos acontecimentos diante das mesma condições observadas.

A observância das relações causais dos fenômenos objetos de estudo é despida de valoração por parte do teórico, que não intervém nesse processo de descrição da realidade e atua de modo a abstrair dos objetos os sentidos e as qualidades que poderiam ser atribuídos pelo cientista a partir de sua observação. O pesquisador, portanto, é um mero observador dos fenômenos que descreve a partir de relações objetivas de causa e efeito.

A tradição do conhecimento científico das ciências naturais é recepcionada nas ciências sociais com a aceitação dessa pretensa neutralidade do teórico. Como no âmbito das ciências humanas o sujeito é igualmente objeto da investigação, pois a pesquisa da sociedade requer o estudo das condutas humanas que a constitui, o teórico precisaria abster-se de qualquer valoração dos fenômenos estudados, sob pena de sua investigação constituir uma mera confirmação de seus valores pessoais ${ }^{339}$.

2008, p. 12 e ss.; MATOS, Olgária C. F.. A Escola de Frankfurt: luzes e sombras do Iluminismo. São Paulo: Moderna, 1993, p. 12 e ss.

${ }^{335}$ NOBRE, Marcos. A Teoria Crítica, cit., p. 15.

${ }^{336}$ Criticamente quanto a esta nomenclatura, cf. Ibidem, p. 16 e ss.

${ }^{337}$ HORKHEIMER, Max. Teoría Tradicional y Teoría Crítica, cit., passim.

338 ibidem, p. 223.

${ }^{339}$ NOBRE, Marcos, op. cit., p. 37. 
A concepção tradicional de teoria pressupõe um rigoroso isolamento entre a tarefa de conhecer e a de agir, ou seja, edifica um aporte teórico sem objetivos práticos, sem qualquer pretensão transformadora da realidade que estuda e se limita a descrever os fenômenos.

Todavia, ao contrário do que propõe, ao esquivar-se de qualquer valoração na descrição das relações sociais, a teoria tradicional mostra-se, em verdade, parcial, uma vez que ignora os elementos históricos, sociais e políticos dos fenômenos que pesquisa. Conforme aponta Marcos Nobre "em nome de uma pretensa neutralidade da descrição, a Teoria Tradicional resigna-se à forma histórica presente da dominação"340.

Além de parcialidade que a caracteriza, a Teoria Tradicional tampouco é capaz de conhecer os fenômenos que estuda, ante a ignorância do elemento histórico no qual seu objeto de estudo está necessariamente inserido. Assim, esse modelo de teoria permanece em uma análise superficial dos fenômenos, sendo capaz de construir apenas um conjunto teórico cientificamente limitado, insuficiente e, não raro, equivocado e enviesado em prol de uma ordem estabelecida.

Portanto, a Teoria Tradicional não consegue cumprir os desígnios a que se propõe, sendo parcial e limitada, incapaz de compreender a realidade social como um todo, traduzindo um conhecimento da sociedade que não passa do nível da aparência, da superfície dos fenômenos.

Por sua vez, a concepção crítica de teoria formulado por Max Horkheimer pressupõe um efeito prático no mundo: a transformação social das formas de dominação que impedem o pleno exercício da liberdade e da igualdade. Para tanto não separa o conhecimento da ação de forma rígida como faz a teoria tradicional, senão que as considera conjuntamente. A teoria crítica analisa o existente com vistas à sua transformação, identificando os bloqueios que dificultam o melhor desenvolvimento da sociedade.

Assim, não se trata meramente de descrever as coisas como são, mas de identificar nessa realidade as possibilidades de sua transformação. É parte também do conhecimento essa identificação das barreiras à transformação, de modo que se torna parcial a teoria que se limita a descrever a realidade, na medida em que não conhece o todo.

\footnotetext{
${ }^{340}$ NOBRE, Marcos. A Teoria Crítica, cit., p. 38.
} 
A primeira tarefa do teórico crítico é realizar um diagnóstico do tempo presente, situar-se historicamente e compreender de forma ampla a realidade concreta, pois somente a partir daí pode apontar para o desenvolvimento histórico dessa realidade social. Assim, teoria e prática passam a fazer parte de um mesmo momento na pesquisa dos fenômenos sociais.

A inspiração para essa construção vem da clássica afirmação de Karl Marx: “os filósofos apenas interpretaram o mundo de diferentes maneiras; o que importa é transformá-lo." 341

A teoria crítica possui dois princípios fundamentais: a orientação para a emancipação e o comportamento crítico ${ }^{342}$. O primeiro princípio alerta para o fato de que não basta a descrição de como a sociedade funciona, senão que deve ser feito um diagnóstico concreto à luz da emancipação das formas de opressão presentes nas relações sociais vigentes, ou seja, uma descrição concreta da realidade que aponte os obstáculos para o pleno exercício da liberdade.

O comportamento crítico, segundo princípio fundamental da concepção crítica de teoria, assinala que o conhecimento produzido na forma tradicional é parcial, pois não passa do nível da superfície, da aparência. Descarta, desta forma, descrições atemporais e neutras da sociedade, bem como rechaça modelos teóricos que partem da apresentação de modelos abstratos de sociedades sem conflitos reais.

Assim, o comportamento crítico e a orientação para a emancipação caracterizam o pensamento científico crítico, sempre voltado para o porvir, para a transformação das situações sociais de injustiça.

Descritas as bases de uma abordagem teórica que se pretende crítica, cumpre descrever de que forma a teoria social e o direito devem ser abordados conforme tal perspectiva, o que revela uma direta contraposição às referências utilizadas para a elaboração da teoria da prevenção geral positiva, objeto do presente trabalho.

A perspectiva crítico-dialética abandona radicalmente o perfil de análise social funcionalista isenta de valores, meramente especulativa, também comum na análise do

\footnotetext{
${ }^{341} \mathrm{O}$ escrito conhecido como Teses sobre Feuerbach encontra-se publicado em MARX, Karl; ENGELS, Friedrich. A ideologia alemã. Trad. Rubens Enderle et al. São Paulo: Boitempo, 2007, p. 534-535.

${ }^{342}$ NOBRE, Marcos. A Teoria Crítica, cit., p.32-33.
} 
direito positivista ${ }^{343}$, para apresentar um conjunto teórico comprometido em impulsionar a transformação da realidade social objeto de estudo. Para tanto, o estudo da sociedade é levado a cabo pela análise dialética das contradições sociais e pela compreensão dos mecanismos de dominação entre os grupos que formam o tecido social.

Ao contrário do modelo harmônico e idealista de sociedade próprio do funcionalismo, a compreensão crítica da sociedade demanda o reconhecimento dos conflitos a ela inerentes a partir de sua divisão entre grupos com interesses distintos e contrapostos. Ao arquétipo sistêmico e coeso de sociedade se contrapõe um conjunto assimétrico e conflitivo, característico da sociedade inserida no modo de produção capitalista, cujo núcleo estrutural básico é concebido como expressão de interesses diferenciados e antagônicos das classes sociais ${ }^{344}$.

Ao lado do reconhecimento da estrutura social conflitiva, também é característica do conhecimento crítico-dialético a historicidade das referidas características, de maneira que o estudo da sociedade deve ser dirigido igualmente à superação do referido modelo, uma vez que inegavelmente injusto. Não se trata de mera descrição da realidade existente, senão que o teórico deve igualmente apontar para as possibilidades de transformação das estruturas sociais.

No campo do direito, o empreendimento de um estudo crítico a partir do conflito e das relações de poder na sociedade ganhou força principalmente a partir do final dos anos $1960^{345}$, quando começaram a ser projetadas investigações e análises sociopolíticas e interdisciplinares do fenômeno jurídico ${ }^{346}$. A manifestação do direito na realidade concreta, sua relação com o poder e com a ideologia, a contestação do tipo de justiça desenvolvido em cada espaço, enfim, um estudo do direito para além do conjunto de normas tornou possível não só expor as deficiências do modelo positivista imperante,

\footnotetext{
${ }^{343}$ Nesse sentido é a crítica de Alysson Leandro Mascaro: “O jurista, ao construir um mundo à parte, formalista e legalista, incorre nesse risco: explica os fatos de maneira fantasiosa, e recorre a ferramentas que só estão no seu pensamento - como os conceitos de validade, legitimidade, democracia, bem comum - mas estão longe da realidade. O jurista em geral especula cerebrinamente em torno de coisas não-dialéticas: paz social, bem comum, a ordem, a justiça tributária, a legitimidade etc., como se fossem dados constantes em qualquer sociedade, como se fossem marcos inabaláveis. Trata-se mais de uma pregação que, propriamente, de um entendimento profundo da sociedade." Lições de Sociologia do Direito, cit., p. 103.

${ }^{344}$ ALVES, Alaôr Caffé. Estado e ideologia, cit., p. 94.

${ }^{345}$ Com evidentes precedentes, especialmente aqueles autores que empreenderam estudos do direito no contexto soviético, como Eugeny B. Pasukanis e Peter I. Stucka.

${ }^{346}$ Além da própria teoria crítica da Escola de Frankfurt, motivaram o desenvolvimento da teoria crítica do direito o chamado economicismo jurídico soviético, os estudos de Foucault e a releitura da teoria marxista empreendida por Gramsci e seu desenvolvimento pelo grupo de Althusser. Cf. WOLKMER, Antonio Carlos. Introdução ao pensamento jurídico crítico. 6. ed. São Paulo: Saraiva, 2008, p. 17.
} 
como também empreender uma análise mais qualificada e crítica do fenômeno jurídico tal qual se apresenta na vida social.

O saber jurídico crítico destaca-se por seu objetivo de revelar as distorções entre as prescrições normativas e as relações sociais concretas, ou seja, de distinguir, "na esfera jurídica, o 'nível das aparências' (realidade normativa) da 'realidade subjacente' (o sublinear, o que não está prescrito mas existe)"347. E tal aspiração só se torna possível com o rompimento do paradigma idealista, tecnocrático e positivista por meio de um modelo crítico que adote uma racionalidade emancipatória ${ }^{348}$.

Para tanto é preciso reconhecer que o direito não se encerra naquilo que o positivismo o define como tal, não se encerra nele mesmo. O idealismo e o formalismo característicos do paradigma dominante dão lugar a uma análise mais profunda do direito, que revele as relações de poder subjacentes ao plano normativo e o confronto com o resultado de sua manifestação na vida social concretamente considerada ${ }^{349}$.

É inegável reconhecer que o direito é um fenômeno condicionado a interesses de diversas ordens (políticos, econômicos, sociais etc.), que entram em disputa por meio dos diferentes anseios dos grupos sociais envolvidos na dinâmica social. O conteúdo ideológico do direito, reflexo dos interesses da classe dominante na sociedade ${ }^{350}$, revela-se na própria tentativa de ocultar a presença dos referidos interesses através da difusão de um paradigma que o transmite sob o prisma da neutralidade ${ }^{351}$. O desvelamento das relações

\footnotetext{
${ }^{347}$ WOLKMER, Antonio Carlos. Introdução ao pensamento jurídico crítico, cit., p. 19.

${ }^{348}$ Nesse sentido, Antonio Carlos Wolkmer conceitua a chamada "teoria juridica crítica" como "a formulação teórico-prática que se revela sob a forma do exercício reflexivo capaz de questionar e de romper com o que está disciplinarmente ordenado e oficialmente consagrado (no conhecimento, no discurso e no comportamento) em dada formação social e a possibilidade de conceber e operacionalizar outras formas diferenciadas, não repressivas e emancipadoras, de prática jurídica”. idem.

349 “As relações jurídicas, bem como as formas do Estado, não podem ser explicadas por si mesmas, nem pela chamada evolução geral do espírito humano; essas relações têm, ao contrário, suas raízes as condições materiais de existência, em suas totalidades, condições estas que Hegel, a exemplo dos ingleses e dos franceses do século 18, compreendia sob o nome de 'sociedade civil'”. MARX, Karl. Contribuição à crítica da economia política. Trad. Florestan Fernandes. 2. ed. São Paulo: Expressão Popular, 2008, p. 47.

${ }^{350}$ No mesmo sentido, Joaquín Herrera Flores apontou que "o direito é sempre um processo de criação e reprodução de objetos: normas, regras e procedimentos que estão em estreita relação com a divisão social em classes sociais hegemônicas e subordinadas." HERRERA FLORES, Joaquín. 16 premisas de una teoría crítica del derecho. In.: CORREAS, Oscar; PRONER, Carol (coord.). Teoria crítica dos direitos humanos: in memoriam Joaquín Herrera Flores. Belo Horizonte: Fórum, 2011, p. 13.

${ }^{351}$ Nesse sentido é a advertência de Antonio Alberto Machado: "Apesar de tais evidências de que o direito encerra mesmo um conteúdo axiológico, o fato é que o direito liberal burguês, na modernidade, produziu sempre um discurso tendente à ocultação dos seus aspectos valorativos. No século XX, por exemplo, a ideologia jurídica prevalecente, o normativismo positivista, logrou um espantoso êxito nessa tarefa de ocultar as dimensões políticas do direito e de sua ciência, impondo-se como a mais prestigiada maneira de conhecer
} 
de poder e suas consequentes influências na conformação do direito é tarefa fundamental para que se empreenda uma análise crítica do fenômeno jurídico.

O empreendimento de tal tarefa, todavia, não é possível a partir de uma concepção idealista ou racionalista do direito e sua análise abstrata e formalista do fenômeno jurídico com a consequente criação de uma realidade ideal sem relação com a concretude dos processos e trocas sociais. As normas não podem ter uma essência completamente diferente das relações sociais nas quais estão inseridas, de modo que seu estudo deve estar imerso na historicidade, nos processos e contradições existentes na dinâmica social.

$\mathrm{O}$ direito deve estar relacionado sempre às suas raízes no mundo, pois "o direito sem a realidade social na qual está imerso não é senão um conjunto de expressões formais abstratas sem efetivo sentido jurídico"352. Para além da consciência, o direito perfaz-se como realidade efetiva no plano social, na vida das pessoas, nos interesses que mantém, na reação social à sua aplicação e nas contradições decorrentes de todas essas possibilidades de observação do fenômeno jurídico.

A proposta de uma teoria crítica do direito consiste na construção de uma visão dinâmica e contextualizada do direito, do pensamento e da prática jurídica do seu tempo, que seja comprometida com a pauta política, ética e social que sirva de guia para a construção de uma nova racionalidade de defesa das necessidades humanas em contraposição aos interesses do capital e direcione positivamente o papel dos juristas nos momentos de afrontar o sofrimento humano ${ }^{353}$.

\section{4 - Teoria crítica e o direito penal: a crítica criminológica do direito penal}

Assim como o desenvolvimento da teoria crítica do direito, igualmente na década de 1960 as ciências criminais, especialmente a criminologia, passaram por uma significativa transformação a partir de uma mudança paradigmática da forma de

o fenômeno jurídico, de aplica-lo e transmiti-lo de modo politicamente asséptico.”. MACHADO, Antônio Alberto. Ensino jurídico e mudança social, cit., p. 16.

${ }^{352}$ ALVES, Alaôr Caffé. Dialética e direito, cit., p. 15.

${ }^{353}$ HERRERA FLORES, Joaquín. 16 premisas de una teoría crítica del derecho, p. 14-16. 
compreensão do fenômeno criminal. O modelo de compreensão da questão criminal predominante até então fundamentava-se na ideia consensual de sociedade na qual o direito penal representava a manifestação da vontade geral em torno das condutas mais graves e um meio eficaz de prevenção dos delitos. Até então não eram problematizadas de maneira central no âmbito das ciências criminais as relações de poder desta construção harmônica, nem mesmo as complexas relações de violência estrutural e institucional que advinham do funcionamento dos mecanismos de controle social punitivo ${ }^{354}$.

O paradigma de análise do fenômeno criminal até então era o etiológico de raiz positivista, que concebia o crime como um fenômeno natural e causalmente determinado, para o qual a ciência criminológica deveria encontrar a solução em defesa da sociedade. $\mathrm{O}$ remédio comumente destinado ao controle das causas do delito é a pena, instrumento de defesa social e quase incontestável diante do seu papel de controle da criminalidade, tida como uma realidade ontológica.

A análise empreendida pela criminologia de viés etiológico conferiu sustentação ideológica às ideias de "combate ao crime" por meio do sistema penal, além de influir no conceito dogmático de crime, que toma a ideia positivista de violência como aspecto individual, de modo a restarem imunizadas as relações de poder e violência produzidas pelo próprio sistema penal ${ }^{355}$.

A virada paradigmática no âmbito da criminologia deu-se com o desenvolvimento da teoria da reação social ${ }^{356}$ na sociologia do desvio estadunidense, especialmente influenciada pelo interacionismo simbólico e pela etnometodologia. O labelling approach recusou o modelo de consenso e empreendeu um estudo do fenômeno criminal a partir da reação social ao delito e das dinâmicas do processo de criminalização, passando da "realidade pré-constituída" para a "realidade construída"357.

A ideia central deste referencial teórico é que o desvio e a criminalidade não são características intrínsecas da conduta, ou seja, nega a existência do crime como conduta

\footnotetext{
${ }^{354}$ Cf. ANDRADE, Vera Regina Pereira de. Sistema penal máximo x cidadania mínima, cit., p. 37.

355 “A violência é, dessa forma, identificada com a violência individual (de uma minoria) a qual se encontra, por sua vez, no centro do conceito dogmático de crime, imunizando a relação entre a criminalidade e a violência institucional e estrutural". idem.

${ }^{356}$ Cf. CASTRO, Lola Aniyar de. Criminologia da reação social. Trad. Ester Kosovski. Rio de Janeiro: Forense, 1983.

${ }^{357}$ ZILIO, Jacson Luiz. La criminología crítica como (de) construcción del derecho penal. Revista Holística Jurídica. v. 8. Medellín: Universidad de San Buenaventura, 2010, p. 38.
} 
ontologicamente encerrada como tal. O crime, portanto, não se constitui em um fenômeno natural e independente da reação social, senão que se refere a uma conduta qualificada desta maneira. Trata-se de uma qualidade (etiqueta ou rótulo) atribuída a determinados sujeitos por meio de complexos processos de interação social ${ }^{358}$.

A partir do paradigma da reação social, não mais se admite a existência da figura do criminoso construída pela criminologia positivista, nem mesmo do crime como conduta inerentemente nociva, senão que tais qualificações são dadas por meio de complexos processos formais e informais de definição e seleção na dinâmica da vida em sociedade. A definição de determinada conduta como crime e a seleção e consequente etiquetamento de determinadas pessoas como criminosas nos processos de interação social, fizeram com que os pesquisadores críticos substituíssem o termo "criminalidade" por "criminalização", que, para além de uma mudança linguística, passou a ser mesmo o grande objeto de estudo nas ciências criminais.

A mudança do paradigma etiológico para o da reação social significou, portanto, uma radical transformação na maneira de analisar o fenômeno criminal, que ao recusar o modelo de consenso social, passou a dar maior enfoque à dinâmica dos processos de criminalização e ao papel das agências de controle social punitivo. O sistema penal caracterizado por um conjunto harmônico de normas e com o "criminoso" identificado sob parâmetros positivistas passa a dar lugar a um complexo e dinâmico processo de controle, que desvia o olhar tradicional das ciências criminais para as consequências da reação social ao delito. O objeto de estudo da criminologia, até então centrado no crime e no criminoso passa a abordar de maneira primordial o próprio sistema de justiça criminal $^{359}$ e os efeitos produzidos pela aplicação da etiqueta de criminoso aos sujeitos criminalizados por este mesmo sistema.

O verdadeiro salto qualitativo ${ }^{360}$ da passagem do paradigma etiológico para o da reação social possibilitou um posterior avanço crítico da criminologia por meio da interpretação materialista dos processos de criminalização ${ }^{361}$. Com tal enfoque analítico

\footnotetext{
${ }^{358}$ Cf. BECKER, Howard Saul. Outsiders: estudos de sociologia do desvio. Trad. Maria Luiza X. de A. Borges. Rio de Janeiro: Jorge Zahar Ed., 2008.

${ }^{359}$ ZILIO, Jacson Luiz. La criminología crítica como (de) construcción del derecho penal, cit., p. 38.

${ }^{360}$ ANDRADE, Vera Regina Pereira de. Sistema penal máximo x cidadania mínima, cit., p. 46.

${ }^{361}$ Cf. TAYLOR, Ian; WALTON, Paul; YOUNG, Jock. La nueva criminología, cit..; TAYLOR, Ian; WALTON, Paul; YOUNG, Jock (org.). Criminologia crítica. Trad. Juarez Cirino dos Santos e Sergio Tancredo. Rio de Janeiro: Edições Graal, 1980; SANTOS, Juarez Cirino dos. A criminologia radical. 3. ed. Curitiba: ICPC: Lumen Juris, 2008.
} 
foram superadas as deficiências do labeling approach no que se refere ao questionamento das estruturas sociais nas quais o sistema penal está inserido, de modo que, sem abandonar a premissa da reação social, os processos de criminalização passaram a ser analisados de maneira a considerar necessariamente as estruturas sociais, o contexto socioeconômico e as relações de poder no seio da sociedade capitalista. A corrente criminológica que complementa a dimensão da definição com a dimensão do poder na sociedade capitalista foi denominada de criminologia crítica ${ }^{362}$.

Para além do processo de definição e rotulação, a criminologia crítica avançou para o estudo das razões estruturais que sustentam esse processo numa sociedade de classes ${ }^{363}$. A partir da análise da manifestação do sistema penal na realidade concreta, dos processos dinâmicos de reação social ao delito e das relações de poder inerentes à sociedade organizada sob o modo de produção capitalista, a criminologia crítica permitiu esclarecer que, sob a pretensa e declarada neutralidade do direito penal, seu funcionamento real representa uma forma de reprodução das desigualdades, das injustiças materiais da vida social e da violência institucional ${ }^{364}$.

É a partir do desenvolvimento da criminologia da reação social e da criminologia radical que a teoria crítica encontra o direito penal e permite seu estudo sob novos parâmetros que não aqueles que até então eram utilizados sob o manto da neutralidade científica. Se a separação entre os campos de estudo da criminologia e do direito penal sempre foram relativamente destacados, a partir do desenvolvimento da criminologia crítica, esta área do saber passa a ter um papel fundamental na crítica do próprio direito

\footnotetext{
${ }^{362}$ Vera Regina Pereira de Andrade alerta que "se a utilização do paradigma da reação social é uma condição necessária, não é condição suficiente para qualificar como crítica uma Criminologia." Para a autora, a criminologia crítica, em sentido lato, é "um estágio avançado de evolução da Criminologia radical norteamericana e da nova Criminologia europeia, englobando um conjunto de obras que, desenvolvendo um pouco depois as indicações metodológicas dos teóricos do paradigma da reação social e do conflito e os resultados a que haviam chegado os criminólogos radicais e novos, chegam, por dentro desta trajetória, à superação deles. E nesta revisão crítica aderem a uma interpretação materialista - e alguns marxista, certamente não ortodoxa - dos processos de criminalização nos países do capitalismo avançado." ANDRADE, Vera Regina Pereira de. Sistema penal máximo x cidadania mínima, cit., p. 46-47.

${ }^{363}$ Cf. PAVARINI, Massimo. Control y dominación, cit., p. 163-164.

${ }^{364}$ Interessante notar que, como aponta Salo de Carvalho, "A ruptura criminológica proporcionada pela teoria do etiquetamento possibilitou inclusive a qualificação de inúmeras tendências da criminologia crítica que, ao incorporarem as ferramentas de análise dos mecanismos de criminalização primária (seletividade) e de criminalização secundária (etiquetamento/estigmatização), redirecionaram suas investigações." CARVALHO, Salo de. Ensino e aprendizado das ciências criminais no século XXI. Revista Brasileira de Ciências Criminais, v. 69. São Paulo: Editora Revista dos Tribunais, 2007, p. 273.
} 
penal, inaugurando aquilo que se convencionou denominar de crítica criminológica do direito penal ${ }^{365}$.

A crítica criminológica do direito penal ganha força especialmente no âmbito das teorias da pena, campo do direito penal que sempre foi mais relacionado com outras áreas do saber humano ${ }^{366}$. No campo da penologia, o saber crítico teve o papel fundamental de desvelar o real sentido da pena em detrimento daquele historicamente declarado, com a consequente deslegitimação das práticas punitivas em vigência, ao menos no âmbito teórico e científico.

Com efeito, o conjunto teórico formado a partir da década de 1960 edificou as bases para um pensamento crítico no âmbito das ciências criminais, de maneira a possibilitar o confronto do direito penal com a realidade concreta na qual se manifesta, a análise dos processos de reação social diante das condutas definidas como crime, além de ampliar a esfera de estudo do sistema penal tomando em consideração as relações de poder e dominação vigentes em determinada formação social.

Nessa toada, ao propugnar pela construção de uma dogmática penal crítica, Juarez Tavares assevera que a vinculação entre esta, a ordem jurídica e a ordem social não constitui mera referência acadêmica, mas o campo sobre o qual deve efetivamente se debruçar a teoria do direito penal, uma vez que não se pode conceber um conjunto teórico penal desvinculado das particularidades concretas da ordem social e dos contextos nos quais se verificam os conflitos. Neste campo de análise crítica, ao sujeito deve ser conferida centralidade na ordem jurídica e social, como pessoa e não como subsistema, de maneira que a tarefa proposta por uma dogmática crítica deva ser a demonstração da inconsistência da solução criminal, "buscando delimitar ao máximo o poder de intervenção do Estado." 367

A tarefa crítica reservada ao estudioso das ciências criminais requer, com efeito, um constante questionamento dos parâmetros de legitimidade sobre os quais se assenta a repressão penal, uma reação às tentativas de desqualificação do papel do sujeito na ordem jurídica e social, bem como a permanente apreciação dos institutos e construções jurídico-

\footnotetext{
${ }^{365}$ Cf. BARATTA, Alessandro. Criminologia crítica e crítica do direito penal, cit.; CARVALHO, Salo de. Sobre as possibilidades de uma penologia crítica: provocações criminológicas às teorias da pena na era do grande encarceramento. Revista Polis e Psique, v. 3., n. 3, 2013.

${ }^{366}$ CARVALHO, Salo de. Penas e medidas de segurança no direito penal brasileiro, cit., p. 45.

${ }^{367}$ TAVARES, Juarez. Teoria dos crimes omissivos. São Paulo: Marcial Pons, 2012, p. 273-274.
} 
penais a partir dos reais procedimentos de criminalização e do seu significado diante dos interesses políticos e dos conflitos sociais presentes ${ }^{368}$.

A partir da base teórica acima exposta, serão expostas as críticas especificamente consideradas à teoria da prevenção geral positiva cunhada por Günther Jakobs, de modo a engendrar seu confronto com os processos reais de criminalização, as consequências do seu pensamento sobre a pena no plano concreto e o papel que desempenha no plano da legitimação de práticas punitivas em sociedades cuja democracia encontra largo espaço no plano normativo.

\footnotetext{
368 "Independentemente das finalidades puramente políticas e econômicas que constituem o pano de fundo dessa atuação intervencionista, pode-se dizer que, na atualidade, o confronto entre intervenção penal e liberdade individual, que constitui o objeto final do estudo dogmático, está na dependência da forma de organização social, da definição e do papel do sujeito nessa organização e não propriamente em virtude do propalado aumento da criminalidade. Aliás, toda criminalidade não passa de uma expressão linguística, que, como se sabe, corresponde a procedimentos de criminalização, que variam conforme a época e o desenvolvimento dos interesses políticos em função dos conflitos sociais subjacentes." TAVARES, Juarez. Teoria dos crimes omissivos, cit., p. 274.
} 


\title{
CAPÍTULO 5 - CRÍTICA DA TEORIA DA PREVENÇÃO GERAL POSITIVA DE GÜNTHER JAKOBS
}

\author{
SUMÁRIO: 5. Crítica da teoria da prevenção geral positiva de Günther Jakobs - 5.1. \\ Considerações gerais - 5.2. Prevenção geral positiva e o processo de criminalização: a \\ seletividade legitimada - 5.3. Prevenção geral positiva e processo comunicativo -5.4 . \\ Prevenção geral positiva e o significado da pena: a dor como símbolo - 5.5. Prevenção \\ geral positiva e a realidade brasileira.
}

A crítica da teoria da prevenção geral positiva de Jakobs sob a ótica das ciências criminais tem como pressuposto o paradigma crítico desenvolvido no capítulo anterior. Para além das importantes críticas realizadas pela doutrina penal, cumpre confrontar a teoria da pena de Jakobs com o funcionamento do sistema penal na realidade concreta. Para tanto, a análise crítica da prevenção geral positiva passa necessariamente pelo cotejo com os processos de criminalização e a realidade brasileira.

\section{1 - Considerações gerais}

Para além das críticas às bases sociológicas e jurídico-filosóficas, que revelaram o caráter conservador da teoria da pena cunhada por Jakobs, seja pela ausência de suporte material com que constrói a prevenção geral positiva no contexto de um consenso social, seja pela normativização do conceito de pessoa, cumpre também criticar a teoria de Jakobs sob o ponto de vista das ciências criminais.

As teorias jurídicas, de maneira geral, não costumam ser elaboradas a partir de uma relação dialética com a realidade, senão que se preocupam mais com aspectos normativos e lógicos do que com a sua manifestação na concretude das relações humanas. No caso do 
direito penal não é diferente, especialmente no campo das teorias da pena, em que o seu confronto com a real incidência do poder punitivo na sociedade revelou as fragilidades e inconsistências que carregam consigo.

Jakobs, no entanto, buscou um referencial externo ao direito para fundar seu sistema de direito penal: o funcionalismo sociológico. Paradoxalmente isso serviu para permitir a construção de uma teoria da pena ainda mais fechada no plano jurídico e abstrata do ponto de vista lógico, motivo pelo qual sofreu diversas críticas igualmente no plano jurídico-penal.

O penalista alemão apresenta a teoria da prevenção geral positiva como aquela que supera as teorias da pena dominantes até então, as quais passam a ter a validade negada como tentativa de justificação legítima do poder punitivo. Contudo, a fragilidade da teoria da prevenção geral positiva de Jakobs demonstra que o objetivo não foi alcançado, pois em maior ou menor grau admite outros efeitos da pena. Nesse sentido, a teoria admite o efeito dissuasório da pena, ainda que lateral e secundário à prevenção geral positiva, além de resgatar a teoria da prevenção especial negativa na doutrina do direito penal do inimigo. Por outro lado, observa a doutrina penal a proximidade que a prevenção geral positiva de cunho sistêmico apresenta com as teorias retributivistas ${ }^{369}$, de modo a transparecer que não se trata de uma verdadeira e inovadora alternativa às tradicionais teorias da pena.

A fragilidade da teoria da pena de Jakobs também se verifica na falta de suporte empírico que a sustente e na insuficiente justificação do motivo pelo qual os mesmos efeitos desejados pela prevenção geral positiva não poderiam ser alcançados com meios menos gravosos do que a pena ${ }^{370}$.

Outra crítica importante à teoria da pena de Jakobs consiste na utilização do ser humano como meio para alcançar fins que, em essência, são absolutamente simbólicos ${ }^{371}$, na tentativa de integrar e garantir a estabilidade de sociedades plurais nas quais não há a alegada uniformidade normativa, tampouco homogeneidade cognitiva ${ }^{372}$.

\footnotetext{
${ }^{369}$ Cf. BECHARA, Ana Elisa Liberatore Silva. Bem jurídico-penal, cit., p. 297; BUSATO, Paulo César. Direito penal, cit., p. 788.

${ }^{370}$ Nesse sentido, Jesús Maria Silva Sánchez questiona a legitimidade de utilização de um meio estigmatizante para alcançar a integração social. Cf. SILVA SÁNCHEZ, Jesús Maria. Aproximación al Derecho Penal contemporâneo. 2. ed. Buenos Aires: B de F, 2010, p. 375.

${ }^{371}$ Cf. ZAFFARONI, Eugenio Raúl; BATISTA, Nilo; ALAGIA, Alejandro; SLOKAR, Alejandro. Direito Penal Brasileiro I. Rio de Janeiro: Revan, 2003, p. 123; DIETER, Maurício Stegemann. A política criminal atuarial: a Criminologia do fim da história. Rio de Janeiro: Revan, 2013, p. 99.

${ }^{372}$ MADRID, Antonio. La política y la justicia del sufrimiento. Madrid: Trotta, 2010, p. 182.
} 
Diante de tais características, a doutrina penal não hesita em concluir que a teoria da prevenção geral positiva de Jakobs representa um aporte de incremento da atuação do sistema penal notadamente autoritário ${ }^{373}$, cujo potencial de esvaziamento das garantias penais clássicas ${ }^{374}$ ataca frontalmente formações sociais de índole democrática.

A despeito da validade das críticas acima expostas, resta necessária, ainda, a crítica da prevenção geral positiva a partir do seu confronto com a realidade concreta. O cotejo da teoria da pena de Jakobs com o real funcionamento do processo de criminalização e com as características materiais da pena possibilitam uma análise das consequências de sua defesa em um ambiente com características culturais e sócio-políticas diversas daquela em que foi originalmente forjada.

\section{2 - Prevenção geral positiva e o processo de criminalização: a seletividade legitimada}

Embora Jakobs construa a teoria da prevenção geral positiva consciente de que não é possível a atuação do direito penal em todos os casos, o autor não deixa clara a consequência social da incidência do direito penal na garantia da vigência da norma. A pretensa neutralidade do sistema de direito penal elaborado pelo autor não apenas passa ao largo do significado da proteção da norma às custas de alguns responsáveis, como tem a lógica consequência de, por isso mesmo, legitimar referido estado de coisas.

O funcionamento do sistema penal em Jakobs, como na maioria dos penalistas, deriva de um pressuposto igualitário de criminalização e funcionamento das instituições e agências do sistema penal. Se não há efetiva criminalização de todos os atos tidos por criminosos, tal dado se extrai da incapacidade operacional do sistema penal, mas quando este sistema realmente atua, não há qualquer consideração sobre sua forma desigual de atuação concreta, mantendo-se, assim, o reino da neutralidade, característica da filosofia jurídica positivista.

\footnotetext{
${ }^{373}$ BECHARA, Ana Elisa Liberatore Silva. Bem jurídico-penal, cit., p. 297.

${ }^{374}$ SILVA SÁNCHEZ, Jesús Maria. Aproximación al Derecho Penal contemporâneo, cit., p. 379-380.
} 
Com efeito, a teoria da prevenção geral positiva elaborada pelo autor alemão confia em uma atuação neutra e objetiva do sistema penal para que possa ser garantida a vigência da norma e a estabilidade social. Todavia, ignora que a manutenção da coesão social pela garantia das expectativas normativas se dá às custas de uma determinada parcela da sociedade e pela punição levada a efeito a partir da prática de um reduzidíssimo conjunto de fatos criminalizados. Na medida em que ignora o real funcionamento do sistema penal, a teoria da prevenção geral positiva não só referenda tais práticas, como perde sustentação no plano científico.

A seletividade penal foi revelada de maneira sólida a partir dos estudos desenvolvidos pela criminologia da reação social e crítica ${ }^{375}$, uma vez que somente após a virada paradigmática o olhar criminológico passou a analisar o sistema penal pelo viés da reação social e pelas relações de poder a ele inerentes. A seletividade como elemento estrutural do funcionamento do processo de criminalização foi uma das revelações fundamentais para uma análise crítica do sistema penal e, especialmente, das teorias da pena.

As ideias que estão na base das principais construções dogmáticas do direito penal e até mesmo do senso comum sobre o processo de criminalização ora resgatam os conceitos construídos no positivismo criminológico sobre a criminalidade como um atributo de uma minoria de indivíduos perigosos, ora partem de uma ingênua e igualmente equivocada concepção que considera a atuação do direito penal de maneira isonômica. Esta última concepção acaba por justificar a ideia de que os criminalizados são representantes de setores sociais marginalizados pelo fato de que essas pessoas cometem mais crimes que as demais, ou seja, defendem a ideia da pobreza como um fator gerador da criminalidade, quando, em verdade, é um fator determinante da criminalização ${ }^{376}$.

Os estudos criminológicos levados a efeito sobre os processos de criminalização e as estatísticas criminais revelaram que estas representam apenas uma ínfima parcela do que significa a criminalidade real. Para além da existência de uma larga cifra oculta representada pela diferença entre a criminalidade real e aquela oficialmente registrada, chegou-se também à conclusão de que a prática delitiva se manifesta em todos os estratos

\footnotetext{
${ }^{375}$ Cf. ANDRADE, Vera Regina Pereira de. Sistema penal máximo x cidadania mínima, cit., p. 49.

${ }^{376}$ Cf. ZAFFARONI, Eugenio Raúl; BATISTA, Nilo; ALAGIA, Alejandro; SLOKAR, Alejandro. Direito Penal Brasileiro I, cit., p. 46.
} 
sociais, muito embora somente os grupos sociais mais vulneráveis sejam objeto de concreta criminalização.

A seletividade penal revela-se tanto pela incapacidade estrutural das agências do sistema penal operacionalizarem toda a programação da lei penal (criminalização primária), como pelo fato de que a criminalização secundária se efetiva sobre pessoas que possuem algumas características pessoais e diante de determinados comportamentos realizados por estas mesmas pessoas. A distribuição desigual do aparelho punitivo estatal revela a faceta autoritária desse mecanismo de controle social que conduz à reprodução das condições de desigualdade sobre a qual ele mesmo opera.

Segundo a lição de Eugenio Raúl Zaffaroni, Nilo Batista, Alejandro Alagia e Alejandro Slokar, "todas as sociedades contemporâneas que institucionalizam ou formalizam o poder (estado) selecionam um reduzido número de pessoas que submetem à sua coação com o fim de impor-lhes uma pena" ${ }^{\text {377 }}$. O processo de criminalização é justamente essa seleção penalizante levada a cabo pelo Estado, que se processa em etapas distintas e com características próprias.

A primeira etapa da criminalização (criminalização primária) é aquela desempenhada na esfera legislativa na eleição das condutas que serão classificadas como criminosas e passíveis de persecução penal. A escolha das condutas puníveis representa as opções político-criminais, sendo especialmente influenciada pelos setores sociais mais influentes política e economicamente, ao contrário da neutra e objetiva ideia defendida por Jakobs do mero reconhecimento nas normas penais dos valores determinantes da identidade da sociedade segundo um consenso.

Já na primeira fase do processo de criminalização a teoria da prevenção geral positiva de Jakobs não resiste ao fato de que é uma identidade de classe e não a identidade da sociedade em si o que se pretende proteger através da intervenção do sistema penal.

A criminalização primária constitui um programa que depende do funcionamento de outras agências penais para sua realização. A criminalização secundária, por sua vez, é precisamente a realização do programa formalmente previsto em ações punitivas sobre pessoas concretamente consideradas ${ }^{378}$ por meio do trabalho de policiais, promotores e

\footnotetext{
${ }^{377}$ ZAFFARONI, Eugenio Raúl; BATISTA, Nilo; ALAGIA, Alejandro; SLOKAR, Alejandro. Direito Penal Brasileiro I, cit., p. 43.

378 idem.
} 
juízes, por exemplo. É o momento em que aquele programa definido pelo legislador se realiza, de modo a efetuar concretamente a persecução penal sobre determinado indivíduo que teria praticado alguma conduta primariamente criminalizada.

Uma das premissas fundamentais do processo de criminalização é a incapacidade estrutural de realização prática de todo o programa de criminalização primária, ou seja, há em todo sistema penal uma grande diferença entre aqueles fatos puníveis praticados na sociedade e os efetivamente criminalizados pelas agências do sistema penal. A seletividade é, em verdade, uma característica estrutural do direito penal, muito embora o grau de seletividade possa variar de acordo com as características de cada sociedade e por circunstâncias conjunturais específicas e variáveis, sendo efetivamente mais elevada em sociedade estratificadas ${ }^{379}$ como a brasileira.

Em certo sentido é natural que a seletividade se verifique, pois é inimaginável que se cumpra todo o programa primário de criminalização, o que converteria a sociedade em um caos em busca da concretização de um programa inexequível ${ }^{380}$. A atuação seletiva, por ser estrutural, se constitui em um imperativo de atuação do sistema penal, de maneira que o problema central reside na forma como essa seletividade se manifesta na prática dos processos reais de criminalização.

As limitações operativas das agências do sistema penal (notadamente as corporações policiais) fazem com que a regra da criminalização secundária seja a seleção de pessoas que pratiquem fatos grosseiros de fácil detecção - a obra tosca da criminalidade - e que por sua incapacidade de acesso ao poder político, econômico ou midiático causem menos problemas às referidas agências ${ }^{381}$. Esta seleção de pessoas criminalizadas é a responsável pela formação estereótipo do criminoso $^{382}$, uma vez que a divulgação acrítica desses fatos como se não fossem fruto de uma seleção dentre tantos outros fatos

\footnotetext{
${ }^{379}$ ZAFFARONI, Eugenio Raúl; BATISTA, Nilo; ALAGIA, Alejandro; SLOKAR, Alejandro. Direito Penal Brasileiro I, cit., p. 45 e 50.

380 “A criminalização primária é um programa tão imenso que nunca e em nenhum país se pretendeu leva-lo a cabo em toda a sua extensão nem sequer em parcela considerável, porque é inimaginável. (...) Embora ninguém possa conceber seriamente que todas as relações sociais se subordinem a um programa de criminalização faraônico (que paralisasse a vida social e convertesse a sociedade em um caos na busca da realização de um programa irrealizável), a muito limitada capacidade operativa das agências de criminalização secundária não tem outro recurso senão proceder sempre de modo seletivo.” ibidem, p. $43-44$. 381 ibidem, p. 46.

${ }^{382}$ Sobre o estigma, cf. GOFFMAN, Erving. Estigma: notas sobre a manipulação da identidade deteriorada. 4. ed. Rio de Janeiro: LTC, 2008.
} 
criminosos cometidos gera a "imagem pública do delinquente com componentes de classe social, étnicos, etários, de gênero e estéticos"383.

Assim, a obra tosca da criminalidade e a imagem pública do delinquente passam a configurar os principais fatores da criminalização secundária ou de vulnerabilidade perante o poder punitivo, principalmente em sociedades com profundas diferenças sociais, étnicas e estéticas como a brasileira. A orientação seletiva das agências penais no momento da criminalização secundária baseia-se, portanto, na vulnerabilidade concreta que as pessoas apresentam diante do caráter operacional limitado das mesmas agências.

Nesse contexto, os autores classificam a criminalização secundária em três formas: criminalização conforme o estereótipo, criminalização por comportamento grotesco ou trágico e criminalização devida à falta de cobertura. A primeira forma de criminalização, que constitui a regra em virtude da maior vulnerabilidade, é aquela que se efetua sobre pessoas que se enquadram no estereótipo criminal e praticam a obra tosca da criminalidade. Já com menor frequência, a criminalização por comportamento trágico se dá sobre pessoas que, a despeito de não se enquadrarem no estereótipo, praticam atos de tamanha brutalidade que se tornam vulneráveis à criminalização. Por fim, e de modo mais raro, a criminalização por falta de cobertura ocorre quando uma pessoa que em princípio é invulnerável ao poder punitivo perde uma disputa de poder e, com isso, sofre uma ruptura na vulnerabilidade ante o poder punitivo. ${ }^{384}$

O direito penal não atua de forma linear e uniforme com relação a todo tipo de conduta que se propõe a prevenir. Pelo contrário, a seleção levada a cabo no processo de criminalização secundária conforme o estereótipo torna inoperante o seu funcionamento para outros grupos sociais ${ }^{385}$ que não aqueles que são preferencial e estruturalmente alvos das agências penais. Esse processo estrutural culmina, portanto, na criminalização concreta como regra geral de um grupo social específico que carrega consigo as características do estereótipo criminoso.

No caso brasileiro, o funcionamento do sistema penal traduz-se em uma seleção de pessoas que carregam consigo características sociais, etárias, raciais, estéticas e de gênero

\footnotetext{
${ }^{383}$ ZAFFARONI, Eugenio Raúl; BATISTA, Nilo; ALAGIA, Alejandro; SLOKAR, Alejandro. Direito Penal Brasileiro I, cit., p. 45.

${ }^{384}$ ibidem, p. 49.

${ }^{385}$ ibidem, p. 46-47.
} 
específicas $^{386}$ que transformam o processo de criminalização brasileiro em um processo de criminalização da pobreza ${ }^{387}$, com consequências verdadeiramente destrutivas da dignidade e da própria vida humana ${ }^{388}$.

O confronto da teoria da prevenção geral positiva com a realidade do processo de criminalização desvela o caráter ideológico de seus pressupostos. Se para Jakobs a norma penal é a representação da identidade da sociedade a ser protegida pela pena, tal assertiva cai por terra a partir do real processo de elaboração das normas penais, que ao invés de representarem a normatização de um consenso social diante dos valores mais importantes da vida em sociedade, reproduzem a escolha de interesses dos atores e grupos sociais envolvidos nas disputas de poder no processo legislativo.

Além disso, a preservação da identidade da sociedade pela reafirmação da norma não resiste ao fato de que, a despeito da prática de muitas das condutas definidas como crimes, somente uma pequena parte delas é realmente objeto de imposição de pena, ou seja, pretende-se a manutenção da ordem social com a reafirmação de apenas um conjunto ínfimo de normas penais, ainda que a maioria delas seja efetivamente violada no plano da vida social real ${ }^{389}$.

Demais disso, a criminalização secundária revela o caráter autoritário que se atribui à pena pela teoria da prevenção geral positiva com a reafirmação da vigência da norma por meio da punição de apenas algumas pessoas especialmente determinadas no conjunto da sociedade, de modo a ocultar sob o manto da manutenção da ordem social a arbitrária utilização da pena como forma de controle social da pobreza. A teoria da prevenção geral

\footnotetext{
${ }^{386}$ Cf. BECHARA, Ana Elisa Liberatores Silva; CACICEDO, Patrick. Sobre la situación carcelária en Brasil. Observaciones críticas. Revista General de Derecho Penal, v. 18, 2012.

${ }^{387} \mathrm{O}$ que, ressalte-se, não possui caráter conspiratório ou determinado, mas representa o próprio resultado do funcionamento estrutural do sistema punitivo. "As agências de criminalização secundária não operam seletivamente sobre os vulneráveis porque alguma coisa ou alguém maneja todo o sistema penal de modo harmônico. Esta concepção conspiratória é falaciosa e tranquilizadora, porque identifica sempre um falso inimigo e desemboca na criação de um novo bode expiatório (classe, setor hegemônico, partido oficial, grupo econômico, quando não grupos religiosos ou étnicos)." ZAFFARONI, Eugenio Raúl; BATISTA, Nilo; ALAGIA, Alejandro; SLOKAR, Alejandro. Direito Penal Brasileiro I, cit., p. 48.

${ }^{388}$ A seletividade do sistema penal não se afigura presente apenas no aspecto da criminalização, mas também na seleção de vítimas e policiais, que se engendra nos mesmos estratos sociais dos criminalizados, ocasionando o perverso efeito descrito magistralmente na seguinte passagem de Eugenio Raúl Zaffaroni, Nilo Batista, Alejandro Alagia e Alejandro Slokar: "Se considerarmos que os criminalizados, os vitimizados e os policizados (ou seja, todos aqueles que sofrem as consequências desta suposta guerra) são selecionados nos estratos sociais inferiores, cabe reconhecer que o exercício do poder estimula e reproduz antagonismos entre as pessoas desses estratos mais frágeis, induzidas, a rigor, a uma auto-destruição." ibidem, p. 58.

${ }^{389}$ Para uma análise crítica da prevenção geral positiva como forma de legitimação da seletividade penal, cf. QUEIROZ, Paulo. Direito penal, cit., p. 97.
} 
positiva não resiste ao fato de que não é legítima a tentativa de manutenção da ordem social com a reafirmação de apenas algumas normas através da punição de um mesmo conjunto de pessoas socialmente determinado.

A ordem que se mantém efetivamente por meio da incidência do poder punitivo é, com efeito, a ordem vigente em determinada sociedade. No caso brasileiro, a ordem social a ser mantida pela incidência do sistema punitivo é aquela historicamente marcada pela injustiça e níveis escandalosos de desigualdade social ${ }^{390}$. A manutenção da ordem social por meio de um mecanismo que reproduz as desigualdades da ordem que se pretende manter revela o potencial autoritário do discurso punitivo do funcionalismo sistêmico, cuja legitimidade resta negada sob a ótica de qualquer discurso cujo norte seja a emancipação humana e a promoção da liberdade.

\section{3 - Prevenção geral positiva e processo comunicativo}

A relação comunicativa da pena no processo de interação social do qual parte Jakobs para a elaboração de sua teoria fundamentadora do poder punitivo é de capital importância tanto para compreensão do sentido da pena, quanto para as suas consequências político-criminais. Segundo a teoria da prevenção geral positiva, a pena tem a função de estabilização social com a reafirmação da norma violada pelo infrator e o consequente desequilíbrio causado por essa conduta. A pena tem, portanto, o efeito simbólico de gerar, através do processo de comunicação de seu significado social, o sentimento de confiança nas normas em todos os indivíduos a estas submetidos através do processo de comunicação de seu significado social.

Nas sociedades contemporâneas caracterizadas pelo alto grau de complexidade, o processo comunicativo tem como eixo central o papel desenvolvido pelos meio de comunicação social, especialmente os meios de massa, tais como a televisão, internet, jornais, revistas e rádio. Para a compreensão do significado e das consequências da teoria

\footnotetext{
${ }^{390}$ No mesmo sentido, cotejando o sistema penal construído por Jakobs com a realidade latino-americana, cf. VELÁZQUEZ VELÁZQUEZ, Fernando. El funcionalismo jakobsiano: una perspectiva latinoamericana. In.: Revista General de Derecho Penal, v. 3, 2005.
} 
da prevenção geral positiva é necessário explicitar as relações subjacentes entre o sistema penal e os meios de comunicação social.

É inegável que no âmbito da prevenção geral positiva o grau de desestabilização social dos fatos contrários à norma penal será diretamente influenciado pela visibilidade a eles atribuída por meio do processo comunicativo levado a efeito pelos instrumentos midiáticos. Conforme o que é compreendido por desestabilização social no âmbito do funcionalismo sistêmico, é inegável que apenas as condutas divulgadas (dentro do pequeno universo daquelas descobertas) pelos meios de comunicação são capazes de gerar a desestabilização social.

Todavia, tal qual a operacionalização do processo de criminalização, o funcionamento dos meios de comunicação social também é seletivo ${ }^{391}$ e sua relação com a questão criminal permite revelar uma relação mútua e intensa com o exercício do sistema punitivo. Os meios de comunicação social igualmente não funcionam de maneira neutra e objetivamente determinada pelo interesse público, senão que há diversas considerações político-ideológicas e mesmo práticas que influenciam a forma de divulgação dos fatos em forma de notícias.

A seleção entre quais fatos descobertos ensejará uma notícia depende de inúmeros fatores ou "critérios de noticiabilidade" $" 392$. Na esfera criminal, os fatos tidos como dignos de repercussão são, em geral, tanto aqueles que rompem com a normalidade, seja pelo potencial de transformar-se em escândalo, seja pelo nível de curiosidade e interesse que representam, quanto aqueles determinados por influência do poder (econômico, social ou político) ou do interesse comercial do veículo de informação, como alguma qualidade da vítima ou característica do local de ocorrência do fato. Há, por outro lado, nos meios de comunicação de massa, a composição de uma rede informativa burocratizada com repórteres especializados e informes da polícia que servem de provimento diário de casos para a pauta jornalística criminal ${ }^{393}$.

\footnotetext{
${ }^{391}$ Para uma análise crítica do papel da mídia e sua "percepção seletiva", cf. CHOMSKY, Naom. Mídia: propaganda política e manipulação. Trad. Fernando Santos. São Paulo: Editora WMF Martins Fontes, 2013, p. 47 e ss.

${ }^{392}$ BUDÓ, Marília de Nardi. Crítica à função de prevenção geral positiva da pena na interação entre mídia e sistema penal. In.: ZILIO, Jacson; BOZZA, Fábio. Estudos críticos sobre o sistema penal: homenagem ao Professor Doutor Juarez Cirino dos Santos por seu $70^{\circ}$ aniversário. Curitiba: LedZe Editora, 2012, p. 761.

393 “A própria rede informativa se encontra formada de tal maneira que normalmente há um repórter responsável por verificar os informes da polícia, as operações realizadas pela mesma, assim como as prisões efetuadas, os flagrantes e objetos apreendidos." Idem.
} 
Em maior ou menor grau, a pauta de notícias criminais dos meios de comunicação de massa são condicionadas pelo trabalho já desenvolvido pelas agências de controle social formal, ou seja, a divulgação dos fatos com repercussão criminal é uma seleção jornalística realizada a partir da seleção operacionalizada pelo processo de criminalização secundário. Se há, com efeito, critérios de seleção midiático a partir do tipo de crime ou perfil da pessoa criminalizada, tal escolha já está, em regra, predeterminada pela atuação antecedente das agências de controle formal do sistema penal.

Como a notícia criminal é predeterminada pela seleção levada a efeito pelo processo de criminalização, os meios de comunicação de massa acabam por reproduzir a questão criminal com a mesma lógica daquele processo: a divulgação incide sobre a mesma parcela de atos, como prática de uma mesma parcela da sociedade selecionada conforme as características sociais, etárias, raciais, estéticas e de gênero específicas que tornam as pessoas vulneráveis à criminalização.

Desta forma, a ligação dos meios de comunicação com o sistema penal encontra uma via de mão dupla, pois ao mesmo tempo em que sofre determinações desse sistema que resultam na forma da divulgação da pauta criminal, por outro lado contribui de maneira significativa para a formação do estigma do criminoso através dessa reprodução ${ }^{394}$, de modo a também instrumentalizar a forma de atuação das agências de controle social punitivo, afinal estas têm no estigma do delinquente um decisivo fator de criminalização. A construção social da delinquência e do delinquente tornam os meios de comunicação social em atores centrais do processo de reprodução social das desigualdades forjado pelo sistema penal ${ }^{395}$.

Ao lado da construção da imagem do delito e do delinquente, com a ocultação da cifra oculta e da seletividade do sistema penal, os meios de comunicação de massa não raro contribuem para a criação de pânicos sociais por meio da espetacularização do crime, de modo a influírem também no processo de criminalização primário, pautando a agenda

\footnotetext{
${ }^{394}$ Cf. SHECAIRA, Sérgio Salomão. A mídia e o direito penal. Boletim do Instituto Brasileiro de Ciências Criminais, v. 45, 1996.

395 “A partir dessas constatações, percebe-se que a mídia exerce papel essencial da legitimação do sistema penal, a despeito de sua patente deslegitimação teórica e fática, na medida em que procura a criminalidade nos mesmos lugares onde os agentes do sistema penal o fazem, acabando por construir uma justificativa dessa atuação, ao ocultar a cifra negra e a seletividade, ambas características que deslegitimam este sistema." BUDÓ, Marília de Nardi. Crítica à função de prevenção geral positiva da pena na interação entre mídia e sistema penal, cit., p. 763.
} 
politico-criminal ${ }^{396}$. Os medos ${ }^{397}$ coletivos aliados à sempre presente difusão do mito da insuficiência das medidas penais existentes exercem no plano político considerável influência repressiva.

Com efeito, em sociedades desiguais e conflitivas, como a brasileira, tais características serão interpretadas pela corrente inaugurada por Jakobs como uma tendência dominante de infidelidade ao direito, o que ensejaria como consequência elementar o constante recurso à utilização do sistema punitivo como forma prioritária de lidar com problemas sociais cujas raízes não estão propriamente em uma tendência de rompimento com a ordem consensualmente instituída por uma parcela da população ${ }^{398}$.

Os meios de comunicação social são, portanto, essenciais na análise da teoria da prevenção geral positiva cunhada por Jakobs, pois representam o principal instrumento comunicativo do que o autor entende por desestabilização social. O que determina a maior desestabilização social é justamente aquilo selecionado e visibilizado pelo sistema penal através do processo comunicativo levado a efeito pelos instrumentos midiáticos, ou seja, delitos e delinquentes que já se encontram arbitrariamente naturalizados no imaginário popular.

A categoria da estabilidade social, central na teoria da pena do funcionalismo sistêmico, ao aderir ao "engodo comunicacional" "399, acaba por reforçar o papel do sistema penal em um controle autoritário dos mais vulneráveis, ao mesmo tempo que fortalece a imunidade ao poder punitivo daqueles setores sociais cujas condutas puníveis não são descobertas ou divulgadas, pois não desestabilizariam a sociedade segundo seus defensores.

Assim, se o processo comunicativo é determinante para a atuação do poder punitivo segundo a teoria da pena de Jakobs, e se este mesmo processo comunicativo reproduz a

\footnotetext{
396 "Este discurso aspira a uma hegemonia, principalmente sobre o discurso acadêmico, na direção da legitimação do dogma penal como instrumento básico de compreensão dos conflitos sociais. Este discurso habilita as agências de comunicação social a pautar agências executivas do sistema penal, e mesmo a operar como elas (executivização), disputando, com vantagem, a seletividade com tais agências. A natureza real desse contubérnio é uma espécie de privatização parcial do poder punitivo, deslanchado com muito maior temibilidade por uma manchete que por uma portaria instauradora de inquérito policial." BATISTA, Nilo. Mídia e sistema penal no capitalismo tardio. Discursos Sediciosos: crime direito e sociedade, v. 12. Rio de Janeiro, 2002, p. 289.

${ }^{397}$ Cf. BATISTA, Vera Malaguti. O medo na cidade do Rio de Janeiro: dois tempo de uma história. 2. ed. Rio de Janeiro: Revan, 2003.

${ }^{398}$ Cf. FEIJOO SÁNCHEZ, Bernardo. Retribución y prevención general, cit., p. 494.

${ }^{399}$ ZAFFARONI, Eugenio Raúl; BATISTA, Nilo; ALAGIA, Alejandro; SLOKAR, Alejandro. Direito Penal Brasileiro I, cit., p. 123.
} 
forma estrutural de atuação do sistema penal, a teoria da prevenção geral positiva, portanto, atuará não apenas como um mecanismo legitimador do exercício arbitrário do poder punitivo, mas também como um verdadeiro incremento tanto do direcionamento deste poder para o controle social a partir dos crimes e criminosos expostos no processo comunicativo. Esta comunicação, outrossim, para além da criação do estereótipo do criminoso, conduz, de fato, a um reforço dos preconceitos racistas e de classe, à medida que oculta o remanescente dos ilícitos e seus autores ${ }^{400}$.

Por outro lado, diante da desestabilização social provocada pela violação da norma penal, a pena deve provocar um efeito simbólico de confiança nas normas em todos os demais indivíduos a ela submetidos. Interessa, pois, à teoria da prevenção geral positiva da pena o efeito simbólico que esta causará no conjunto social diante dos "desejos punitivos derivados da paixão coletiva" ${ }^{, 401}$.

O sujeito criminalizado é utilizado como um suporte da ação comunicativa simbólica de manutenção de confiança da norma, sendo, com efeito, instrumentalizado para atingir os fins de manutenção do sistema social. O efeito simbólico pretendido com a pena deve ser a representação da dor e do sofrimento causados por ela, de maneira a constituir uma comunicação suficiente para a reafirmação da norma e, consequentemente, da estabilidade social. O discurso penal de Jakobs, de fato, instrumentaliza o sujeito e utiliza sua dor como símbolo ${ }^{402}$ de um processo comunicativo de reprodução de desigualdade e sofrimento.

\footnotetext{
400 "Isto leva à conclusão pública de que a delinquência se restringe aos segmentos subalternos da sociedade, e este conceito acaba sendo assumido por equivocados pensamentos humanistas que afirmam serem a pobreza, a educação deficiente etc., as causas do delito, quando, na realidade, são estas, junto ao próprio sistema penal, fatores condicionantes dos ilícitos desses segmentos sociais, mas, sobretudo, de sua criminalização, ao lado da qual se espalha, impune, todo o imenso oceano de ilícitos dos outros segmentos, que os comentem com menos rudeza ou mesmo com refinamento.” ZAFFARONI, Eugenio Raúl; BATISTA, Nilo; ALAGIA, Alejandro; SLOKAR, Alejandro. Direito Penal Brasileiro I, cit., p. 48.

${ }^{401}$ BUDÓ, Marília de Nardi. Crítica à função de prevenção geral positiva da pena na interação entre mídia e sistema penal, cit., p. 758.

${ }^{402}$ ZAFFARONI, Eugenio Raúl; BATISTA, Nilo; ALAGIA, Alejandro; SLOKAR, Alejandro, op. cit., p. 123.
} 


\section{4 - Prevenção geral positiva e o significado da pena: a dor como símbolo}

Ao contrário da maioria dos autores que trabalham com a temática da pena, especialmente na perspectiva legitimadora, Jakobs é um dos raros que aborda diretamente o significado material da pena e defende que ela deve representar o que realmente significa: dor e sofrimento. Para o autor, somente a imposição da dor é capaz de resguardar cognitivamente a vigência da norma ao demonstrar o fracasso do comportamento criminoso para o objetivo de concretizar a fidelidade ao direito dos cidadãos no futuro ${ }^{403}$. Se o delito é uma forma de infidelidade jurídica, o efeito simbólico da pena como sofrimento humano é fundamental para que o desafio à norma não se torne um problema geral.

A despeito da dificuldade dos juristas de lidar com o tema da dor, seja pela complexidade de explicação de seu sentido linguístico ou mesmo sua compreensão intelectual, seja pela assepsia e neutralidade política com a qual costuma analisar o fenômeno jurídico, é inegável a necessidade de se trabalhar com as respostas que o direito deve dar diante do sofrimento humano ${ }^{404}$. Conforme destaca Antonio Madrid, o sofrimento deve ser compreendido não só em sua dimensão individual, senão também como uma construção social com dimensão política e jurídica ${ }^{405}$. Com efeito, a compreensão do direito penal não pode se materializar de maneira adequada sem o estudo de sua relação com o sofrimento humano ${ }^{406}$.

Situar o sofrimento concretamente é fundamental para ditar os rumos e decisões políticas sobre a questão. É o caso da pena ${ }^{407}$, especialmente a privativa de liberdade, que é

\footnotetext{
${ }^{403}$ JAKOBS, Günther. La pena estatal, cit., p. 142.

${ }^{404}$ Nesse sentido, Antonio Madrid adverte que o sentido da dor pode abarcar até mesmo a totalidade da condição humana. Para o autor, o sofrimento é entendido como a experiência da dor, motivo pelo qual será a expressão utilizada no presente trabalho. MADRID, Antonio. La política y la justicia del sufrimiento, cit., p. 9 e 39.

405 “A dimensão coletiva do sofrimento não corresponde à soma de sofrimentos individuais, senão à construção pública do mesmo. O sofrimento, enquanto fenômeno biológico-cultural, se situa ao mesmo tempo na dimensão pessoal e na dimensão coletiva. A experiência da dor impulsa a reflexão acerca das questões básicas da existência humana e da vida em sociedade.” ibidem, p. 33.

406 "Como explicar a relação entre o direito e as situações e estruturas que geram doença, violência, exploração ou pobreza? Aqui se sustenta que se não se compreende a relação entre o sofrimento e o direito é impossível entender o que é o direito.” ibidem, p. 12.

${ }^{407}$ A sua própria etimologia deita raízes na conjunção do poena latina, correspondente à vingança, com o pain inglês, equivalente à dor, em uma dupla valência: ativa no castigar e passiva no sofrer. Cf.
} 
um dos principais pontos de encontro entre o direito e o sofrimento. A privação da liberdade em uma instituição total ${ }^{408}$ gera a desestruturação do indivíduo no que Erving Goffman denomina de "mortificação do eu"409 a partir da adaptação ao ambiente total como o carcerário.

As características ínsitas ao ambiente prisional, como a limitação espacial, o isolamento afetivo pelo afastamento familiar e social, a falta de contato com experiências normais de $\operatorname{vida}^{410}$, a convivência forçada com pessoas não escolhidas e as relações de poder e disciplina que se estabelecem no cárcere são inegáveis fontes de sofrimento. Nesse sentido, Alessandro Baratta descreve o processo duplo de socialização ao qual a pessoa presa é submetida, que se leva a cabo pela "desculturação", que se efetua pela desadaptação às condições e circunstâncias de vida em liberdade, e pela "prisionalização", que se configura na adaptação à subcultura carcerária ${ }^{411}$.

Para além da deterioração psíquica, irreversível a longo prazo, a prisão apresenta como regra a ausência de condições ideais para uma vida saudável, o que se intensifica em países como o Brasil em que a superlotação e a inobservância das disposições normativas nacionais e internacionais sobre aprisionamento é patente, não sendo exagero afirmar que, de maneira geral, o aprisionamento no Brasil se equipara verdadeiramente à tortura ${ }^{412}$. Os riscos de deterioração da saúde, de morte por diversas causas e de abusos de toda ordem são amplamente reconhecidos pela literatura especializada ${ }^{413}$.

ZAFFARONI, Eugenio Raúl; BATISTA, Nilo; ALAGIA, Alejandro; SLOKAR, Alejandro. Direito Penal Brasileiro I, cit., p. 91.

${ }^{408}$ GOFFMAN, Erving. Manicômios, prisões e conventos, cit., p. 11.

${ }^{409}$ Cf. ibidem, p. 24 e ss.

${ }^{410}$ KARAM, Maria Lúcia. A privação de liberdade: o violento, danoso, doloroso e inútil sofrimento da pena. Rio de Janeiro: Lumen Juris, 2009, p. 16.

411 "Este (o processo de socialização) é examinado sob um duplo ponto de vista: antes de tudo, o da "desculturação", ou seja, a desadaptação às condições às condições necessárias para a vida em liberdade (diminuição da força de vontade, perda do sendo de auto-responsabilidade do ponto de vista econômico e social), a redução do senso de da realidade do mundo externo e a formação de uma imagem ilusória deste, o distanciamento progressivo dos valores e dos modelos de comportamento próprios da sociedade externa. $\mathrm{O}$ segundo ponto de vista, oposto mas complementar, é o da "aculturação" ou "prisionalização". Trata-se sa assunção das atitudes, dos modelos de comportamento, dos valores característicos da subcultura carcerária." BARATTA, Alessandro. Criminologia crítica e crítica do direito penal, cit., p. 184.

412 "As prisões serão sempre prisões; a tortura direta ou indireta, manifesta ou dissimulada, negada ou confessada faz parte da trama protetiva." TAVARES, Juarez. Mito e ideologia: objetos não manifestos no sistema penal. In.: COUTINHO, Jacinto Nelson de Miranda. Direito e Psicanálise: interseções a partir de O Senhor das Moscas de Willian Golding. Rio de Janeiro: Lumen Juris, 2011, p. 164.

${ }^{413}$ Por todos, cf. ZAFFARONI, Eugenio Raúl; BATISTA, Nilo; ALAGIA, Alejandro; SLOKAR, Alejandro. Direito Penal Brasileiro I, cit., p. 126. 
As características da pena, sejam aquelas estruturais, sejam aquelas que variam conforme as circunstâncias, conferem em maior ou menor grau um caráter aflitivo e doloroso à resposta penal. Não é por outro motivo que para Massimo Pavarini a pena é e segue sendo um sofrimento causado intencionalmente com fins de degradação ${ }^{414}$.

Se por um lado Jakobs tem o mérito de reconhecer e explicitar o sofrimento causado pela pena, o autor caminha de maneira equivocada nas respostas políticas e jurídicas dadas a este fenômeno. Na esteira do pensamento de Antonio Madrid, a luta por um mundo melhor do que o existente passa necessariamente pela redução da quantidade de sofrimento evitável que se impõe às pessoas e demanda um inconformismo político e moral frente às relações de exploração e dominação que geram sofrimento ${ }^{415}$.

As respostas jurídicas e políticas dadas ao sofrimento revelam, de fato, que as pessoas não são reconhecidas de igual forma em seu padecimento, senão que o determinante para tanto é a posição socioeconômica que ocupam em uma sociedade pautada por um modelo político e econômico que percebe as vidas como supérfluas, suprimíveis ou descartáveis ${ }^{416}$. Na mesma linha segue a pena, como um sofrimento destinado preferencialmente aos seres humanos vulneráveis ao poder punitivo, aos consumidores falhos ${ }^{417}$ descartáveis na sociedade contemporânea. A pena é, pois, um sofrimento aos que já sofrem.

A teoria da prevenção geral positiva reconhece como legítima a utilização do sofrimento humano como símbolo para a garantia de fidelidade ao direito e manutenção da ordem, de maneira a não só conferir apoio ao real processo de criminalização, mas também ao conteúdo da pena como degradação humana e imposição de sofrimento aos vulneráveis e indesejados ${ }^{418}$. Não só o processo seletivo de imposição de pena, como o próprio

\footnotetext{
${ }^{414}$ PAVARINI, Massimo. Castigar al enemigo: criminalidad, exclusión e inseguridad. Quito: FLASCO, 2009, p. 128.

415 "Também há que atrever-se a olhar a indolência com que habitualmente se trata o sofrimento alheio e frente ao qual se tenta estabelecer barreiras de proteção, já que, como se sabe, existem sofrimentos que contaminam. É preciso ampliar o terreno da política e para isso há que interrogar-se coletivamente acerca da existência social do sofrimento. Isso supõe ampliar a política como pergunta e dar resposta sobre como vivemos e como queremos viver." MADRID, Antonio. La política y la justicia del sufrimiento, cit., p. 1415.

${ }^{416}$ ibidem, p. 65-66.

${ }^{417}$ BAUMAN, Zygmunt. O mal-estar da pós-modernidade. Trad. Mauro Gama e Claudia Martinelli Gama. Rio de Janeiro: Jorge Zahar Editor, 1997, p. 57. Sobre o tema, cf. BATISTA, Vera Malaguti. O tribunal de drogas e o tigre de papel. Revista de Estudos Criminais, v.4, Porto Alegre, 2001, p. 108.

${ }^{418}$ SHECAIRA, Sérgio Salomão. Exclusão moderna e prisão antiga. In.: SÁ, Alvino Augusto de; TANGERINO, Davi de Paiva Costa; SHECAIRA, Sérgio Salomão (coord.). Criminologia no Brasil: história e aplicações clínicas e sociológicas. Rio de Janeiro: Elsevier, 2011, p. 3.
} 
conteúdo da pena na sociedade contemporânea são reafirmados e defendidos teoricamente em nome da manutenção da ordem social vigente.

Em sociedades com alto grau de conflitos sociais e de prática de crimes, tais fatos poderiam ser interpretados, segundo o funcionalismo sistêmico, como uma tendência à infidelidade ao direito ${ }^{419}$, o que demandaria maior recurso ao incremento das penas e, consequentemente, do sofrimento humano como medida naturalmente necessária ${ }^{420}$. Dentro dessa perspectiva, para além de um conjunto teórico autoritário, sua adoção como discurso legitimador da pena mostra-se especialmente perigosa em países da periferia do capitalismo.

Nesse sentido, é oportuna a advertência de Fernando Velásquez Velásquez, que descreve o denominador latino-americano de ruína política, econômica e social, que coexiste com a desigualdade, a fome e a dor da maioria da população, de modo que, ao apregoar uma eficiência acentuada, o funcionalismo sistêmico só teria lugar na América Latina como nova forma de legitimar um direito penal de emergência ${ }^{421}$.

\section{5 - Prevenção geral positiva e a realidade brasileira}

A ciência jurídico-penal alemã tem sido historicamente a principal fonte teórica de formação sistemática do direito penal brasileiro e latino-americano ${ }^{422}$. As principais construções do penalismo alemão contemporâneo encontram ampla difusão no cenário

\footnotetext{
${ }^{419} \mathrm{O}$ termo infidelidade ao direito aparece na doutrina de Jakobs de maneira notadamente aberta. A abertura conceitual empreendida por Jakobs mostra, uma vez mais, o risco de sua utilização como mecanismo de legitimação do poder punitivo, em virtude de suas possíveis consequências deletérias para a liberdade humana.

420 “A lógica da prevenção geral positiva indica que, em um sistema bastante desequilibrado devido às suas falhas, à injustiça distributiva, às carências da população, à seletividade do poder, etc., a confiança naquele (sistema) por intermédio da criminalização, exige penas eventualmente atrozes e recursos de investigação inquisitoriais, desde que proporcionem resultados nos casos que suscitam preocupação por causa de sua capacidade desequilibrante." ZAFFARONI, Eugenio Raúl; BATISTA, Nilo; ALAGIA, Alejandro; SLOKAR, Alejandro. Direito Penal Brasileiro I, cit., p. 123.

${ }^{421}$ VELÁZQUEZ VELÁZQUEZ, Fernando. El funcionalismo jakobsiano: una perspectiva latino-americana, cit., p. 20.

${ }^{422}$ Cf. ZAFFARONI, Eugenio Raúl. A ciência penal alemã e as exigências político-criminais da América Latina. Discursos Sediciosos: crime, direito e sociedade, Rio de Janeiro, v. 17/18, 2011, p. 39.
} 
jurídico brasileiro, de modo a provocar produções acadêmicas de estimável profundidade científica.

No caso do pensamento de Günther Jakobs não é diferente. A obra do autor alemão encontra ampla reprodução na América Latina, tanto pela tradução de seus trabalhos, quanto pela exposição de seu pensamento pela doutrina local. No caso da teoria da prevenção geral positiva forjada por Günther Jakobs, observa-se a exposição de sua teoria da pena nas principais obras de direito penal no Brasil ${ }^{423}$ juntamente com as clássicas teorias da pena já expostas no presente trabalho.

De uma maneira geral, a teoria da pena de Günther Jakobs é tratada no Brasil ora de maneira meramente descritiva, ora com um aspecto crítico, porém limitado à reprodução das críticas já consolidadas no ambiente da ciência penal europeia. Com efeito, a recepção das ideias produzidas no ambiente da ciência penal alemã, bem como todas as demais produzidas em uma conjuntura distinta da realidade brasileira, devem ser analisadas a partir do questionamento sobre a sua adequação ou utilidade às exigências locais $^{424}$.

A conjuntura político-social brasileira, que alia a histórica marca da exclusão, violência e extrema estratificação social com o conservadorismo e autoritarismo dos diferentes segmentos do sistema penal, demanda um específica análise da validade das construções teóricas forjadas em um ambiente sociocultural significativamente distinto do brasileiro. A vultosa experiência histórica do autoritarismo e do abuso do poder punitivo e o quadro concreto de seu exercício na contemporaneidade demandam do jurista comprometido com a democratização da sociedade a construção de um discurso de contenção do referido poder estatal, de modo que a recepção de todo arcabouço teórico no âmbito das ciências penais deve ser estudado a partir desta perspectiva ${ }^{425}$.

\footnotetext{
${ }^{423}$ BITENCOURT, Cezar Roberto. Tratado de direito penal: parte geral, v. 1. 11. ed. São Paulo: Saraiva, 2007, p. 97 e ss.; BUSATO, Paulo César. Direito penal, p. 782 e ss.; CARVALHO, Salo de. Penas e medidas de segurança no direito penal brasileiro, p. 109 e ss.; PRADO, Luiz Regis. Curso de direito penal brasileiro, volume 1: parte geral, art. $1^{\circ}$ a 120. 12. ed. São Paulo: Editora Revista dos Tribunais, 2013, p. 630 e ss.; QUEIROZ, Paulo. Direito penal, cit., p. 95 e ss.; SANTOS, Juarez Cirino dos. Direito penal: parte geral. 4. ed. Florianópolis: Conceito Editorial, 2010, p. 447 e ss.; SHECAIRA, Sérgio Salomão; CORRÊA JUNIOR, Alceu. Teoria da pena, cit., p. 132-133; ZAFFARONI, Eugenio Raúl; BATISTA, Nilo; ALAGIA, Alejandro; SLOKAR, Alejandro. Direito Penal Brasileiro I, cit., p. 121 e ss.

${ }^{424}$ Nesse sentido, cf. ZAFFANONI, Eugenio Raúl. A ciência penal alemã e as exigências político-criminais da América Latina, cit., p. 39.

${ }^{425}$ Cf. ibidem, p. 41.
} 
O filtro analítico da realidade concreta do sistema penal brasileiro não descarta, em absoluto, a adoção e aprimoramento de diversas construções jurídico-penais do direito alemão, como, por exemplo, os diversos aprimoramentos de elementos da teoria do delito que conferem maior resistência ao poder punitivo por meio da proteção da liberdade individual. Nesse sentido, a teoria penal alemã tem servido para impulsionar o aperfeiçoamento e a problematização de conceitos e regras de imputação com viés de proteção e garantia da pessoa humana ${ }^{426}$.

Por outro lado, cumpre anotar que as construções gerais de orientação do sistema penal, aquelas que constituem as bases de sustentação do poder punitivo, como a teoria da pena, não têm se mostrado adequadas para a realidade do sistema penal brasileiro na medida que em maior ou menor grau se afiguram como teorias de legitimação do poder punitivo do Estado. Com apoio na acertada metáfora de Eugênio Raúl Zaffaroni, é possível dizer que "não nos é muito útil a locomotiva, pois carecemos de trilhos, mas sim suas peças, que podemos utilizar na construção de outro engenho impulsor." ${ }^{427}$

No caso específico da teoria da prevenção geral positiva cunhada por Jakobs, o confronto com a realidade social e político-criminal brasileira desvela o particular equívoco de sua adoção ou mesmo de uma mera exposição acrítica na literatura jurídica nacional. Isso porque o modelo de sociedade do qual parte o penalista alemão não se afigura compatível com a realidade brasileira, porém encontra em certo discurso arraigado culturalmente no Brasil um terreno adequado para sua recepção.

Com efeito, as ideias centrais da prevenção geral positiva forjada a partir do funcionalismo sistêmico, como a de harmonia social, consenso acerca dos valores predominantes, estabilidade e defesa da ordem vão ao encontro de um discurso de representação da sociedade brasileira muito propício à adaptação das ideias do penalista alemão. Conforme aponta Marilena Chauí, é corrente na sociedade brasileira uma representação própria segundo a qual reina uma harmonia e união do povo brasileiro, que é

\footnotetext{
426 "Rechaçar essa experiência, o esforço intelectual e a tradição secular que a envolve, quando se pretende empreender a tarefa construtiva de um direito penal exclusivamente redutor do poder punitivo, significaria uma prodigalidade onipotente condenada ao fracasso, exposta aos riscos da insensatez intuicionista, do desmonte pelo absurdo. O direito penal redutor que renunciasse ao auxílio metodológico da dogmática se converteria num discurso político, talvez até denso, porém juridicamente deficitário. Se a tarefa do direito penal é conter e filtrar a irracionalidade e a violência do poder punitivo, as comportas do dique devem funcionar inteligentemente." ZAFFARONI, Eugenio Raúl; BATISTA, Nilo; ALAGIA, Alejandro; SLOKAR, Alejandro. Direito Penal Brasileiro II, cit., p. 25.

${ }^{427}$ ZAFFANONI, Eugenio Raúl. A ciência penal alemã e as exigências político-criminais da América Latina, cit., p. 42.
} 
naturalmente ordeiro e pacífico, sem discriminação em razão da mestiçagem, além de ser um país acolhedor e cujos contrastes representam a pluralidade e riqueza da nação. Esta mesma caracterização também permite conceber, quando conveniente, eventual divisão social ou política sob o maniqueísmo de amigos e inimigos da nação, estes último devendo ser combatidos para a conservação da unidade nacional e da harmonia da sociedade brasileira $^{428}$.

Trata-se de uma representação que é a um só tempo próxima do modelo de sociedade defendido por Jakobs e fluida a ponto de poder receber alterações e adaptações sem alteração de sua essência conservadora. A referida fluidez é a mesma que comporta "que uma sociedade que tolera a existência de milhões de crianças sem infância e que, desde seu surgimento, pratica o apartheid social possa ter de si mesma a imagem positiva de sua unidade fraterna" ${ }^{429}$ e que faz conviver no Brasil o mito de uma sociedade harmônica com uma cultura de forte caráter autoritário.

A representação tradicional da sociedade brasileira como um conjunto harmônico e ordeiro, que toma as rupturas e as formas de contestação desta ordem historicamente como inimigos da unidade nacional ${ }^{430}$, constitui terreno fértil para a difusão das ideias de Jakobs $^{431}$ dada a similaridade da representação social da qual parte o autor, bem como das consequências similares de ambos os discursos, como se pode verificar na semelhante criação de inimigos a serem combatidos diante da ameaça à ordem constituída, como fez o penalista alemão ao criar a doutrina do direito penal do inimigo.

Com efeito, o pensamento de Jakobs insere-se no contexto das ideias neoconservadoras que grassam na cultura contemporânea, cujo aspecto repressivo e de

\footnotetext{
428 “Mesmo que não contássemos com pesquisas, cada um de nós experimenta no cotidiano a forte presença de uma representação homogênea que os brasileiros possuem do país e de si mesmos. Essa representação permite, em certos momentos, crer na unidade, na identidade e na indivisibilidade da nação e do povo brasileiros, e, em outros momentos, conceber a divisão social e a divisão política sob a forma de amigos da nação e dos inimigos a combater, combate que engendrará ou conservará a unidade, a identidade e a indivisibilidade nacionais." CHAUÍ, Marilena. Brasil: mito fundador e sociedade autoritária. São Paulo: Fundação Perseu Abramo, 2012, p. 8-9.

${ }^{429}$ Cf. ibidem, p. 8.

${ }^{430}$ Vide, por exemplo, a doutrina da segurança nacional no Brasil em NETTO, José Paulo. Pequena história da ditadura brasileira (1965-1985). São Paulo: Cortez, 2014, p. 84 e ss.; Cf., ainda, sobre o chamado verdeamarelismo em CHAUÍ, Marilena, op. cit., p. 31 e ss.

${ }^{431}$ Maria Lúcia Silva Barroco igualmente alerta para o "cenário propício à objetivação de ideias e práticas neoconservadoras" no Brasil contemporâneo. BARROCO, Maria Lúcia Silva. Barbárie e neoconservadorismo: os desafios do projeto ético-político. Serviço Social \& Sociedade, v. 106, 2011, p. 211.
} 
negação do outro ${ }^{432}$ assumem uma dimensão central no enfrentamento de tensões sociais para manutenção da ordem social. Especialmente numa sociedade como a brasileira, de raízes culturais conservadoras e autoritárias, as formas de violências institucional e a questão criminal de maneira geral tendem a ser abstraídas de suas determinações sociais ${ }^{433}$.

A convivência do mito da unidade e harmonia social com a sociedade autoritária no Brasil abordado por Marilena Chauí ganha contornos específicos na esfera do sistema penal. No sistema de justiça criminal brasileiro coexistem de maneira semelhante a dualidade entre o discurso democrático e a prática autoritária ${ }^{434}$, de modo que no plano discursivo destacam-se os aportes teóricos com ênfase na garantia do cidadão frente ao poder punitivo estatal, porém no plano fático as agências penais colocam em prática as ideias destacadamente conservadoras.

Ao lado da construção teórica de uma estrutura jurídica de garantias do indivíduo, o investimento do Estado é cada vez maior em ações mais duras e repressivas que privilegiam o encarceramento ${ }^{435}$. A cultura repressiva permaneceu presente tanto na violência institucional perpetrada pelo aparelho policial, como na prática do chamado sistema de justiça criminal ${ }^{436}$.

A prática autoritária do sistema penal brasileiro não convive apenas com acepções declaradamente democráticas no plano discursivo, senão que no plano normativo a convivência igualmente resiste. Nesse sentido é marcante o fortalecimento do estado policial após o fim da ditadura civil-militar ${ }^{437}$ mesmo com o extenso rol de garantias enunciado na Constituição da República de 1988. O processo de democratização teve seu ponto de destaque com a elaboração da chamada Carta Cidadã e a considerável previsão de

432 "O neoconservadorismo busca legitimação pela repressão dos trabalhadores ou pela criminalização dos movimentos sociais, da pobreza e da militarização da vida cotidiana. Essas formas de repressão implicam violência contra o outro, e todas são mediadas moralmente, em diferentes graus, na medida em que se objetiva a negação do outro: quando o outro é discriminado lhe é negado o direito de existir como tal ou de existir com suas diferenças." ibidem, p. 209.

${ }^{433}$ Nesse sentido sobre a naturalização e despolitização da questão da violência no contexto do neoconservdorismo brasileiro, cf. BARROCO, Maria Lúcia Silva. Barbárie e neoconservadorismo, cit, $\mathrm{p}$. 208.

${ }^{434}$ Nesse sentido, cf. PASTANA, Debora Regina. Justiça penal no Brasil contemporâneo, cit., passim.

${ }^{435}$ Cf. ibidem, p. 245.

${ }^{436}$ Sobre o papel do Poder Judiciário na temática, Debora Regina Pastana aponta que "amparados pela incompreensão social de suas funções, mantêm viva a chama da autoridade e estão certos de que são os guardiões da lei e da ordem. Sob esse emblema, passam a combater a impunidade com penas severas representadas quase sempre por longas penas privativas de liberdade. Também se mostram cada vez mais coniventes com as práticas ilegais de repressão como, por exemplo, a violência policial.” ibidem, p. 247.

${ }^{437}$ Sobre a caracterização da ditadura brasileira de 1964-1985 como civil e militar, cf. NETTO, José Paulo.

Pequena história da ditadura brasileira (1965-1985), cit., p. 74. 
direitos fundamentais, dentre os quais destacam-se os direitos civis e políticos outrora cerceados, bem como diversas garantias de limitação do poder punitivo do Estado, que representaram uma clara manifestação de repúdio ao passado recente de regime de exceção e uma esperança para o futuro democrático que se esboçava ${ }^{438}$.

Não obstante, por mais paradoxal que possa parecer, o período histórico sob a vigência da atual Constituição caracterizou-se pelo incremento do estado policial, com um avançado e violento processo de encarceramento em massa ${ }^{439}$, pela piora significativa das condições materiais de aprisionamento, além da crescente prática de tortura e mortes por agentes estatais.

Outra característica da sociedade brasileira que deve ser analisada no contexto do fomento ao poder punitivo proporcionado pela teoria da prevenção geral positiva é a sua marcante verticalização. As relações hierárquicas de poder forjadas historicamente a partir do passado escravagista constituem marca fundamental da sociedade brasileira ${ }^{440} \mathrm{e}$ constituem uma mácula do ponto de vista da democratização das relações sociais. Relações verticais de mando, de ordem e desiguais, que subjugam o outro sob diversos modos de dominação, como o de classe, de gênero e o racial, por exemplo, constituem o modo histórico de relacionamento social no Brasil.

Por sua vez, Eugenio Raúl Zaffaroni aponta como principal característica do poder punitivo o seu potencial de verticalização social. O modo punitivo de enfrentamento de conflitos não é capaz de resolvê-los por essência, uma vez que se impõe como decisão vertical de poder, ao contrário de outros modelos como o reparador, por exemplo. O autor vincula o próprio surgimento do poder punitivo à hierarquização e verticalização da

\footnotetext{
${ }^{438}$ BECHARA, Ana Elisa Liberatore Silva; CACICEDO, Patrick. Sobre la situación carcelária en Brasil. Observaciones críticas, cit., p. 1-2.

${ }^{439}$ Sobre os dados do processo de encarceramento em massa brasileiro, cf. ibidem, p. 2 e ss; BATISTA, Vera Malaguti. Introdução crítica à criminologia brasileira. Rio de Janeiro: Revan, 2012, p. 99 e ss; SHECAIRA, Sérgio Salomão. Exclusão moderna e prisão antiga, cit, p. 4.

440 "Conservando as marcas da sociedade colonial escravista, ou aquilo que alguns estudiosos designam como "cultura senhorial", a sociedade brasileira é marcada pela estrutura hierárquica do espaço social que determina a forma de uma sociedade fortemente verticalizada em todos os seus aspectos: nela, as relações sociais e intersubjetivas são sempre realizadas como relação entre um superior, que manda, e um inferior, que obedece. As diferenças e assimetrias são sempre transformadas em desigualdades que reforçam a relação mando-obediência. O outro jamais é reconhecido como sujeito nem como sujeito de direitos, jamais é reconhecido como subjetividade nem como alteridade. (...) Enfim, quando a desigualdade é muito marcada, a relação social assume a forma nua de opressão física e/ou psíquica. A divisão social das classes é naturalizada por um conjunto de práticas que ocultam a determinação histórica ou material da exploração, da discriminação e da dominação, e que, imaginariamente, estruturam a sociedade sob o signo da nação una e indivisa, sobreposta como um manto protetor que recobre as divisões reais que a constituem." CHAUÍ, Marilena. Brasil, cit., p. 90.
} 
sociedade em classe ou castas, de modo a se configurar não só como uma característica de tais ambientes sociais, como também um meio necessário para a dominação social e consequente aprofundamento e manutenção dessas relações de poder ${ }^{441}$.

O inegável potencial expansionista do poder punitivo levado a efeito pela teoria da prevenção geral positiva, especialmente em contextos sociais conflitivos e desiguais como o brasileiro, impõem uma vez mais uma reflexão crítica sobre o caráter verticalizador que o discurso sobre a pena do funcionalismo sistêmico pode engendrar no contexto social da periferia do capitalismo.

As características da sociedade brasileira, portanto, exprimem a patente inadequação da adoção ou da exposição acrítica da teoria da prevenção geral positiva construída por Jakobs, seja pelo possível adaptação ao modelo representativo da sociedade como um todo harmônico, seja pela sua marca autoritária que convive com o referido discurso. A veia impulsionadora do exercício do poder punitivo pelo discurso penal do funcionalismo sistêmico, com as violentas e dolorosas consequências típicas do processo de criminalização brasileiro, bem como o viés verticalizador ínsito a este processo, recomendam uma contundente resistência a partir do paradigma crítico das ciências criminais.

\footnotetext{
${ }^{441}$ Nesse sentido, Eugenio Raúl Zaffaroni afirma ter sido o poder punitivo a chave fundamental para a colonização europeia e para a constituição e manutenção do patriarcado, sendo mesmo um poder de caráter planetário. ZAFFARONI, Eugênio Raúl. La cuestión criminal. 4. ed. Buenos Aires: Planeta, 2012, p. 31 e sS.
} 


\section{CONCLUSÃO}

1. As teorias da pena representam o alicerce dos principais discursos de legitimação do poder punitivo na modernidade, que foram consolidados historicamente tanto no pensamento penal, quanto no senso comum, como a manifestação de um bem para a vida social. As doutrinas retributivistas e preventivas formaram o principal conjunto teórico de sustentação das práticas punitivas levadas a efeito pelas agências do sistema penal, especialmente as últimas em seus discursos dissuasório e ressocializador.

2. A despeito da consolidação das clássicas teorias da pena, as críticas que sofreram, notadamente quando confrontadas com a representação da pena na realidade concreta, demonstraram a fragilidade dos referidos discursos. A naturalização das consequências deletérias da pena como fenômeno concreto e a escassa solidez fundamentadora dos discursos culminou em uma permanente crise nos discursos sobre a pena.

3. Tal qual a vertente unificadora e a teoria negativa da pena, o florescimento do funcionalismo sistêmico significou uma tentativa de solução de problemas que tinham resposta insatisfatória no curso do desenvolvimento do direito penal, especialmente a teoria da pena. A construção da teoria da prevenção geral positiva por Günther Jakobs significou uma inovação teórica cuja originalidade deve-se, essencialmente, à sua particular visão de sociedade e aos conceitos extraídos da sociologia funcionalista sistêmica.

4. O funcionalismo sociológico foi inaugurado por Émile Durkheim no contexto de consolidação da sociologia como disciplina autônoma. A adoção da epistemologia positivista que grassava naquele período é marca de sua vertente sociológica, especialmente com a utilização do método das ciências naturais, a defesa da neutralidade do pesquisador e o pressuposto de que a sociedade é regida por leis naturais invariáveis. A marca fundamental do funcionalismo é consideração da sociedade como um todo harmônico e consensual, cuja preocupação central é descobrir a funcionalidade dos fenômenos para a manutenção da harmônica ordem existente. A sociologia funcionalista, além de considerar a sociedade como um sistema harmônico, interpreta conflitos e crises sociais como manifestações de disfuncionalidade e patologia social. Para Durkheim, o 
sentido da pena seria a manutenção da coesão e harmonia social, a afirmação da consciência comum e a consequente conservação da solidariedade social.

5. A vertente sistêmica do funcionalismo de Niklas Luhmann ganhou força nas últimas décadas em diversas áreas das ciências sociais, tendo influenciado o campo jurídico de maneira considerável. Para Luhmann, a sociedade não é composta de indivíduos, mas de um conjunto de sistemas sociais específicos, com particularidades, funcionamento e lógicas de reprodução próprias. Sua preocupação central está na compreensão do funcionamento de cada sistema social autônomo e na redução da complexidade da sociedade contemporânea. Segundo tal referencial sociológico, a sociedade é um sistema autopoiético que produz seus próprios elementos, limites e estruturas, além de ser autorreferencial e fechado. O elemento fundamental da sociedade é a comunicação produzida em seu interior, motivo pelo qual o indivíduo só tem relevância para a sociedade na medida em que participe desta comunicação.

6. No âmbito da complexidade social, a busca pela ordem é o objetivo central de um sistema social, que é estudado a partir de suas funções e na medida em que tais funções contribuem para a conservação da referida ordem. O direito é um dos subsistemas sociais com as mesmas características estruturais dos demais, cujo referencial é a questão da legalidade. O processo comunicativo na sociedade produz expectativas compartidas entre os indivíduos, de modo que o direito terá como função primordial o respeito a essas expectativas vigentes. $\mathrm{O}$ direito regula os padrões de comportamento que possibilitem alguma previsibilidade de condutas como maneira de estabelecer a ordem social com redução da complexidade.

7. As normas jurídicas representam a expressão da confiança depositada em expectativas que, uma vez frustradas, acarretam a coação da norma para sua estabilização. Como o sistema do direito é fechado, a legitimidade do direito é buscada dentro do próprio sistema jurídico por meio de uma ficção legal da validade de suas normas, sem que para tanto se busque um referencial axiológico ou externo ao sistema social representado pelo direito.

8. Sob as bases do funcionalismo sistêmico, Jakobs inaugura um outro sistema de direito penal no qual procede a uma renormativização dos conceitos jurídico-penais e atribui relevância capital à ideia de manutenção da vigência da norma. Para Jakobs, interessam ao direito penal aquelas normas cuja observância geral não pode ser abandonada sob risco de erosão da configuração fundamental da sociedade. 
9. Na teoria da prevenção geral positiva, a pena aparece como uma reação contrafática à violação da norma e tem a missão de mantê-la como modelo de orientação de conduta social. A prevenção do delito por meio da pena deve garantir as condições para o convívio social harmônico e exercitar a confiança na norma, a fidelidade ao direito e a aceitação das consequências. A estabilização das expectativas normativas ocorre mediante um processo simbólico e comunicativo levado a efeito pela pena, que confirma a estrutura vigente na sociedade, cujo identidade é constituída pelas normas. Para que a pena alcance o efeito de prevenção geral positiva, no entanto, ela deve representar materialmente dor e sofrimento de modo a ser capaz de resguardar cognitivamente a vigência da norma. A prevenção geral positiva cunhada por Jakobs tem nitidamente um caráter idealista, abstrato e pretensamente neutro.

10. A escolha do funcionalismo sistêmico como referencial teórico para a construção da prevenção geral positiva revela em suas raízes não só uma específica forma de analisar a sociedade, como também uma opção política, ambas marcadas pelo conservadorismo. A chave teórica central do funcionalismo sociológico é a compreensão da ordem social e das funções que cada instituição desempenha para a sua manutenção. Desta forma, o funcionalismo representa estruturalmente um obstáculo à real compreensão dos fatores determinantes das transformações sociais, uma vez que concentra seus esforços na compreensão dos elementos que consolidam a coesão social e, naturalmente, a conservação da ordem.

11. O funcionalismo não desvela os reais fatores determinantes dos conflitos e interesses sociais, nem dos grupos sociais que representam tais interesses, de modo a ignorar uma análise crítica da sociedade, acabando por ocultar as contradições da estrutura social em benefício da entronização da ordem e da estabilidade institucional. A vertente sistêmica do funcionalismo, embora tenha modificado diversos aspectos descritivos da sociedade, não foi capaz de reverter os defeitos estruturais desta corrente da teoria social, incorrendo em semelhantes consequências de defesa da ordem social vigente.

12. As bases sociológicas e jurídico-filosóficas de Jakobs deixam transparecer a intensa relação existente entre a sua doutrina penal e a sociologia jurídica de Luhmann com o normativismo positivista de Hans Kelsen, especialmente com relação ao pressuposto da autorreferencialidade do direito e ao conceito de pessoa que adotam os autores. A ausência de referenciais externos ao direito que sirvam de parâmetro de sua legitimidade, resultam no absurdo do direito ser o seu próprio fundamento para tanto. A neutralização dos 
conflitos sociais e das relações de poder existentes na sociedade são consequências de uma concepção de direito que exclui de sua base analítica critérios externos a ele mesmo.

13. A pena como forma de manutenção do sistema social se justifica por meio de uma teoria que impõe o exercício de fidelidade ao direito sem que se possibilite o questionamento dos interesses políticos que subjazem o sistema normativo para o qual se requer a fidelidade. Com isso, resta construído um discurso penal que perfilha o normativismo e supera os limites da teoria sistêmica para se apresentar como uma técnica penal que não permite restrições ao poder punitivo. Por sua vez, a normativização do conceito de pessoa, que culmina na sua despersonalização, também é um aspecto comum aos três autores, que acabam por referendar regimes de exceção com consequências práticas na vida das não-pessoas, como o direito penal do inimigo.

14. A doutrina de Jakobs circunscreve-se ao conceito de teoria tradicional, em contraposição à teoria crítica defendida no presente trabalho, segunda a qual cumpre ao teórico analisar o existente com vistas à sua transformação, inclusive identificando os bloqueios que dificultam o melhor desenvolvimento da sociedade. Nesta seara, a tarefa do pesquisador não se resume a descrever as coisas como são, mas fundamentalmente identificar na realidade as possibilidades de sua transformação. Seus pressupostos fundamentais são a orientação para a emancipação e o comportamento crítico, entendido como o pensamento voltado para o porvir, para a transformação das situações sociais de injustiça, o que demanda o reconhecimento dos conflitos sociais a partir de divisão da sociedade entre grupos com interesses distintos e contrapostos.

15. No campo jurídico, o saber crítico destaca-se por seu objetivo de revelar as distorções entre as prescrições normativas e as relações sociais concretas, distinguindo o nível das aparências da realidade subjacente. Esta aspiração só se torna possível com o rompimento do paradigma idealista, tecnocrático e positivista por meio de um modelo crítico que adote uma racionalidade emancipatória. O direito, desta forma, deve estar relacionado sempre às suas raízes no mundo do ser para que consiga trabalhar com uma visão dinâmica e contextualizada do fenômeno jurídico, a qual possibilite a criação de uma racionalidade de defesa das necessidades humanas e direcione a práxis dos juristas positivamente diante do sofrimento humano.

16. O pensamento crítico nas ciências criminais ganhou força com a mudança do paradigma etiológico para o da reação social na criminologia, que significou uma radical transformação na maneira de analisar o fenômeno criminal, recusando o modelo de 
consenso social para destacar a dinâmica dos processos de criminalização e o papel das agências de controle social punitivo. Com o advento da criminologia crítica, os processos de criminalização passaram a ser analisados de maneira a considerar necessariamente as estruturas sociais, o contexto socioeconômico e as relações de poder no seio da sociedade capitalista, sem, contudo, abandonar a premissa da reação social.

17. A despeito de fundar sua teoria penal a partir de um referencial externo ao direito, o funcionalismo sistêmico permitiu a produção de um conhecimento juridicamente mais fechado e logicamente mais abstrato do que as produções jurídicas costumam se apresentar, o que originou diversas críticas da doutrina penal. Com efeito, a falta de suporte empírico da prevenção geral positiva, bem como seus efeitos absolutamente simbólicos, traduzem uma teoria que resulta no incremento do poder punitivo do Estado de viés notadamente autoritário.

18. O confronto da teoria da prevenção geral positiva com o real processo de criminalização expõe as inconsistências e o caráter nitidamente conservador da proposta de Jakobs. O processo de criminalização primária demonstra que é uma identidade de classe, e não a identidade da sociedade em si, que o direito penal declara proteger por meio da norma. Além disso, o processo de criminalização secundária demonstra que a teoria da pena do funcionalismo sistêmico pretende a manutenção da ordem social com a reafirmação de um pequeno conjunto de normas penais e com a imposição da pena sobre um conjunto igualmente ínfimo de pessoas especialmente vulneráveis no plano social. A prevenção geral positiva, portanto, legitima a arbitrária seletividade do sistema penal para a manutenção do status quo.

19. O caráter simbólico da teoria da pena de Jakobs confere um papel central ao processo comunicativo, especialmente aos meios de comunicação de massa. Contudo, o papel da mídia no sistema penal revela que esta reproduz a forma estrutural de atuação do sistema penal, de modo que a teoria da prevenção geral positiva atuará não apenas como um mecanismo legitimador do exercício arbitrário do poder punitivo, mas também como um verdadeiro incremento tanto do direcionamento deste poder para o controle social a partir dos crimes e criminosos expostos no processo comunicativo. Para além do reforço ao poder punitivo, a prevenção geral positiva reforma o papel da comunicação de massa na construção do estereótipo do criminoso com o consequente reforço dos preconceitos racistas e de classe, à medida que oculta o remanescente dos ilícitos e seus autores. 
20. A teoria da prevenção geral positiva reconhece como legítima a imposição do sofrimento humano como símbolo para a garantia de fidelidade ao direito, de maneira a corroborar o conteúdo da pena como degradação humana e imposição de dor aos vulneráveis. Em nome da manutenção da ordem social posta, a teoria da pena de Jakobs incrementa o sofrimento humano em um discurso sem viés crítico diante da deterioração humana. Em sociedades com alto grau de conflitos sociais e prática de crimes, tal fato é interpretado como uma tendência à infidelidade ao direito, o que ensejará maior recurso ao incremento da pena e, consequentemente, do sofrimento humano como medida preventiva, de modo que a teoria da prevenção geral positiva representa especial perigo em países da periferia do capitalismo contemporâneo.

21. A formação social brasileira revela a inadequação da adoção ou da exposição acrítica da teoria da prevenção geral positiva no espaço jurídico local. O modelo representativo da sociedade brasileira como um todo harmônico, que convive com práticas autoritárias marcantes, demonstra a especial inadequação do discurso penal sistêmico no Brasil. A tendência impulsionadora do exercício do poder punitivo pela teoria penal de Jakobs, com as violentas e dolorosas consequências do processo de criminalização, bem como o seu viés verticalizador, indicam a necessidade de uma contundente resistência a partir do paradigma crítico.

22. Ao contrário da adoção de um discurso capaz de legitimar a reprodução das desigualdades e contradições da sociedade brasileira por meio do avanço do sistema punitivo e seu violento e seletivo processo de criminalização, a conjuntura social brasileira demanda a criação de um discurso de resistência a este mesmo processo a partir das necessidades advindas das relações sociais que lhe são próprias e que caminham em sentido diametralmente oposto àquele cunhado pela teoria da prevenção geral positiva da pena de Günther Jakobs. 


\section{BIBLIOGRAFIA}

ALVES, Alaôr Caffé. Dialética e direito: linguagem, sentido e realidade. Barueri: Manole, 2010.

. Estado e ideologia: aparência e realidade. São Paulo: Brasiliense, 1987.

ANCEL, Marc. A nova defesa social: um movimento de política criminal humanista. Trad. Osvaldo Melo. Rio de Janeiro: Forense, 1979.

ANDRADE, Vera Regina Pereira de. A ilusão da segurança jurídica: do controle da violência à violência do controle penal. 2. ed. Porto Alegre: Livraria do Advogado Editora, 2003.

Sistema penal Máximo x Cidadania mínima: códigos da violência na era da globalização. Porto Alegre: Livraria do Advogado, 2003.

ANITUA, Gabriel Ignacio. Historias de los pensamientos criminológicos. Buenos Aires: Editores del Puerto, 2010.

ARNAUD, André-Jean; LOPES JR., Dalmir (orgs.). Niklas Luhmann: do sistema social à sociologia jurídica. Rio de Janeiro: Lumen Juris, 2004.

AZEVEDO, Rodrigo Ghiringheli de. Sociologia e Justiça Penal: teoria e prática da pesquisa sociocriminológica. Rio de Janeiro: Lumen Juris, 2010.

BARATTA, Alessandro. Criminologia crítica e crítica do direito penal: introdução à sociologia do direito penal. 3. ed. Trad. de Juarez Cirino dos Santos. Rio de Janeiro: Revan, 2002. 
Integración-prevención: una "nueva" fundamentación de la pena dentro de la teoría sistémica. In: BARATTA, Alessandro. Criminología y sistema penal. Compilación in memoriam. Buenos Aires: B de F, 2006.

BARCELLONA, Pietro. La teoria de sistemas y el paradigma de la sociedade moderna. Trad. de Mariano Maresca. In. Mutaciones del Leviatán. Legitimación de los nuevos modelos penales. PORTILLA CONTRERAS, Guillermo (coord.). Madrid: Akal, 2005.

Oltre lo stato sociale: economia e politica nella crisi dello Stato keynesiano. Bari: De Donato, 1980.

BARRETO, Tobias. Fundamentos do direito de punir. Revista dos Tribunais, n. 727, 1996.

BARROCO, Maria Lúcia Silva. Barbárie e neoconservadorismo: os desafios do projeto ético-político. In.: Serviço Social \& Sociedade, v. 106, 2011.

BARROS, Carmen Silvia de Moraes. A individualização da pena na execução penal. São Paulo: Editora Revista dos Tribunais, 2001.

BATISTA, Nilo. Mídia e sistema penal no capitalismo tardio. In.: Discursos Sediciosos: crime direito e sociedade, v. 12. Rio de Janeiro, 2002.

. Política criminal com derramamento de sangue. Discursos Sediciosos: crime, direito e sociedade, Rio de Janeiro, v. 5/6, 1998.

BATISTA, Vera Malaguti. Introdução crítica à criminologia brasileira. Rio de Janeiro: Revan, 2012.

O medo na cidade do Rio de Janeiro: dois tempo de uma história. 2. ed. Rio de Janeiro: Revan, 2003.

O tribunal de drogas e o tigre de papel. Revista de Estudos Criminais, v.4, Porto Alegre, 2001. 
BAUMAN, Zygmunt. O mal-estar da pós-modernidade. Trad. Mauro Gama e Claudia Martinelli Gama. Rio de Janeiro: Jorge Zahar Editor, 1997.

BECCARIA, Cesare Bonesana. Dos delitos e das penas. Trad. Lucia Guidicini e Alessandro Berti Contessa. São Paulo: Martins Fontes, 1997.

BECHARA, Ana Elisa Liberatore Silva. Bem Jurídico-Penal. São Paulo: Quartier Latin, 2014.

; CACICEDO, Patrick. Sobre la situación carcelária en Brasil. Observaciones críticas. Revista General de Derecho Penal, v. 18, 2012.

BECKER, Howard Saul. Outsiders: estudos de sociologia do desvio. Trad. Maria Luiza X. de A. Borges. Rio de Janeiro: Jorge Zahar Ed., 2008.

BITENCOURT, Cezar Roberto. Tratado de direito penal: parte geral, v. 1. 11. ed. São Paulo: Saraiva, 2007.

BITTAR, Eduardo C. B. O direito na pós-modernidade (e reflexões frankfurtianas). 2. ed. Rio de Janeiro: Forense Universitária, 2009.

BOTTOMORE, T. B. Introdução à sociologia. Trad. de Waltensir Dutra e Patrick Burglin. 9. ed. Rio de Janeiro: LTC, 2008.

BOZZA, Fábio da Silva. Teorias da pena: do discurso jurídico à crítica criminológica. Rio de Janeiro: Lumen Juris, 2013.

BUDÓ, Marília de Nardi. Crítica à função de prevenção geral positiva da pena na interação entre mídia e sistema penal. In.: ZILIO, Jacson; BOZZA, Fábio. Estudos críticos sobre o sistema penal: homenagem ao Professor Doutor Juarez Cirino dos Santos por seu $70^{\circ}$ aniversário. Curitiba: LedZe Editora, 2012.

BUSATO, Paulo César. Direito penal: parte geral. São Paulo: Atlas, 2013. 
CAMPILONGO, Celso Fernandes. Interpretação do direito e movimentos sociais. Rio de Janeiro: Elsevier, 2012.

O direito na sociedade complexa. 2. ed. São Paulo, Saraiva, 2011.

CARVALHO, Salo de. Antimanual de criminologia. 2. ed. Rio de Janeiro: Lumen Juris, 2008.

. Ensino e aprendizado das ciências criminais no século XXI. In.: Revista Brasileira de Ciências Criminais, v. 69. São Paulo: Editora Revista dos Tribunais, 2007.

. CARVALHO, Salo. O (novo) papel dos "criminólogos" na execução penal: as alterações estabelecidas pela Lei 10.792/03. In.: CARVALHO, Salo (org.). Crítica à execução penal. 2. ed. Rio de Janeiro: Lumen Juris, 2007.

Penas e medidas de segurança no direito penal brasileiro: fundamentos e aplicação judicial. São Paulo: Saraiva, 2013.

Sobre as possibilidades de uma penologia crítica: provocações criminológicas às teorias da pena na era do grande encarceramento. In.: Revista Polis e Psique, v. 3., n. 3, 2013.

- Teoria Agnóstica da Pena: entre os supérfluos fins e a limitação do poder punitivo. In.: CARVALHO, Salo de. (Org.). Crítica à execução penal. Rio de Janeiro: Lumen Juris, 2002.

CASTRO, Lola Aniyar de. Criminologia da reação social. Trad. Ester Kosovski. Rio de Janeiro: Forense, 1983.

CHAUÍ, Marilena. Brasil: mito fundador e sociedade autoritária. São Paulo: Fundação Perseu Abramo, 2012. 
CHOMSKY, Naom. Mídia: propaganda política e manipulação. Trad. Fernando Santos. São Paulo: Editora WMF Martins Fontes, 2013.

COLLINS, Randall. Quatro tradições sociológicas. Trad. de Raquel Weiss. Petrópolis: Vozes, 2009.

COMTE, Augusto. Discurso sobre o espírito positivo: ordem e progresso. Trad. Renato Barbosa Rodrigues Pereira. Porto Alegre: Globo/EDUSP, 1976.

COSTA, Helena Regina Lobo da. A dignidade humana: teorias da prevenção geral positiva. São Paulo: Editora Revista dos Tribunais, 2008.

DAVIS, Kingsley; MOORE, Wilbert. Some principles of stratification. American Sociological Review, vol. 10, n. 02, 1944.

DIAS, Jorge Figueiredo; ANDRADE, Manuel da Costa. Criminologia: o homem delinquente e a sociedade criminógena. Coimbra: Coimbra Editora, 1997.

DIETER, Maurício Stegemann. A política criminal atuarial: a Criminologia do fim da história. Rio de Janeiro: Revan, 2013.

O programa de política criminal brasileiro: funções declaradas e reais. Contribuições de Claus Offe para fundamentação da crítica criminológica à teoria jurídica das penas. Revista Eletrônica do CEJUR, v. 1, n. 2, Curitiba, 2007.

DURKHEIM, Émile. A ciência social e a ação. Trad. Inês D. Ferreira. São Paulo: Difel, 1975.

As regras do método sociológico. Trad. Paulo Neves. 3. ed. São Paulo: Martins Fontes, 2007.

Da divisão do trabalho social. Trad. Eduardo Brandão. 2. ed. São Paulo: Martins Fontes, 1999. 
. Dos Leyes de la Evolución Penal. Trad. Mónica Escayola Lara. Delito y Sociedad. Revista de Ciências Sociales. Nº 13, 1999.

FEIJOO SÁNCHEZ, Bernardo. Retribución y prevención general. Un estudio sobre la teoría de la pena y las funciones del Derecho Penal. Buenos Aires: B de F, 2007.

FERNANDES, Florestan. O método de interpretação funcionalista na sociologia. In.: Fundamentos empíricos da explicação sociológica. Companhia Editora Nacional: São Paulo, 1959.

FERRAJOLI, Luigi. Direito e razão: teoria do garantismo penal. Trad. Ana Paula Zomer Sica, Fauzi Hassan Choukr, Juarez Tavares e Luiz Flávio Gomes. 2. ed. São Paulo: Editora Revista dos Tribunais, 2006.

FERRARI, Vicenzo. Funciones del Derecho. Trad. de Maria José Añon Roig e Javier de Lucas Martin. Madrid: Editorial Debate, 1989.

FEUERBACH, Paul Johann Anselm Ritter von. Tratado de derecho penal. Trad. Eugenio Raúl Zaffaroni e Irma Hagemeier. Buenos Aires: Hammurabi, 2007.

FROMMEL, Monika. Los Orígenes ideológicos de la teoría final de la acción de Welzel. Anuario de Derecho Penal y Ciencias Penales. Fascículo II, Mayo-Agosto 1989.

GARCÍA MÉNDEZ, Emilio. Autoritarismo y control social: Argentina, Uruguay, Chile. Buenos Aires: Editorial Hammurabi, 1987.

GARCIA-PABLOS DE MOLINA, Antonio. Tratado de Criminologia. 3. ed. Valencia: Tirant lo Blanch, 2003.

GARLAND, David. A cultura do controle: crime e ordem social na sociedade contemporânea. Trad. André Nascimento. Rio de Janeiro: Revan, 2008.

Castigo y sociedad moderna: un estudio de teoría social. 2. ed. Madrid: Sigo XXI Editores, 2006. 
GINER, Salvador. Historia del pensamiento social. 12. ed. Ariel: Barcelona, 2008.

Teoría Sociológica Clásica. 3. ed. Barcelona: Ariel, 2011.

GOFFMAN, Erving. Estigma: notas sobre a manipulação da identidade deteriorada. 4. ed. Rio de Janeiro: LTC, 2008.

. Manicômios, prisões e conventos. 8. ed. Trad. Dante Moreira Leite. São Paulo: Perspectiva, 2008.

GUERRA FILHO, Willis Santiago. Autopoiese no direito na sociedade pós-moderna. Porto Alegre: Livraria do Advogado, 1997.

HASSEMER, Winfried. Introdução aos fundamentos do Direito Penal. Trad. de Pablo Rodrigo Alflen da Silva. Porto Alegre: Sergio Antonio Fabris Editor, 2005.

HEGEL, Georg Whilhelm Friedrich. Filosofia do direito. Trad. Paulo Meneses et al. São Leopoldo: Ed. UNISINOS, 2010.

HERRERA FLORES, Joaquín. 16 premisas de una teoría crítica del derecho. In.: CORREAS, Oscar; PRONER, Carol (coord.). Teoria crítica dos direitos humanos: in memoriam Joaquín Herrera Flores. Belo Horizonte: Fórum, 2011.

HORKHEIMER, Max. Teoría Tradicional y Teoría Crítica. In: HORKHEIMER, Max. Teoría Crítica. Buenos Aires. Amorrortu, 2003.

IZUZQUIZA, Ignacio. La sociedad sin hombres. Niklas Luhmann o la teoría como escándalo. 2. ed. Barcelona: Anthropos Editorial, 2008.

JAKOBS, Günther. Culpabilidad y Prevención, In.: Estudios de Derecho Penal. Trad. de Carlos J. Suárez González. Madrid: Ediciones de la Universidad Autónoma de Madrid y Editorial Civitas, 1997. 
Derecho penal: parte general. Fundamentos y teoría de la imputación. Trad. Joaquín Cuello Contreras y José Luis Serrano Gonzalez de Murillo. 2. ed. Madrid: Marcial Pons, 2003.

La pena estatal: significado y finalidad. Traducción Manuel Cancio Meliá y Bernardo Feijoo Sánchez. Madrid: Civitas, 2006.

JAKOBS, Günther, Sobre la normativización de la dogmática jurídico-penal. Trad. de Manuel Cancio Meliá e Bernardo Feijóo Sánchez. Madrid: Civitas, 2003.

. Sociedad, norma y persona en una teoría de un derecho penal funcional.

Traducción de Manuel Cancio Meliá y Bernardo Feijoo Sánchez. Madrid: Civitas, 2000.

; CANCIO MELIÁ, Manuel. Derecho penal del enemigo. Traducción Manuel Cancio Meliá. Madrid: Civitas, 2003.

JOSÉ, Caio Jesus Granduque. A construção existencial dos direitos humanos. Curitiba: CRV, 2012.

KANT, Immanuel. A metafísica dos costumes. Trad. Edson Bini. Bauru: EDIPRO, 2003.

KARAM, Maria Lúcia. A privação de liberdade: o violento, danoso, doloroso e inútil sofrimento da pena. Rio de Janeiro: Lumen Juris, 2009.

KELSEN, Hans. O que é justiça?: a justiça, o direito e a política no espelho da ciência. Trad. de Luís Carlos Borges. 3.ed. São Paulo: Martins Fontes, 2001

— Teoria geral do direito e do estado. Trad. Luís Carlos Borges. 4. ed. São Paulo: Martins Fonte, 2005

Teoria pura do direito. Trad. João Baptista Machado. 6. ed. São Paulo: Martins Fontes, 1998 
LARRAURI, Elena; CID MOLINÉ, José. Teorías Criminológicas: explicación y prevención de la delincuencia. Madrid: Bosch, 2001

LISZT, Franz von. La idea del fin en el Derecho Penal. Trad. Carlos Pérez del Valle. Granada: Ed. Comares, 1995

LOMBROSO, Cesare. O homem criminoso. 4 ed. Trad. Maria Carlota Carvalho Gomes. Rio de Janeiro: Editora Rio, 1983.

LÖWY, Michel. As aventuras de Karl Marx contra o Barão de Münchhausen: marxismo e positivismo na sociologia do conhecimento. Trad. de Juarez Guimarães e Suzane Felicie Léwy. 9. ed. São Paulo: Cortez, 2009

LUHMANN, Niklas. El derecho como un sistema social. In. GÓMEZ-JARA DÍEZ, Carlos(org.). Teoría de sistemas y derecho penal: fundamentos y posibilidades de aplicación. Bogotá: Universidad Externado de Colombia, 2007.

El derecho de la sociedade. Trad. de Javier Nafarrete. Cidade do México: Universidad Iberoamericana, 2002.

. La sociedad de la sociedad. Trad. de Javier Nafarrete. Cidade do México: Herder, 2007.

. Poder. Trad. de Luz Mónica Talbot. Barcelona: Anthropos, 1995.

. Sociedad y sistema: la ambición de la teoría. Barcelona: Ediciones Paidós, 1990.

. Sociologia do Direito I. Trad. de Gustavo Bayer. Rio de Janeiro: Tempo Universitário, 1983.

. Sociologia do Direito II. Trad. de Gustavo Bayer. Rio de Janeiro: Tempo Universitário, 1985. 
MACHADO, Antônio Alberto. Ensino jurídico e mudança social. 2. ed. São Paulo: Atlas, 2009.

MADRID, Antonio. La política y la justicia del sufrimiento. Madrid: Trotta, 2010.

MAÍLLO, Alfonso Serrano. Introdução à Criminologia. Trad. de Luiz Regis Prado. São Paulo: Editora Revista dos Tribunais, 2007.

MARX, Karl. Contribuição à crítica da economia política. Trad. Florestan Fernandes. 2. ed. São Paulo: Expressão Popular, 2008.

; ENGELS, Friedrich. A ideologia alemã. Trad. Rubens Enderle et al. São Paulo: Boitempo, 2007.

MASCARO, Alysson Leandro. Filosofia do direito. São Paulo: Atlas, 2010. . Introdução ao estudo do direito. São Paulo: Quartier Latin, 2007. . Lições de Sociologia do Direito. São Paulo: Quartier Latin, 2007.

MATOS, Olgária C. F.. A Escola de Frankfurt: luzes e sombras do Iluminismo. São Paulo: Moderna, 1993.

MATURANA, Humberto; VARELA, Francisco. A árvore do conhecimento: as bases biológicas do conhecimento humano. Trad. Jonas Pereira dos Santos. Editorial Psy II: Campinas, 1995.

MERTON, Robert K.. Teoría y estructura sociales. 4. ed. Trad. Florentino Torner e Rufina Borques. México: Fondo de Cultura Económica, 2010.

MIAILLE, Michel. Introdução crítica ao direito. Trad. Ana Prata. 3. ed. Lisboa: Estampa, 2005. 
MIR PUIG, Santiago. Función fundamentadora y función limitadora de la prevención general positiva. Anuário de Derecho Penal y Ciencias Penales, t. 39, fasc. II, Madrid.

MONTEALEGRE LYNETT, Eduardo. Estudio introductorio a la obra de Günther Jakobs. In. MONTEALEGRE LYNETT, Eduardo (coord.). EI funcionalismo en Derecho Penal: libro homenaje al Professor Günther Jakobs. Bogotá: Universidad Externado de Colombia, 2003, 2v.

MUÑOZ CONDE, Francisco; HASSEMER, Winfried. Introdução à Criminologia. Trad. de Cíntia Toledo Miranda Chaves. Rio de Janeiro: Lumen Juris, 2008.

NETTO, José Paulo. Pequena história da ditadura brasileira (1965-1985). São Paulo: Cortez, 2014.

NEVES, Marcelo. Entre Têmis e Leviatã: uma relação difícil. São Paulo: Martins Fontes, 2006.

NOBRE, Marcos. A Teoria Crítica. 2. ed. Rio de Janeiro: Jorge Zahar Ed., 2008.

OLIVEIRA JUNIOR, José Alcebíades de. Teoria jurídica e novos direitos. Rio de Janeiro: Lumen Juris, 2000.

PARSONS, Talcott. El sistema social. 2. ed. Trad. José Jiménez Blanco e José Cazorla Pérez. Madrid: Revista de Occidente, 1976.

PASTANA, Debora Regina. Justiça penal no Brasil contemporâneo: discurso democrático, prática autoritária. São Paulo: Ed. UNESP, 2010.

PAVARINI, Massimo. Castigar al enemigo: criminalidad, exclusión e inseguridad. Quito: FLASCO, 2009.

- Control y dominación: teorias criminológicas burguesas y proyecto hegemónico. 5. ed. Madrid: Siglo XXI, 1996. 
; GIAMBERARDINO, André. Teoria da pena e execução penal: uma introdução crítica. Rio de Janeiro: Lumen Juris, 2011.

PEÑARANDA RAMOS, Enrique; SUÁREZ GONZÁLEZ, Carlos; CANCIO MELIÁ, Manuel. Um Novo Sistema do Direito Penal. Considerações sobre a teoria da imputação objetiva de Günther Jakobs. Trad. de André Luís Callegari e Nereu José Giacomolli. 2. ed. Porto Alegre: Livraria do Advogado Editora, 2013.

PORTILLA CONTRERAS, Guillermo. Los excesos del formalismo jurídico neofuncionalista en el normativismo del Derecho penal. In.: PORTILLA CONTRERAS, Guillermo (coord.). Mutaciones de Leviatán: legitimación de los nuevos modelos penales. Madrid: Akal, 2005.

POSSAS, Mariana Thorstensen. O problema da inovação da teoria da prevenção geral positiva. Revista Brasileira de Ciências Criminais, vol. 56, São Paulo: Editora Revista dos Tribunais, 2005.

PRADO, Luiz Regis. Curso de direito penal brasileiro, volume 1: parte geral, art. $1^{\circ}$ a 120. 12. ed. São Paulo: Editora Revista dos Tribunais, 2013.

QUEIROZ, Paulo. Direito penal: parte geral. 5. ed. Rio de Janeiro: Lumen Juris, 2009.

RITZER, George. Teoría Sociológica Moderna. 5. ed. Trad. de Maria Teresa Casado Rodríguez. Madrid: McGraw-Hill, 2010.

ROCHA, Leonel Severo; SCHWARTZ, Germano; CLAM, Jean (orgs.). Introdução à teoria do sistema autopoiético do direito. Porto Alegre: Livraria do Advogado, 2005.

ROXIN, Claus. Derecho penal: parte general. Tomo I. Fundamentos. La estructura de la teoría del delito. Trad. Diego-Manuel Luzón Peña et al. 2. ed. Madrid: Civitas, 2003.

Política criminal e sistema jurídico-penal. Trad. Luís Greco. Rio de Janeiro: Renovar, 2002. 
Prevención y determinación de la pena. Trad. de Francisco Munñoz Conde. Doctrina Penal, Año 3, nº 9-12, Buenos Aires: Depalma, 1980.

Problemas fundamentais de Direito Penal. 2. ed. Lisboa: Vega, 1998.

RUSCHE, Georg; KIRCHHEIMER, Otto. Punição e estrutura social. 2. ed. Rio de Janeiro: Revan, 2004.

SABADELL, Ana Lúcia. Manual de sociologia jurídica: introdução a uma leitura externa do direito. 4. ed. São Paulo: Editora Revista dos Tribunais, 2008.

SAlVADOR NETTO, Alamiro Velludo. Finalidades da Pena. Conceito Material de Delito e Sistema Penal Integral. São Paulo: Quartier Latin, 2009.

SANTOS, Juarez Cirino dos. A criminologia radical. 3. ed. Curitiba: ICPC: Lumen Juris, 2008.

. Direito penal: parte geral. 4. ed. Florianópolis: Conceito Editorial, 2010.

. Direito penal do inimigo - ou o discurso do direito penal desigual. Disponível em http://icpc.org.br/artigos/ .

- Teoria da pena: fundamentos políticos e aplicação judicial. Curitiba: ICPC; Lumen Juris, 2005.

SELL, Carlos Eduardo. Sociologia Clássica: Marx, Durkheim e Weber. Petrópolis: Vozes, 2009.

SHECAIRA, Sérgio Salomão. A mídia e o direito penal. Boletim do Instituto Brasileiro de Ciências Criminais, v. 45, 1996.

Criminologia. $2^{\circ}$ ed. São Paulo: Editora Revista dos Tribunais, 2009. 
Exclusão moderna e prisão antiga. In.: SÁ, Alvino Augusto de; TANGERINO, Davi de Paiva Costa; SHECAIRA, Sérgio Salomão (coord.). Criminologia no Brasil: história e aplicações clínicas e sociológicas. Rio de Janeiro: Elsevier, 2011.

; CORREAA JUNIOR, Alceu. Teoria da pena: finalidades, direito positivo, jurisprudência e outros estudos de ciência criminal. São Paulo: Editora Revista dos Tribunais, 2002.

SILVA SÁNCHEZ, Jesús Maria. Aproximación al Derecho Penal contemporâneo. 2. ed. Buenos Aires: B de F, 2010

SORIANO, Ramón. Sociología del derecho. Barcelona: Ariel, 1997.

TAVARES, Juarez. Mito e ideologia: objetos não manifestos no sistema penal. In.: COUTINHO, Jacinto Nelson de Miranda. Direito e Psicanálise: interseções a partir de O Senhor das Moscas de Willian Golding. Rio de Janeiro: Lumen Juris, 2011.

. Teoria do Injusto Penal. 3. ed. Belo Horizonte: Del Rey, 2003.

Teoria dos crimes omissivos. São Paulo: Marcial Pons, 2012.

TAYLOR, Ian; WALTON, Paul; YOUNG, Jock (org.). Criminologia crítica. Trad. Juarez Cirino dos Santos e Sergio Tancredo. Rio de Janeiro: Edições Graal, 1980.

; WALTON, Paul; YOUNG, Jock. La nueva criminologia: contribución a una teoría social de la conducta desviada. 3. ed. Trad. Adolfo Crosa. Buenos Aires: Amorrortu, 2007.

TRINDADE, André. Para entender Luhmann e o direito como sistema autopoiético. Porto Alegre: Livraria do Advogado, 2007.

VELÁZQUEZ VELÁZQUEZ, Fernando. El funcionalismo jakobsiano: una perspectiva latinoamericana. Revista General de Derecho Penal, v. 3, 2005. 
VILLAS-BÔAS FILHO, Orlando. O direito na teoria dos sistemas de Niklas Luhmann. São Paulo: Max Limonad, 2006.

VILLAS-BÔAS FILHO, Orlando. Teoria dos sistemas e o direito brasileiro. São Paulo: Saraiva, 2009.

WELZEL, Hans. Derecho Penal Alemán. Parte General. $11^{\circ}$ ed. Trad. Juan Bustos Ramírez e Sérgio Yáñez Pérez. Santiago de Chile: Editorial Jurídica de Chile, 1970.

YAROCHEWSKY, Leonardo Isaac. A influência da teoria dos sistemas de Niklas Luhmann na teoria da pena. Ciências Penais, Revista da Associação Brasileira de Professores de Ciências Penais, Ano 1, n. 0, 2004.

ZAFFARONI, Eugênio Raúl. A ciência penal alemã e as exigências político-criminais da América Latina. Discursos Sediciosos: crime, direito e sociedade, Rio de Janeiro, v. 17/18, 2011.

. Em busca das penas perdidas: a perda de legitimidade do sistema penal. Trad. Vânia Romano Pedrosa e Almir Lopes da Conceição. 5.ed. Rio de Janeiro: Revan, 2001.

La cuestión criminal. 4. ed. Buenos Aires: Planeta, 2012.

. O inimigo no direito penal. Trad. Sérgio Lamarão. 2 ed. Rio de Janeiro: Revan, 2007.

; ALAGIA, Alejandro; SLOKAR, Alejandro. Derecho penal: parte general. 2. ed. Buenos Aires: Ediar, 2002.

; BATISTA, Nilo; ALAGIA, Alejandro; SLOKAR, Alejandro. Direito Penal Brasileiro I. Rio de Janeiro: Revan, 2003.

; BATISTA, Nilo; AlagiA, Alejandro; SLOKAR, Alejandro. Direito Penal Brasileiro II. Rio de Janeiro: Revan, 2010. 
ZILIO, Jacson Luiz. La criminología crítica como (de) construcción del derecho penal. Revista Holística Jurídica. v. 8. Medellín: Universidad de San Buenaventura, 2010. 